\title{
In the Wake of Change:





\section{In the Wake of Change: \\ An Urban Design Response to Rising Sea Levels in Wellington City}

SUBMITTED IN FULFILMENT OF THE REQUIREMENTS OF THE DEGREE

MASTER OF ARCHITECTURE (MARCH[PROF])

DECEMBER 2010

FACULTY OF ARCHITECTURE AND DESIGN

VICTORIA UNIVERSITY OF WELLINGTON 

This thesis focuses on possible urban design responses to a worst-case scenario for sea level change: a rise of one metre by the year 2100. Wellington City is comparable to many coastal cities around the world; much of the city sits on lowlying reclaimed land. A rise in sea level of one metre could result in extensive damage to buildings and infrastructure.

Scientists predict that seas will rise somewhere between $0.18 \mathrm{~m}$ and $1.2 \mathrm{~m}$ by the end of the century. New Zealand's Ministry for the Environment advises local bodies to plan for a rise in sea level of at least $0.8 \mathrm{~m}$ by the year 2090 . Wellington City Council has begun to research the possible effects of sea level rise on the city but has not yet seriously considered design options in response to this. The uncertainties regarding the extent of sea level rise mean its impact on Wellington City could be minimal $(0.5 \mathrm{~m}$ rise) or extensive ( $1.5 \mathrm{~m}$ rise).

Dykes, sea walls and levees have been constructed for centuries to protect local populations. These can be detrimental to urban quality, and can impede the connections between cities and their waterfronts. Up until now, their effects on overall urban design have rarely been considered. Urban designs adopted internationally for flood defence were reviewed with regard to Wellington City's needs.

A mapping study of three possible scenarios $(0.5 \mathrm{~m}, 1.0 \mathrm{~m}, 1.5 \mathrm{~m})$ for sea level change in Wellington City has been made, including assessment with respect to urban design principles.

This thesis concludes by offering a realistic response to the one metre scenario. Three sections of the city are developed further to demonstrate how a unified response could be developed throughout the city.

The chosen response to the problem of sea level rise in Wellington City seeks to preserve sense of place while introducing new urban design concepts. The chosen design uses a sea wall to protect the existing city against a one-metre rise in sea level, and creates an amphibious zone on its seaward side.

The sea wall sits inside the city rather than around it. As well as forming a boundary, it is a public structure offering visual connections between city and sea, and maintaining the essential character of the waterfront.

The amphibious zone is designed to withstand flooding during storms and high sea surges. Design in this zone includes new building processes that adapt with sea level changes. 

Contents

List of figures and tables

Acknowledgements

Xiii

Chapter One: Introduction

Thesis questions and aims

1.2 Site: Wellington Central Business District 4

1.3 Chapter outlines 5

Chapter Two: International review 8

2.1 Sea level rise predictions 8

$2.2 \quad$ Consequences of sea level rise 10

$\begin{array}{lll}2.3 & \text { Current world projects } & 11 \\ 2.4 & 12\end{array}$

Chapter Three: Urban design theory $\quad 16$

3.1 Defining urban design 16

3.2 Good public space 16

3.3 Urban design theory on successful waterfronts 19

3.4 Good urban design through process and implementation 20

3.5 Discussion 21

Chapter Four: Case studies $\quad 24$

$\begin{array}{cll}4.1 & \text { Protect } & 26 \\ 4.1 .1 & \text { Thames Estuary Project, London } & 26 \\ 4.1 .2 & \text { Clevely's Sea Wall, Lancashire } & 27 \\ 4.1 .3 & \text { Discussion } & 28 \\ 4.2 & \text { Accomodate } & 29 \\ 4.2 .1 & \text { 'New Water' floating buildings, The Netherlands } & 29 \\ 4.2 .2 & \text { 'Amphibious Homes' Maasbommel, The Netherlands } & 30 \\ 4.2 .3 & \text { Discussion } & 31 \\ 4.3 & \text { Retreat } & 32 \\ 4.3 .1 & \text { Byron Bay, NSW, Australia } & 32 \\ 4.3 .2 & \text { Waitakere riverside relocation project, Auckland } & 33 \\ 4.3 .3 & \text { Discussion } & 34 \\ 4.4 & \text { Conclusion } & 35\end{array}$


Chapter Five: Wellington

5.1.1 The seaside and coast: kiwi culture and legislation

5.1.2 Wellington harbour's history

5.1.3 Design directive and legislation in Wellington City

5.2 Sea level rise

5.2.1 Predictions for Wellington

5.2.2 Legislation commitment to sea level rise

5.3 Urban assessment

5.3.1 Central city

5.3.2 Waterfront

5.3.3 Greater context: flooding hazards

Chapter Six: Mapping Studies

6.1 Sea level rise scenarios

6.1.1 Scenario 1:0.5m sea level rise

6.1.2 Scenario 2: $1.0 \mathrm{~m}$ sea level rise

6.1.3 Scenario $3: 1.5 \mathrm{~m}$ sea level rise

6.2 Further analysis of Scenario 2: $1 \mathrm{~m}$ sea level rise

6.3 Discussion

\section{Chapter Seven: Design}

$7.1 \quad$ Design process

7.1.1 Main objectives

7.1.2 Design development

7.2 Design overview

7.2.1 The sea wall

7.2.2 The amphibious zone

7.3 Developed Design

7.3.1 Slice 1: Kumutoto Precinct

7.3.2 Slice 2: Frank Kitts Park

7.3.3 Slice 3: Waitangi Park 


\section{Appendix}

Two: Expanded Polystyrene (EPS)

136

Three: Geoflex Vinyl Sheet Pile System

Four: Floodgates 

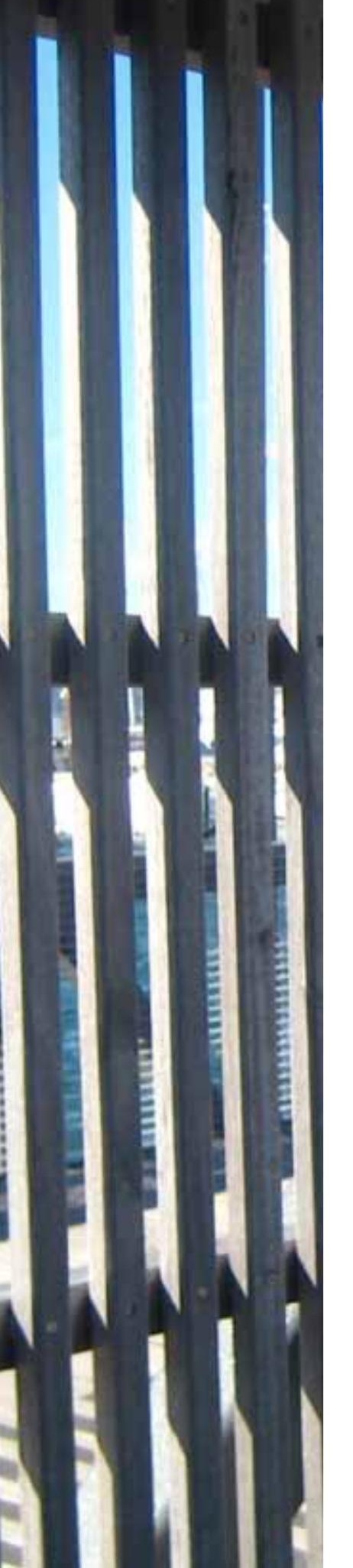


\section{List of figures and tables}

\section{FIGURES}

\section{Cover}

[one-metre contour data Wellington City from GIS Team at Wellington City Council]. (April 2010).

All other figures before chapter one

[Author's own]. (2010). Wellington.

Figure 1.1: Study site: Wellington Central City

[Aerial Photographs of Wellington Waterfront Ltd.]. (November 2006). Wellington Waterfront Ltd. Private collection, Wellington, Reproduced with permission from Welington Waterfront Ltd

Figure 1.2: Study site boundaries: Wellington Central City

[Satellite Image from Wellington City Council]. (June 2010) Wellington City Counci Reproduced with permission from Wellington City Council

\section{Figure 2.1: Predictions of global sea level rise to the mid 2090}

[Graph produced by the Ministry for the Environment NZ] (July 2008). A Guidance Manual for Local Government in New Zealand. 2nd edition. Revised by Ramsay, D, and Bell, R. (NIWA). Prepared for Ministry for the Environment. viii+127 p.24

Figure 2.2: Coastal Erosion of Waihi Beach, Coromandel Peninsula, New Zealand [Author's own photograph]. (August 2010). Waihi Beach, New Zealand.

\section{Figure 2.3: MoMA Exhibition: Rising Currents}

[Rising Currents Project Images: Architecture Research Office and Dlandstudio].

(September 2010). Retrieved from Rising Currents: http://www.moma.org/explore/ inside_out/2010/09/21/rising-currents-transformation-through-creative-collaboration

\section{Figure 2.4: Wellington Waterfront and Civic Square}

[Aerial Photographs of Wellington Waterfront Ltd.]. (November 2006). Wellington Waterfront Ltd. Private collection, Wellington, Reproduced with permission from Welington Waterfront Ltd

Figure 3.1: Port Luis Waterfront, Mauritius Island

[Figure from Wikipedia Commons] (2010) Retrieved from:

http://commons.wikimedia.org/wiki/File:Mauritius 23.08.2009 13-56-13.jpg

\section{Figure 3.2: Thames Gateway Design Pact}

[Figure from CABE website] (2006) Retrieved from:

http://www.cabe.org.uk/files/love-to-live.pdf

\section{Figures $3.3 a+b$ : Battery Park City Masterplan}

Lang, J. (2005). Urban Design: A typology of procedures and products. Burlington: Architectural Press. p.242.

\section{Figure 4.1a: Protect}

[Figure from Cleveley's Sea Wall website]. (2008). Retrieved from:

http://www.cleveleys-seawall.co.uk/Reports/p_10-19-cleveley1 V32.pdf

\section{Figure 4.1b: Accommodate}

[Visualisation of Citadel, from Insidelux.com] (2009) Retrieved from:

http://www.insidelux.com/2009/09/03/europe-to-get-its-first-floating-apartmentcomplex/

\section{Figure 4.1c: Retreat}

[Figure from report: Working together for Healthy Streams and Strong Communities available on Waitakere City Council Website]. (2007). p.10. Retrieved from: www.riversymposium.com/2007_Presentations/C3D_Twin\%20Steams.pd

Figure 4.2: Thames Estuary Barrier

(2004) Retrieved from:

http://www.geograph.org.uk/photo/175396

\section{Figure 4.3: Cleveley's Sea Wall}

[Figures from Cleveley's Sea Wall website]. (2008). Retrieved from:

http://www cleveleys-seawall.co.uk/Reports/P_10-19-cleveley] v32.pdf

Figure 4.4: Sea Wall in Southampton, Britain

Anderson, W. (2009). Homes for a Changing Climate: Adopting our homes and communities to cope with the climate of the 21 st century. Totnes: Green Books. p.66.

Figure 4.5: Amphibious houses, Maasbommel, Netherlands [Figures from Marketplace website] (2010). Retrieved from:

http://marketplace publicradio.org/standard/display/slideshow.php? $\mathrm{ftr}$ id=43925

\section{Figure 4.6: Amphibious house floating foundation, Maasbommel, Netherlands} [Image from Marketplace website] (2010). Retrieved from:

http://marketplace publicradio.org/standard/display/slideshow. php?ftr id $=43925 \&$ slide $=3$

\section{Figure 4.7: New Water}

[Image from Waterstudio website] (2010). Retrieved from:

http://www.waterstudio.nl/en/projects/47_ps_New\%20water.html

Figure 4.8: Citadel

[Image from Waterstudio website] (2010). Retrieved from:

http://www waterstudio nl/en/projects/54 pa The\%20Citadel.htm

\section{Figure 4.9: Floating EcoCity, Netherlands}

[Image from Urgenda website] (2010). Retrieved from:

www.urgenda.nl/.../Prospectus\%20Floating\%20EcoCity\%20ENG.pdf

\section{Figure 4.10: Byron Bay, Australia}

[Image from Sydney Morning Herald website] (2009). Retrieved from:

http://www.smh.com.au/opinion/blogs/climate-run/sea-level-rules-need-to-go-

further-mayor/20091 11 3-id2e.html

Figure 4.11: Project Twin Streams: Key objectives, the 'Nine Clouds'

[Photograph from report: Working together for Healthy Streams and Strong Communities available on Waitakere City Council Website]. (2007). p.24. Retrieved from:

www riversymposium com/2007 Presentations/C3D Twin\%20Steams.pdf 
Figure 4.12: Waitakere's new cycle and walkway

[Photograph from report: Working together for Healthy Streams and Strong Communities available on Waitakere City Council Website]. (2007). p.43. Retrieved from:

www.riversymposium.com/2007_Presentations/C3D_Twin\%20Steams.pdf

\section{Figure 4.13: Community planting days}

[Photograph from report: Working together for Healthy Streams and Strong Communities available on Waitakere City Council Website]. (2007). p.33. Retrieved from: www.riversymposium.com/2007_Presentations/C3D_Twin\%20Steams.pd

\section{Figure 4.14: Communication and relationship development}

[Photograph from report: Working together for Healthy Streams and Strong Communities available on Waitakere City Council Website]. (2007). p.14. Retrieved from:

www.riversymposium.com/2007_Presentations/C3D_iwin\%20steams.pd

\section{Figure 4.15: An existing sea wall at Oriental Bay, Wellington}

Author's own photograph]. (May 2010). Oriental Bay, Wellington,

Figure 5.1: Hikoi protest march outside House of Parliament, Wellington

[Photograph of Hikoi from Absolute Astonomy]. (2004). Retrieved from http://www. absoluteastronomy.com/topics/Maori_protest_movement

\section{Figure 5.2a: 1860}

Photograph part of Turnbull Library Pictures]. (1860). Overlooking Te Aro flat, Wellington. Timeframes online database (ID: PFP-022077), Alexander Turnbull Library, Wellington, NZ. Reproduced with permission from Alexander Turnbull Library.

\section{Figure 5.2b: 1920s}

[Photograph part of Highe, Leslie, 1898 -1942: Collections of photographic prints and negatives]. (1920s) Aerial view of Wellington. Timeframes online database (ID: PFPP014750), Alexander Turnbull Library, Wellington, NZ. Reproduced with permission from Alexander Turnbull Library.

\section{Figure 5.2c: ca. 1937}

Photograph part of Original photographic prints and postcards from file print collecfion, Box 13]. (ca. 1937). Aerial view of Wellington city and harbour. Timeframes online database (ID: PFP-021283), Alexander Turnbull Library, Wellington, NZ. Reproduced with permission from Alexander Turnbull Library.

\section{Figure 5.2d: 1953}

[Photograph part of Whites Aviation Ltd: Photographs]. (August 1953). Wellington. Timeframes online database (ID: PA-Group-00080), Alexander Turnbull Library, Wellington, NZ. Reproduced with permission from Alexander Turnbull Library.

\section{Figure 5.2e: 198}

Photograph part of The Dominion Post: Photographic negatives and prints of the Evening Post and Dominion newspapers]. (August 1953). Wellington. Timeframes online database (ID: PAColl-7327), Alexander Turnbull Library, Wellington, NZ. Reproduced with permission from Alexander Turnbull Library.

\section{Figure 5.2f: 2006}

[Aerial Photographs of Wellington Waterfront Ltd.] (November 2006). Wellington Waterfront $L$ td. Private collection, Wellington, Reproduced with permission from Wellington Waterfront Ltd
Figure 5.3: Sea wall plan 1917

[Plan by Howorth, C.R. Property of Wellington Waterfront Ltd.] (May 1917). T. No 878: W. H. B Plan Showing Walls, Wharfs, and Breastworks in Lambton Harbour. Port of Wetlington. Wellington Waterfront Ltd. private collection, Wellington, NZ.

Figure 5.4: Wellington waterfront reclamations

Author's own. [Information gathered from Wellington Waterfront Ltd. Historical maps]

\section{Figure 5.5: One metre sea level rise visualisation}

GIS image from Dominion Post article]. (December 2009). Retrieved from

http://www.stuff.co.nz/science/3129374/Wellington-could-be-more-like-Veniceby-2100. Dominion Post Article: 'Wellington could be more like Venice by 2100' Emily Watt.

\section{Figure 5.6: Civic Square, Wellington}

[Author's own photograph]. (February 2010). Wellington.

Figure 5.7: Central City and Waterfront Areas

[Author's own analysis]. Original map supplied by GIS team of Wellington City Council (April 2010)

\section{Figures 5.8, 5.9: a,b,c,d,e,f Successful urban spaces along the waterfront} [All author's own photographs]. (2010). Wellington.

\section{Figures 5.10: Area under threat due to flood hazards}

[Author's own mapping study]. (2010).

[Data supplied by Wellington City Council]. (2009).

R. LeBlanc. Updated by Wellington City Council, Infrastructure Planning \& Data.

\section{Figures 5.11: Area under threat due to tsunami risk}

[Author's own mapping study]. (2010).

[Data supplied by Wellington City Council]. (June 1990, updated in 2000).

Created by Wane Hastie and Andrew Harrington of the Wellington Regional Council

Figures 6.1 6.2, 6.3, 6.4: Sea level rise visualisations and maps: Wellington City Council [Wellington Central City sea level rise scenario: $1.0 \mathrm{~m}$ sea level rise]. (April 2010). Prepared for the author and reproduced with permission from Wellington City Council. Property boundaries Land Information NZ Licence WN0853547/2 CROWN COPYRIGHT RESERVED. Accuracy in urban areas: +/-1m, Accuracy in rural areas: +/-30m. Topographic data: Wellington City Council WCC copyright reserved Accuracy: $+/-30 \mathrm{~cm}$. Any contours displayed are only approximate and must not be used for detailed Any contous displayed are only approximate and nust not be uccuracy: 1 - $30 \mathrm{~cm}$. c variety of sources and its accuracy may vary.

\section{Figure 6.5: One-metre contours}

[Author's own mapping studies overlayed with Wellington City Council one metre sea level rise visualisation]. (2010).

[one-metre contour data from Gis Team at Wellington City Council]. (April 2010).

\section{Figure 6.6: Flooding hazards}

Author's own mapping studies overlayed with Wellington City Council one metre sea level rise visualisation]. (2010).

[Flood hazard area supplied by Wellington City Council]. (2009).

R. LeBlanc. Updated by Wellington City Council, Infrastructure Planning \& Data. 
Figure 6.7: Main Vehicular routes

[Author's own mapping studies overlayed with Wellington City Council one metre sea level rise visualisation]. (2010).

\section{Figure 6.8: Main pedestrian routes}

[Author's own mapping studies overlayed with Wellington City Council one metre sea level rise visualisation]. (2010).

[Golden mile data from Wellington City Council Website] (2010) Retrieved from:

http://www.wellington.govt.nz/projects/new/goldenmile/goldenmile.html

\section{Figure 6.9: Buildings Affected}

[Author's own mapping studies overlayed with Wellington City Council one metre sea level rise visualisation]. (2010).

\section{Figure 6.10: Heritage Buildings and areas}

Author's own mapping studies overlayed with Wellington City Council one metre sea level rise visualisation]. (2010).

[Heritage buildings data from Wellington City Council District Plan]. (2010). Retrieved from:

http://www.wellington.govt.nz/services/heritage/inventory/index.htm

\section{Figure 6.11: Urban streams}

[Author's own mapping studies overlayed with Wellington City Council one metre sea level rise visualisation]. (2010).

[Data on Old streams from Wellington City Council]. Old Streams as shown in Mein Smith Survey (1840).

[Data on stormwater pipes supplied by GIS team of Wellington City Council]. (April 2010)

\section{Figure 6.12: Infrastructure}

[Author's own mapping studies overlayed with Wellington City Council one metre sea level rise visualisation]. (2010)

[Data on stormwate, sewage and water netowks supplied by GIS team of Wellington City Council]. (April 2010).

\section{Figure 6.13: Parcel boundaries}

[Author's own mapping studies overlayed with Wellington City Council one metre sea level rise visualisation]. (2010).

[Data on parcel boundaries supplied by GIS team of Wellington City Councill. (April 2010)

\section{Figure 6.14: Public space}

[Author's own mapping studies overlayed with Wellington City Council one metre sea level rise visualisation]. (2010).

\section{Figure 6.15: Waterfront sculpture}

[Author's own photograph]. (April 2010). Wellington.

Figure 7.1, 7,2, 7.3, 7.4, 7.5, 7.6, 7.7, 7.8: Design Images

[All Author's own renderings + maps]. (2010).

Figures 7.9: Wall materials

[Author's own photographs]. (2010). Wellington
Figures $7.10,7.11,7.12,7.13,7.14,7.15$ : Design Images

[Author's own renderings + maps]. (2010).

Figure 7.16: Aerial image: Kumutoto Precinct

[Aerial Photographs of Wellington Waterfront Ltd.]. (November 2006). Wellington

Private collection, Wellington, Reproduced with permission from Wellington Waterfront Ltd

Figures 7.17, 7.22, 7.24: Site photos: Kumutoto Precinct

[Author's own photos]. (2010). Wellington.

Figures 7.18, 7.19, 7.20, 7.21, 7.22, 7.23, 7.24, 7.25, 7.26: Kumutoto Precinct Design [Author's own renderings + maps]. (2010).

Figure 7.27: Aerial image: Frank Kitts Park

[Aerial Photographs of Wellington Waterfront Ltd.]. (November 2006). Wellington

Private collection, Wellington, Reproduced with permission from Wellington Waterfront Ltd

Figures 7.28 7.31: Site photos: Frank Kitts Park

[Author's own photos]. (2010). Wellington.

\section{Figures $7.29,7.30,7.32,7.33,7.34,7.35$ : Design: Frank Kitts Park}

[Author's own]. (2010).

Figure 7.36: Aerial image: Waitangi Park

[Aerial Photographs of Wellington Waterfront Ltd.]. (November 2006). Wellington Waterfront Ltd.

Private collection, Wellington, Reproduced with permission from Wellington Waterfront Ltd

Figures 7.37, 7.40, 7.43, 7.45: Site photos: Waitangi Park

[Author's own photos]. (2010). Wellington.

\section{Figures 7.38, 7.39, 7.41, 7.42, 7.44, 7.46: Design: Waitangi Park}

[Author's own]. (2010).

Figure 9.1: Design: south view

[Author's own]. (2010). 


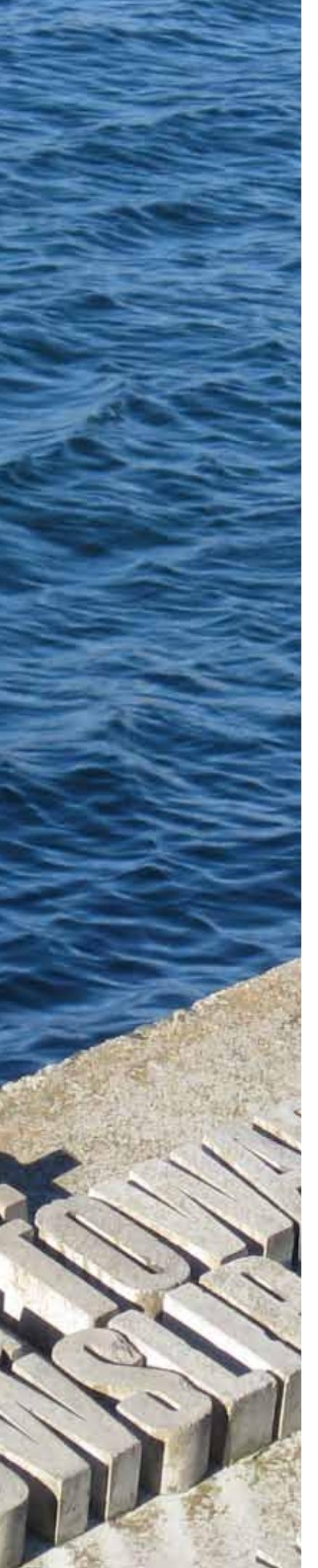


I wish to thank the School of Architecture and Design at Victoria University of Wellington for the high-quality education and support I have received during the last five years. Throughout this year I have had much support from various tutors and lecturers - from several disciplines. They have helped me consider a wide range of design options.

I am especially indebted to Chris McDonald, my supervisor and coordinator of the Masters programme, who has constantly encouraged and supported me. He spent countless hours reading my thoughts, and assessing my designs. I will never forget the day 7,000 words of jumble were returned within hours with detailed his comments. Thank you for giving me latitude to explore the topic in my own way while constantly providing encouragement, advice and guidance.

I would not have made much progress without the help of several individuals at Wellington City Council. Thank you Nenad Petrovic, of the GIS team, for hours of work with the LiDAR data to produce the most accurate analysis I could have imagined of Sea Level Rise of Wellington City. Without which I would have never been able to assess this situation realistically. Thank you to Clay Johnsen, David Bullpitt and Hasith Gamage of the Urban Design team. And thanks Chris Cameron, Paul Kos and Zach Rissel from the Climate Change department, for your encouragement and suggestions.

Thank you to John Tiller, from Wellington Waterfront Ltd., who on various occasions supplied me with invaluable information about the Wellington Waterfront. Thank you to Julie King and Warren Gray, from the Ministry of Environment, who took my idea so seriously, and were encouraging and enthusiastic. Thanks to Bill Arnold, principal engineer of Capacity Design, for an incredible amount of help regarding sea wall and storm water design. Thanks also for your interest and enthusiasm.

I have been lucky to be surrounded by intelligent, humorous and inspiring classmates. After five years together we have become a close-nit family - thanks so much for your support. I will miss you all.

Lastly thanks to my family for all the support you have given me over the months. Mum, Dad, and Becky for putting up with me when all I could think about was this. Colleen for being mum-away-from-home, and Nanna and Barry for the good wine and good company. 


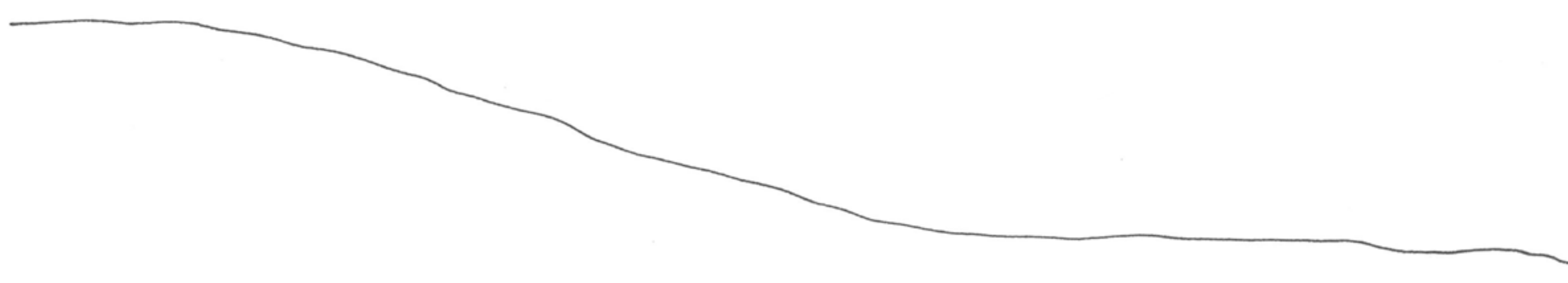


Chapter One:

Introduction 
"The challenge, therefore, is to implement strategies that allow timely reactions to the impacts of climate change before major costs are incurred that could have been avoided with prudent planning. The challenge is not to find the best policy today for the next 100 years, but to select a prudent strategy and to adjust it over time in the light of new information."

Ministry for the Environment: Planning for Climate Change Effects on Coastal Margins (New Zealand Climate Change Programme, 2001)

Thesis question:

\section{Using Wellington Central City as a case study, what is a viable urban design response to rising sea} levels?

Aims:

Coastal recession due to sea level rise is of global importance: a highly likely event with enormous consequences. Sea level rise will affect all major coastal cities in the world, and each one will be forced to respond in a unique way. The aim of this research was to investigate the possible effects of sea level rise on Wellington Central Business District and adjacent waterfronts, and to develop a viable urban design response to a one-metre rise in sea level by the end of the century.

Few realistic response options have so far been provided for sea level rise in harbour cities. The proposed citywide urban design response for Wellington City should generate discourse and improve understanding among city planners and researchers.

Around $50 \%$ of the world's population lives in the critical interface between land and water, and this number is continuing to rise (Douglas, 2001, p. 181). With increasing economic development of coastal and delta areas, more people are exposed to the potential consequences of sea level rise.

Many major cities around the world are investigating the risks of sea level rise, and viable solutions for it. However, Wellington City has only just begun to consider this topic.' 


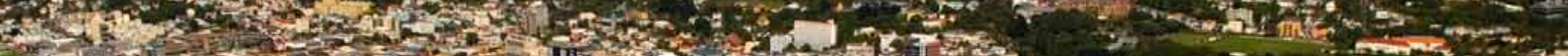

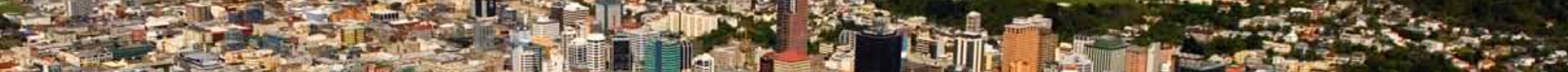
211. Fin

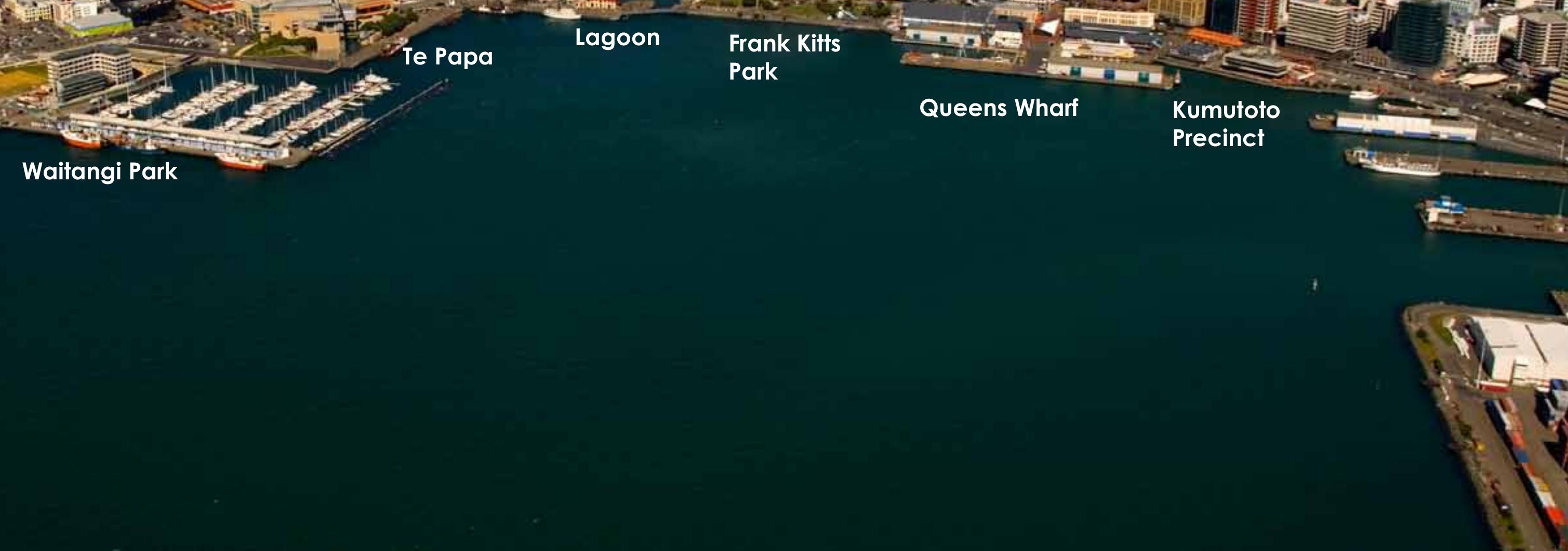

\section{$\cos ^{2}$}

Te Papa

\section{Waitangi Park}

Frank Kitts

Park

\section{Queens Whar}

Precinct 
The exact effects of sea level rise are uncertain. Traditionally tackled from a background of engineering or ecology, sea level rise has rarely been looked at from an urban design perspective. A successful city centre must have ample and enjoyable public space, an essential component of design solutions to sea level rise.

Climate change implies increases in global temperature and a necessity to decrease carbon emissions. This thesis will focus specifically on urban development responses to consequent seal level rise. Sea level rise threats include increases in frequency and severity of coastal floods due to increased rainfall and storm surges.

The underlying theme of this thesis is that we should be preparing now for an uncertain environment in the future. Significant changes in buildings, infrastructure, and lifestyles can offer protection from potential damage, while continuing to support a high standard of living.

In summary, the aim of this thesis is to describe current overseas practice, and, through a comprehensive and detailed design process, to propose a realistic solution to sea level rise for Wellington City that successfully preserves and enhances public space.

Wellington Central City was chosen because of its national importance and because it is typical of many coastal cities around the world. For this study, The site boundaries is defined in figure 1.2, as the area between southern Courtenay Place and Northern Waterloo Quay.

Wellington City is a centre for business, government, education, trade and tourism. It also includes residential and recreation sectors. As much of the site is raised less than two metres above the current median tide level, a large part of New Zealand's funds and assets is vulnerable to sea level rise. Thorough knowledge of Wellington City's history, current state and likely future is essential to ensure any urban design is in context and effective.

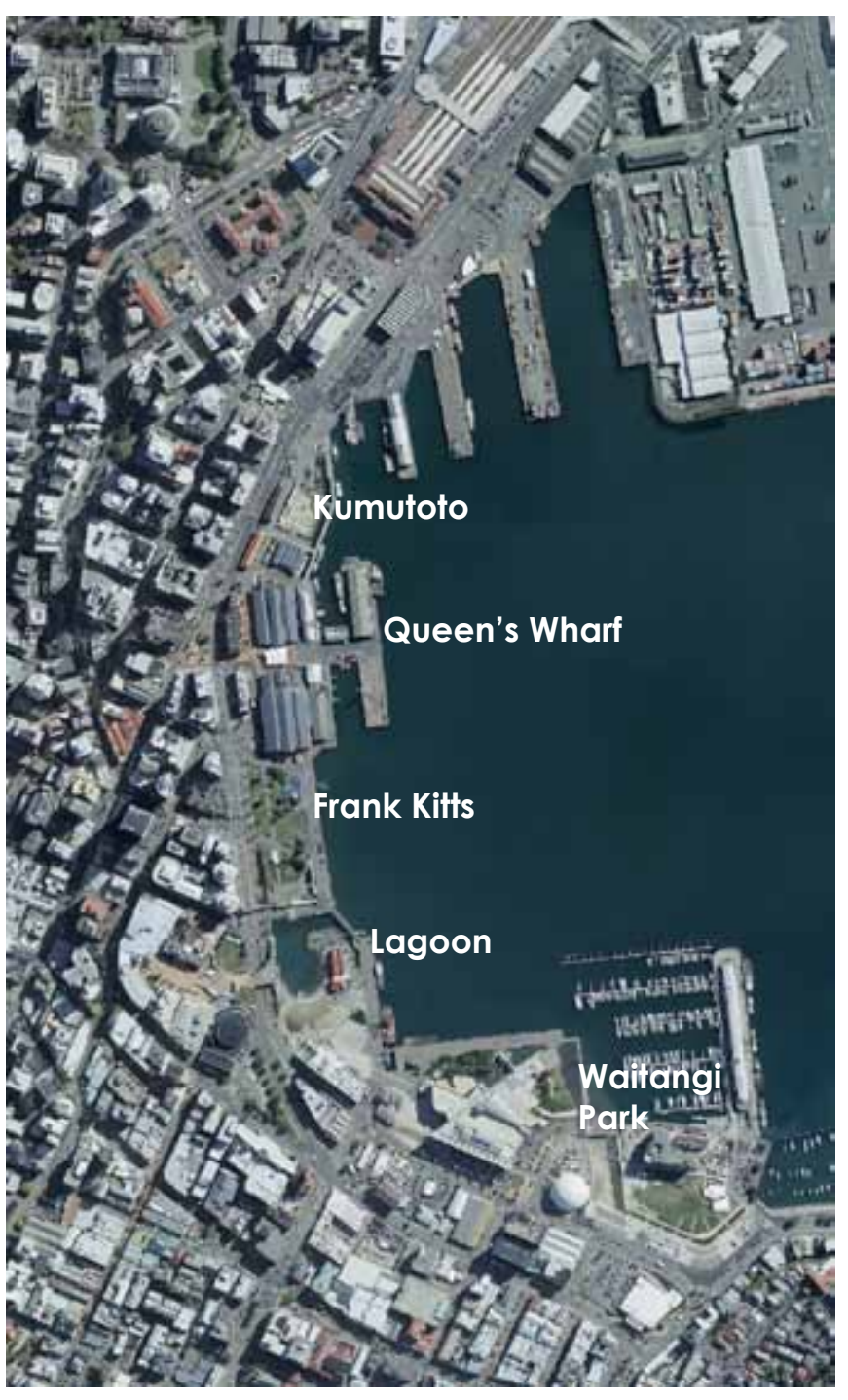

Fig 1.2 Study Site Boundaries: Wellington Central City Image reproduced with permission from Wellington City Council 
This thesis is divided into eight chapters: introduction (chapter 1); literature review (chapters 2, 3, and 4,5); scenario analysis (chapter 6); final design response (chapter 7); discussion and conclusion (chapter 8).

Chapter two explores international literature on sea level rise and describes scenarios for several coastal cities. This global knowledge helps to predict the likely effects of sea level rise on Wellington City and to plan responses to it.

Chapter three defines 'urban design' and determines its key principles and criteria, specifically in regards to coastal cities. Urban design theory from a range of sources is be presented, and considered in regards to development in coastal cities.

Chapter four explores international case studies of structures designed to resist flooding or rising waters. These urban designs respond to sea level rise using three approaches: Protect, Accommodate and Retreat (Arnold, 2003). The relevance of each case study to Wellington City is evaluated.

Chapter five describes Wellington City's history, applicable laws, legislature status and design directive. Current predictions for sea level rise in Wellington are evaluated.

Chapter six offers an analysis of predictions of a range of scenarios for Wellington city. Mapping is used to assess the urban implications of sea level rises of $0.5 \mathrm{~m}, 1.0 \mathrm{~m}$ and $2.0 \mathrm{~m}$ with detailed analysis of a $1.0 \mathrm{~m}$ rise.

Chapter seven describes a viable urban design solution for a 1.0 metre rise in sea level in Wellington City. Design and process is illustrated using diagrams and visualisation images. Evaluation outlines the design's deficiencies and areas requiring further investigation.

Chapter eight, as a conclusion, discusses the research process and effectiveness of the final design. 


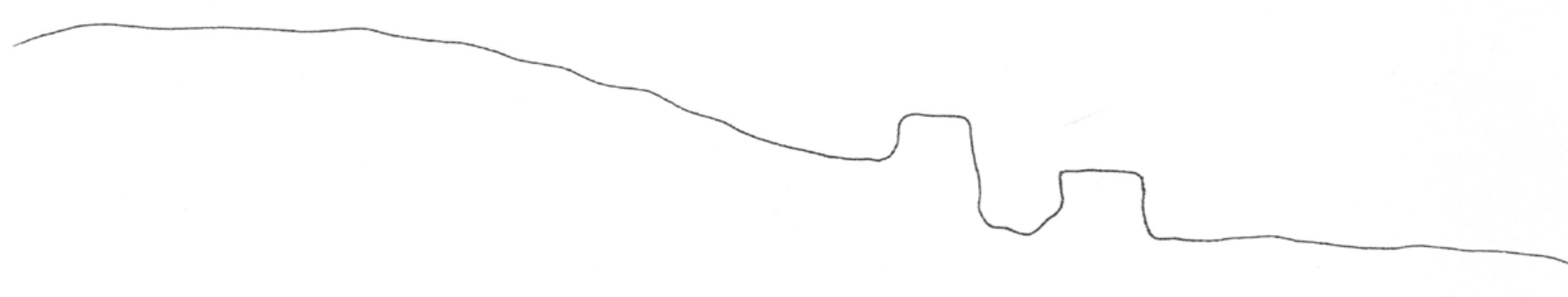


Predictions for sea level rise and their consequences have promoted considerable research in various cities around the world.

About 100 million people worldwide live less than one metre above mean sea level (Downing, 2007, p. 64); many are in large and expanding cities on low-lying land. A rise of 1 metre is at the upper end of a range of estimates for the next hundred years, and will have drastic consequences.

Over the last half-century, sea level has risen an average of a couple of millimetres a year. The rate appears to be accelerating because of increase in global temperature and melting of land-based glaciers and ice sheets (Intergovernmental Panel on Climate Change, 2007, p. 30). Predictions are vague. Accurate and reliable information about current and future climate and socioeconomic trends are needed to design for the future.

Even without confident predictions, design solutions have been proposed for New York, London, San Francisco, Amsterdam and Venice, and ideas are appearing for coastal cities around New Zealand. Little literature has been produced concerning sea level rise urban design implications, or the urban design implications of possible responses.

\subsection{SEA LEVEL RISE PREDICTIONS}

Scientists are undecided on exactly how much, and how quickly the seas will rise over the coming century. Nevertheless, all are in agreement that the seas are rising; and because of the huge thermal mass of the oceans, they will continue to do so even if greenhouse gas emissions are radically reduced today (Downing, 2007, p. 62).

The Intergovernmental Panel on Climate Change (IPCC) is a scientific intergovernmental body established by the United Nations, and is responsible for global predictions of climate change (RG Bell, 2001, p. 19). According to the IPCC, in the $20^{\text {th }}$ Century, the major contributors to sea level rise were, in descending order of importance:

- Thermal expansion of the oceans

- Mountain glacier melting

- Melting of the Greenland ice sheet

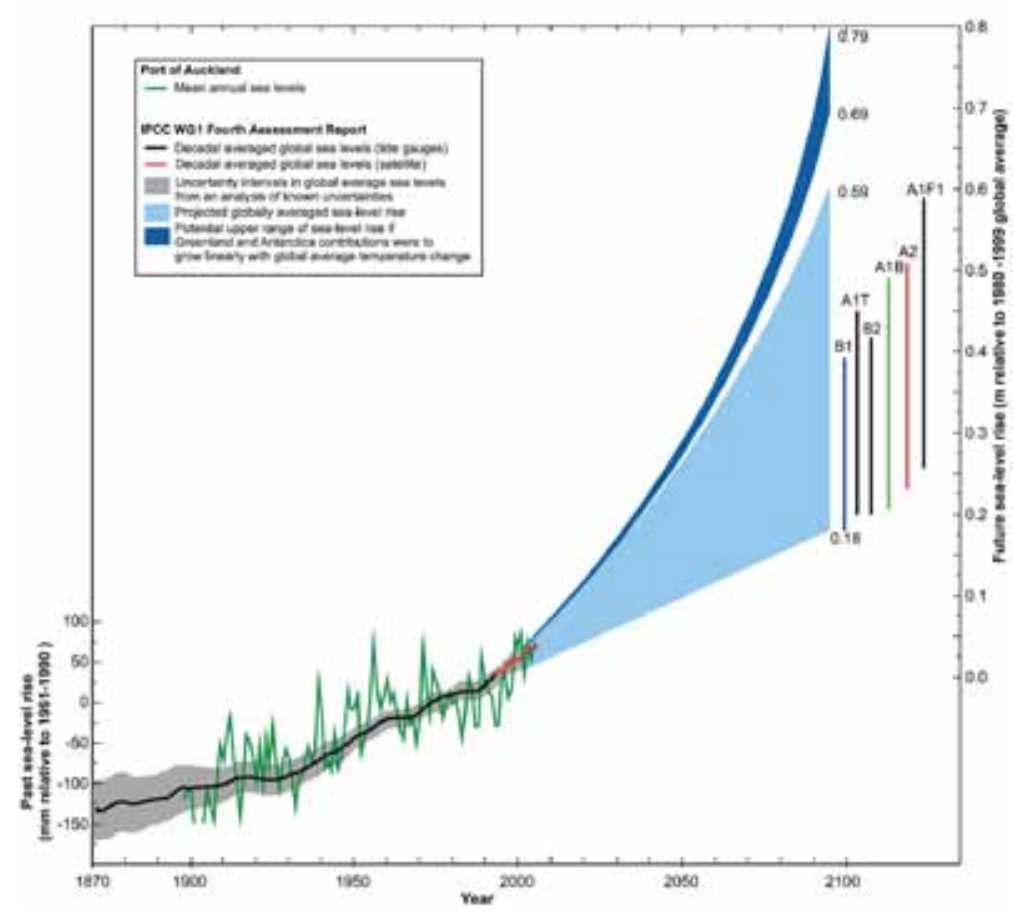

Fig 2.1 Predictions of global mean sea level rise to the mid 2090s. Light blue = range in projected mean sea level out to the 2090 s. Dark blue line = potential additional contribution from Greenland and Antarctica Ice Sheets if contributions to sea-level rise grow linearly with global average temperature change. Vertical coloured lines = range in projections from various GCMs for six emission scenarios. Sourced from the Ministry for the Environment's Coastal Hazards and Climate Change Manual 
The IPCC predicts that in coastal regions, sea level rise will be the most fundamental challenge of global warming that human settlements face (Intergovernmental Panel on Climate Change, 2001). Its latest report, The Fourth Assessment Report of the Intergovernmental Panel on Climate Change (2007) states that by the year 2099, sea levels will rise between 0.18 and $\mathbf{0 . 5 9 m}$ (p.8) [Seep table 2.2 for projections]. However, it notes:

Because understanding of some important effects driving sea level rise is too limited, this report does not assess the likelihood, nor provide a best estimate or an upper bound for sea level rise.

(Intergovernmental Panel on Climate Change, 2007, p. 45)

There is growing scientific agreement that the impacts of climate change predicted in the IPCC report of 2007 were seriously underestimated. In February 2009, Dr. Chris Field, co-chair of the IPCC stated:

We now have date showing that, from 2000 to 2007, greenhouse gases increased far more rapidly than we expected, primarily because developing countries, like China and India, saw a huge upsurge in electricity power generation, almost all of it based on coal.

(Sample, 2009)

Most predictions of the future of sea level rise are higher than the IPCC's initial estimate (Pilkey, 2009 , p. 79). Other studies have been published which conclude a maximum of $1.25 \mathrm{~m}$, and $0.89 \mathrm{~m}$ rises by the same date (Ramsay, 2008, p. 19). '

The other main contributor to variations in sea level is storm surge: predicted larger storm surges can add several metres to local sea level for periods of hours or days. These come with large and powerful waves. Cities will face more frequent and more severe hurricanes and storms. (Ministry for the Environment, 2001, p. 3).

A perfect forecast of sea level rise and associated effects is not critical for this investigation. The final design will consider various levels of sea level rise, and allow expansion if seas rise higher than predicted.

\begin{tabular}{|c|c|}
\hline \multirow{2}{*}{ Case } & $\begin{array}{c}\text { Sea level rise } \\
\text { (m) at 2090-2099 relative to 1980-1999) } \\
\text { Model-base range }\end{array}$ \\
\hline B1 scenario & $\begin{array}{c}\text { Excluding future rapid dynamical changes in ice flow } \\
0.18-0.38\end{array}$ \\
\hline A1T scenario & $0.20-0.45$ \\
\hline B2 scenario & $0.20-0.43$ \\
\hline A1B scenario & $0.21-0.48$ \\
\hline A2 scenario & $0.23-0.51$ \\
\hline A1F1 scenario & $0.26-0.59$ \\
\hline
\end{tabular}

Table 2.1 Projected global average surface warming and sea level rise at the end of the 21 st century

This range is based on projections from 17 different global climate models for six different future emission scenarios. Projections exclude rapid dynamical changes in ice flow. Table sourced from the IPCC 4 th Assessment Report.

Two estimates of higher sea level rises than suggested by the IPCC Fourth Assessment Report are provided by the Rahmstorf study and the Horton study. The Rahmstorf concluded that a sea-leve rise of between $0.55 \mathrm{~m}$ and $1.25 \mathrm{~m}$ is possible by $210010.50 \mathrm{~m}$ to $1.40 \mathrm{~m}$ with statistical orror). The Horton study predicted a rise of $1.40 \mathrm{~m}$ with statistical enror). The Horton study predicted a rise of between $0.54 \mathrm{~m}$ and $0.89 \mathrm{~m}$ by $2100(0.47 \mathrm{~m}$ to $1.0 \mathrm{~m}$ with statistical estimates sea-level rise indirectly from changes in global-average near-surface temperature. 
How global sea level rise will manifest itself on a regional scale is uncertain (The International Bank for Reconstruction and Development, 2003, p. 106). Effects on coastal cities may include:

- $\quad$ Erosion of beaches and breaches of coastal protection structures (Ministry for the Environment, 2001, p. 3). Destruction of reefs and wetlands (Burton, 2009, p. 421).

- Landward incursion of estuaries, beaches, wetlands and marshes.

- Saltwater contamination of surface water, river water and groundwater in lowlands (McFadden, 2007) affecting agriculture and natural ecosystems, water quality, sanitation, and stormwater drainage.

- Loss of habitat and biodiversity in marshes, mangroves and coral reefs due to increased rainfall (RG Bell, 2001, p. 12). Loss of aquaculture, fishery and marine infrastructure (Pilkey, 2009, p. 132).

- Inundation of private and public, commercial and residential property. Public spaces and roading may be destroyed by coastal storms, sea surges and flooding. Cherished buildings, monuments, and archaeological sites are threatened.

- Damage to essential infrastructure such as sewage systems, flood control, coastal defences, transportation, infrastructure and wastewater plants (Bicknell, 2009, p. 263). Pollution of domestic water supplies (Pilkey, 2009, p. 137).

- Threats to electricity supply: gradual sea level rise does not pose a threat to electricity generation or supply, but difficulties are likely in response to extreme events (Bicknell, 2009, p. 264).

There is little accepted theory on the urban implications of sea level rise. Most predictions have focussed on physical effects, using mathematical calculations. The authors of the book Adapting Cities to Climate Change pose the question: Do climate change and disaster specialists understand what drives and shapes urban change? They answer: 
With a few honourable exceptions, the literature suggests that they have a simplistic, often stereotyped 'urban population explosion' or 'rural push/urban pull' view of urban change. This often fails to consider why urbanisation Is taking place, what drives people to concentrate in specific urban locations, and what particular processes make the population of each urban centre vulnerable to environmental hazards.

(Bicknell, 2009, p. 16)

Worldwide, there has been considerable research into the options for cities should sea levels rise. For example, well-developed and active precedents exist in Britain, The Netherlands and Venice (Italy), where citizens have been battling the sea for generations. A mere half-metre rise in sea level could potentially cause substantial harm in many large coastal cities. Previous seawater incursions have informed the design of coastline defence systems.

New York recently held a six-month public competition, Rising Currents, which was presented as an exhibition between March and October 2010 at the MoMa galleries in New York (MoMa, 2010). Five teams of professional architects, engineers, urban designers and artists suggested a diverse range of response options. They aimed to persuade the US government to think more creatively about sea level rise, and to encourage greater public awareness (Ouroussoff, 2009).

San Francisco also held an international competition, funded by the San Francisco Bay Conservation and Development Commission (BCDC) to offer solutions to a rise in the sea level of San Fransisco Bay of 55 inches above today's high tide. Entries were displayed to the public in an exhibition opened in July 2009 (Rising Tides Competition, 2009). Addressing the issue that the problem has 'many sides to it' (King, 2009), a number of solutions were chosen as winners: a mechanical levee powered by tidal turbines of geothermal energy; a scheme aiming to transform parts of the city to marshes; and another that focussed on green infrastructure along existing roads and streets.

Public design competitions are important for gaining publicity around the topic of sea level rise, which in turn helps to educate citizens on the possible effects to their personal life, and their city. Competitions such as these generate public and political discourse around the subject. An increasing number of people involved in, or as a result of, these projects are taking the possibility of the higher range of estimates for sea level rise very seriously.

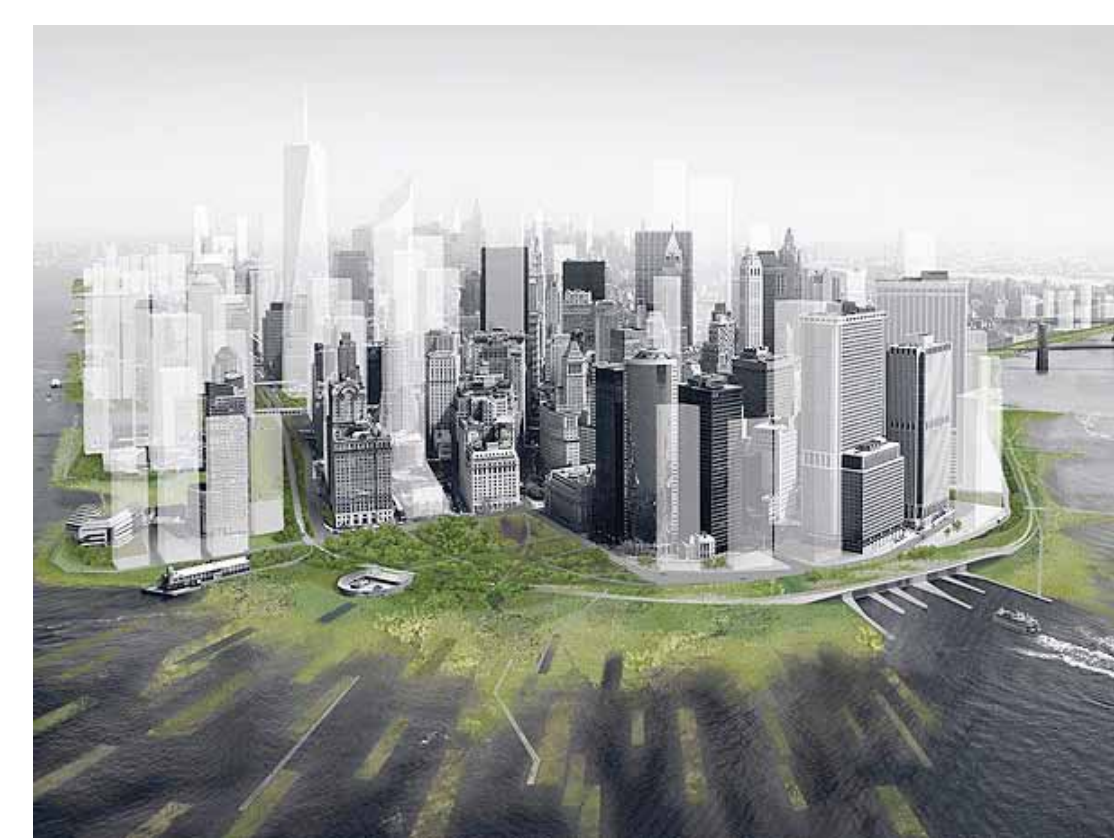

Fig 2.3 MoMA Exhibition: Rising Currents

Zone 0 visualisation: Architecture Research Office and Dlandstudio's New Urban Ground transforms Lower Manhattan (New York) with an infrastructural ecology 
Coastal cities will need to quickly adapt to sea level rise, fundamentally changing the way buildings and urban spaces are designed. Preparing a city for sea level rise should be considered a matter of urgency by those involved in the design of coastal cities. Coastal management and planning should be carried out assuming that rise will occur, and will continue to accelerate. Potential threats of sea level rise, and possible design alternatives must be discussed in the public forum.

There is such a broad range of predictions for sea level rises that at present, no specific figure can be relied upon. Urban design strategies need to consider a variety of predictive modelling and engineering responses. Design alternatives should be offered for a range of scenarios in each affected city. This thesis will attempt to provide one possible answer to a possible scenario. 


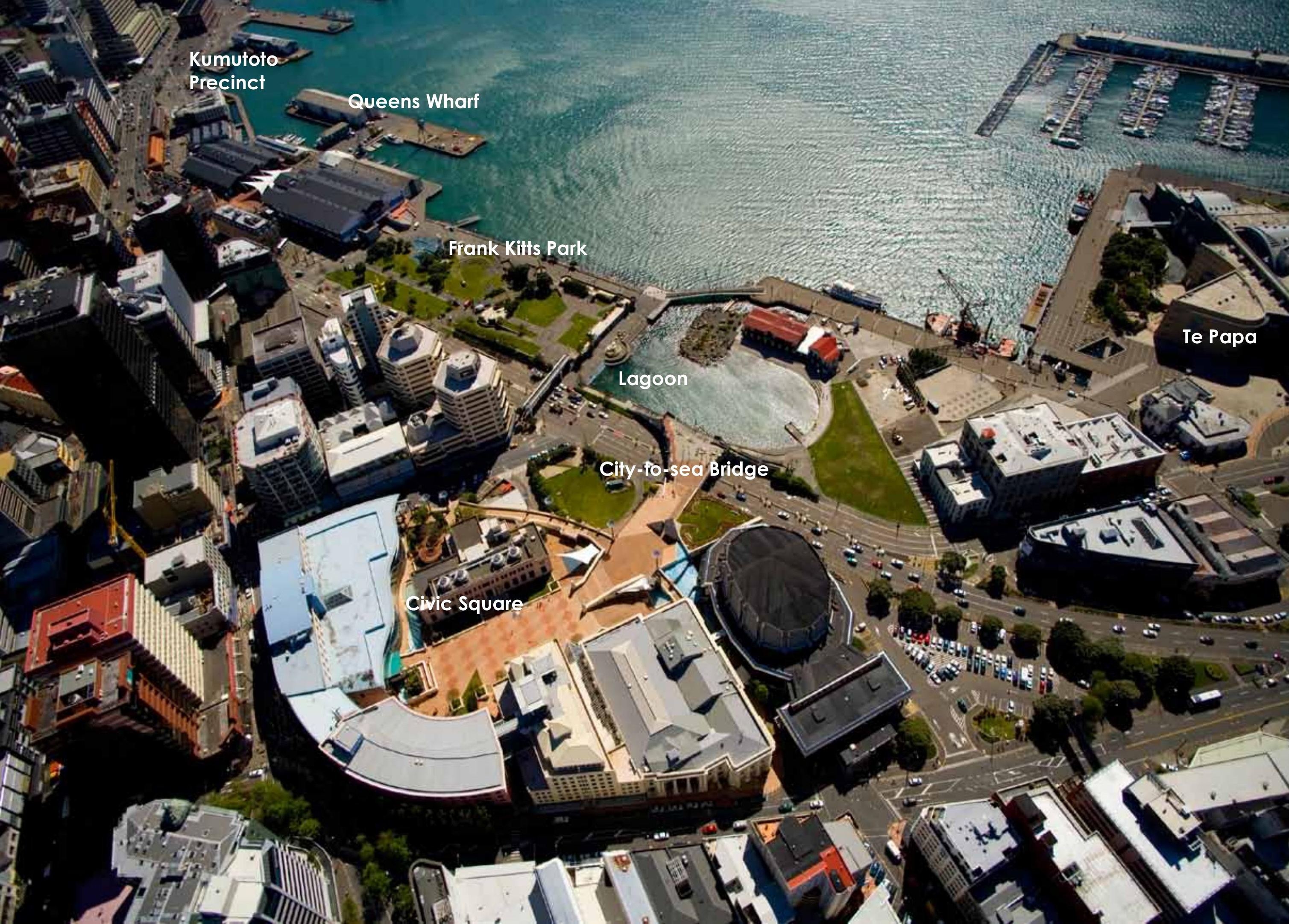




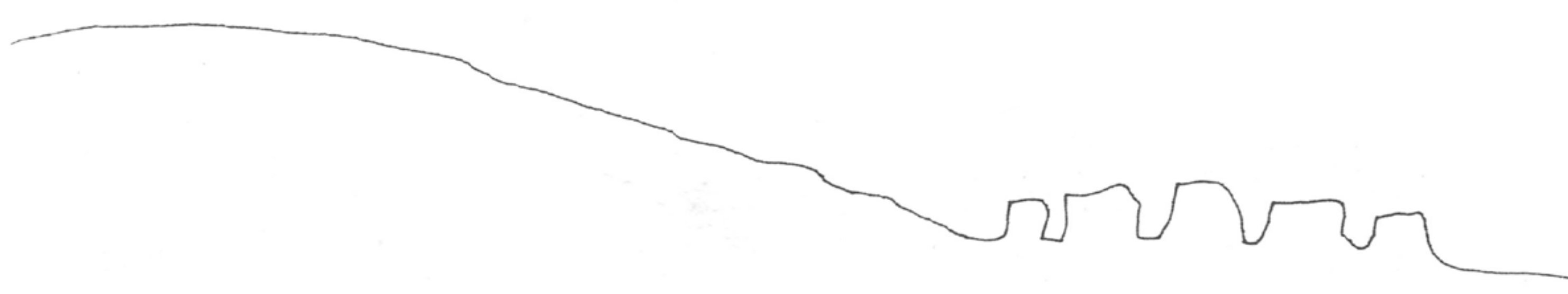


Chapter Three:

Urban Design Theory 
A successful urban design response to sea level rise for Wellington City's waterfront must adhere to standard urban design principles especially for urban space. Effective design and implementation requires community involvement.

Urban design has its focus on the built environment that exists within an urban setting. It centres on the human experience, identity, and spatial awareness. The broad goal of urban design is to improve the built environment, and to provide opportunities for all citizens and visitors to enjoy a city. Urban designers strive to create, or, influence, good quality spaces across private properties and public realm (Carmona, 2007, p. 34).

Although urban design is an accepted field of planning, it lacks cohesive theoretical foundations. Guidebooks and manuals rely on rule of thumb or analytical techniques, and reproduce published proverbs by founding theorists. Despite the existence of a broad range of publications, there is little urban design theory specific to waterfronts, and almost none that relates to sea level rise. This absence parallels a similar gap in practice and public policy.

Urban design theory regarding responses to sea level rise is quite possibly non-existent. No established methods of creating successful urban spaces have been found by searching for publications on sea level rise. Most of the few responses to sea level rise rely on well-established engineering principles, or exist only as paper architecture: inventions not yet constructed. Analyses of these mostly neglect the urban implication of the designs.

As arguably the most important element within a city, public space is a term used predominantly by urban designers. Also referred to as the public domain, or public realm, public space is defined by Cowan, in The Dictionary of Urbanism (2005) as:

The parts of a village, town or city [...] that are available, without charge, for everyone to see, use and enjoy, including streets, squares and parks; all land to which everyone has ready, free and legal access 24 hours a day. 
Although the definition of public space is clear, the urban design discipline has never wholeheartedly agreed upon a concise definition of good public space. In the seminal text for designers, Responsive Environments (1985), lan Bentley and his associates define good public space as including many of, (but not limited to) the following virtues: permeability, variety, legibility, robustness, visual appropriateness, richness, and personalisation (Bentley, 1985, p. 11). Other theorists have provided slightly different definitions; however, most agree on the principles.

Henry Shaftoe, in his book Convivial Urban Spaces (2008), stresses a need for different types of observation and communication in public spaces. A good public space must accommodate people who are there to 'watch the world go by', people hoping for 'casual interaction' and people interacting with close friends (p.53).

He also stresses the need for legibility, a sense of safety (p.55), and an element of mystery:

We like to be intrigued by the possibility that there is more to a space than initially meets the eye and that if we move through it there may be further intriguing discoveries.

(Shaftoe, 2008, p. 55)

Shaftoe believes that people feel comforted by experiencing natural elements in the landscape. Although some of this is experienced visually, a major part is experienced through hearing or touch. Examples of 'non-visual aesthetic experiences' are the feeling of surfaces underfoot, the experience of climbing or descending within a space, or 'the air or wind against our skin' (Shaftoe, 2008, p. 59).

Perhaps the most concise and directive published set of principles, The Urban Design Compendium,' published by the British Commission for Architecture and the Built Environment (CABE), presents a number of generally accepted models and guidelines for public space design. The Compendium stresses that open spaces be designed with clear definition and enclosure. Each space must be given a clear function, character and shape so that there is no ambiguity or unclear boundaries between public and private realms (English Partnerships and Housing Corporation, 2007, p. 86). 
The Urban Design Compendium (2007) places importance on walkability. Walkability is defined as 'The ease with which it is possible to walk around an area, from one point to another' (Cowan, 2005, p. 313), is assessed by footway quality, proximity to transport facilities, signage and ground level activity. The Compendium defines 5 principles of walkability: Connections, Convenience, Convivial, Comfortable, and Conspicuousness (English Partnerships and Housing Corporation, 2007, p. 71). The Compendium suggests that more streets should be designed for low speeds so that pedestrians, cyclists and vehicles can mix safely. It emphasises that walkers should be given primacy in the urban environment being the apex of the transport hierarchy. CABE propose:

It is no accident that those British cities which are regarded as highly successful in urban design terms (e.g. Oxford, Cambridge, Bath and York) were laid out when walking was a primary means of locomotion and have retained their basic plan ever since.

(CABE, 2001)

\begin{tabular}{|c|c|c|c|c|}
\hline $\begin{array}{l}\text { UDC1 } \\
\text { Key aspects of } \\
\text { urban design }\end{array}$ & $\begin{array}{l}\text { By Design } \\
\text { Principles of } \\
\text { urban design }\end{array}$ & $\begin{array}{l}\text { Princes Foundation } \\
\text { Design and } \\
\text { theory principles }\end{array}$ & $\begin{array}{l}\text { Responsive } \\
\text { Environments }\end{array}$ & $\begin{array}{l}\text { PPS1 } \\
\text { Principles of good design }\end{array}$ \\
\hline \multirow[t]{2}{*}{ Places for people } & $\begin{array}{l}\text { Quality of the public } \\
\text { realm }\end{array}$ & \multirow[t]{2}{*}{ Make Places } & \multirow[t]{2}{*}{ Robustness } & \multirow{2}{*}{$\begin{array}{l}\text { create an environment where } \\
\text { everyone can access and } \\
\text { benefit from the full range } \\
\text { of opportunities available to } \\
\text { members of society }\end{array}$} \\
\hline & $\begin{array}{l}\text { Continuity and } \\
\text { Enclosure }\end{array}$ & & & \\
\hline \multirow[t]{2}{*}{ Enrich the existing } & \multirow[t]{2}{*}{ Character } & \multirow[t]{2}{*}{ Build beautifully } & Visual appropriateness & \multirow{2}{*}{$\begin{array}{l}\text { be integrated into the existing } \\
\text { urban form and the natural and } \\
\text { built environments }\end{array}$} \\
\hline & & & Richness & \\
\hline \multirow[t]{2}{*}{ Make connections } & Ease of Movement & \multirow[t]{2}{*}{$\begin{array}{l}\text { Allow movement } \\
\text { logically and legibly }\end{array}$} & Permeability & $\begin{array}{l}\text { be integrated into the existing } \\
\text { urban form and the natural and } \\
\text { built environments }\end{array}$ \\
\hline & Legibility & & Legibility & $\begin{array}{l}\text { address the connections } \\
\text { between people and places by } \\
\text { considering the needs of people } \\
\text { to access jobs and key services }\end{array}$ \\
\hline $\begin{array}{l}\text { Work with the } \\
\text { landscape }\end{array}$ & & $\begin{array}{l}\text { Design using natural } \\
\text { harmonics }\end{array}$ & & $\begin{array}{l}\text { consider the direct and indirect } \\
\text { impacts on the natural } \\
\text { environment. }\end{array}$ \\
\hline Mix uses and form & Diversity & $\begin{array}{l}\text { Engender social } \\
\text { interaction }\end{array}$ & Variety & $\begin{array}{l}\text { address the connections } \\
\text { between people and places by } \\
\text { considering the needs of people } \\
\text { to access jobs and key services }\end{array}$ \\
\hline $\begin{array}{l}\text { Manage the } \\
\text { investment }\end{array}$ & & Sustain land value & & \\
\hline Design for change & Adaptability & & Personalisation & $\begin{array}{l}\text { create an environment where } \\
\text { everyone can access and } \\
\text { benefit from the full range } \\
\text { of opportunities available to } \\
\text { members of society }\end{array}$ \\
\hline
\end{tabular}


There is very little urban design theory specific to waterfronts. Most refer to all-encompassing masterplans, and are less particular about the public realm. However, most urban design principles can be applied to waterfront design.

Building on established principles, August Heckscher in the book Open Spaces (Heckscher, 1977), advises that the following standards be observed if open space is to be fully realised in city waterfront developments:

- Maintenance of visual connections between the central city and the water

- $\quad$ Access by pedestrians to waterside promenades and parks

- $\quad$ Limited-use drives and landscaped parkways providing views of the water

- Abatement of water pollution to allow use of the waters for recreational activities

- Preservation of historic areas with their long-standing orientation toward the water

The importance of local context in city waterfront design has mostly been ignored by urban theorists. ${ }^{2}$ Tim Edensor, in his essay Caudan: Domesticating the Global Waterfront (Edensor, 2006), suggests that since emerging out of North America in the 1960s, the concept of waterfront development has become a banal element in strategies to regenerate and reinvent the image of post-industrial port cities of the developed world (Edensor, 2006, p. 205). He suggests that cities in Europe, Asia, Africa and Australia that have 'revitalised' their waterfronts, have instead assembled versions of a 'worn-out copy of numerous other Western waterfronts'. Edensor uses the Port Lovis waterfront, in the capital city of the island of Mauritius in Africa (see fig 3,2), as a victorious antithesis of this. He attributes Port Luis's success to 'complexity', a 'varied mix of functions, public and private space, people and practices and architectural texture' and an offer of 'a largely local array of goods and services and its venue for particular forms of social practices which have emerged out of a distinct, local context' (Edensor, 2006, p. 215).

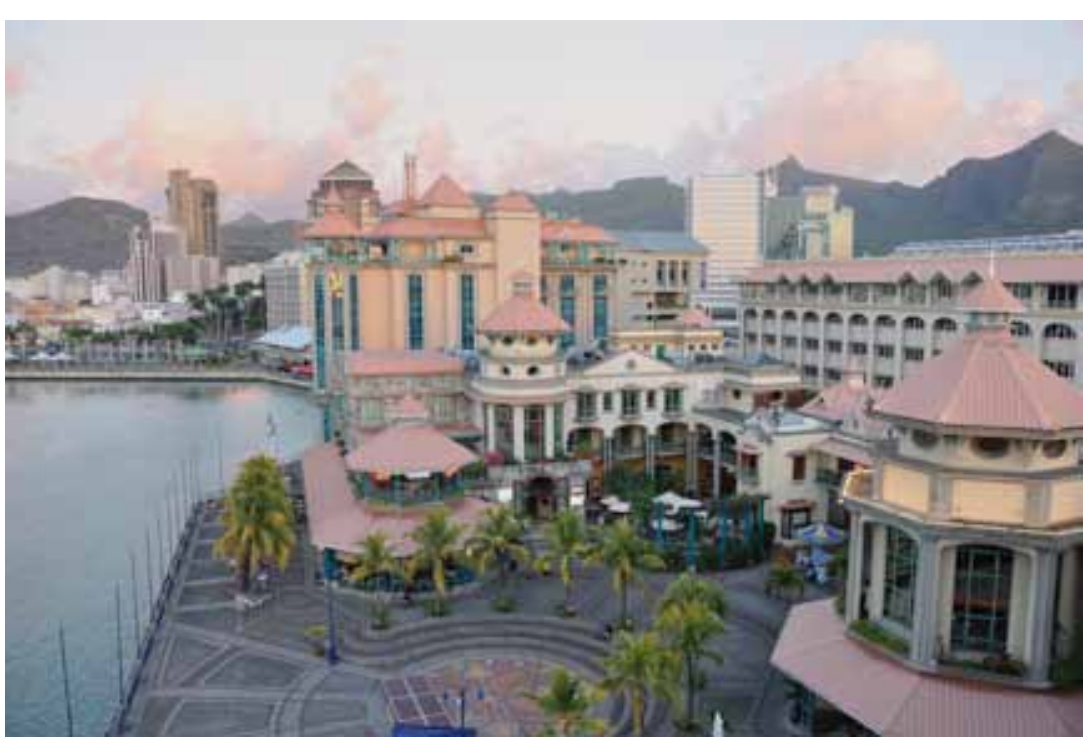

Fig 3.1 Port Luis Waterfront, Mauritius Island 
Private entrepreneurs that create large-scale property developments often play a significant role in development of urban landscape. Concurrently public institutions must often rely on private sector investment in developing the public realm. There are various ways to regulate private development; outcomes depend on open processes and communication.

Cities often grow when the economy is strong, with city government merely regulating growth (Willis, 2002, p. 18). Developers' attitudes towards quality design vary, and are governed by opportunities for profit. They are not necessarily opposed to governmental controls as long as the controls do not inhibit their work arbitrarily (Lang, 2005, p. 19).

Controls can exist though zoning rules, as described in the Wellington District Plan. Zoning is traditionally used to establish regulations such as height and size of buildings, function, setbacks and material usage. Guidelines within zoning rules are used to judge whether or not certain developments should proceed.

A city may grow intensively following a single all-of-a-piece urban precinct masterplan. Masterplans can be very costly, often decided upon by one ruling body, and are more likely to engender public disapproval. An exemplar of 'all-of-a-piece' urban precinct design (Lang, 2005, p. 240) is the 1979 plan for Battery Park City (New York), which has been criticised for its ineffective, allencompassing approach (see figures $3.3 \mathrm{a} \& \mathrm{~b}$ ). Although Battery Park City was a financial success, political infighting and bad public opinion of the initial masterplan design has contributed to the reason the term 'masterplan' is heard infrequently today (Gastil, 2002, p. 46).

Another way to regulate good urban design is through a 'pact.' An example of this is The Thames Gateways Design Pact, to be signed by authorities involved in development along the Thames River in Kent, Essex and London. Resulting from a study by CABE, which mapped the landscape urban character of the area, the pact set standards for authorities to ensure that new development is of high quality and in line with the character of the area. A guide, issued to developers involved in the pact, refers to urban design manuals (see fig 3.3). Significant schemes must be submitted to design review before construction (CABE, 2008, pp. 4-13). Housing audits of the quality of construction must be completed; the aim being that by 2015, 100\% of all new construction will be rated as 'good', or 'very good' (English Partnerships and Housing Corporation, 2007, p. 43). The pact is a ministerial guidance, and is required for all planning applications (CABE, 2008, p. 15). This pact is useful as a precedent for Wellington City, as it allows development to be directed by multiple

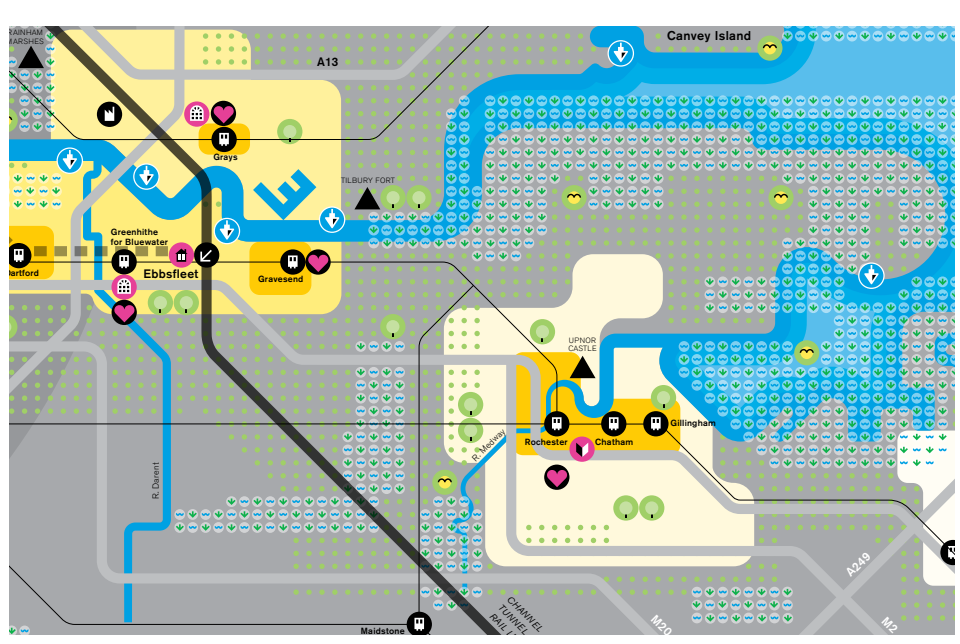

City/urban Urban/country

Industry/country Country/urban

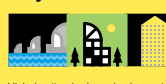

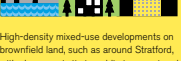

Pipip

$\Delta \pm$ D
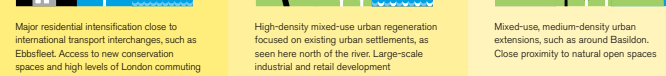

Fig 3.2 Thames Gateway Design Pact ip

The images above are souced from a 'map' which illustrates how the character of the Thames Gateway is set to how the character of the Thames Gateway is set to
develop. The yellow keys describe the characteristics of different places along the Thames. The above image is a section of the map, showing growth around existing settlements and the different characteristics of each. 
territorial authorities and public/private partnerships. The 'pact' also leads to a desirable long-term outcome of making the urban fabric resilient to a range of flooding possibilities.

Collaborative decision making was essential to the Vancouver Waterfront. Its development was regulated by teams of developers and city staff, and entailed much public consultation ${ }^{3}$. Masterplans were converted into official development plans and guidelines (Sandercock, 2006). Developers worked with planners to improve the urban quality of neighbourhoods: land was put aside for public entities such as schools, libraries, and day-care centres. Now hailed as 'The Vancouver Achievement' (Punter, 2003), this pioneering method of planning produced excellent architecture, urban design and 'outstanding public realm' (Sandercock, 2006, p. 55).

A number of urban design principles used in creating effective and lively public spaces have been described. It is important to consider urban design imperatives when designing in the public realm. The imperatives to be addressed specifically by the final design are:

- $\quad$ Access (both physical and visual)

- Heritage

- Process of implementation.

These principles can be applied to sea level rise responses to ensure the design contributes positively to a city.

The greater success of some waterfront developments compared to others is often attributed to the process by which design and implementation has been carried out. It is important to adopt a clear strategy and to consult with a wide range of stake-holders throughout the design, construction and evaluation phases of a project.

These principles should be followed when designing for sea level rise to improve a city's urban design fabric. They are used to assess the flood-resilient design precedents described in the next chapter.
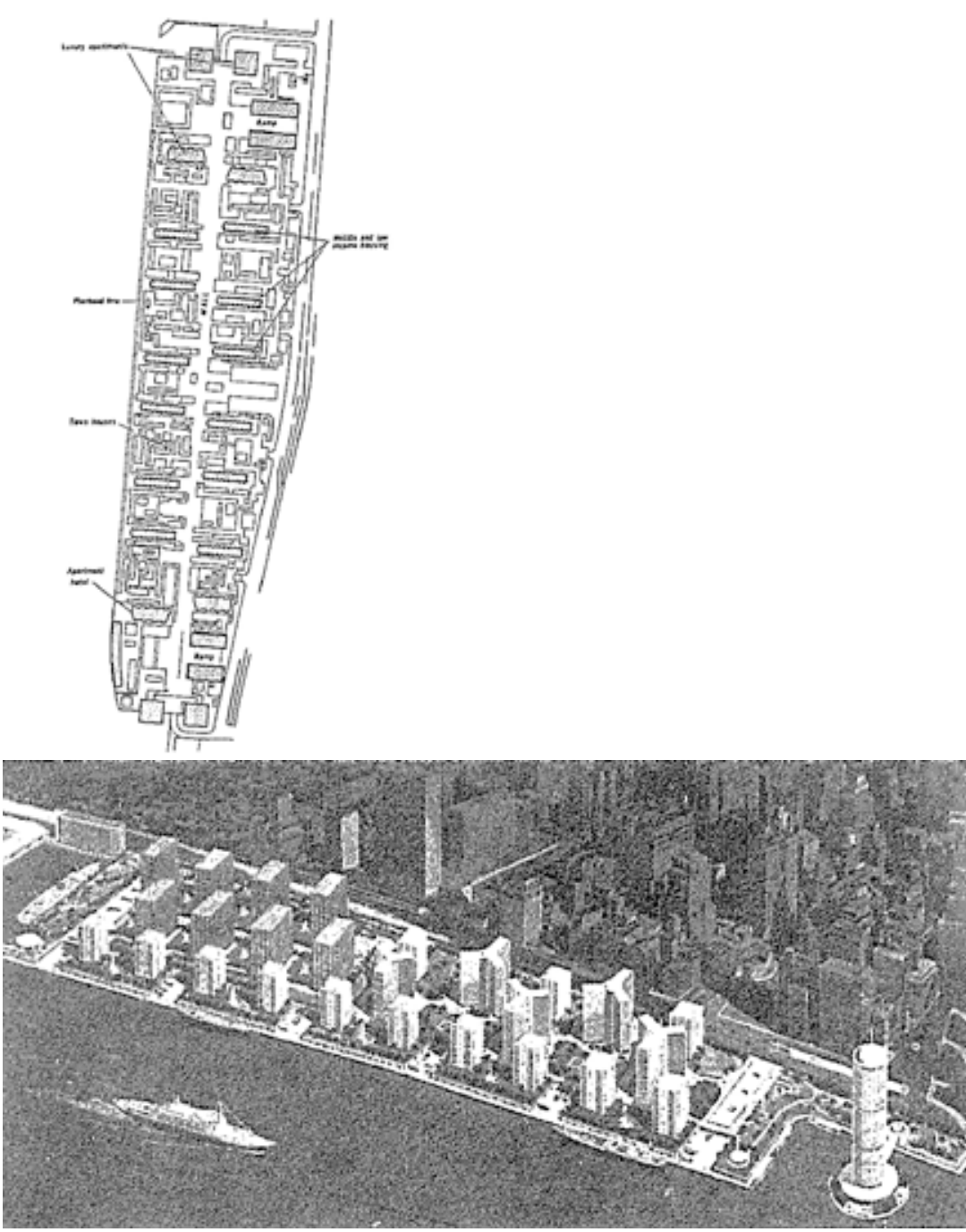

Fig 3.3 a\&b Battery Park City Masterplan

This plan (By Harrison and Abromowitz as Governer Rockfeller's proposal) was presented in 1962. It poorly recieved by the press, the public and by government officials. A series of alternative proposals followed.

Over 200 meetings were held during the negotiation stage during 1988-1993. (Sandercock, 2006, p. 55) 


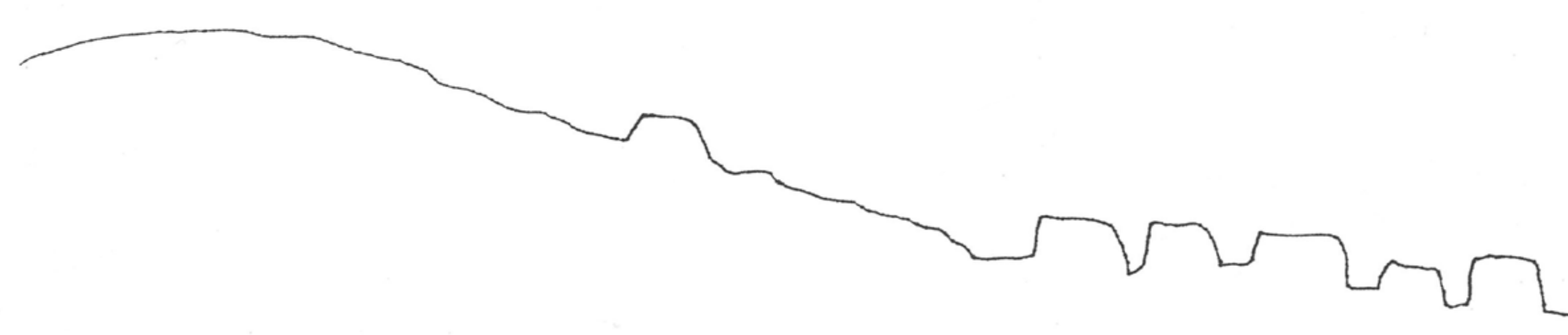


To effectively combat sea level rise, researchers, policymakers, residents and other stakeholders need to work together. There are several options for response methods available to designers, exemplified by recently-constructed flood defence strategies from around the world.

The World Bank's Department for Reconstruction and Development P.109 (Alcira Kreimer, 2003) concluded that coastal cities have the following three possible responses to sea level rise:

\section{Protect:}

To reduce the risk of the event by decreasing the probability of its occurrence

\section{Accomodate:}

To increase society's ability to cope with the effects of the event

\section{Retreat:}

To reduce the risk of the event by limiting its potential effects

International case studies illustrate the urban design aspects of each response method and its relevance to Wellington's CBD. 


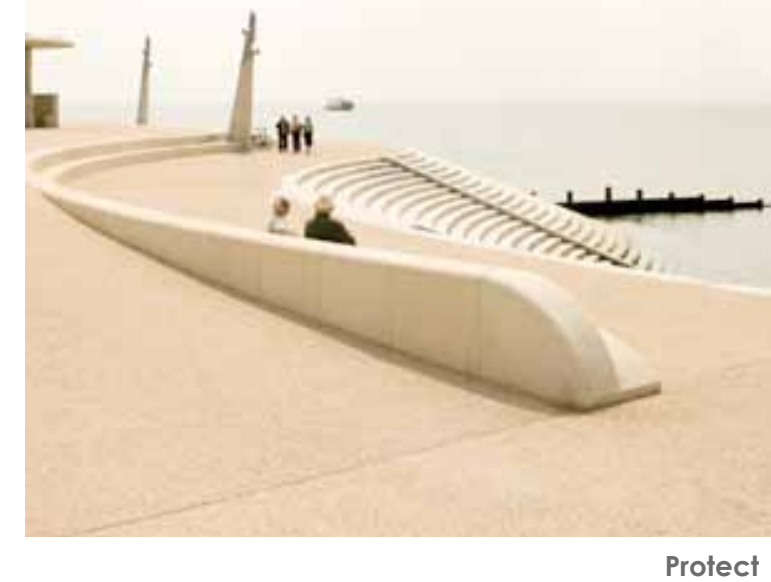

Cleveleys Seawall, Lancashire

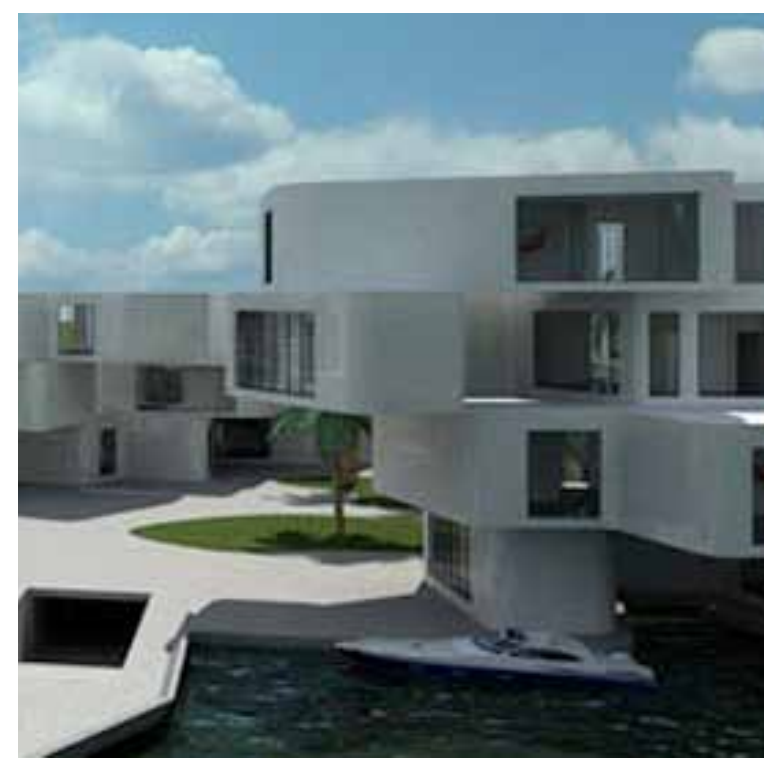

Accommodate Citadel, The Netherlands

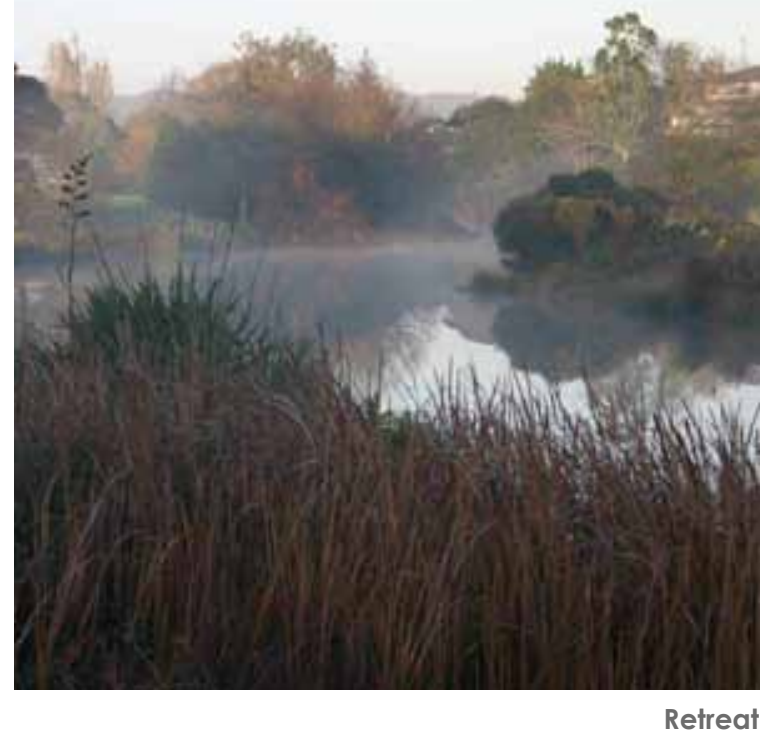

Waitakere River, Auckland 
The goal of protection is to allow existing land use activities to continue despite rising water levels. Protection of the coastlines has been the preferred approach to the threat of rising water for centuries. The conventional form of protection is often referred to as 'hard' engineering; fortifying the coastal infrastructure with mechanisms such as seawalls, gabions and floodgates. This has often been at the expense of natural ecosystems, and, at times, quality of urban spaces (Guy Nordenson, 2008).

During the last few years there has been growing recognition of the benefits of 'soft' protection measures, such as beach nourishment, dune stablisation and wetland creation (Warren, 2007). These measures can be implemented incrementally as sea level rises, and are therefore more flexible than traditional 'hard' responses.

Two case studies describe established methods of protecting a city from water: mechanical flood barriers and a sea wall. Each has been designed in a non-traditional manner, and both are considered successful in terms of engineering and urban design.

\subsubsection{THAMES ESTUARY PROJECT, LONDON}

London is preparing itself for sea level rise. The River Thames, which could flood the city during heavy rainfall and tidal surges, is the greatest threat to the city (Nordenson G. a., 2010, p. 51). Built in 1983, the Thames River Barrier currently protects 1.25 million Londoners and 4,000 properties from periodic flooding by surges up to $4.5 \mathrm{~m}$ high. The gates, which usually lie flat along the riverbed, are only raised when a high tide or flood is forecast (London Boroughs of Greenwich and Bexley, 2005).

The British Government has recognised that according to current sea level rise predictions, the gates are not expected to be effective past the year 2030, by which time the gates are expected to have been raised around 30 times a year (Balmer, 2009). Modification of the gates to accommodate a predicted possible 2-metre increase in sea level rise is being investigated (The Environment Agency, 2010).

Acknowledging that the gates must not be the city's only form of defence, the government project TE2 100 Environmental Strategy: Thames Estuary (2009) aims to create a long-term flood

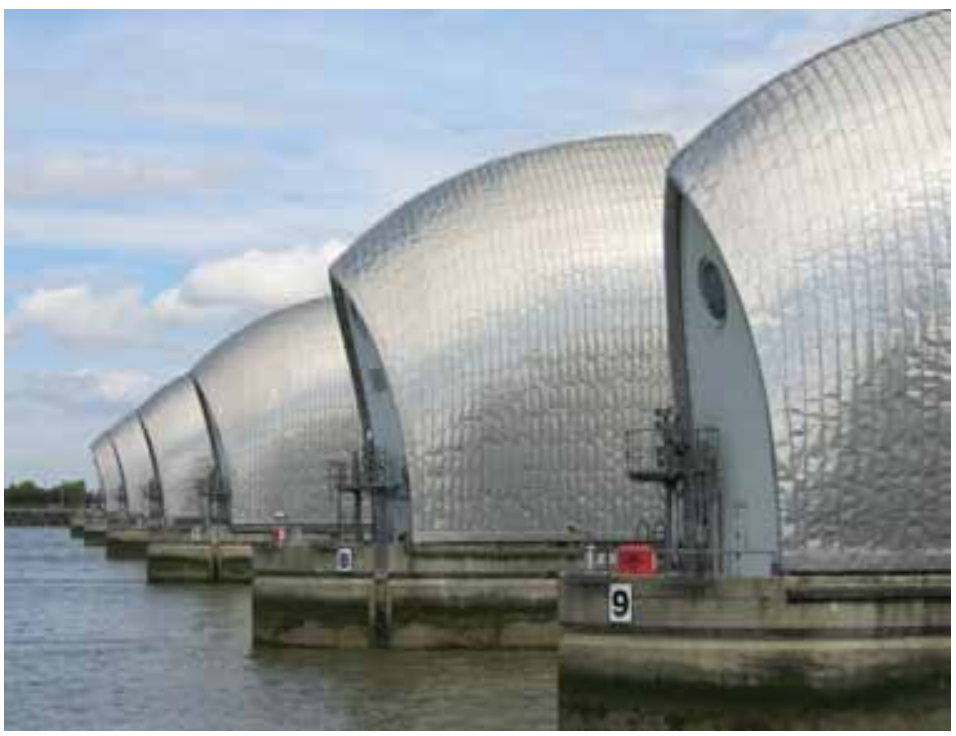

Fig 4.2 Thames Estuary Barrier

The TE2100 Thames Gateway area includes the Thames Estuary, its tidal tributaries and floodplain. It covers about 500,000 homes and 40,000 non-residential properties. (The Association of British Insurers (ABI), July 2009). 
risk management strategy for the region surrounding the River Thames'. This strategy has been developed as follow-on from the Thames Gateway Design Pact (2008) described in the previous chapter. Along with a new system of floodgates to assist the barrier, ten estuary-wide options for flood risk management have been devised and tested for effectiveness and efficiency, with a programme of construction from 2010 to 2069. From 2070, options diverge and another scheme will be put in place. The strategy sets out various standards and approaches to development along the river, to ensure the delivery of high-quality public and private spaces in the Thames Gateway.

\subsubsection{CLEVELEYS SEA WALL, LANCASHIRE, ENGLAND}

In 2004, the local council of the seaside town of Cleveleys in Lancashire, England, commissioned a complete redesign of a battered and unsightly sea wall. The sea wall was seen as isolating the sea front from the town, and contributing to Cleveley's loss in tourism revenue to other seaside towns that offered higher quality urban environments (Smulian, 2008).

The new wall (fig 4.3) has been accredited as successfully protecting the town from the predicted effects of climate change (up to a $200 \mathrm{~mm}$ sea level rise), and creating a high quality promenade with successful urban qualities (CABE, Cleveleys New Wave). It is now known locally as 'the people's promenade' (Civils, 2007). The improvement has encouraged private investment and has allegedly linked the town successfully with the seafront (CABE, Cleveleys New Wave). The design has won many awards, including The Urban Renewal Award (2007) and The National Constructing Excellence Awards - Project of the Year (Cleveleys Sea Defence Works, 2007).

Improvements that have contributed to a better quality urban environment along the seafront include street 'furniture', a pavilion building, spaces for public art, lighting systems and exhibition spaces. The promenade has been widened and landmark shelters provide a focal point at ends of roads leading to the waterfront, attract pedestrians, and provide wide views of the sea. Revetments, consisting of wide public steps, are designed so that damage from sea surges remains localised, while maintaining an 'open feel and access to the beach' A large semi-circular terraced performance area forms a strong feature at the south end, and tall wind turbines add character to the promenade's northern end (CABE, Cleavelys New Wave).
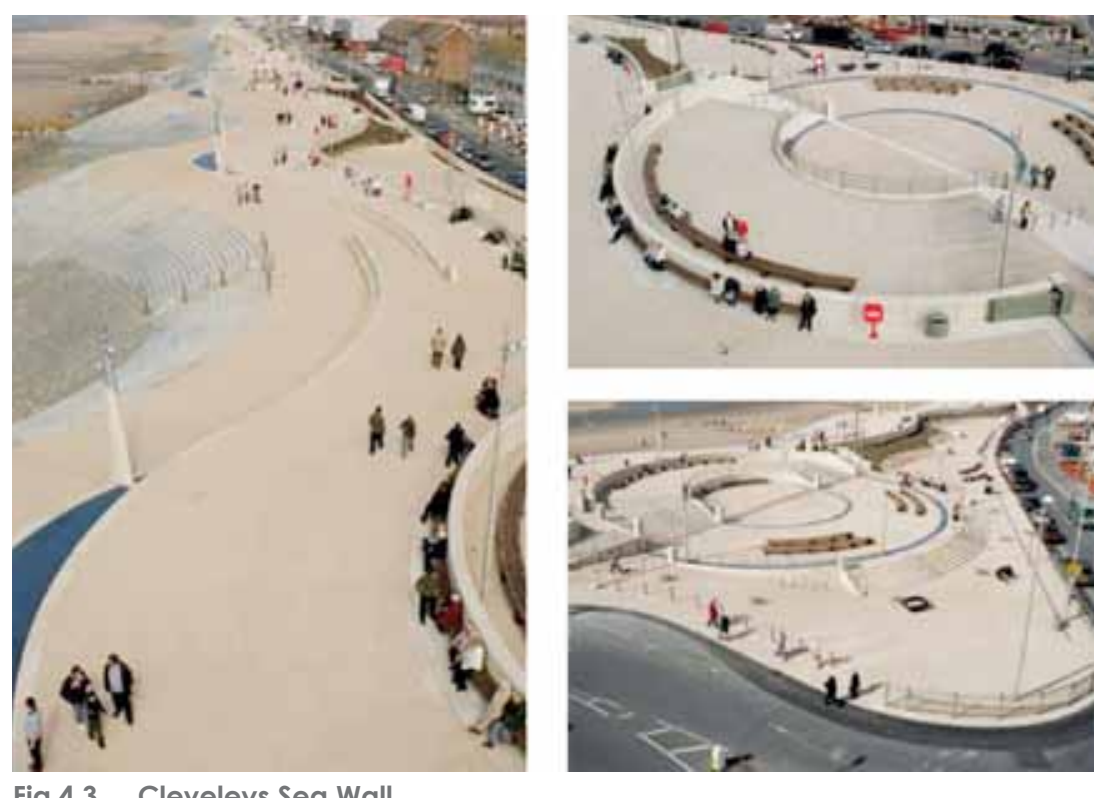

Fig 4.3 Cleveleys Sea Wall 
Public participation has been encouraged throughout the design stages of the project. Public ideas were incorporated into the brief for the design competition, and members of the public were invited to comment on the proposals put forward for the masterplan competition. The council has stated that involving the public and gaining local support was fundamental to the promenade's success (CABE, Cleveleys New Wave).

\subsubsection{DISCUSSION}

Protection is often seen as the obvious solution to erosion and sea level rise. Issues include high ongoing costs, adverse effects on beach systems, and feasibility of maintaining protection over large areas of retreating shoreline long-term (Turbott, 2006, p. 2). In some cases, sea walls have contributed to erosion rather than preventing it (Bell, 2002, p. 15). Impediments to visual and physical connections between city and water may arise if urban design qualities have not been considered, and if the wall has been designed purely from a mechanical perspective. However, Cleveleys Sea Wall case study shows how with proper understanding and care with design, a seawall can contribute positively to the public realm and become a 'place' rather than simply a barrier between a city and the sea.

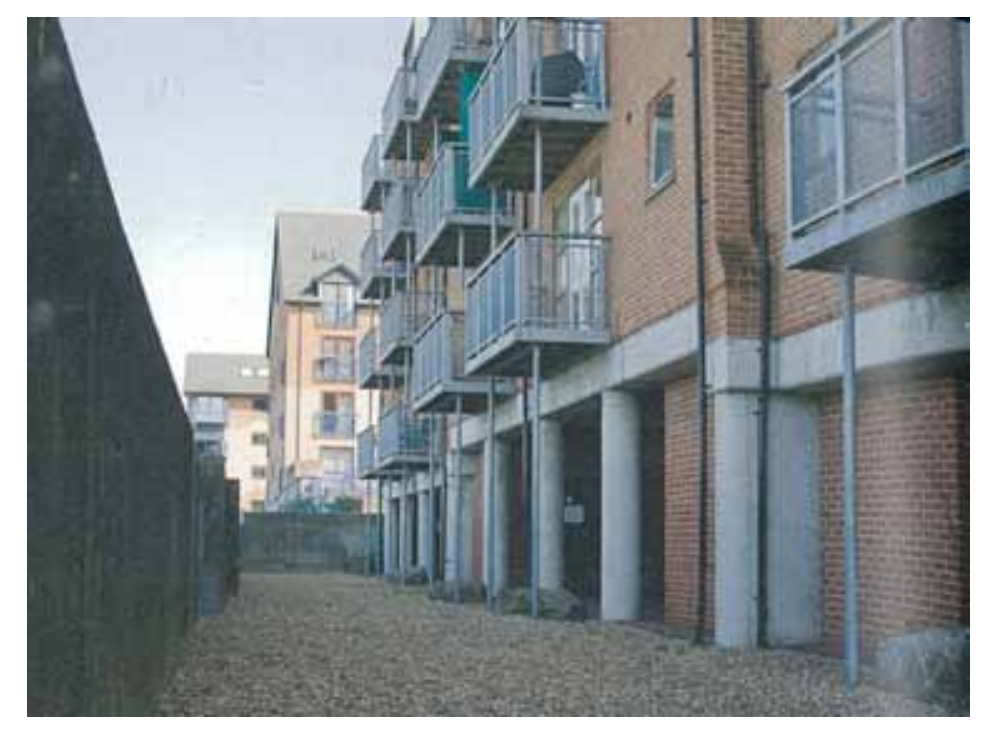

Fig 4.4 Sea Wall in Northampton, Britain

Flood defences can create unwelcoming public spaces 
Accommodation is the continued occupation of coastal land while making adjustments to urban infrastructure and/or lifestyle. Accommodation strategies may include redesigning existing structures; implementing legislation to encourage appropriate land use and development; or enhancing natural resilience through coastal dune and wetland rehabilitation (Warren, 2007). Accommodation may change the function or form of conventional buildings and infrastructure, or change the way in which people live and interact with the water.

The following case studies focus on emerging development towards floating urbanisation within the Netherlands. One development adapts conventional house construction to withstand periodic flooding, and the other uses water as a base for construction. Floating urbanism is an important trend to investigate because, as water levels are kept constant relative to the buildings, urban life can continue to function whatever the height of surrounding waters .

Two-thirds of the Netherlands would be inundated if there were no dikes or coastal protection (Anderson, 2009, p. 54). Despite the threat of water, the Dutch continue to reclaim land and populate areas at risk of flooding.

If sea levels rise dramatically, historic defence methods in the Netherlands will become ineffective. There is an urgent need to mitigate the risk of flooding, while, at the same time, expand settlements on vulnerable land.

Floating homes are developing from individually-owned houseboats in city rivers and canals to industrial-scale construction. Floating buildings have become movable and removable: adaptable to differing land formations and water-bound conditions. The following case studies are examples of this advancing technology.

An Amphibious house is a normal house designed to float above its foundations in times of flood. As it is a relatively new concept, construction methods are still being investigated and improved.

An amphibious housing project currently in construction is in Maasbommel, designed by the architectural team Dura Vermeer. Thirty-two amphibious houses have been constructed so far
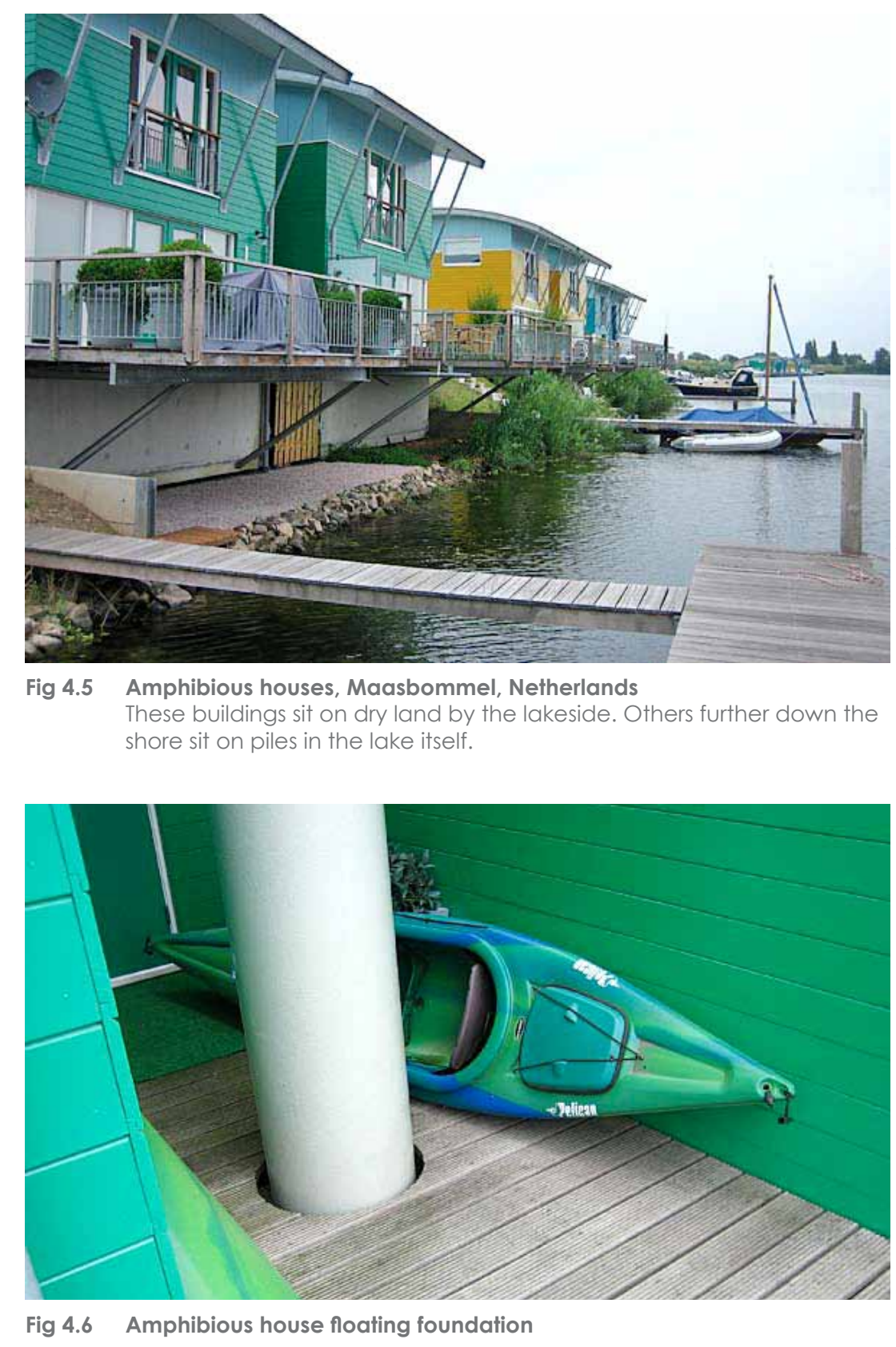
(Mörs, Mariska). This is an integrated concept that combines local water supply, local energy supply and floating urbanism.

Each unit is composed of a house on a concrete foundation, resting on a second, floating foundation. During normal conditions the house works as any other. During times of flooding, the construction will float above ground by sliding along two mooring poles at the front and rear of the building. With flexible PVC piping, plumbing, electrical, and natural gas connections also move with the house, which can accommodate a difference in water level of up to 5.5 metres (Zevenbergen). The houses have a wooden frame construction in order to be as light as possible (Palca, 2008).

It is expected that rising water in the Maasbommel flood plain will cause the houses to lift off the ground once every five years. In this development all the buildings are similar: two storeys high, with semicircular metal roofs and yellow, green or blue facades. Amphibious buildings are relatively expensive compared to a normal Dutch family home (Palca, 2008).

\subsection{2 'NEW WATER' FLOATING BUILDINGS, NALLDWIJK}

New Water, to be completed in 2017, designed by the Dutch architectural team Waterstudio, will be the first floating development in the country (Waterstudio, New Water, Naaldwijk, 2010). It is a benchmark Dutch floating urbanism development, making use of water as a regulated and structured element in street plans (Fransje Hooimeijer, 2005, p. 17).

The New Water development aims to flood an artificial landscape that has been kept dry using water pumps for the last 200 years. The site will act as a regional contingency water storage area and will host water related developments. With over 12 residential units per hectare, the $820,000 \mathrm{~m}^{2}$ development will use virtually all water based concepts and technologies: floating houses, floating islands, floating roads, floating gardens, stilt-houses and terp-houses (Waterstudio, New Water, Naaldwijk, 2010).

Construction of the first modular-unit apartment complex, named 'Citadel', began in March 2010. The project consists of 60 apartments, each with garden terrace, view of the lake, and berth for a small boat. A small floating road connects the apartment complex to the mainland, with space for resident parking and emergency vehicles (Waterstudio, The Citadel, 2010).

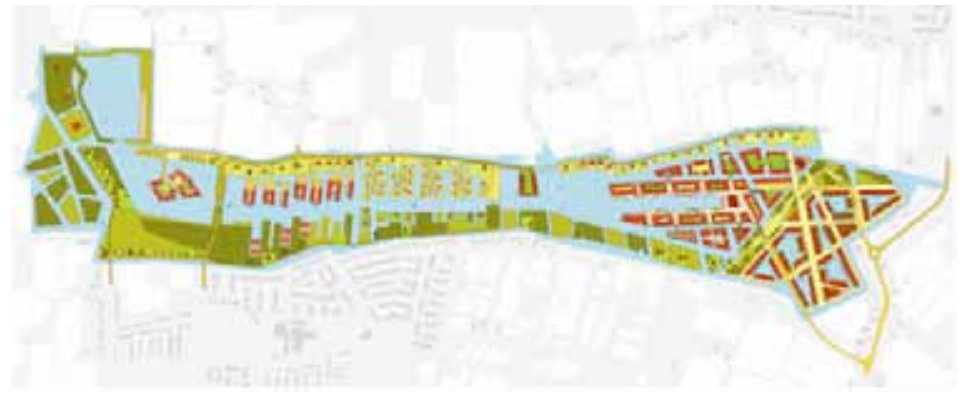

Fig 4.7 New Water

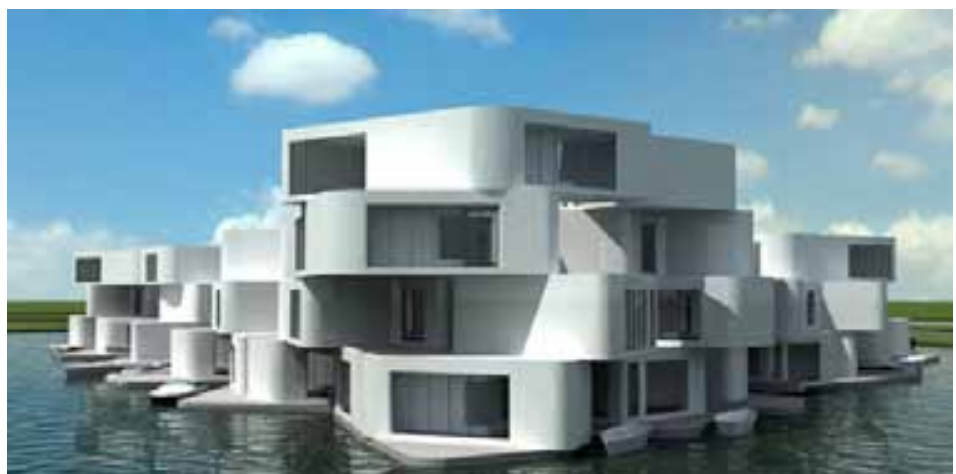

Fig 4.8 Citadel 
Water based buildings remove the need for hard flood defence protection around residential areas. Currently, all realised floating projects are small residential buildings located on the embankments of rivers, lakes and canals. There is no 'city' as such, and the buildings are entirely dependent on land-based infrastructure. As a flexible and reversible building solution for the future, floating urbanism provides designers and planners with an effective means of increasing population density while offering a variety of design options for a varying land/water environment.

As this is an emerging industry, there is still much to be learned, as structures must stand the test of time to be successfully evaluated. The presented case studies represent current understanding and practice for amphibious buildings that sit alongside or on fresh water canals or rivers. There is far less development around harbours or out to sea. Also, current activity is geared towards freefloating buildings, rather than floating districts or cities. New technology is needed so that functions can be executed independent of the land. New insights are also needed into behaviour and perceptions of people living and working on and around water (Urgenda, 2008).

The case studies show it is possible for a protection measure to become a positive urban entity, and that public participation is crucial. The first case study focuses on a number of separate landbased houses that are designed to float in floods. The second case study is a permanently floating apartment complex.

Lack of local experience and knowledge could impede effective implementation of floating buildings in Wellington City. Without local precedent or 'code of practice' the idea seems farfetched. Questions such as, 'Who owns the water?' or, 'Where can/can't one build?' will need to be answered. Before discussion enters the public forum in Wellington, essential planning elements must be resolved including vehicular and pedestrian connections, fire access, water quality assessments, and potential infrastructure planning.

The success of these protection measures should continue to be observed to determine the best process for Wellington. 
Retreat is the choice to evade risk in order to remove a direct impact. Land that is threatened by corrosion or sea level rise is either abandoned when conditions become intolerable, or not developed in the first place. Often referred to as 'managed retreat,' the term does not appear within either the Resource Management Act or the New Zealand Coastal Policy Statement (Turbott, 2006, p. 4), yet it is a model commonly used internationally.

Traditionally thought of as the 'last option', Retreat is most often used where land is low in value and is less developed. Retreat does not always imply completely passive response, as when applied to urban areas, it is often necessary to reconstruct the water's edge.

Common mechanisms for managed retreat are setbacks that require new development to be a minimum distance from the shore, density restrictions that limit development, and rolling easement policies that allow development on the condition that it may be removed later to enable wetlands to migrate landward (McCarthy, 2001). Other procedures include conditional phasedout development, withdrawal of government subsidies, and denial of flood insurance (McCarthy, 2001).

As retreat has rarely been used in urban areas, the following case studies are examples of schemes that involve small settlements. Each has used a different method of implementation; one has been unsuccessful in gaining support from homeowners, while the other has achieved relocation of all affected homes.

\subsubsection{BYRON BAY, NEW SOUTH WALES, AUSTRALIA}

Byron Bay, a popular resort on the New South Wales coast, has been pinpointed as a location where an engineering solution is not physically possible, and planned retreat has been proposed. In 2009, the Byron Shire Council published a planning policy advocating planned retreat, and is putting steps in place to allow natural erosion of coastland. Homeowners are now prevented from constructing physical defences, and hundreds face the prospect of forced demolition of their homes. This will be the first time in the state of New South Wales that planned retreat will be imposed on existing dwellings under state law (State, 2009).

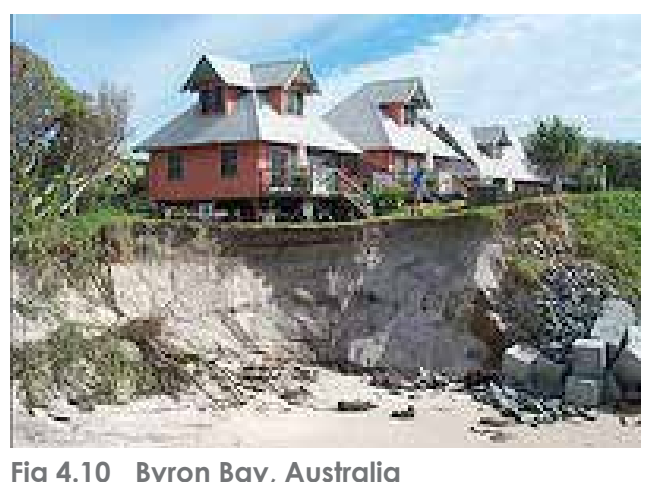

Fig 4.10 Byron Bay, Australia

Erosion on Belongil Beach at Byron Bay 
This intervention policy was described as 'lunacy' by opposing homeowners (State, 2009), and what has been described as a 'war' (Anonymous, 2009) broke out between the Byron Shire Council and the Bay's residents. The council is involved in legal battles with multi-million dollar property owners, who are fighting for the right to individually defend their properties from coastal erosion caused by storms and engineering works (Fyfe, 2009). The council argued that the property owners' walls will exacerbate erosion of the beach, eventually making it disappear.

The Council's 'highly politicised approach' has caused damage to the area's tourism industry and property values (Evans, 2009). In October 2010, one of the properties affected by the 'planned retreat' sold for $46 \%$ of its last sale price (Johnstone, 2010). ${ }^{2}$

The policy requiring property owners to uproot has been disastrous for the relationship between Council and Byron Bay residents. Community participation was inadequate throughout the decisionmaking process, and no design relating to the proposed retreat has yet been implemented. Compensation to the owners of 'lost' property and collective benefits has not been made clear. However, the challenge to the regime has triggered local and national discussion on the future of many coastal towns around Australia.

Project Twin Streams is a 10-year urban sustainability project based in Waitakere City, which aims to restore $56 \mathrm{~km}$ of Waitakere stream banks through an integrated community development initiative. Waitakere City Council has successfully purchased and removed 156 full and part properties located within the 100 year flood plain. ${ }^{3}$ The method adopted by the project reinforces the International Agenda 21 Approach, which implies that if people understand the problems, and are involved in the solutions, the uptake is likely to be much more successful (Atlas Communications and Media, 2010, p. 1).

The objective for Project Twin Streams was to purchase the required properties with minimum opposition by using a process that would achieve community buy-in. The overall process was designed to ensure that all affected property owners understood the issues affecting their locality in order to be 'more likely to sell their homes' (Atlas Communications and Media, 2010, p. 6).

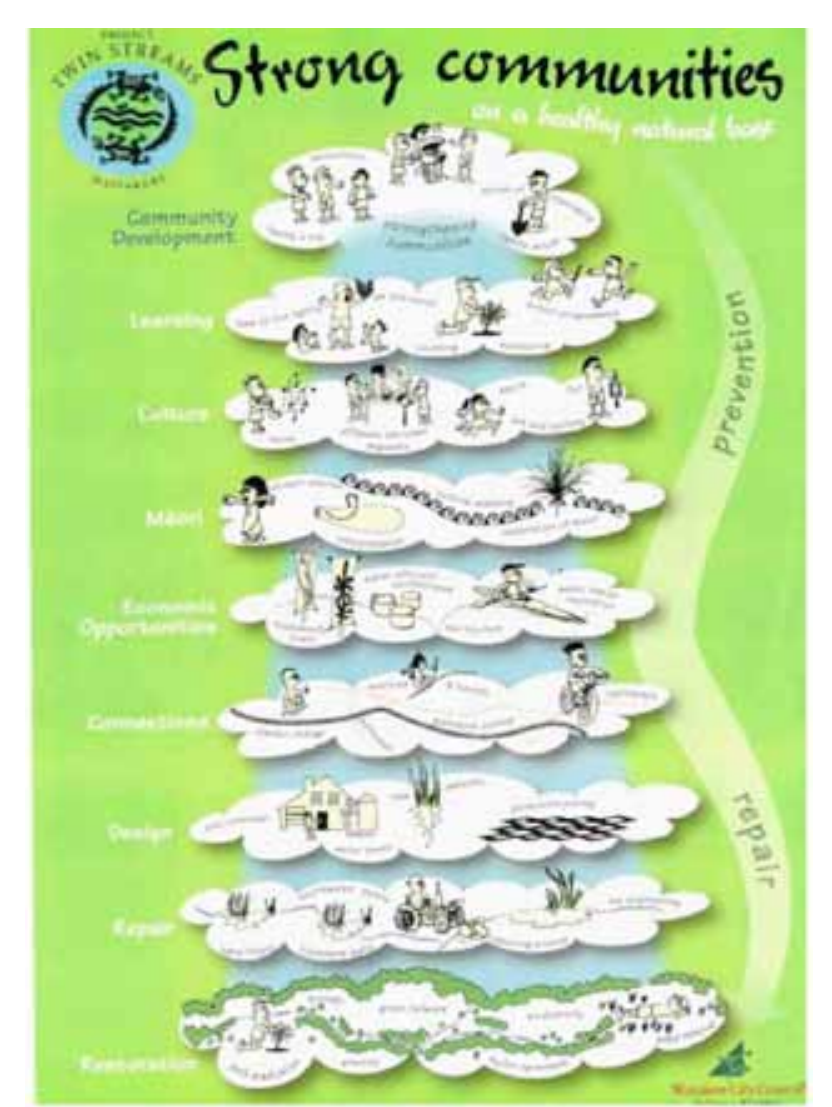

Fig 4.11 Project Twin Streams: Key objectives, the 'Nine Clouds' The Nine Clouds diagram provides the public with a visual picture of objectives and activities of Project Twin Streams.

This dramatic price cut reflected official valuations for the property, which fell from $\$ 4.7$ million in 2008 to $\$ 2.29$ million in 2009. The Valuer General for Byron Bay noted the strip's decline was a response to the lack of demand caused by coastal erosion and the global financial crisis. (Johnstone, 2010)

3. 
Project leaders came from a mix of disciplines. Running on a strict time frame from 2003, they aimed to engage the local community and build a sense of ownership over the matter (Waitakere City Council, 2009). Local people became aware of what was proposed through regular meetings, brochures, letters, feedback forms and visits to key agencies and community groups (Trotman, 2005). 'Community planting days' were organised help restore the stream: the public was invited to weed plants, remove rubbish, and design habitat for relocated native fauna (Project Twin Streams, 2010). Land within the floodplain was restored, and recreational facilities, walkways and cycle routes were built.

In 2007, the property purchase project received international recognition as a finalist in the International Thiess River Prize (Waitakere City Council, 2009). The success of this project has been awarded to 'meticulous and detailed planning subsequently well executed by a handpicked project team, who were also well resourced in terms of training, time and budget' (Atlas Communications and Media, 2010, p. 2).

\subsubsection{DISCUSSION}

Aside from Waikatere Project Twin Streams, retreat in New Zealand has been involuntary, rather than strategically planned (Bell, 2002, p. 15). Abandoning the shore is impractical for coastal communities in New Zealand, and unpopular with seafront property owners. Much of the loss caused by retreat is borne by the individual property owner; and there is potential merit in compensating them. The relative success and failure of the aforementioned case studies illustrate how important it is to involve the community in all stages of the decision-making process.

Retreat in Wellington City is problematic for a number of reasons. Much of the city's most valuable assets are concentrated near the waterfront, making it quite unlikely that landowners would agree to give up their properties if protection of their property was possible. Most urban infrastructure is immobile and enduring, which would make rapid shifts in urban relocation very costly (Jane Bicknell, 2009, p. 54). New homes, infrastructure and transportation routes would need to be built quickly, possibly on mountainous land, which risks expense and poor quality construction. Larger companies and households could easily adjust and move offices, production facilities and homes away from cities or areas of risk, however those less wealthy could not (Jane Bicknell, 2009, p. 369).

The authors of Adapting Cities to Climate Change (2009) recommend that before policies involving retreat are put in place, a better understanding is needed of why urban settlements in coastal areas are growing more rapidly than inland. They state:

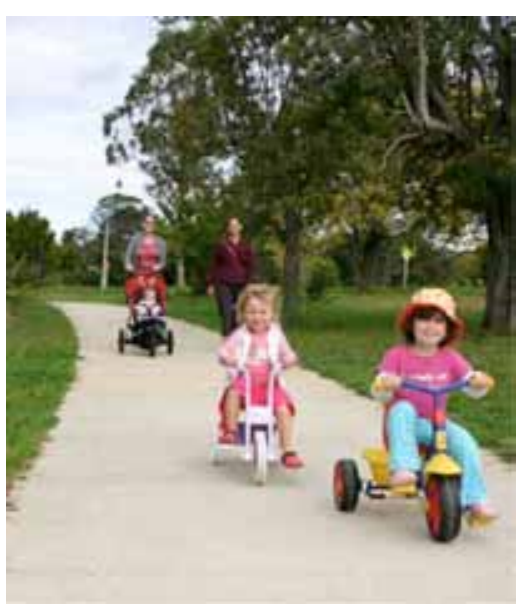

Fig 4.12 Waitakere's new cycle and walkway $14 \mathrm{~km}$ of public cycle and walkway were built along the streams

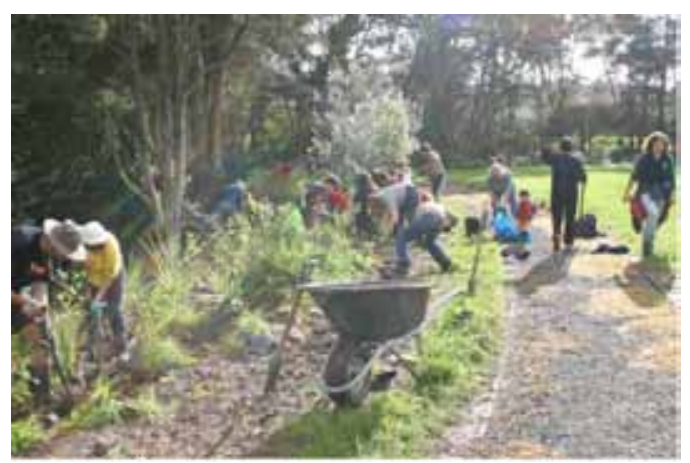

fig 4.13 Community planting days

Planting days acted as a means to connect people to the project, and helped to give the community a sense of ownership of the area

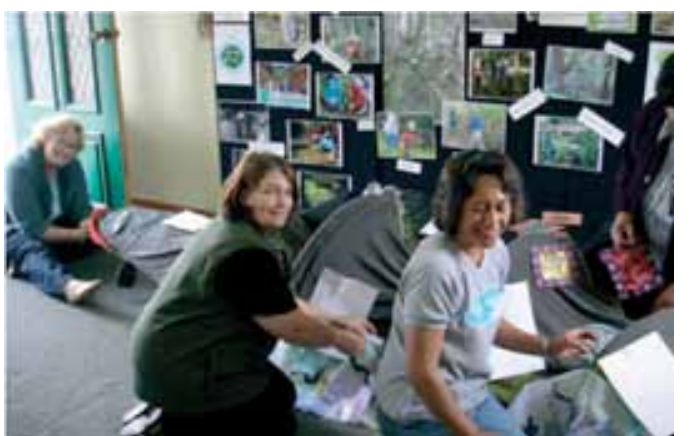

Fig 4.14 Communication and relationship development Educational get-togethers sustained community interest and involvement in the project 
Small shifts in settlement location, out of a coastal plain into more elevated ground, can make a major difference. However, there are profound difficulties involved in instituting more restrictive coastal settlement policies without further undermining the lives and livelihoods of the most vulnerable residents.

(Jane Bicknell, 2009, p. 54)

Retreat can be an option in particularly vulnerable parts of cities. Policies restricting further development could be implemented when planning future development in vulnerable areas. By containing development in less at-risk zones, disaster recovery and long-term disaster prevention and preparedness could be combined (Richard J.T. Kleina, 2003).

4.4

More research is needed to determine the most effective forms of response to sea level rise. As every coastal city will be affected differently, decision-making processes must be locally-based. Risk prioritis ation must be balanced against hazard management and other community needs. As process proves likely to be just as important as physical design, it is important to involve the community throughout all stages of design.

A large component of Wellington City is already defended by sea walls (see fig 4.15), a culturally accepted, structurally sound and stable method of protection. Given the large number of residents and financial assets that they defend, there will no doubt be resistance to 'retreat' as the only response to sea level rise. A working response is likely to involve all, or a number of the strategies described.

Knowledge of up-to-date technologies and the successes and weaknesses of existing solutions to the problem of sea level rise is needed prior to designing a suitable reponse for Wellington City. Wellington's environment and culture are however quite different from the models described. A response for Wellington City must also take into account its context.

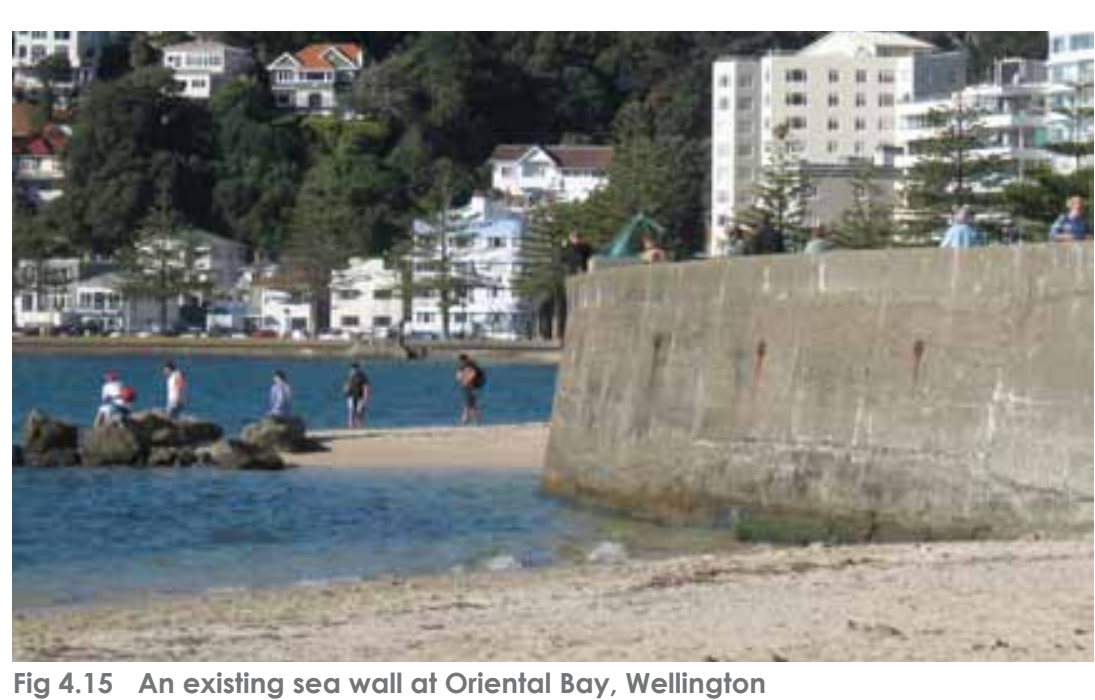

Fig 4.15 An existing sea wall at Oriental Bay, Wellington 


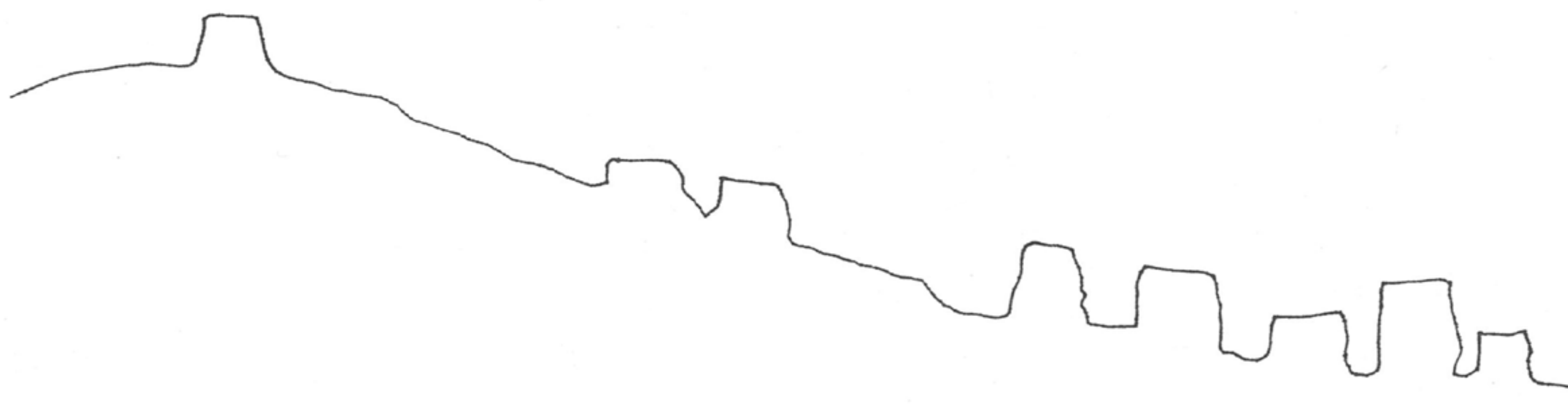




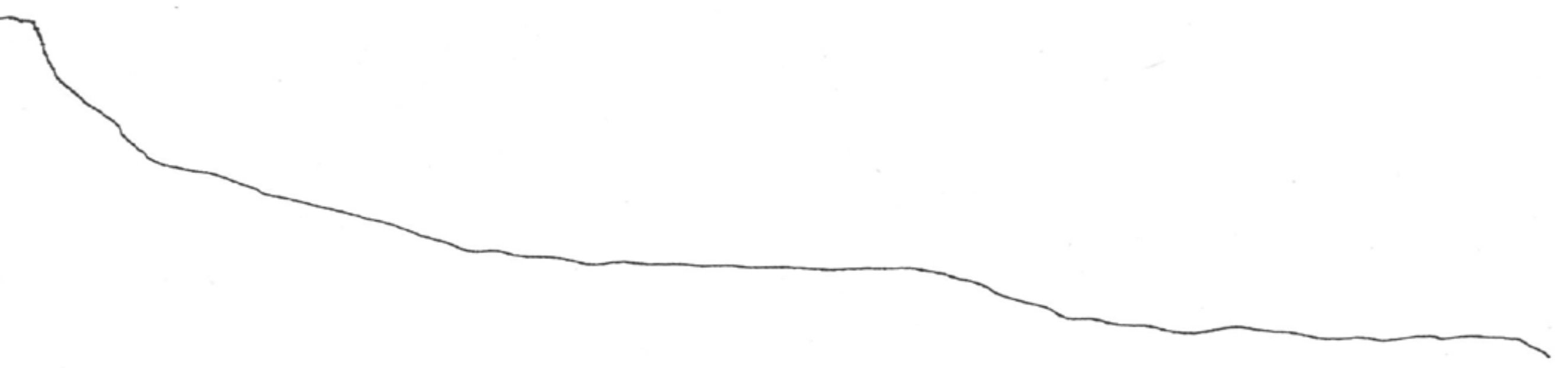

Chapter Five:

Wellington 
Urban design response to sea level rise in Wellington Central City and waterfront should be in the context of its history and culture, and the quality of existing buildings and public spaces. Specific sea level rise predictions have been made for the city and there is current legislation of relevance.

To understand implications of sea level rise and to design an effective urban design response, it is necessary to consider the context of a site, i.e., its relevant culture, history, and current design directive and legislation.

\subsubsection{THE SEASIDE AND COAST: KIWI CULTURE AND LEGISLATION}

New Zealand is an island nation. The ocean has been inextricably linked to its natural and human histories. Sixty-five percent of the population lived within $5 \mathrm{~km}$ of the coast in 2006 and $75 \%$ within $10 \mathrm{~km}$ (Statistics New Zealand, 2006). New Zealanders regard their coastline as a public asset; available to everyone, irrespective of property ownership or wealth. However, the well-known 'Queen's chain'", a 20-metre marginal stripalong most waterways of New Zealand, is an outdated concept. ${ }^{2}$

For Maori, the aboriginal people of New Zealand, the coast is intertwined with spirituality and identity. Maui, a popular figure in Maori legend, was thrown into the sea by his mother, who believed him to be stillborn. The god of the ocean preserved and nourished him until he grew strong with magical powers (Wilson, 1932, p. 76). When he was older, legend tells us he fished up the North Island, called Te Ika a Maui (the fish of Mavi), from the sea. Wellington, (Te Upoko o te lka) was the head of that fish (Raewyn, 2009, p. 13).

Over the past two decades there have been substantial changes to New Zealand coastal management. In 1991, The Resource Management Act made public access and maintenance of the coast and other waters matters of national importance. The Act applied a more flexible definition of the Queen's chain. Preservation and maintenance of esplanade reserves became regional and city councils' responsibility (Raewyn, 2009, p. 169). These territorial authorities operate on a loose statutory framework, and are subject to local political pressure from landowners and developers. chain (20 metre) width of the reservations and from Queen Victoria's Instructions to reserve land in public ownership near the seacoast or navigatable streams. The 'Queen's Chain' is comprised of segments of marginal strip, public road, and esplanade reserve. These provide public rights of access over approximately 70 per cent of our shores. (Recreational Access New Zealand, 2003) 1987, are normally established at the time of the Crown disposing of adjoining lands to private interests. Marginal strips are owned by the Crown or a local authority and usually available to the public for recreationat purposes. (Storm, 2002) 
The belief of most New Zealanders that the coast should be accessible to everyone became fiercely challenged during the seabed and foreshore debate in 2004. The misguided perception that Maori would obtain sole ownership of certain beaches resulted in public backlash leading to a hikoi (protest march) and subsequent formation of the Maori Political Party. Rapid government legislation - The Foreshore and Seabed Act - attempted to balance public interest and Maori customary rights. The Act ensured public ownership of the New Zealand coast beneath high tide, and recognised a limited number of Maori customary rights (Raewyn, 2009, p. 167). Debate continues today, as many Maori see the Act as deliberate confiscation of land rights without satisfactory compensation.

\subsubsection{WELLINGTON HARBOUR'S HISTORY}

Wellington's harbour has been inhabited since the $10^{\text {th }}$ century. It provided settlers with food, shelter, recreation, communication, and transportation and has been a working port and centre of activity since early colonisation (Waterfront Leadership Group, 2001, p. 12).

The first wharf was constructed in 1845 for the Wallace family (Anderson, 1984, p. 102). Since then, the shoreline has constantly changed. In the 1850s, major reclamation of the foreshore was begun, to assist mercantile expansion and trading (Waterfront Leadership Group, 2001, p. 12). In 1855 an earthquake raised the beach in front of Lambton Quay by over a metre (Raewyn, 2009, p. 44), and dramatically flattened adjacent land. Queen's Wharf was built not long after the establishment of Wellington as New Zealand's capital in 1867, providing sturdy industrial buildings for visiting ships (Anderson, 1984, p. 164).

The area covered by this analysis is predominantly reclaimed land constructed in 1889, 1901-04, and 1967-70 (Wellington Waterfront Ltd (WWL)). Sea walls built in the late 1800s were constructed in almost a straight line from the bottom of Willis Street to Pipitea Point (Wellington Waterfront Ltd (WWL)), and remain to this day. By 1903 a continuous strip of sea walls of varying widths and styles guarded the shoreline from east Oriental Bay, along Jervois and Customhouse Quays, to upper Waterloo Quay (fig 5.3). The reclamation diagram (fig. 5.4) shows how land shape has changed over 150 years, and indicates sea walls (For more information refer to appendix 1).

At the instigation of Michael Fowler, Wellington's mayor, the 1970s marked a building boom within the city. An architect by trade, Fowler participated in city planning. He encouraged commercial development and the preservation of historic buildings in the central city. Fowler also endorsed

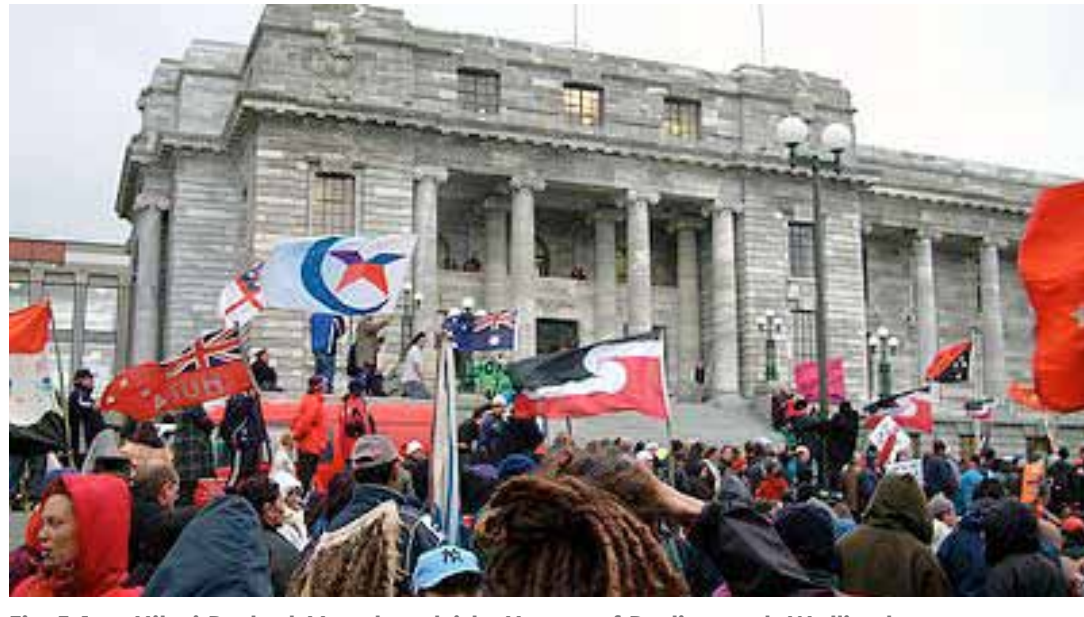

Fig 5.1 Hikoi Protest March outside House of Parliament, Wellington 

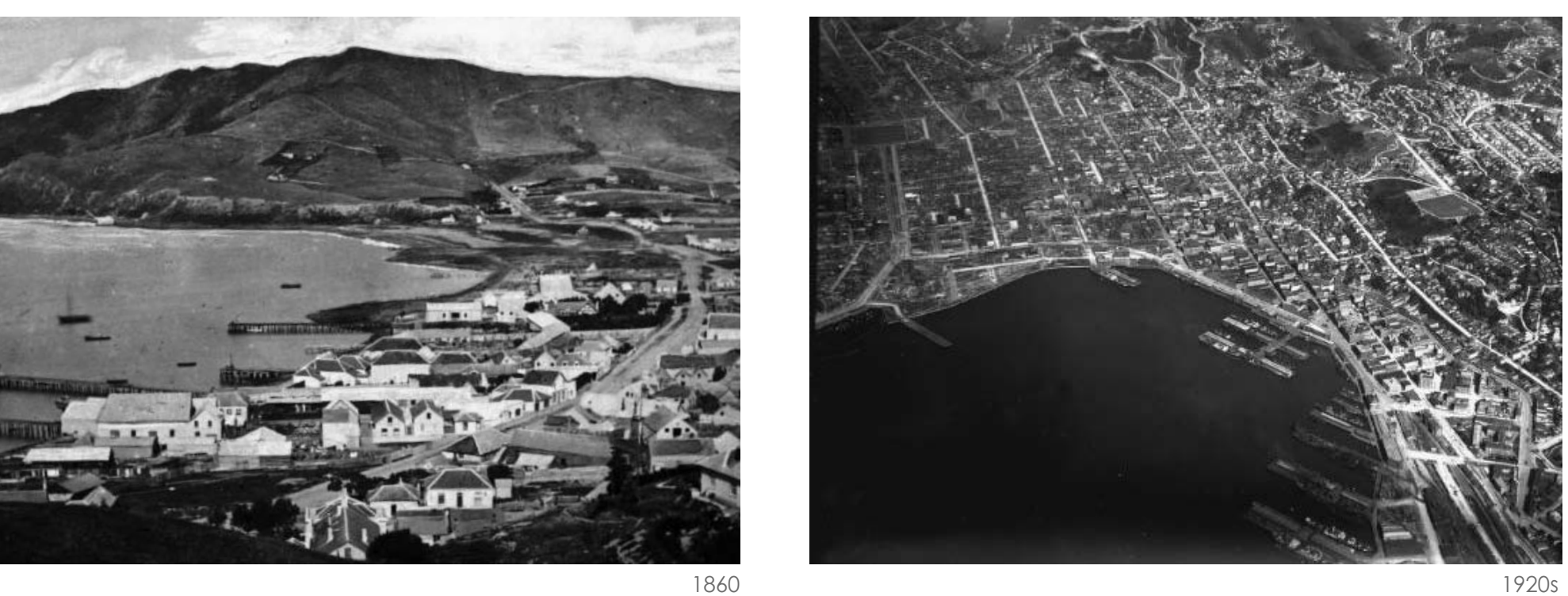

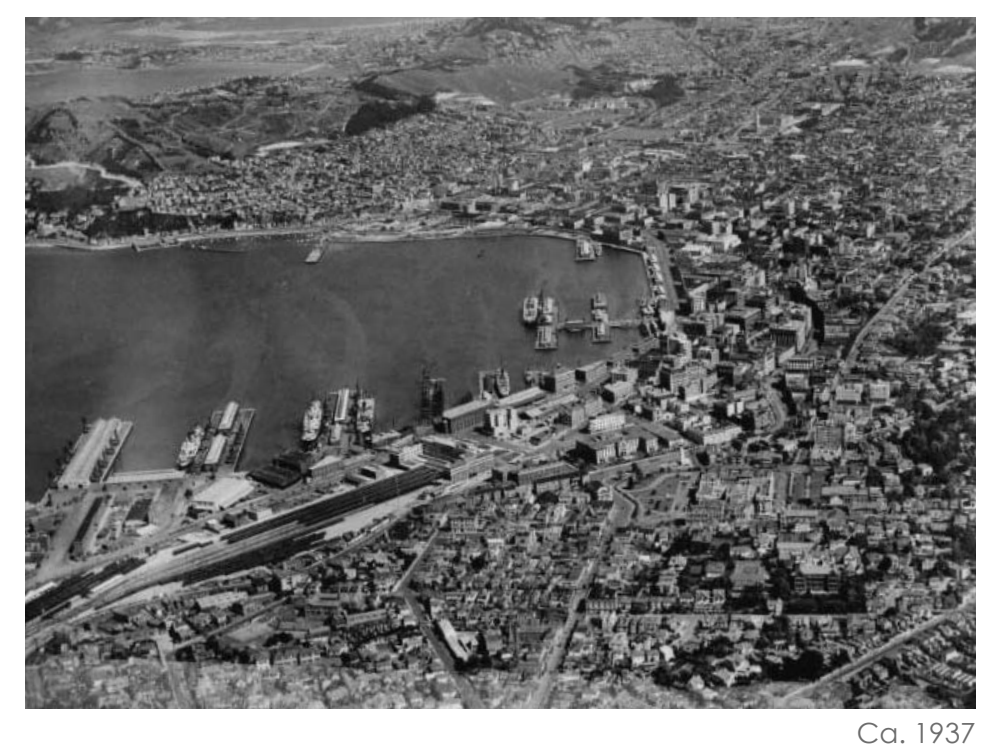




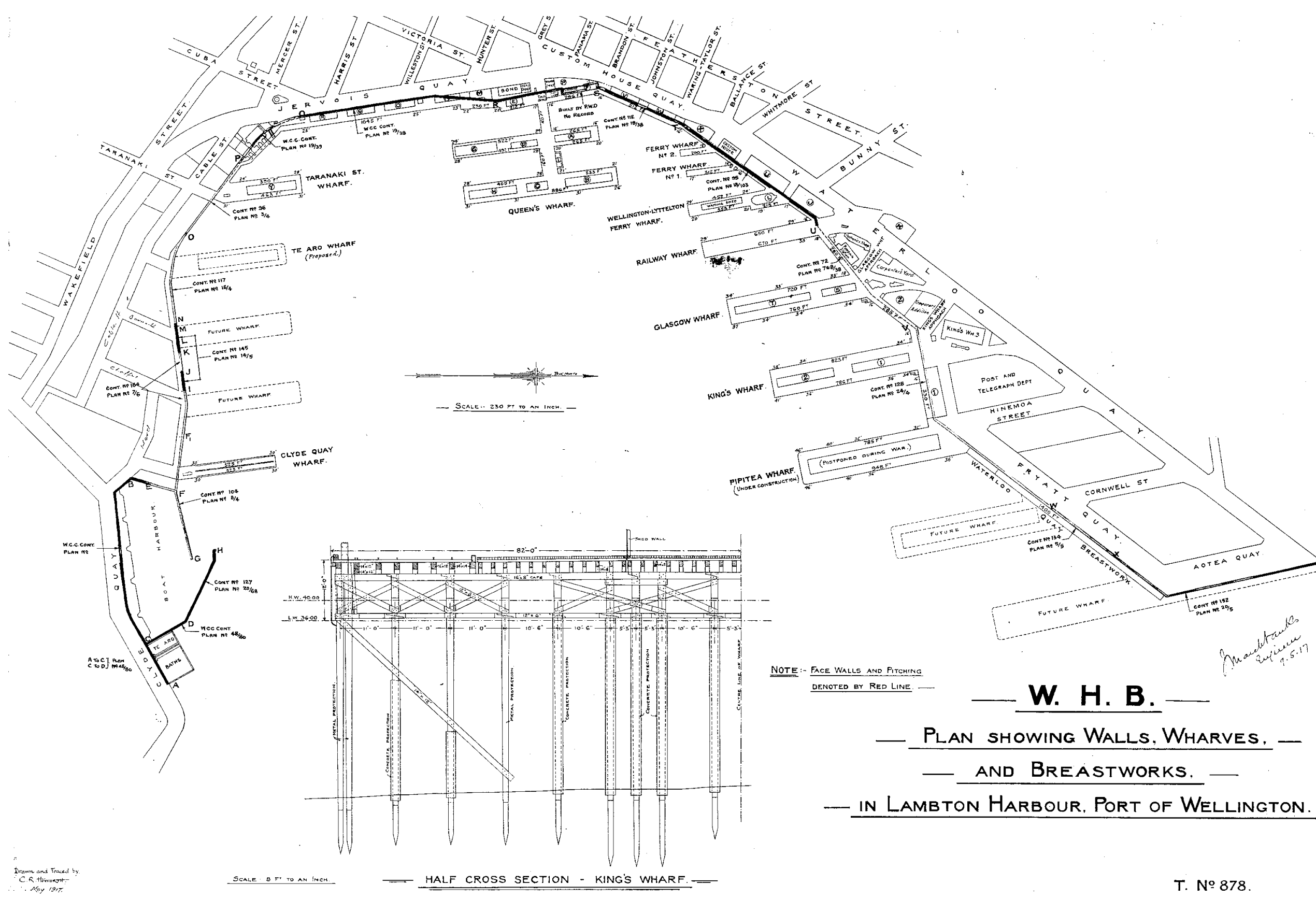

Fig 5.3 Sea wall plan 1917

Original drawing. Image reproduced with permission from Wellington Waterfront Ltd. 

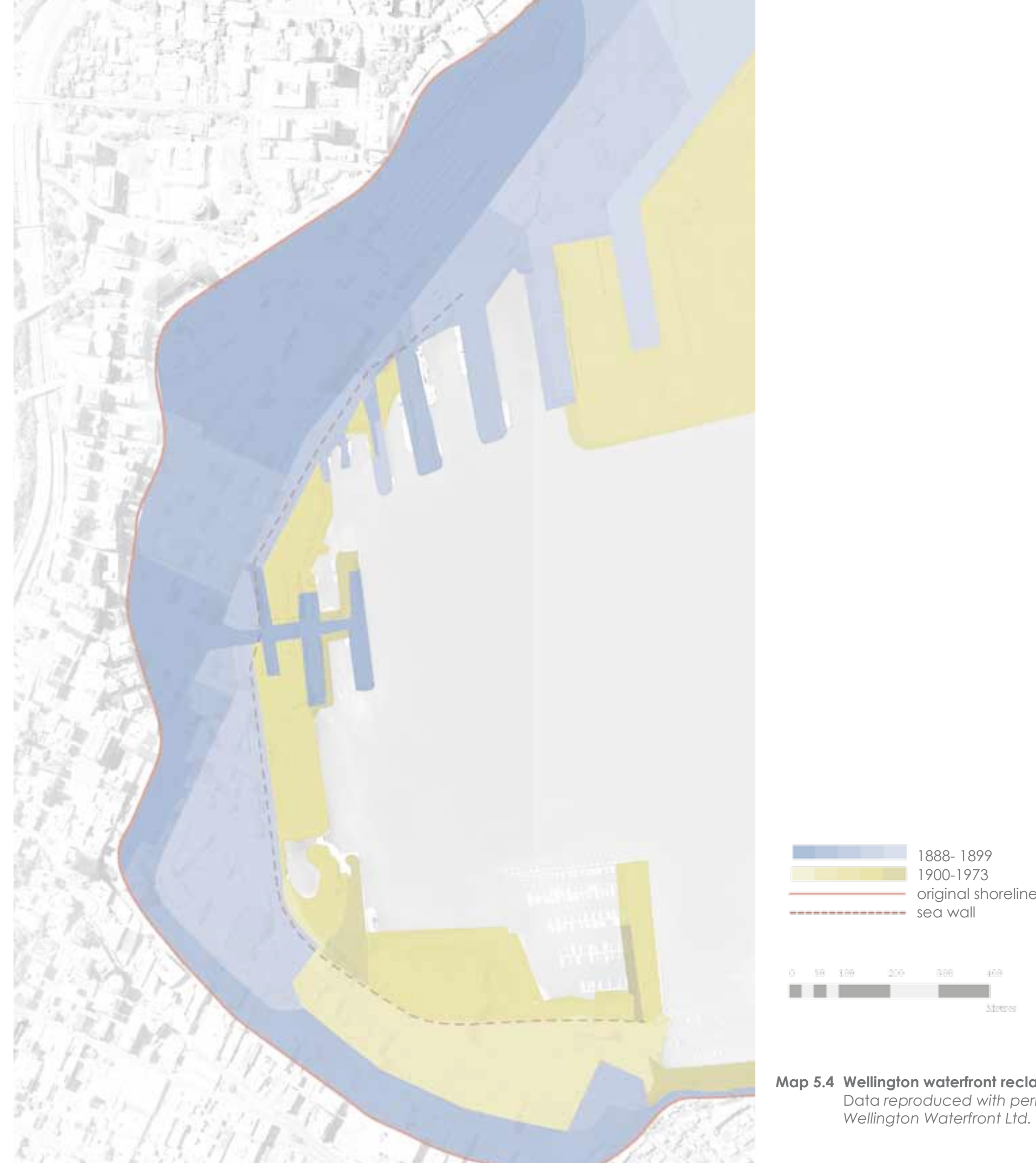

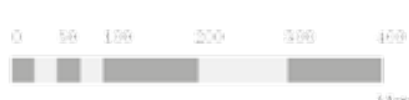


inner-city living, terraced housing and the retention of a 'civic centre' (McGill, 2003, pp. 252-5).

It was not until the 1980s that Wellington City Council begun to use the almost-vacant ${ }^{3}$ and extremely valuable waterfront land as public space. Mercantile trading activity was moved north and a number of significant harbour-front buildings were preserved (and sometimes moved). Developments such as Civic Square, City-to-sea Bridge and Frank Kitts Park in the early 1990s (McGill, 2003, p. 282) signalled a new focus on the importance of waterfront as public space.

The central waterfront is constantly developing, reflecting contemporary culture and recreation. It is now the city's principal public exposition and recreational space. Traces of mercantile history can be found in waterfront buildings, artefacts in city galleries and along the separate pedestrian and vehicular routes along the coastline. Recent high quality urban waterfront developments include the Museum of New Zealand [Te Papa] (1998), Waitangi Park (2009) and Kumutoto precinct (2010).

\subsubsection{DESIGN DIRECTIVE AND LEGISLATION WITHIN WELLINGTON CITY}

The Greater Wellington Regional Council (GWRC) covers eight territorial councils within its boundaries, including Wellington City Council. GWRC is responsible for the region's natural resources and environment. It is authoritative for all planning and resource consents the seaward side of the line of mean high water springs. ${ }^{4}$ below In co-operation with Wellington City Council, GWRC is responsible for road maintenance, land-use subdivisions and community services among others. Various Acts of Parliament such as the Local Government Act (2002) and the Resource Management Act (1991) provide the framework to enable GWRC's activities (Greater Wellington Regional Council, 2009).

The Wellington Region Strategy, developed by all the local authorities of the greater Wellington region, works in tandem with central government, businesses and voluntary sector interests to encourage sustainable economic growth. It aims to enhance 'regional form' by addressing issues such as transport, housing, urban design and open spaces. Its sub-agency Grow Wellington implements the economic initiatives of this strategy (Wellington Regional Strategy, 2010).

Wellington City Council is responsible for environmental health and safety, recreation and cultural activity, infrastructure, land-use planning, development control and resource management of the city (Local Government New Zealand, 2010). The District Plan - held by the council - aims to contain and encourage development and to enhance character areas in Wellington City (Wellington City Council, 2010). A 'Central Area Design Guide' provides framework rather than regulation for design, external appearance and siting (Wellington City Council, 2000, p. 2) of development had left their original port-side locations.

Mean high water springs is the average of the high tides that happen just after every new moon and every full moon. http://www.gw.govt.nz/restrictions-on-use-of-the-coastalmarine-area/ 
in the central city. The guide suggests how development can contribute positively, and provide standards or criteria for its assessment. It does not cover the waterfront area.

Regulation of the waterfront is somewhat different from elsewhere in the central city. Social, cultural and recreational activities, as well as existing buildings along the waterfront are fiercely protected. Wellington Waterfront $L t d$. is a council-controlled organisation that owns and manages the inner waterfront safeguarded by the following documents: The Wellington City Design Guide, District Plan Variation 11: Amendments to Proposed District Plan Change 48: Wellington Waterfront (2009); The Wellington Development Plan 2009/10; The Wellington Waterfront Framework document (2001); and its antecedent, The Waterfront Concept Plan. The recent Variation 11 (2009) concerns development in the Kumutoto precinct specifically. As a guideline, it aims to direct design of building alterations, new public spaces, and other new buildings within the area. Character of the area, pedestrian linkages and relationships between buildings are covered explicitly. (Wellington City Council, 2009).

\section{2} SEA LEVEL RISE

Wellington City needs to prepare itself for an eventual rise in sea level. The exact rate of sea level rise, and resultant consequences are so uncertain that the city must prepare itself for a number of possible scenarios.

\subsubsection{PREDICTIONS FOR WELLINGTON}

New Zealand is lagging behind global research and response option design for coastal cities (Chug, 2010). The New Zealand Ministry for the Environment warns that sea levels around New Zealand may not rise gradually, but instead exhibit stepwise changes (Ministry for the Environment, 2001, p. 15). The possibility also exists that New Zealand may exhibit sea level rises up to $10 \mathrm{~cm}$ above the global average (Bornman, 2010, p. 39).

Hazards posed by a median sea level rise will be relatively predictable. The dangers of larger storm surges and wave heights, more frequent and severe hurricanes, increased rainfall, and other changes in climate extremes are less predictable (Ministry for the Environment, 2001). Cyclone surges could add up to several metres to average sea level for periods of hours or days, and increase wave size and intensity. Strong winds and large onshore waves will add to the destruction. With respect to these additional hazards, design solutions must consider potential sea level rises higher than the $0.18 \mathrm{~m}$ and $0.59 \mathrm{~m}$ predictions of the latest IPCC report (Intergovernmental Panel on Climate Change, 2007, p. 8).

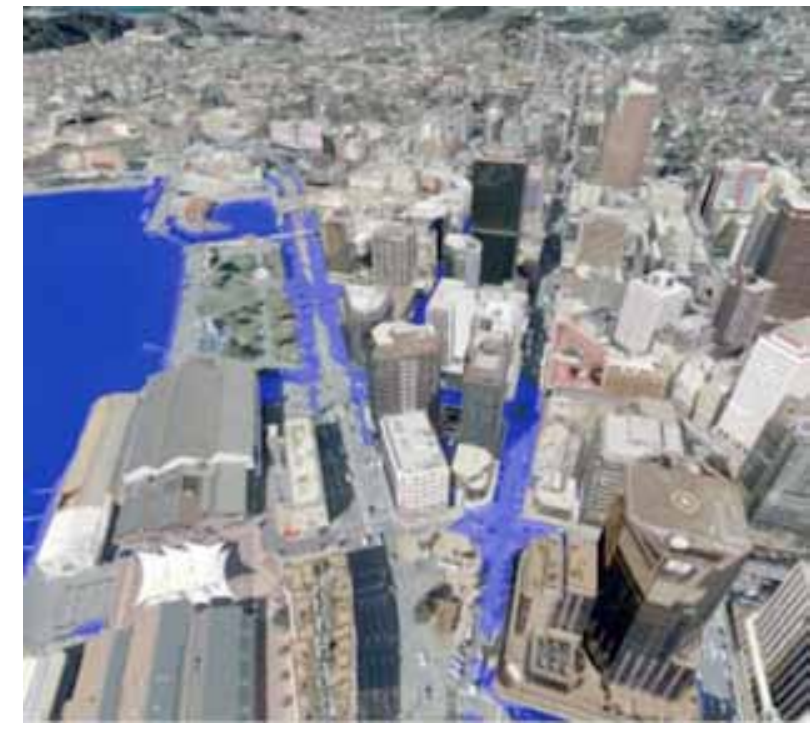

Fig 5.5 One metre sea level rise visualisation Produced for an article in the Dominion Post by the GIS operations team, Wellington City Council. (Devember 2009 
On a national scale the overall physical, ecological and socioeconomic losses and impacts of various stages of sea level rise are relatively unknown (RG Bell, 2001). New Zealand regulations and directives for sea level rise are currently minimal.

According to Raewyn Peart, author of Beyond the Tide, Integrating the Management of New Zealand's Coasts (2007), the New Zealand coastal management system is fragmented, having inconsistent objectives and approaches (Peart, 2007, p. 26). To date, there is no comprehensive, well-informed response to sea level rise for any New Zealand coastal city.

The Ministry for the Environment: Costal Hazards Climate Change Guidance Manual (2008) recommends to local authorities:

"Sea-level rise considerations within such a risk assessment are based on the IPCC

Fourth Assessment Report sea-level rise estimates, including consideration of the potential consequences from higher sea-levels due to factors not included in the current global

climate models."

(Ramsay, 2008, p. 20)

It suggests decision timeframes should extend to the 2090's, taking into account:

- A base value sea level rise of $\mathbf{0 . 5} \mathbf{m}$ relative to the 1980-1999 average should be used, along with

- An assessment of the potential consequences from a range of possible higher sea level rises... At the very least, all assessments should consider the consequences of a mean sea level rise of at least $\mathbf{0 . 8} \mathbf{m}$ relative to the 1980-1999 average.

(Ramsay, 2008, p. 20) 
The current New Zealand Coastal Policy Statement (1994) is significantly out of date, although it remains the principal guiding document for coastal management (Turbott, 2006). The policy states that Councils are responsible for identifying and monitoring natural hazards under the Resource Management Act (1991). It briefly mentions sea level rise:

Policy statements and plans should recognise the possibility of a rise in sea level, and should identify areas which would as a consequence be subject to erosion or inundation. Natural systems which are a natural defence to erosion and/or inundation should be identified and their integrity protected.

(New Zealand Government, 1994, p. 9)

The New Zealand Coastal Policy Statement (2008) is under review (Department of Conservation, 2010). This has a significant focus on sustainable coastal development. Sea level rise is recognised as a 'hazard risk' for new subdivisions, and is discussed more thoroughly than in the previous document (Department of Conservation, 2008, p. 25). Local Authorities are urged:

When considering the potential use of hard protection structures in response to coastal hazard risk, local authorities shall:

(a) Promote alternative responses, including soft engineering solutions and the relocation, removal or abandonment of existing structures;

(b) Take into account the expected effects of climate change, over at least a 100-year timeframe;

(c) evaluate the likely public costs and benefits of any proposed hard protection structure, and the effects on the environment, over at least a 100-year timeframe.

(Department of Conservation, 2010, pp. 25-26)

Wellington City Council has recently drafted a Climate Change Action Plan (2010) which recognises the vulnerability of parts of Wellington to sea level rise. The Plan states that scenarios for possible sea level rises are being used to plan future development of the city (Wellington City Council, 2010, p. 15). The Council has examined possible sea level rise scenarios for Evans Bay and Lyall Bay. To date, there has been no detailed analysis of consequences of sea level rise to Wellington Central City or viable long-term solutions for Wellington City. ${ }^{5}$

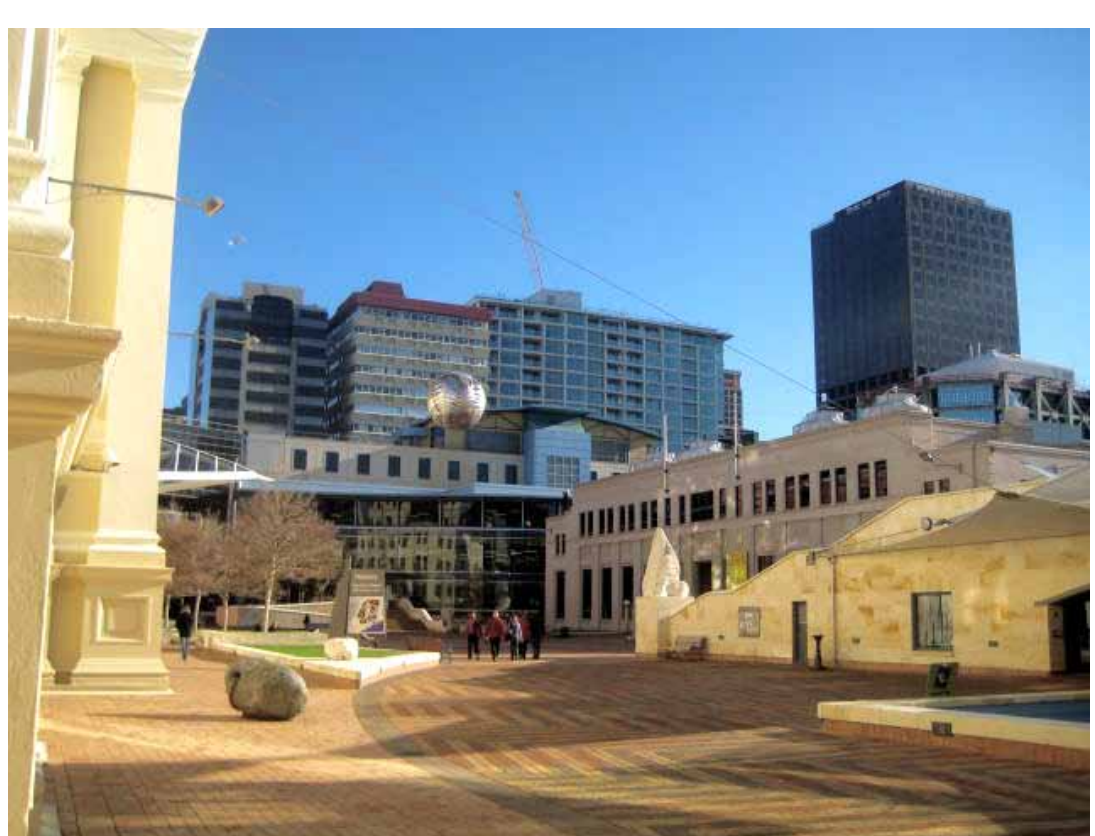

Fig 5.6 Civic Square

A colourful an popular open space. Wellington City Council's offices are here. Civic square and the City-to-sea bridge lie

adjacent to the waterfront and help to connect the central city with the sea. 
An urban assessment of the study area has been made in order to design an effective solution to the problem of sea level rise. The assessment considers two areas; the central city and the waterfront. Generally, the site has high-quality urban design with a high level of legislature and council commitment to quality improvement.

Wellington City is the capital of New Zealand, and is known as the country's 'arts capital' (Maclean, 2009). The city has a lively centre, with many cafes, restaurants, art galleries, museums and performance venues. The city's population accounts for $4.45 \%$ of New Zealand's population and is expected to steadily grow. In 2009 there were 195, 500 people living in the city (Wellington City Council, 2010).

\subsubsection{CENTRAL CITY}

Wellington's central city consists of compact assorted and colourful medium-scale, mixed-use buildings, wrapped around its waterfront. Growth is constrained by surrounding hills and the sea. Pedestrian and vehicular routes largely follow the north-south orientation (see fig...). The 'Golden Mile', 6 the name given to Wellington's main route, contains a major part of pedestrian and vehicular traffic including public transportation.

The report, City to Waterfront: public spaces and public life study: Wellington (2004), was commissioned by Wellington City Council, and directed by one of the world's topmost advisors on Urban Design, Jan Gehl. Gehl advised that movement in good public spaces should be primarily by walking and cycling, and that vehicular traffic should be limited (Gehl, 2004, p. 6). He concluded that Wellington City lacked street hierarchy, and needed a stronger emphasis on urban quality and improved conditions for walking, cycling and public transport (p. 11). Although he saw the Golden Mile and the waterfront promenade as significant (p. 14), he emphasised that pedestrian connections between city and water should be strengthened (p. 20).

The Gehl Report stated:

\section{Vehicular traffic is dominating Wellington City centre and has a negative effect on a}

number of streets and public spaces. City streets have been turned into highways and the vehicular traffic flows through the city centre are high, much higher than what would be expected of a city the size of Wellington.

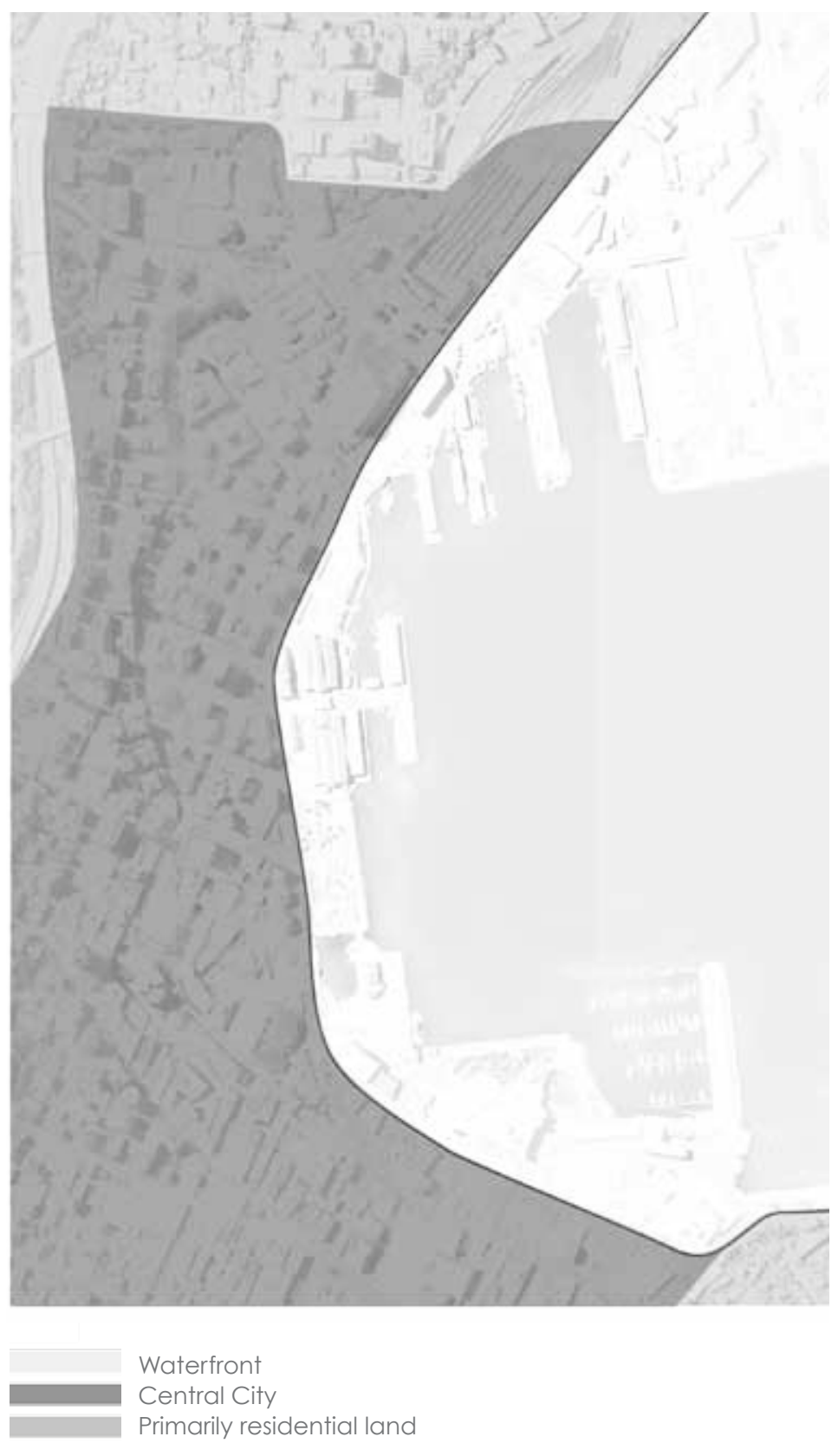

Map 5.7 Urban assesment areas: Central City and Waterfront Areas

6. The 'Golden Mile' is made up of 3 streets: Lambton quay, Willis St, Manners St, Manners Mall, and Courtenay Place. (Gehl, 2004 
City designers and planners have recognised the importance of connections to the waterfront and harbour (Te Whanganui a Tara). An almost 10km-long promenade extends along the waterfront from Point Halswell to the northernmost point of the city. A series of short scenic pedestrian routes run perpendicular to the waterfront, ensuring public access to the coast and a pleasant environment.

The waterfront provides Wellington City with wonderful outdoor opportunities (Gehl, 2004, p. 4). Recent upgrades of Waitangi Park (2009) and Kumutoto Precinct (2009) have contributed to its character and urban quality. Queens Wharf, as the 'heart of the waterfront' (Waterfront Leadership Group, 2001, p. 27), is T-shaped reflecting Wellington's mercantile history. Cruise ships and other vessels are encouraged to moor alongside it. The less developed North Queens Wharf retains sea views and has a strong maritime character. Public waterfront space north of the Kumutoto Precinct is generally of lower quality and less well used.

Despite constant and varied development, the waterfront has retained a distinct and unique character, with an historic maritime essence. Principally a public space, the 'well favoured relationship between city-and-sea plays a part in a sense of collective ownership, and sense-ofplace for Wellington's residents' (Wellington City Council, 2004).

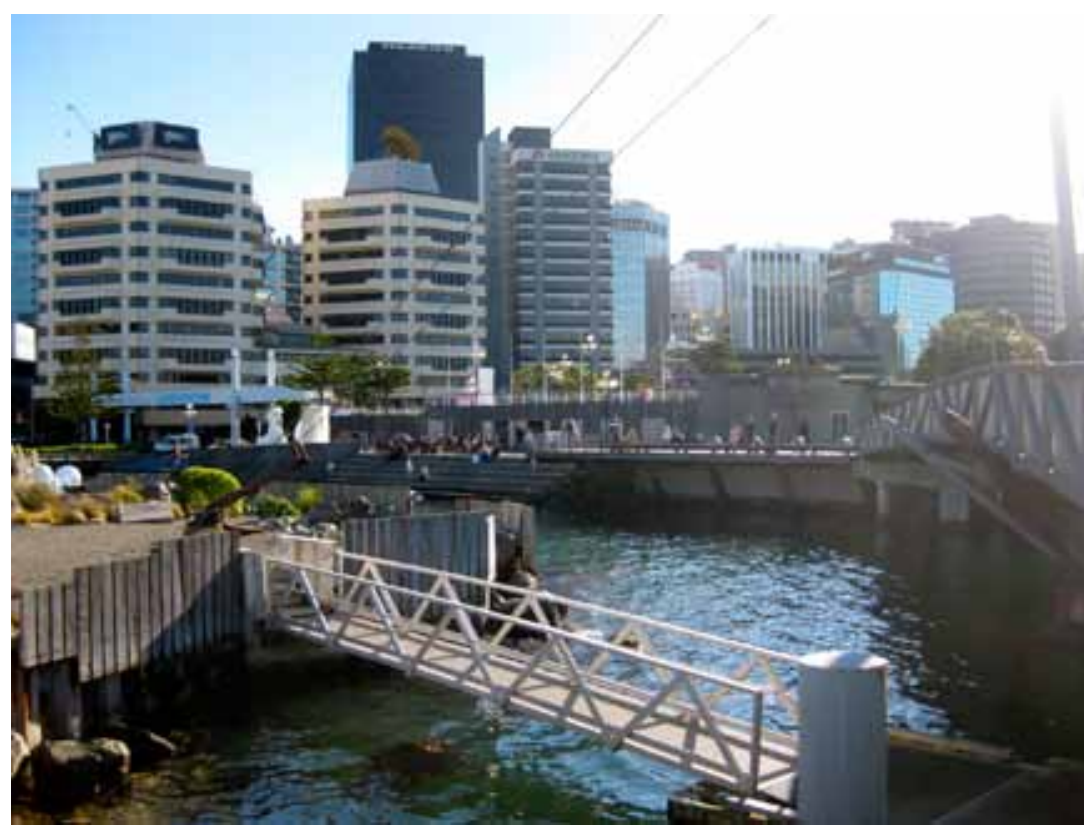

Fig 5.8 Lagoon area, Wellington waterfront

The lagoon area is a popular public area that contributes storngly to Wellington's sense-of-place. The lagoon provides users with a large number of opportunities for a range of activities including swimming kayaking, running, sitting and eating. 


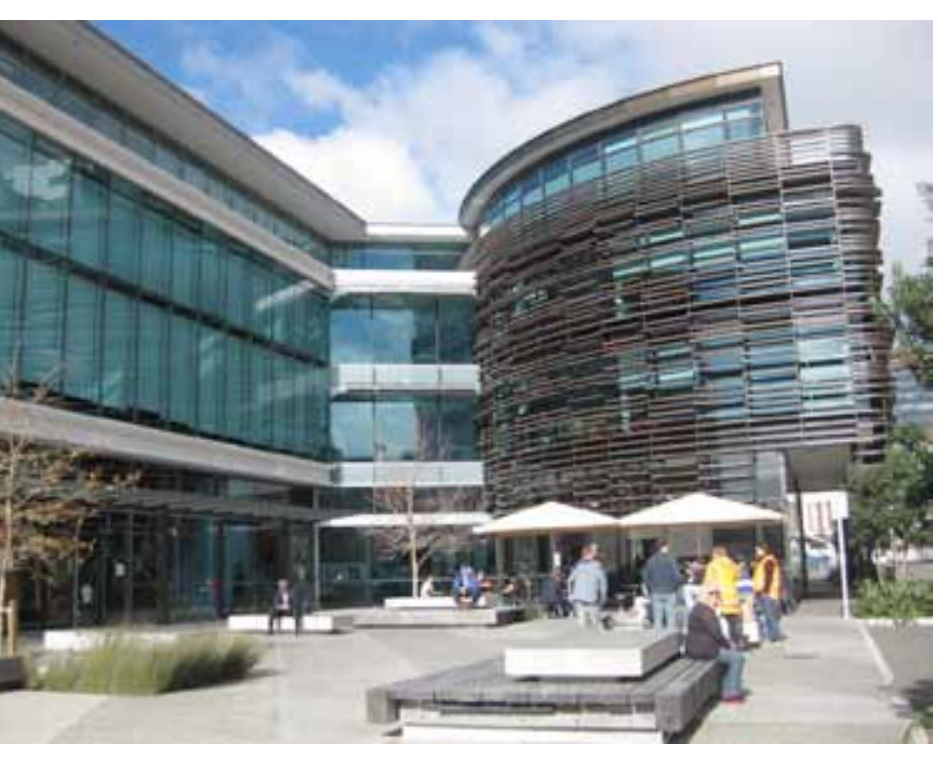

Kumutoto Precinc Public seating by the new Meridian Energy building

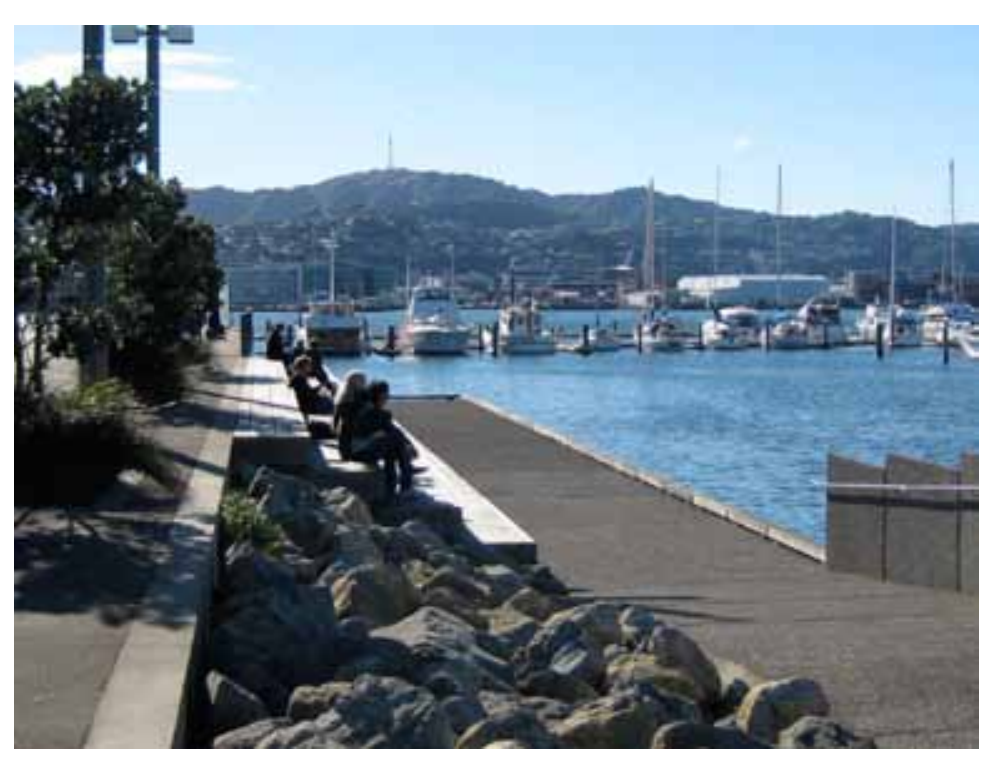

Seating along waterfront promenade

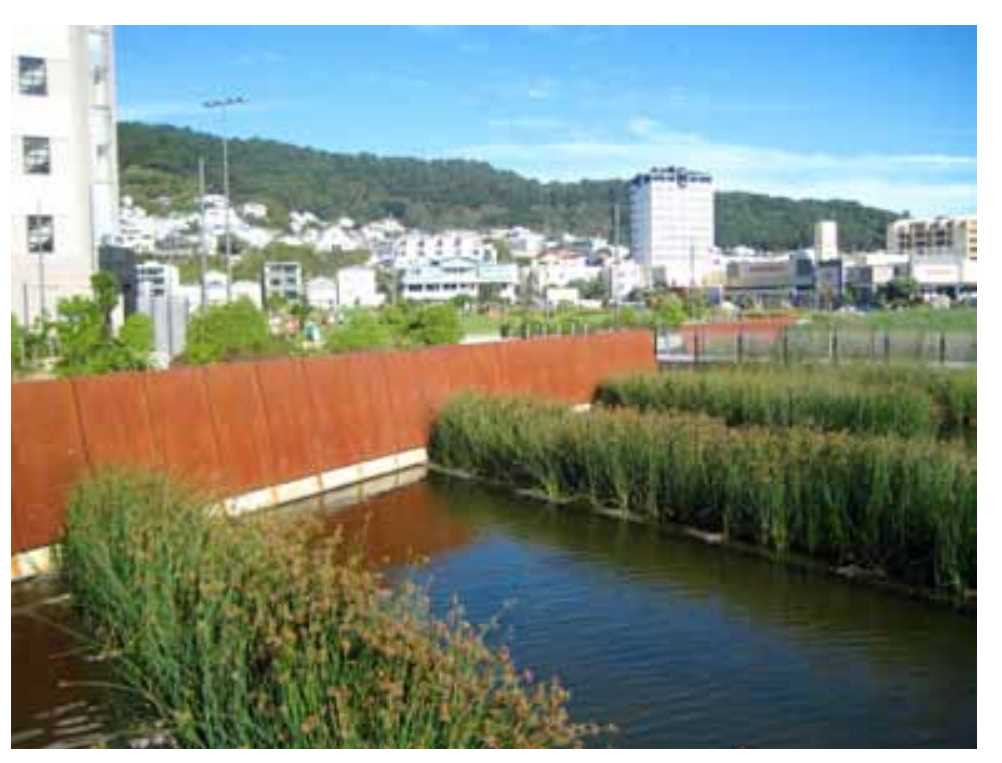

Waitangi Park Constructed Wetlands are treat the Waitangi Stream before it is released into the harbour 


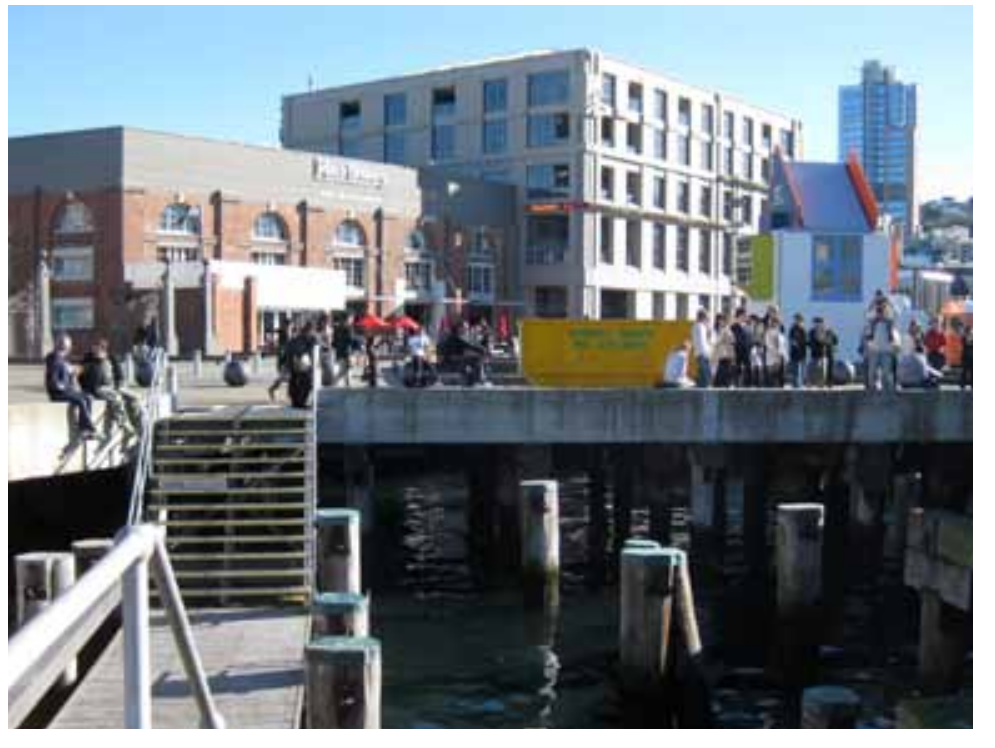

Wharf by Te Papa exposing piles and sea beneath

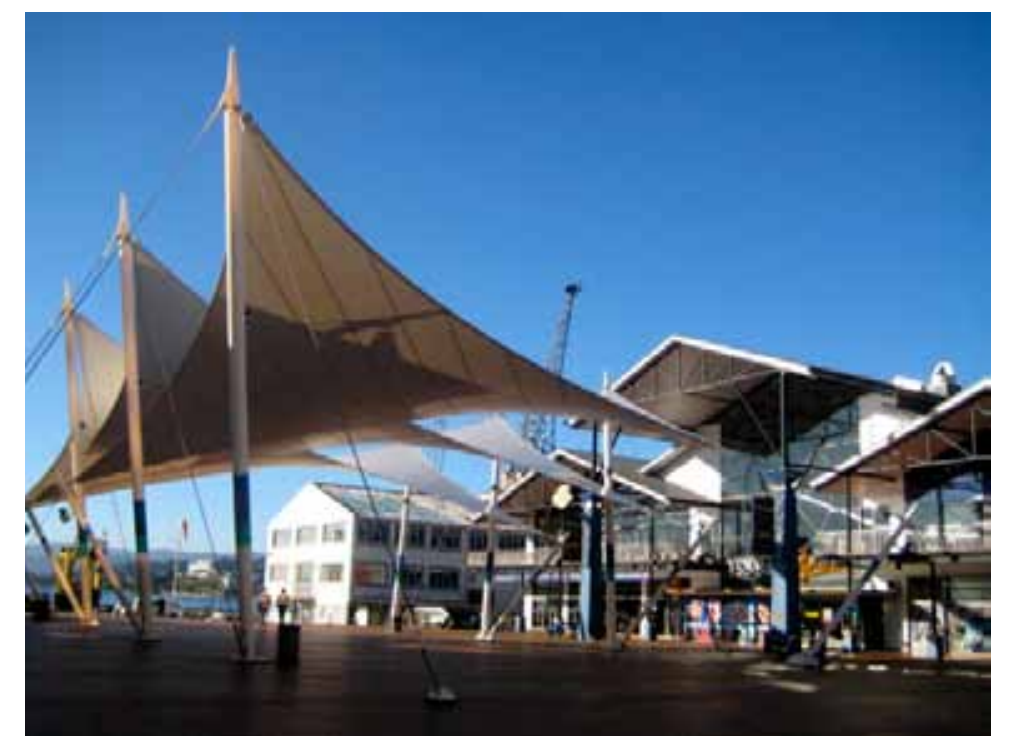

Queens Wharf An event stage and public space: Contains a museum, restaurants, sports equipment hire, and office

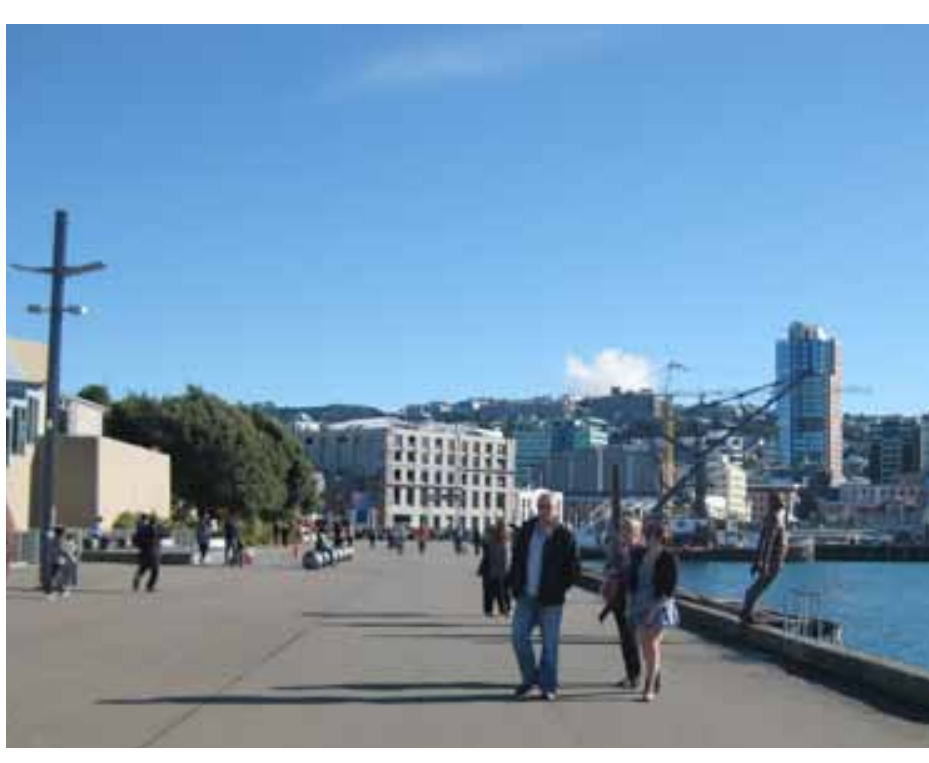

Waterfront Promenade Te Papa to the left of image Sculpture Solice in the Wind by Max Patte on the right 
These two maps display flooding hazards when shown from a wider context. Topography information is displayed through the underlying grey maps. This project study site is indicated on the maps by the dotted black lines.

The left map shows flood hazard zones (fig 5.9). The dataset for flood hazards was obtained from Wellington City Council. It is derived from a combination of historical data and information created from catchments modelled under the Council's catchment management plan. ${ }^{7}$ This map identifies the potential areas where flooding could occur due to unusual high tide and high wind or during high and long periods of precipitation. The adjacent map shows an area of land under inundation threat due to Tsunami risk (fig 5.10). This data was created by Wellington Regional Council. The study site has a high risk of flooding in extreme events, even without significant rise in sea level.

\subsection{DISCUSSION}

Wellington City planners place emphasis on good urban design, but have not yet comprehensively considered the prospect of sea level rise. While most Wellington residents are happy with their city (Wellington City Council, 2010, p. 110), there are still urban design challenges to be faced. Public space is generally of good quality, but much is at risk of damage from sea level rise.

Those who could be affected by sea level rise must be informed of the risks and consequences of a range of scenarios. Both Central and Local Government need to start discussions about effective risk management and implementation with a range of stakeholders, such as scientists, administrators, business owners, landowners and community organisations.

A comprehensive response to sea level rise offers an opportunity to improve the city's urban fabric, rather than just take remedial action. 


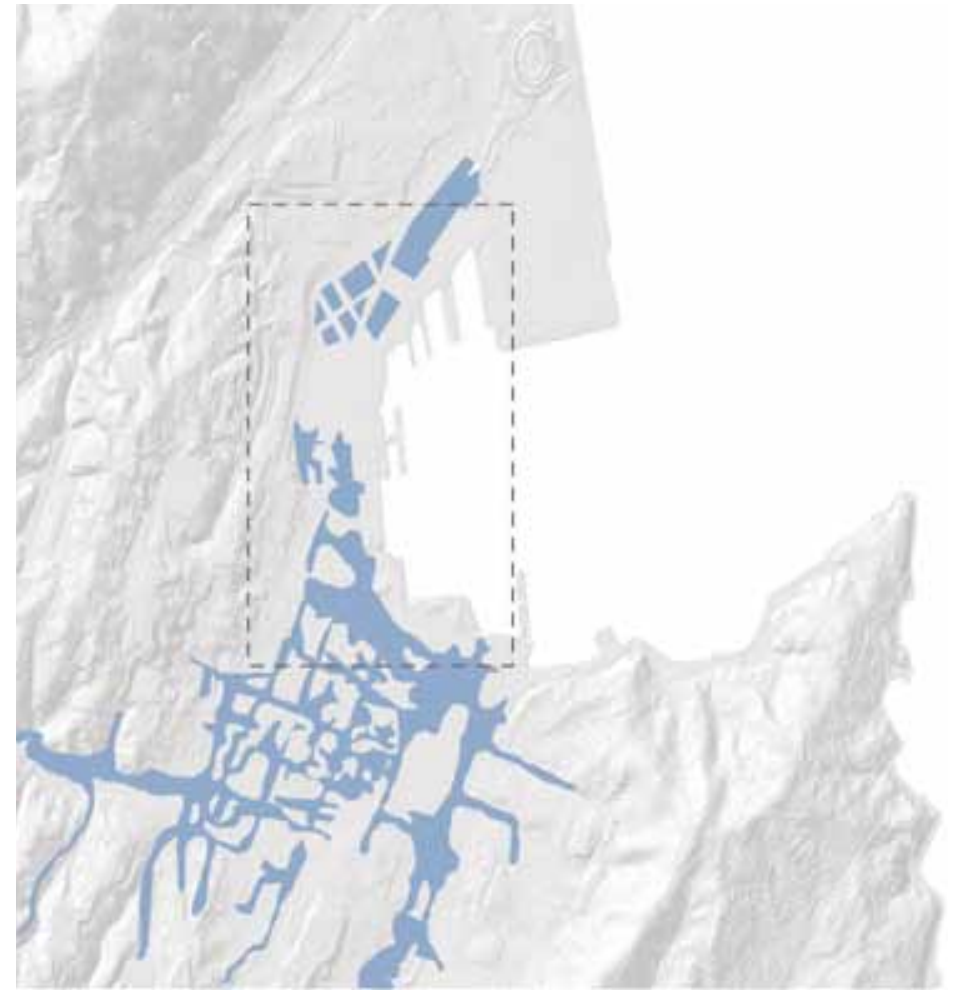

Fig 5.10

Area under threat due to flood hazards

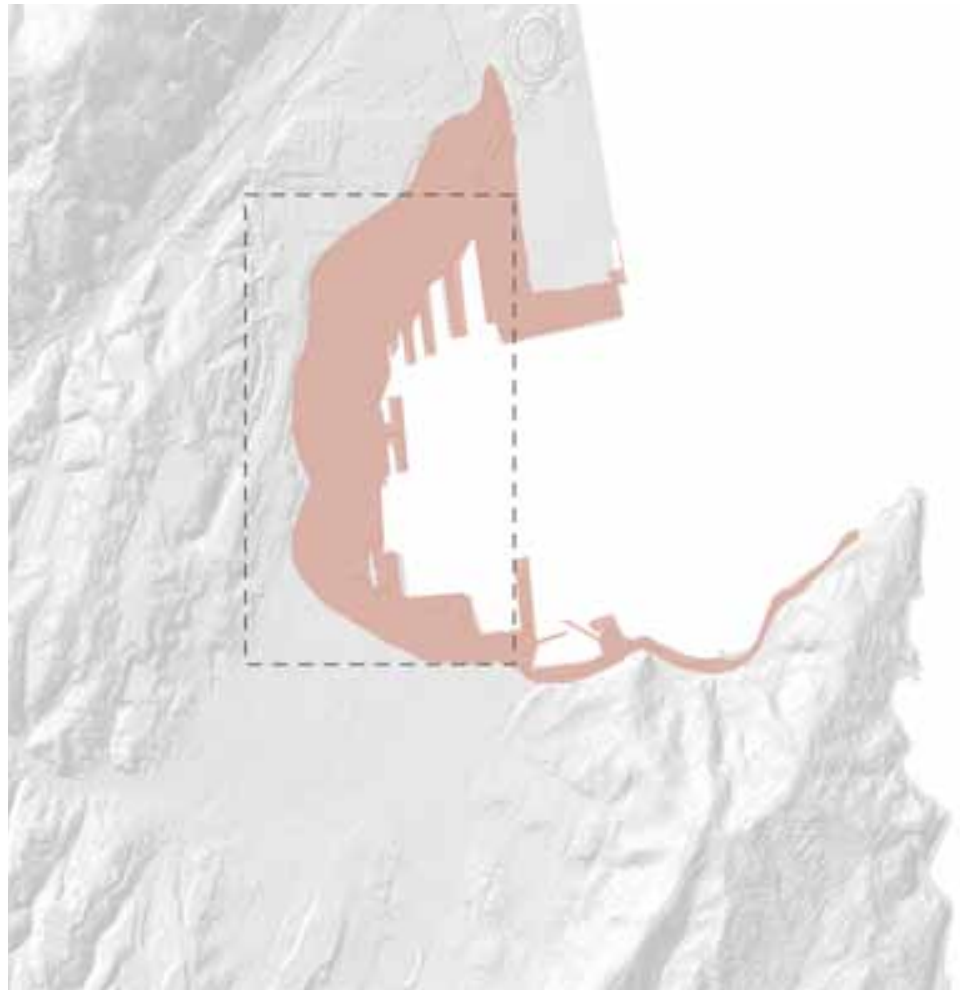

Fig 5.11

Area under threat due to tsunami risk

$$
\begin{array}{cr}
0 & 500 \quad 1000 \\
\hline & \text { metres }
\end{array}
$$




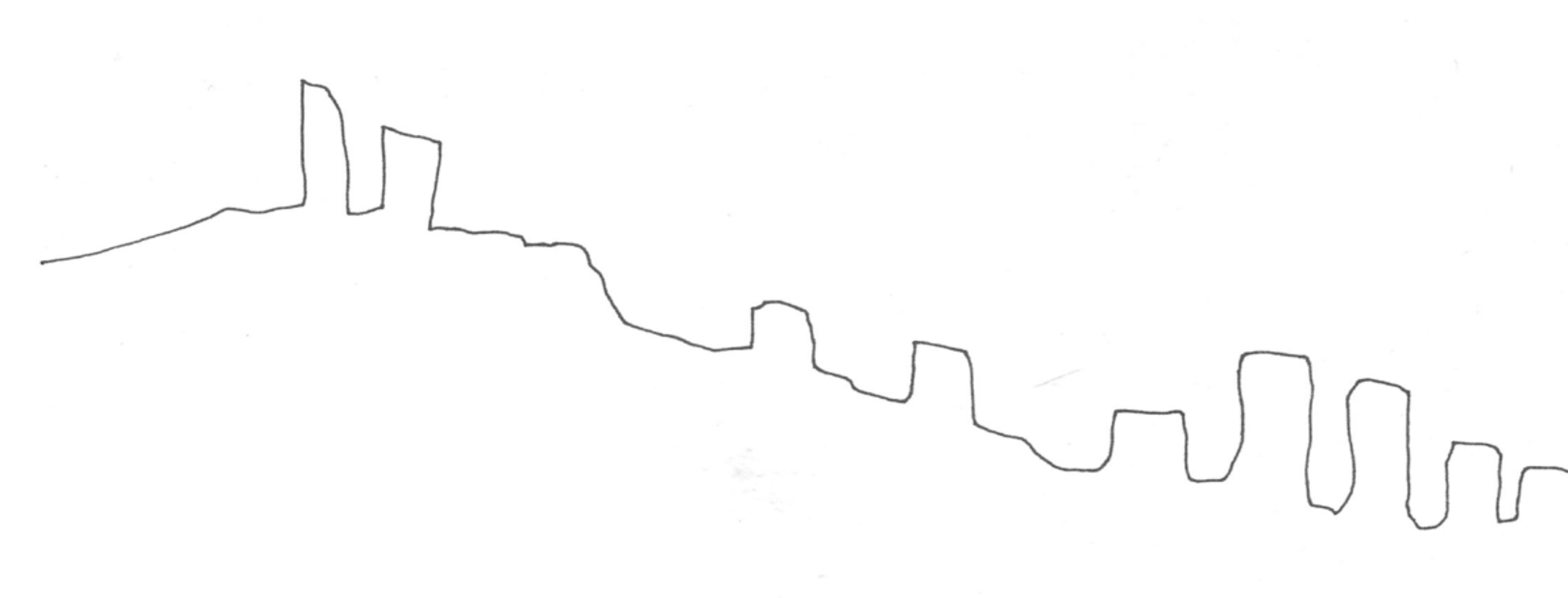




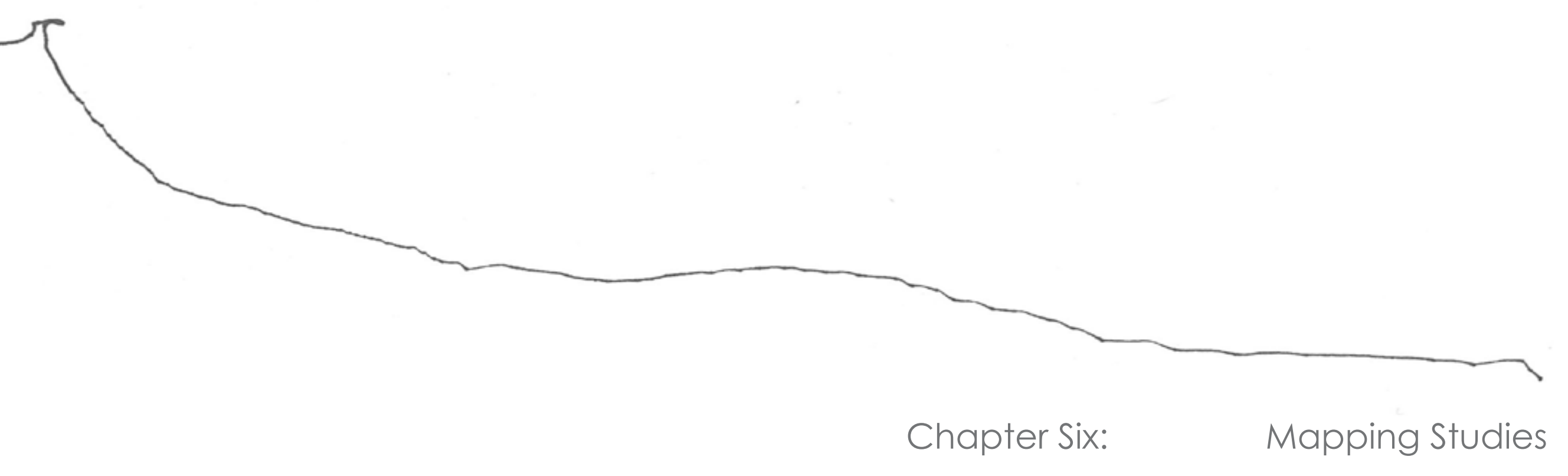


An accurate and thorough scenario-based case study of Wellington City is needed to fully understand the effects of sea level rise.

Given considerable uncertainty in projections (Ramsay D. a., 2008) and the possibility of catastrophic events, three core scenarios are examined: the sea level rises of $0.5 \mathrm{~m}, 1 \mathrm{~m}$ and $1.5 \mathrm{~m}$. An understanding of all scenarios is also useful, as the $0.5 \mathrm{~m}$ and $1.5 \mathrm{~m}$ maps show the effects of a typical daily low tide and high sea surge are comparable to a low tide and high sea surge of the one metre scenario.

The next chapter focuses on designs for the one metre sea level rise scenario. This scenario has been chosen because it is the middle-to-high range of many estimates for the year 2100. A onemetre rise is realistic, and will have significant impact on a substantial section of the city. Analysis has involved a number of mapping studies. The original one metre scenario map is overlaid by urban design analyses including figure ground plans, circulation routes (pedestrian and automobile), figure ground mapping, public space and flooding hazards. These analyses are important to comprehend how sea level rise could affect the urban design framework of the city.

Mapping for the following sea level rise scenarios was done specifically for this study by the GIS team at Wellington City Council. The three scenarios display an even range of possibilities for sea level rise, as they reflect the most recent scientific probabilities for the year 2100. The scenarios chosen are similar to a recent sea level rise analysis of the Kilburnie Town Centre' made by the council. Geographic information systems (GIS) were used by the Council to map the scenarios for Wellington City based on ground elevation data from LiDAR (Light Detection and Ranging). LiDAR data was captured at $1 \mathrm{~cm}$ vertical intervals with $+1-10 \mathrm{~cm}$ height accuracy. ${ }^{2}$ Maps have been created noting an additional $0.5 \mathrm{~m}$ storm surge component within the harbour and a $1 \mathrm{~m}$ component on the exposed southern coast.
These numbers have previously been used in a recent GIS analysis of Kilbirnie town centre Kos, P. (2009). Assessing the Implications of Sea Level Rise on Kilbirie Town Centre. Wellington City Council, City Planning Team. Wellington: Wellington City Council.

LiDAR information is used to accurately depict terrain. Several comparable Sea Level Rise modeling studies around the world have employed LiDAR models and GIS to map anticipated Sea Level Rise scenarios. LiDAR data uses a local vertical datum as base (Wellington Vertical Datum 1953/WVD53)

For this study LiDAR mean sea level (MSL) is $0.165 \mathrm{~m}$ above WVD53 and mean high water springs (MHWS) are $0.855 \mathrm{~m}$ above WVD53 (0.69m above MSL). SLR scenarios used MHWS as a base to which scenario heights were added. This allowed for assessment of the highest sea level accounting for mean tidal elements.

A terrain model was created once accuracy of LiDAR data was deemed acceptable No official breakwater data was deemed acceptable. No of ficial breakwater heights were available for analyses so were estimated by adding/deducting a height offset between the breakwater and nearest LiDAR height value and incorporated into the
terrain model. 


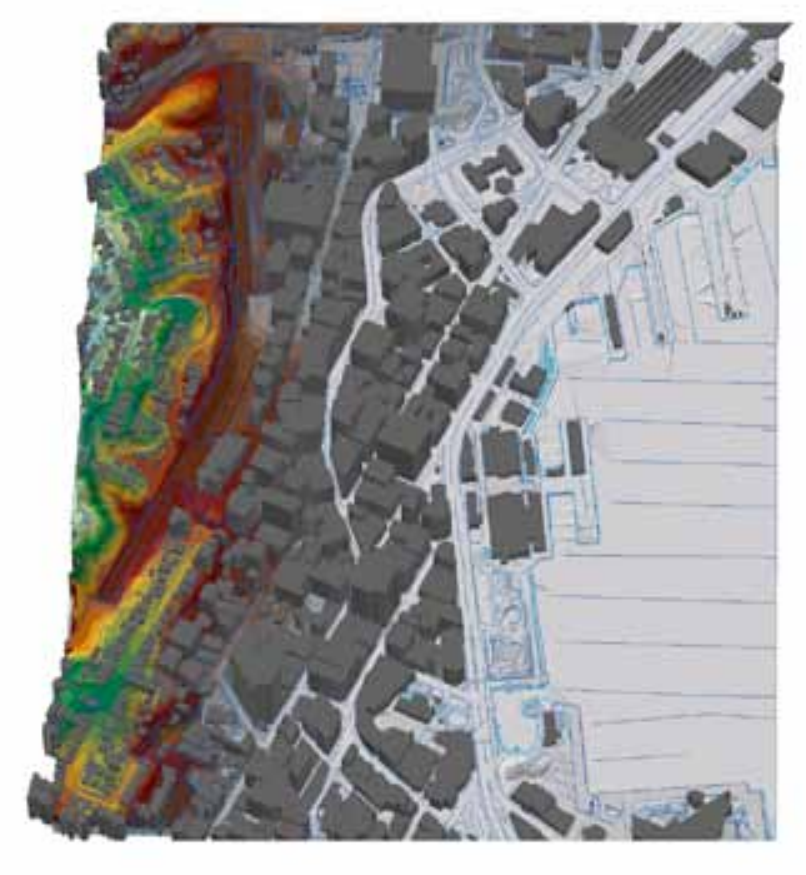

$0.5 \mathrm{~m}$ sea level rise scenario

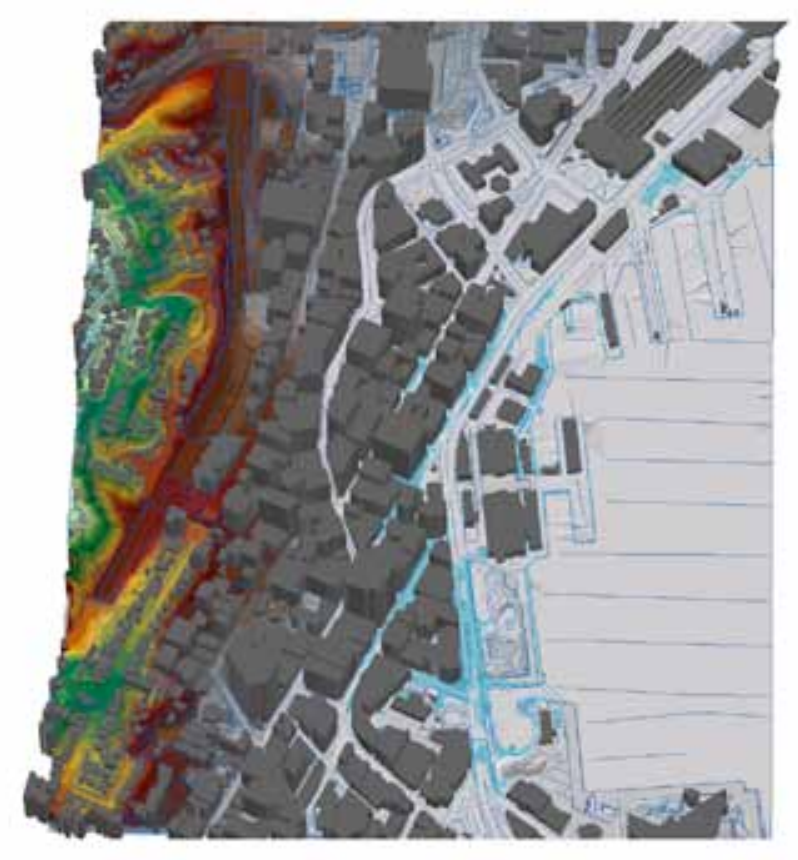

$1.0 \mathrm{~m}$ sea level rise scenario

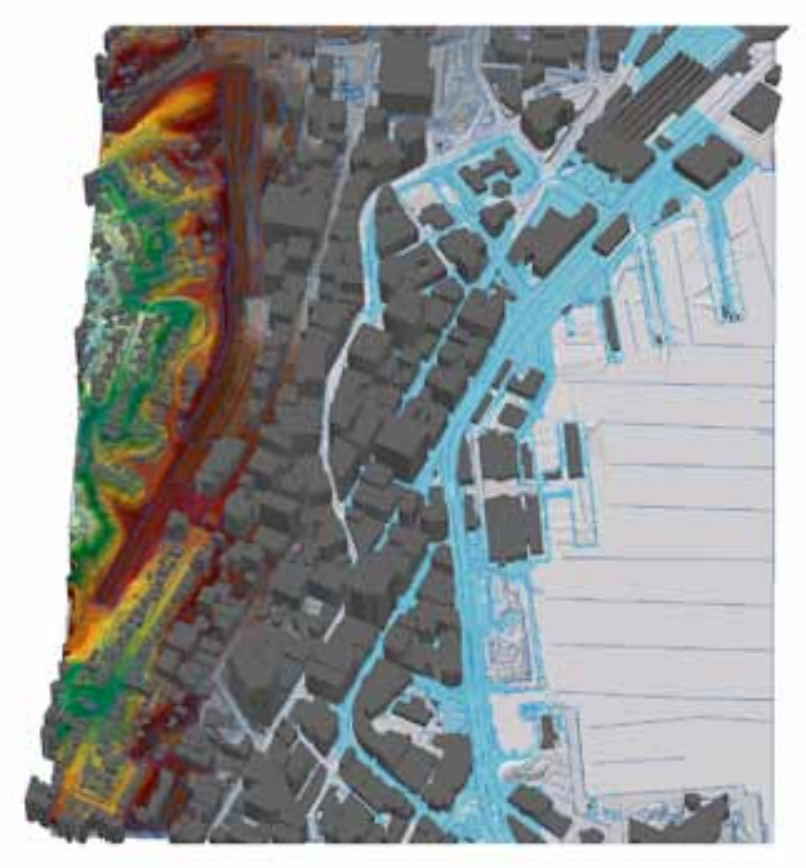

$1.5 \mathrm{~m}$ sea level rise scenario 
A mean sea level rise of $0.5 \mathrm{~m}$ is highly likely within the next 100 years.

A mean sea level rise of $0.5 \mathrm{~m}$ will have minimal effect on the Wellington's central city. The piers surrounding the central city are high enough to protect it. However, damage might be caused by increase in sea surge levels and wave height.

This discovery is significant because it shows Wellington has more time to react than many other coastal cities. By the time global sea levels have risen by $0.5 \mathrm{~m}$, solutions found for other coastal cities should provide a wider range of response options before conditions become intolerable in Wellington.

There is a probability of:

- Increased saltwater intrusion into drainage pipes and vegetation areas.

- Flooding in roadways during storms.

- $\quad$ Small pockets of water along the waterfront due to rising water table.

With careful long-term planning, Wellington City will cope with sea level rise of $0.5 \mathrm{~m}$ without needing to drastically transform its infrastructure. 
A mean sea level rise of $1.0 \mathrm{~m}$ is likely within the next 100 years.

A $1.0 \mathrm{~m}$ rise will cause considerable damage to Wellington's central city. Without changes to stormwater systems, there will be significant flooding and inundation. Existing edifices, transportation routes and lifeline infrastructure such as electricity, telecommunications and emergency systems will be in danger of serious damage.

Specific major effects include:

- Inundation of railway lines near the Central Railway Station.

- Serious inundation of major vehicular routes Jervois Quay and Customhouse Quay. Partial inundation of Waterloo Quay, Featherston Street and Customhouse Quay.

- Total inundation of Manning Lane, Harris Street, Willeston Street, Hunter Street. Partial inundation of Victoria Street, Grey Street, Panama Street, Brandon Street, Johnston Street, Waring Taylor Street, Maginity Street and Featherston Street.

- $\quad$ Partial inundation of new Bank of New Zealand (BNZ) building, Meridian Energy building (along the waterfront), Wellington Central Police Headquarters (Victoria Street) and many other waterfront buildings.

- Threat of inundation of many basements, such as the Wellington Central Police Headquarters, Town Hall, City Art Gallery, Central Library and Old Bank Arcade.

- Loss of direct access to waterfront activities: boat terminals, container storage, waterfront traffic routes, recreation facilities, helicopter pad and event stages. 


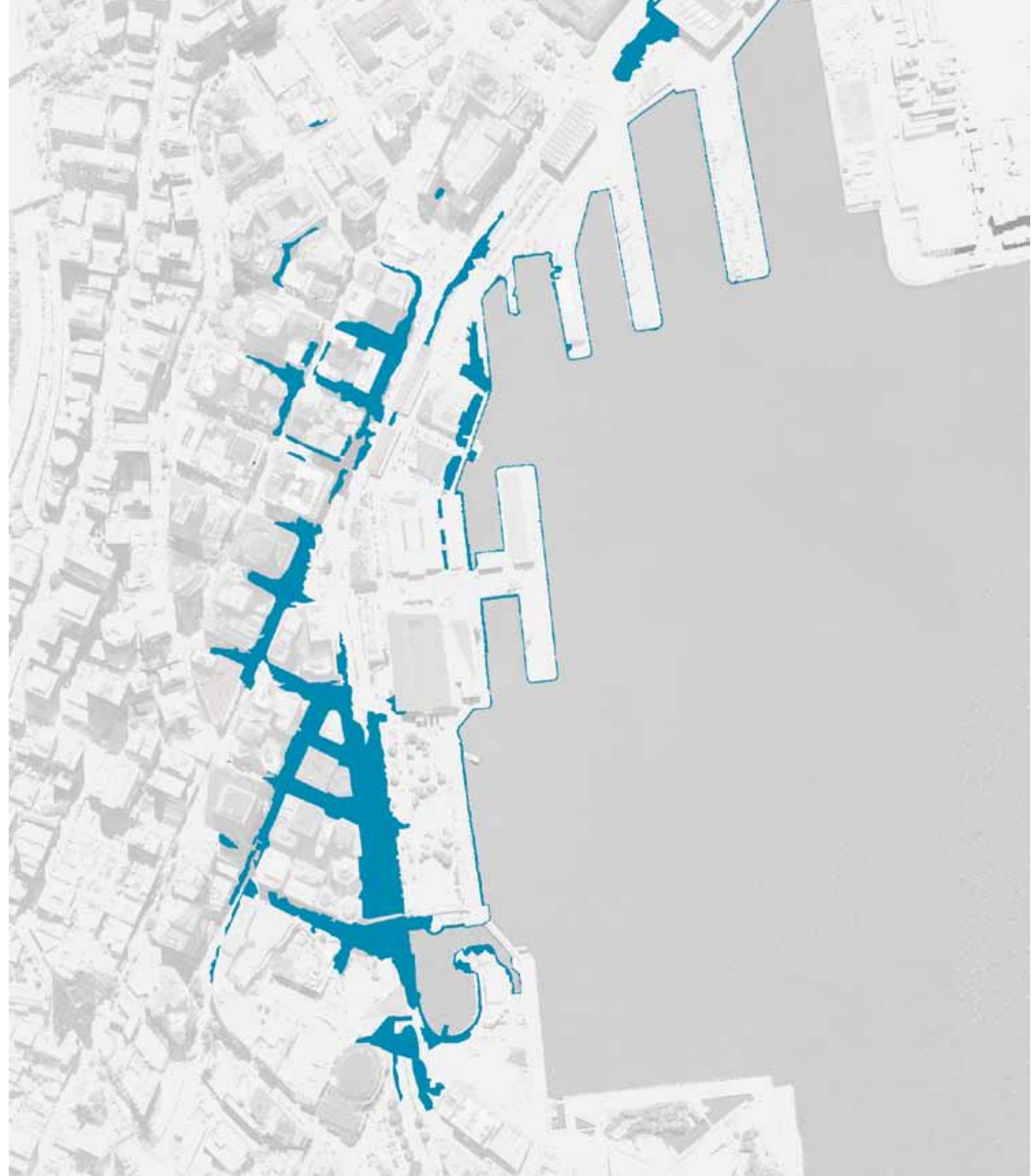


A mean sea level rise of $1.5 \mathrm{~m}$ is less likely to occur within the next 100 years.

A sea level rise of $1.5 \mathrm{~m}$ will require major changes to the central city; some of these will likely have been implemented as a response to lesser rises.

Additional effects include:

- $\quad$ Serious inundation of the majority of reclaimed porous land beneath high-rise buildings within financial and retail centres.

- Creation of small islands along pier sites and within the central city: Queen's Wharf, Frank Kitt's Park, Civic Square, Victoria University's Pipitea campus.

- Total inundation of major vehicular and pedestrian traffic routes.

- Widespread inundation of basements. 
Further mapping of the one metre sea level rise scenario involves overlapping of important urban design elements and relationships. These maps have been superimposed over the $1 \mathrm{~m}$ sea level rise scenario prediction in order to further understand the effects of the potential rise.

One metre contours are shown in the first map (fig 6.5). Land contour data is necessary to know in order to make the best possible predictions of water level during extreme storm events. The contour information was sourced from the Gis team at Wellington City Council.

Flooding hazard areas have been superimposed with the two higher sea level rise predictions (fig 6.6). The 1.5m scenario was combined with flood hazard maps in order to view potential flooding hazards from rainwater, stormwater, and seawater in a worst-case storm. The greatest potential damage is seen where all datasets overlay if no defences are in place. Civic Square block and a series of blocks contained between Jervois Quay and Victoria Street are of particular concern. Streets at most risk of flooding are Jervois Quay, Victoria Street and Customhouse Quay.

Circulation routes were superimposed over the sea level rise map to inform how sea level rise would affect current roads and circulation patterns (figures 6.7 \& 6.8). This mapping is significant as it clearly depicts the dramatic effects of sea level rise on movement within the city. A rise in sea level of 1 metre was found to result in flooding of many significant automobile roads, including total inundation of the major waterfront highway, Jervois Quay. Connection roads between Jervois Quay and the central city would also be flooded, causing vital city-to-sea connections to be lost. Flooding was found to inhibit the continuity of the pedestrian promenade along the waterfront, and a number of key roads that link the promenade to the central city.

Figure ground mapping of the city allows for the identification of buildings affected by the tides. In the buildings affected map (fig 6.9), buildings have been highlighted that, unless there are adequate defences, will be touched by daily tides. The second map (fig 6.10) highlights the affected heritage areas, sourced from Wellington City Council District Plan maps. Figure ground mapping clarifies the classification of affected buildings. The map only shows ground surface water; seawater will also seep into a large number of unidentified basements that lie beneath the high-tide sea level. Even though a sea wall exists, the majority of buildings within reclaimed land will be affected due to the land's highly porous nature. A further assessment of potential damage in terms of land ownership is displayed in figure 6.13, where Parcel boundaries are revealed. 


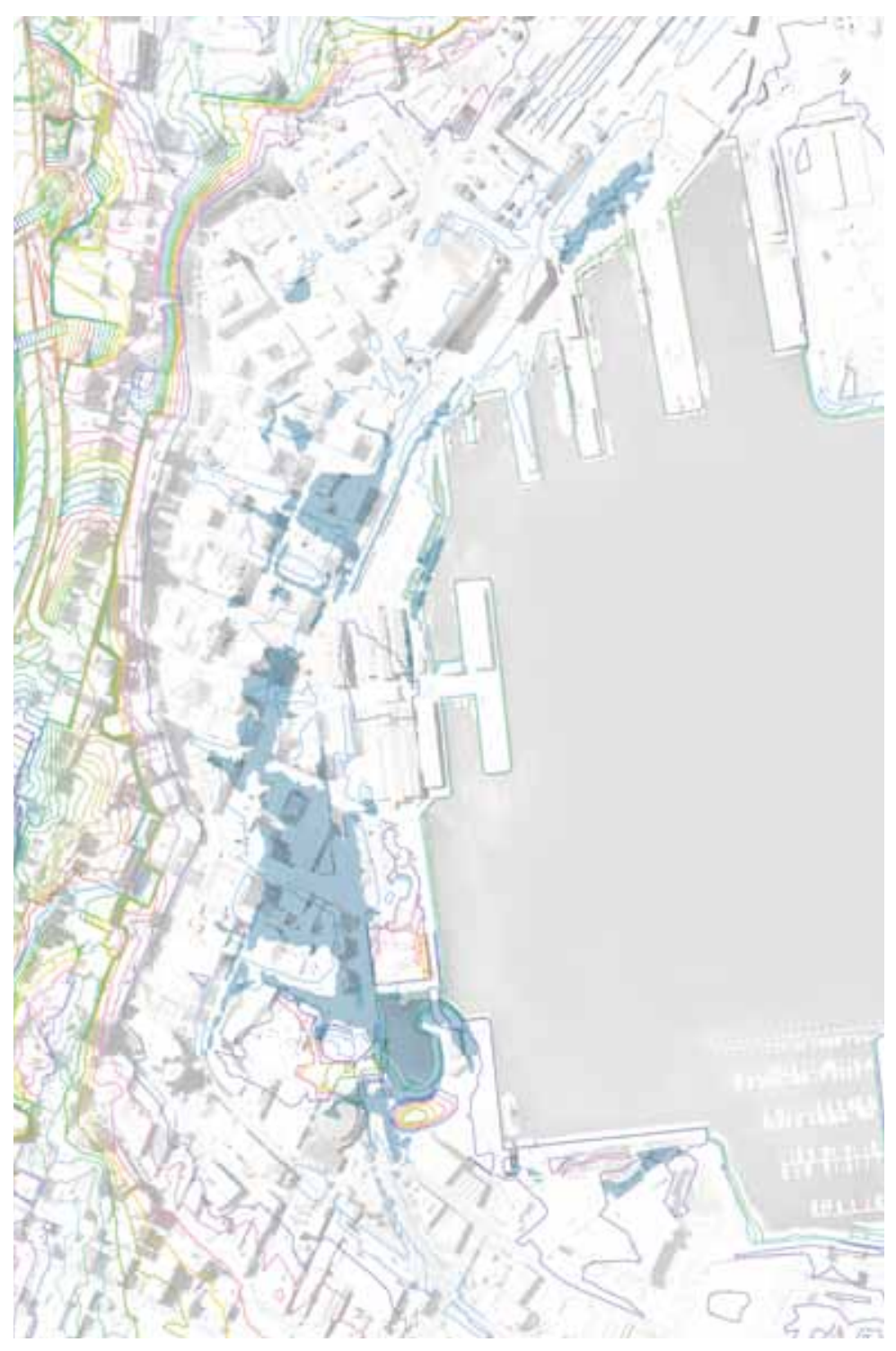

Fig 6.5 One-metre contours

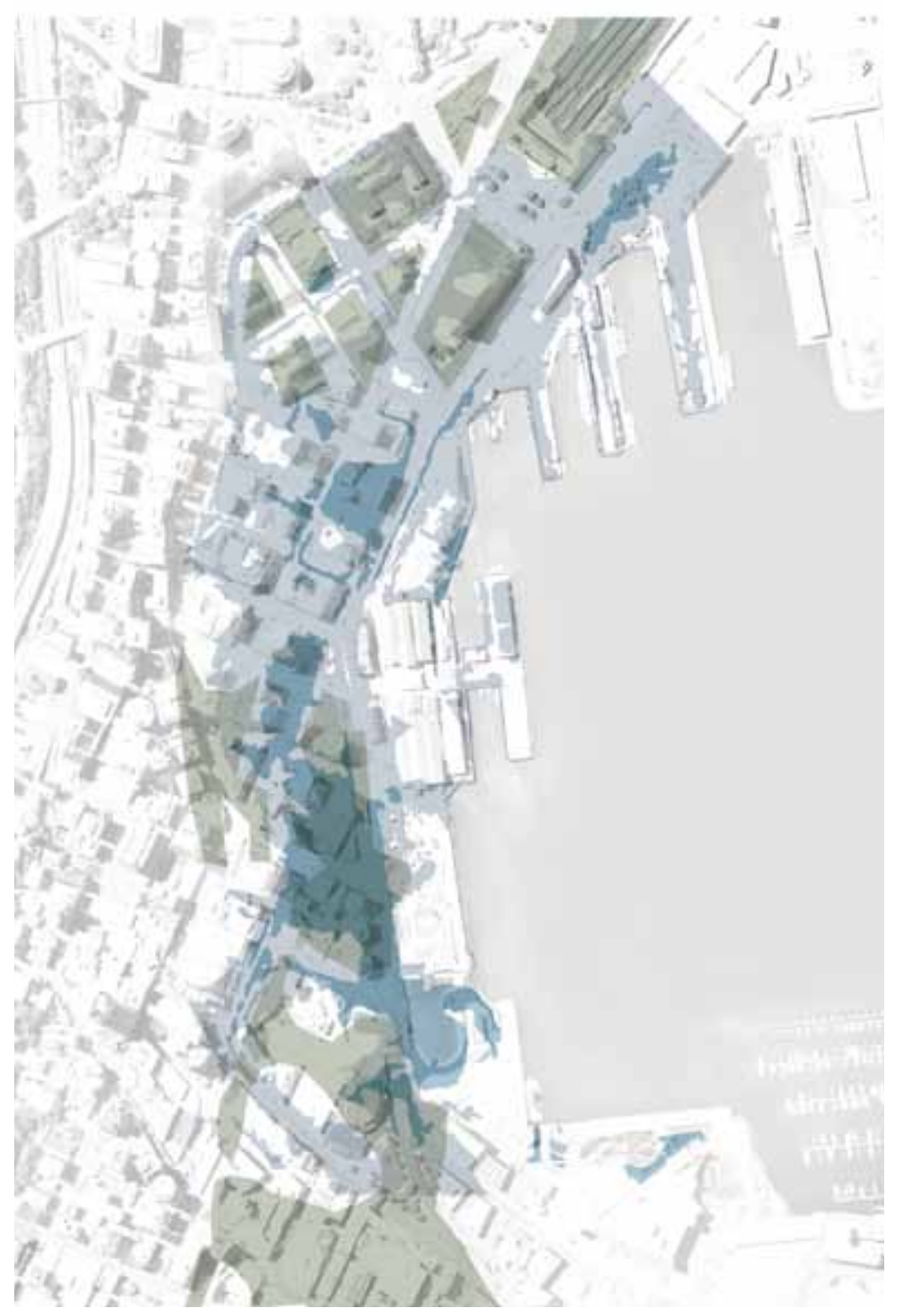

Fig 6.6

\section{Flooding hazards}

Flooding hazard area
Sea level rise scenario $1.5 \mathrm{~m}$
65 


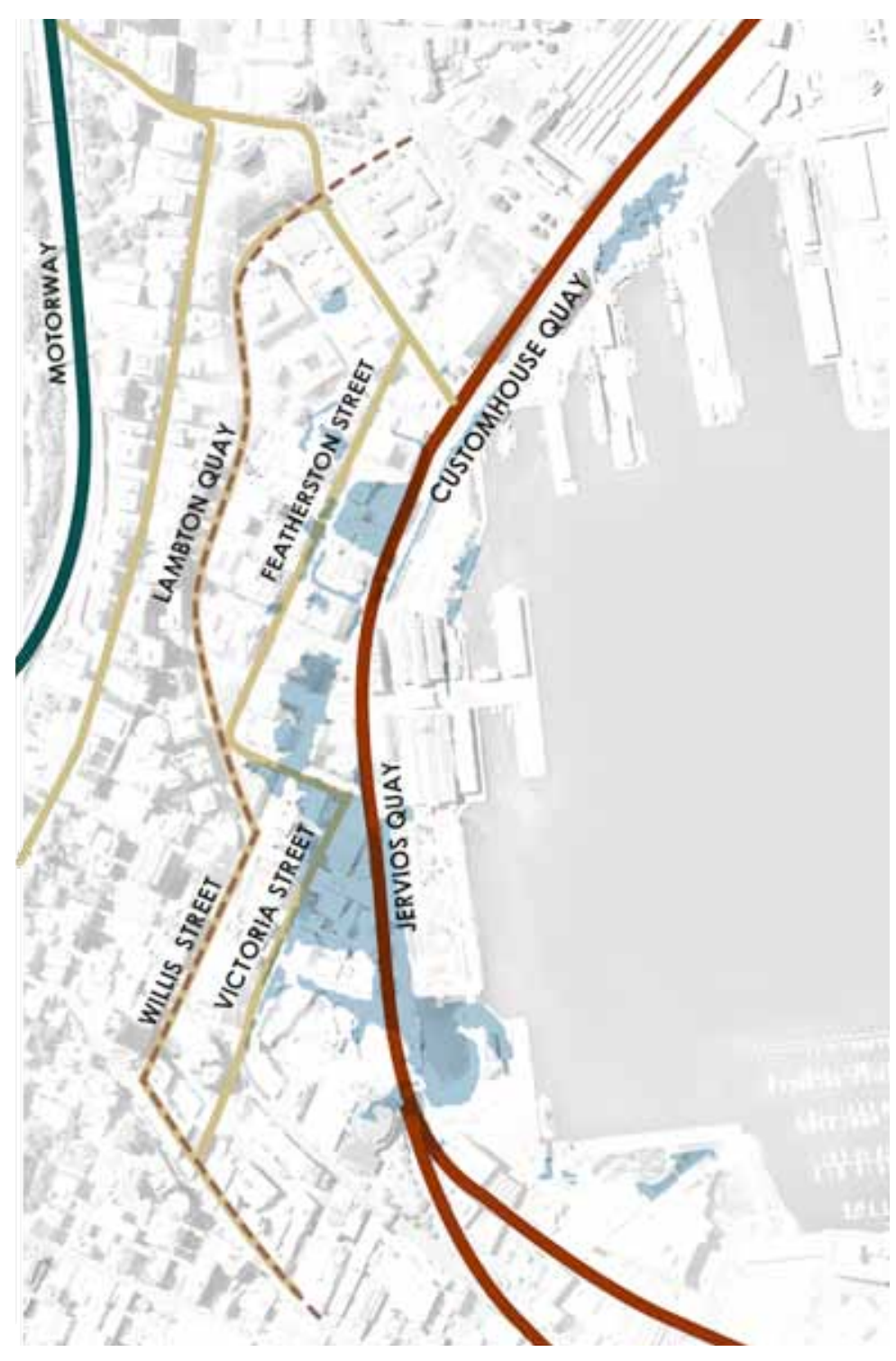

Fig 6.7

Main vehicular routes

Harbour-front route

Secondary route

..... Main bus route + Golden Mile

Motorway

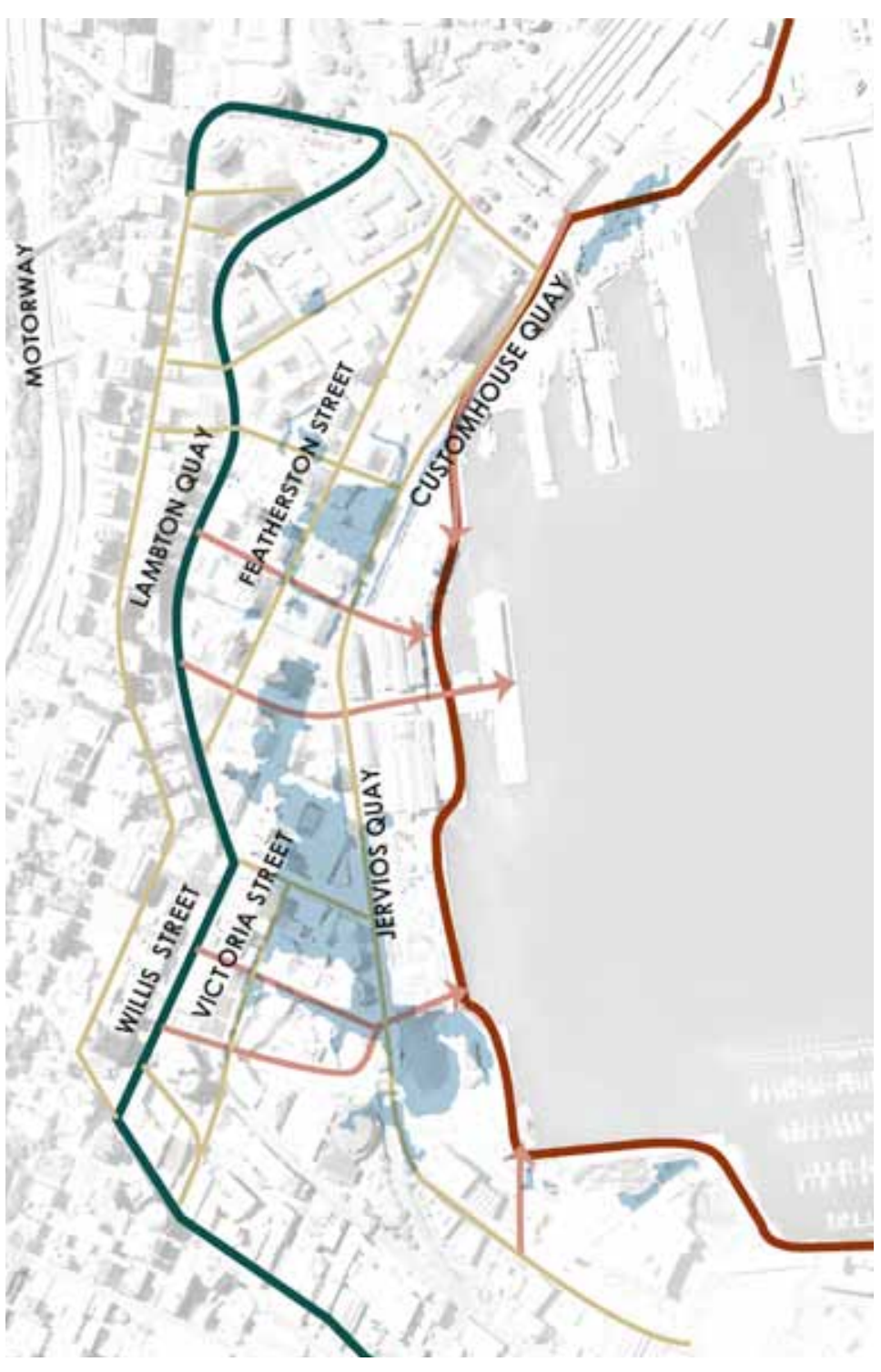

Fig 6.8

\section{Main pedestrian routes}

— Waterfront promenade

Main connection road cty-to-sea

secondary walking route

$0 \quad 400$ metres 


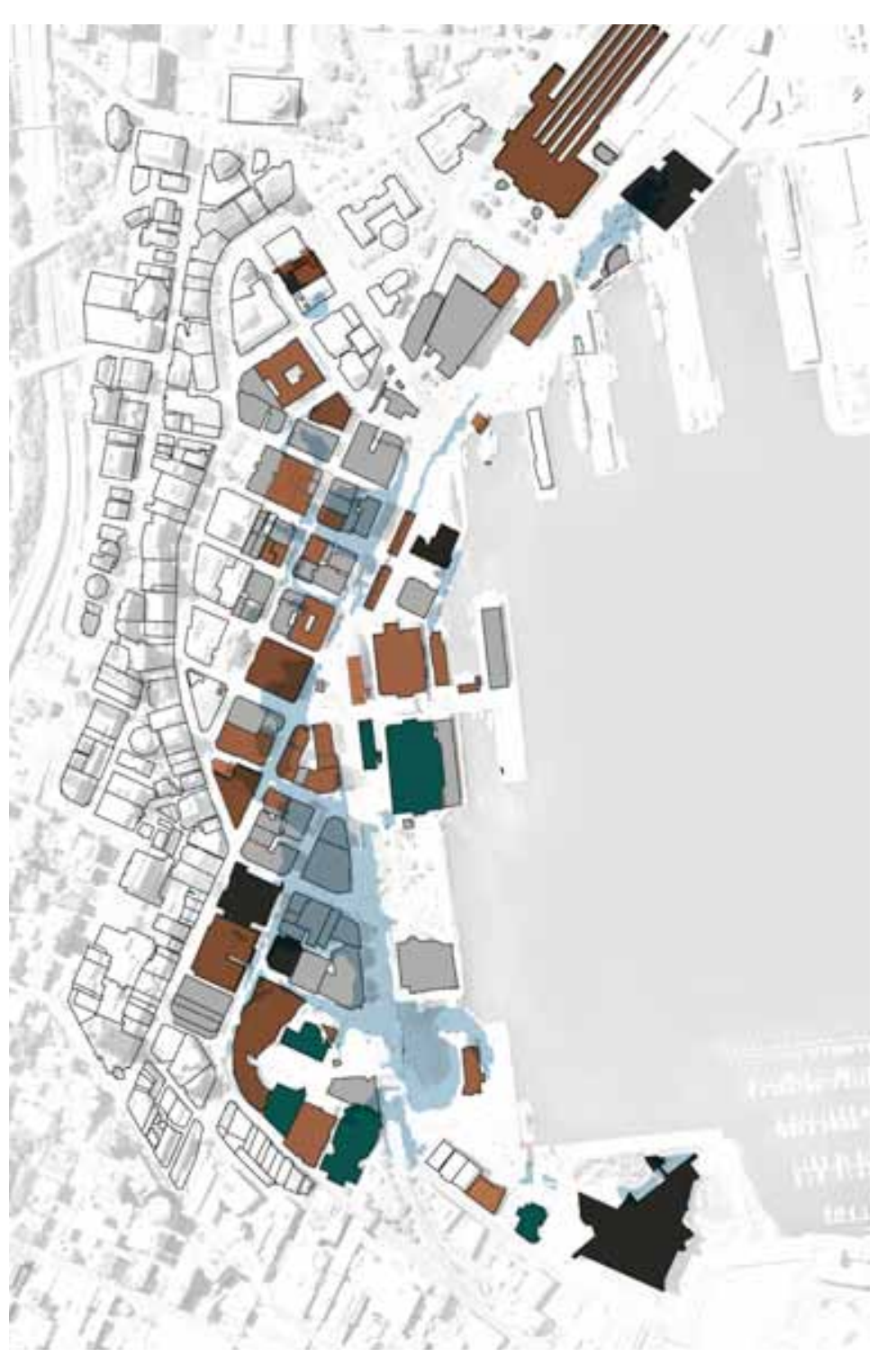

Fig 6.9 Buildings affected

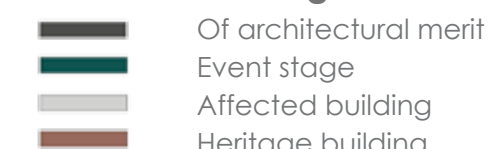

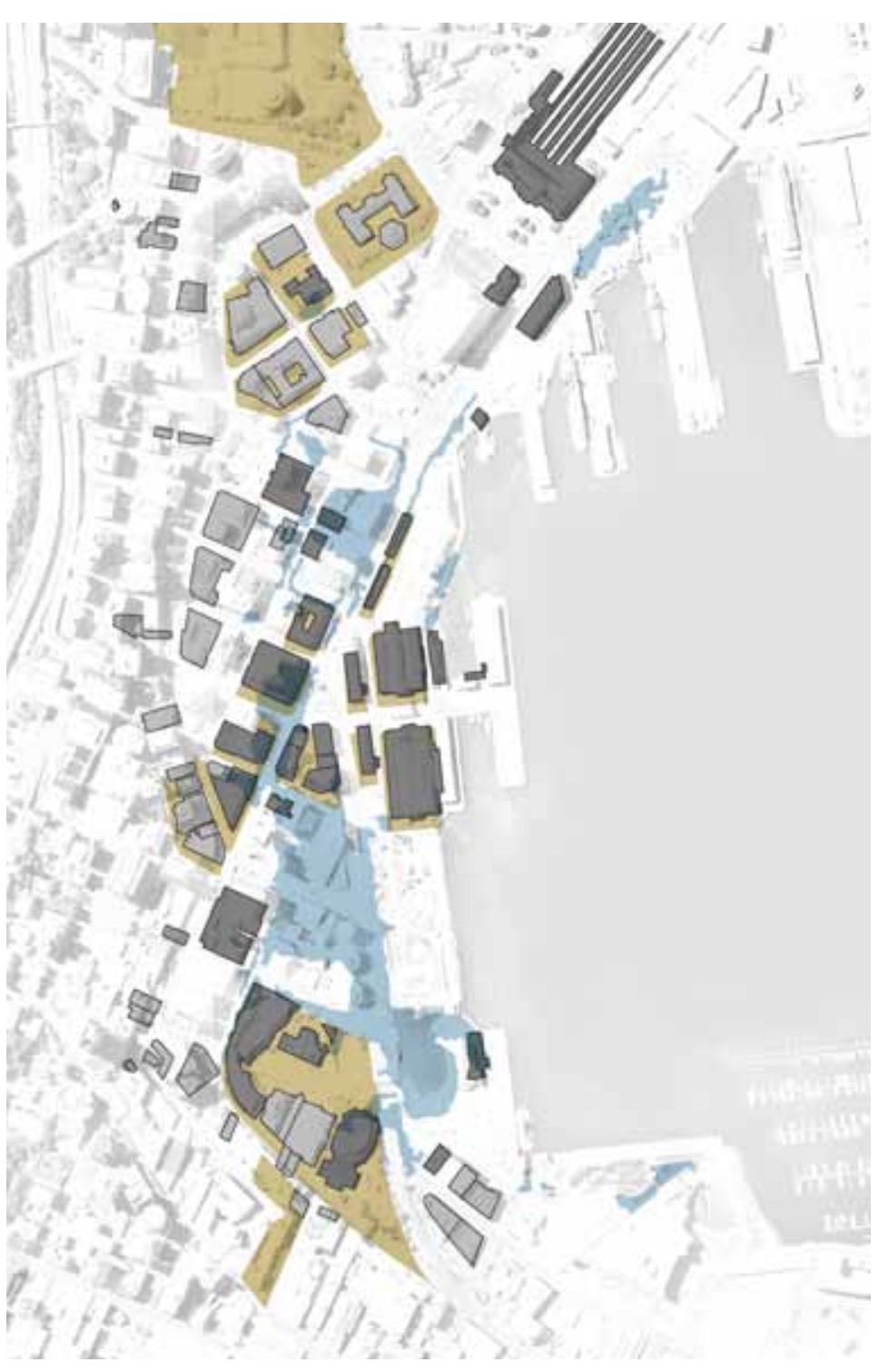

Fig 6.10 Heritage buildings and areas

Heritage area 


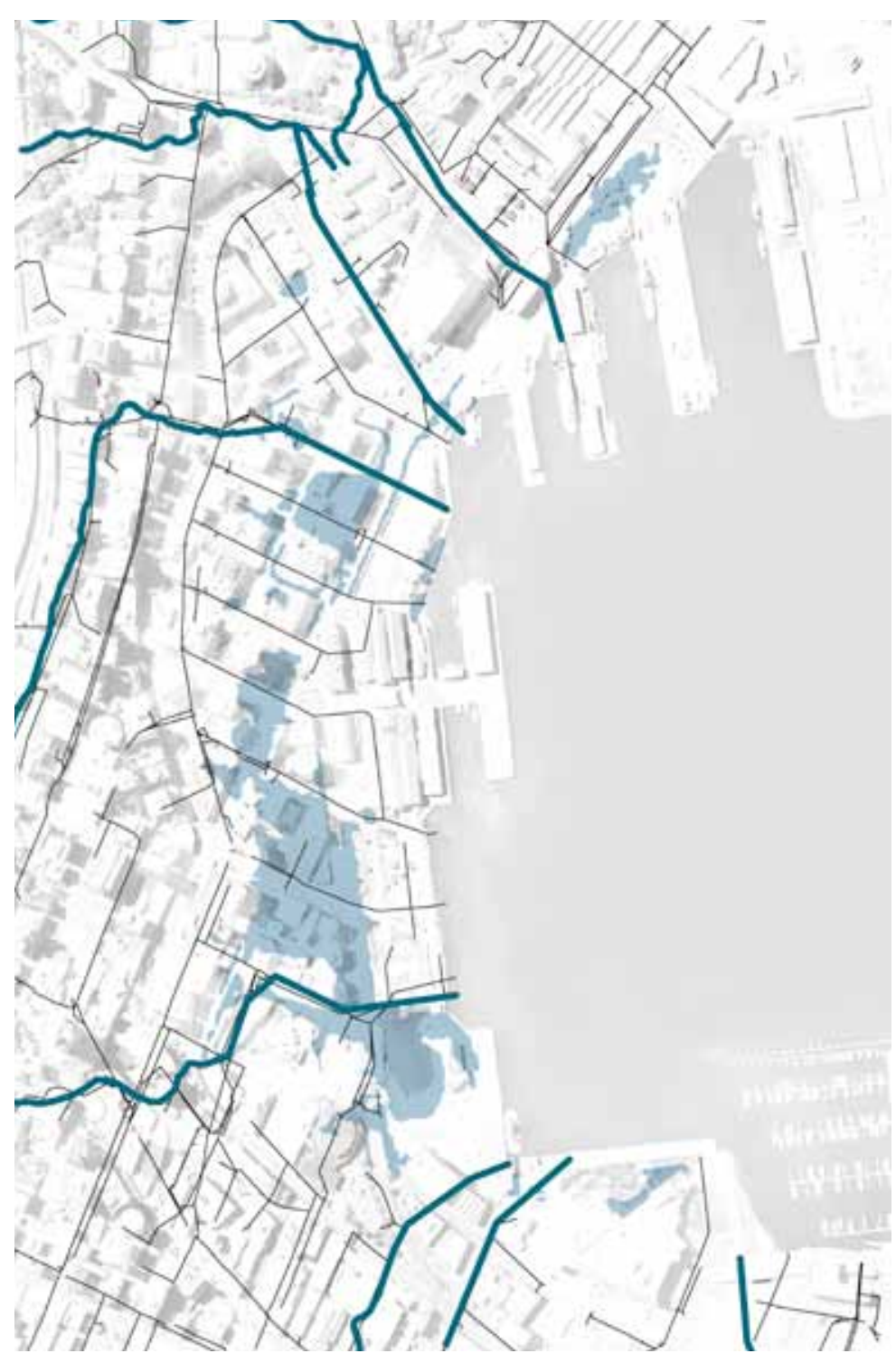

Fig 6.11 Urban streams

- Stormwater pipes Old streams

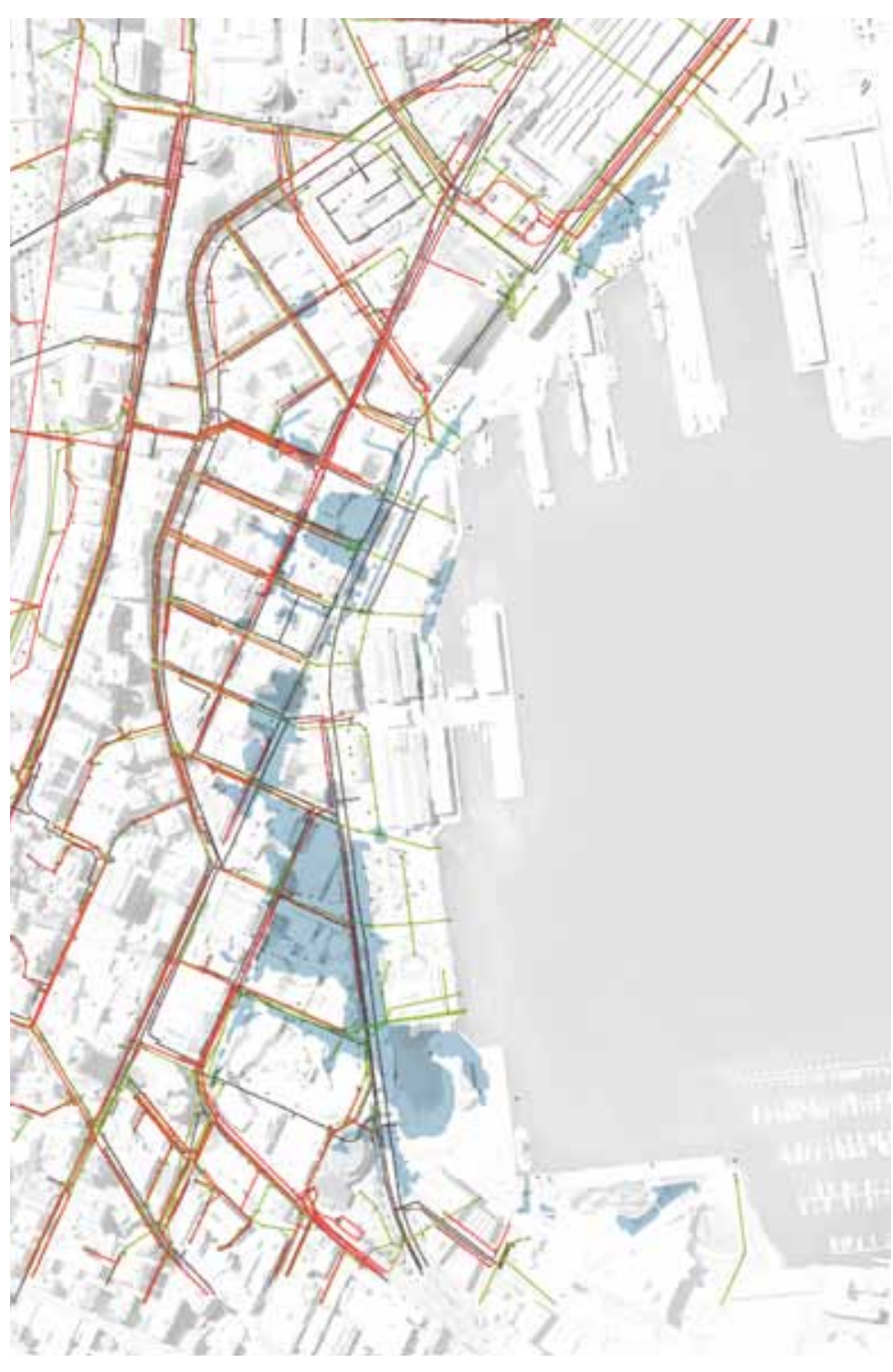

Fig 6.12 Infrastructure

$\because \quad$ Drainage - sewer pipes + nodes

Drainage - stormwater pipes + nodes 


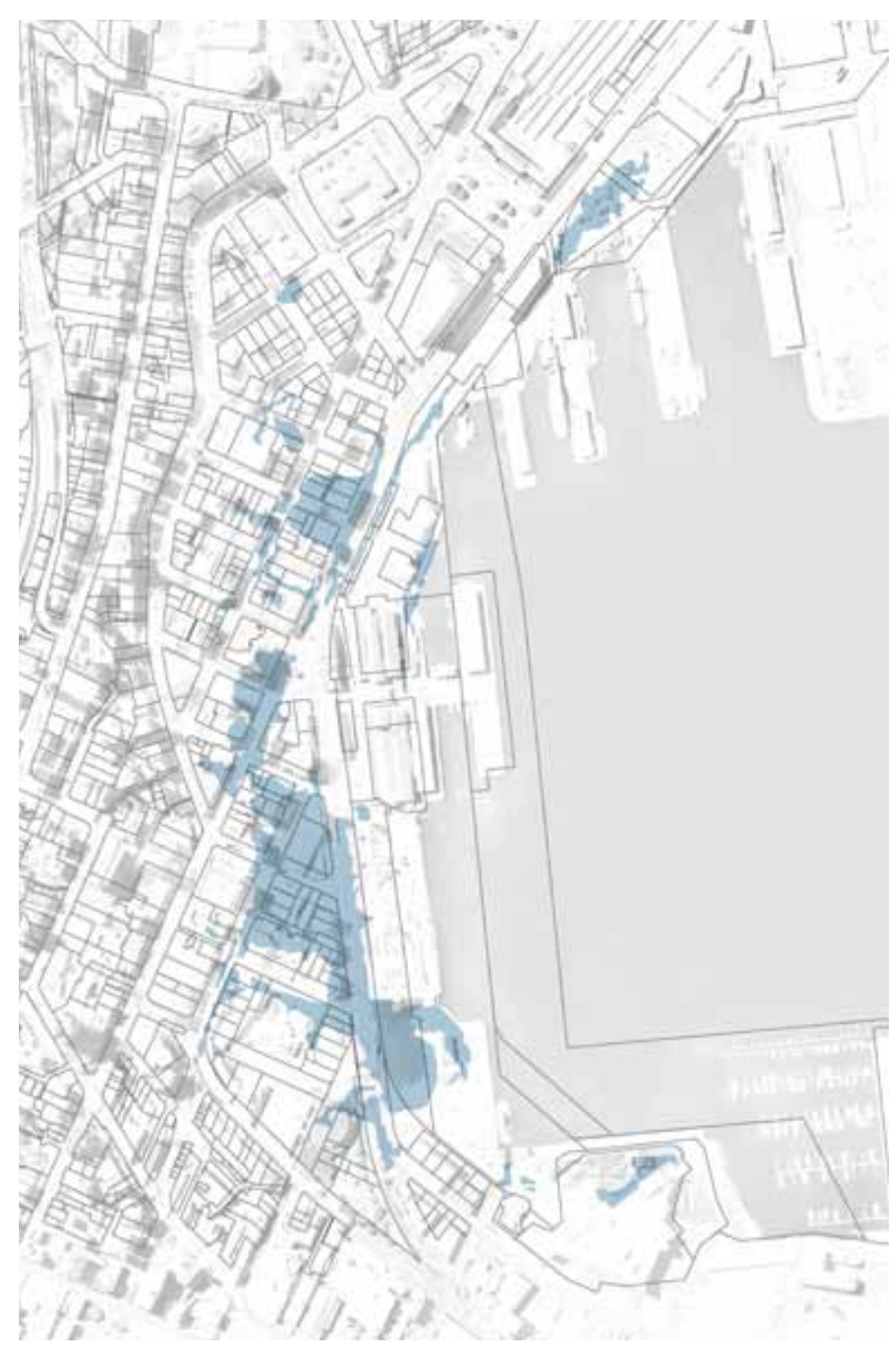

Fig 6.13 Parcel boundaries

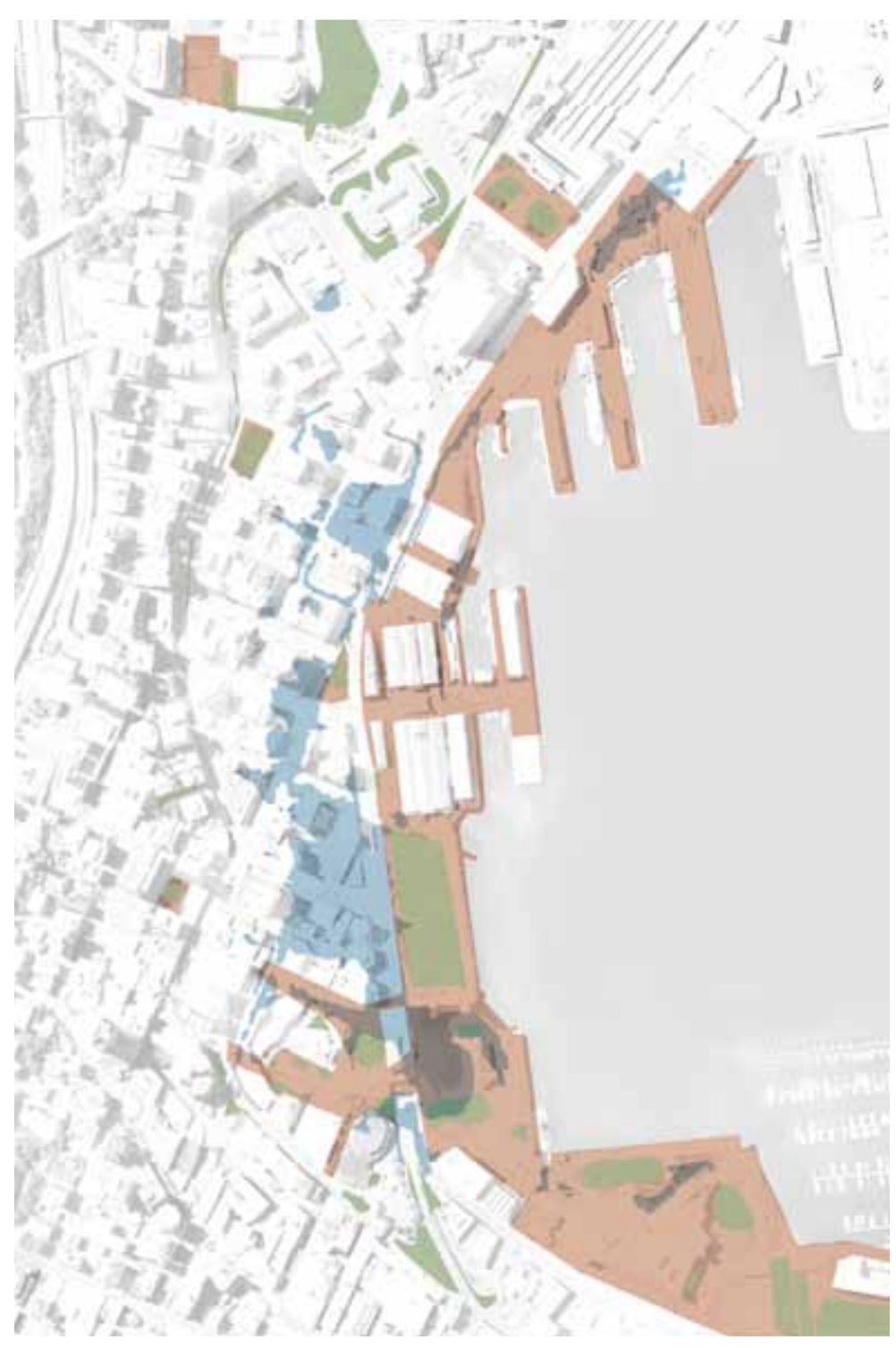

Fig 6.14 Public space

Open public space 
Infrastructure risks are illustrated in figures 6.11 and 6.12. The GIS team at Wellington City Council supplied the data for these analyses. An important requirement of estimating losses from floods is the identification of under-ground infrastructure related to water movement. Figure 6.11 superimposes current stormwater pipes with historical stream pathways, as were indicated in the Mein Smith Survey (1840). Figure 6.12 combines sewer pipes, stomwater pipes and water network pipes (and associated nodes). The maps show that a significant amount of this infrastructure sits on low-lying land, and is at risk to damage and disruption from saltwater intrusion. With a one-metre rise in sea level, damage could occur to this infrastructure daily, at high tide. There is also potential for much more damage to the infrastructure in any storm surge.

Open public space disruption is assessed in figure 6.14. Open spaces are important components of Wellington's visual character. The most dominant open space is the waterfront area, which includes parks such as Frank Kitts Park and Waitangi Park. The central city has a few parks, and a number of city squares such as Civic Square and Post Office Square. Much of the waterfront area is higher than inland reclaimed land. The map shows that a great deal of private property will be affected earlier than much of the city's public space.

Geographic Information Systems (GIS) technology was used to collect, store and analyse a wide range of information. The mapping techniques were relate different types of information in a spatial context and to reach a conclusion about relationships.

A disadvantage of this type of analysis is that it the GIS analysis shows a 'typical' day's high tide. The maps do not accurately predict the effects of higher surges and waves from storms and hurricanes, which are predicted to increase in frequency and severity (Ministry for the Environment, 2001, p. 3).

Although greater in-depth analysis of sea level rise scenarios would be required for true intervention, the studies reported here are sufficiently detailed to test a hypothetical urban design response for Wellington City. 


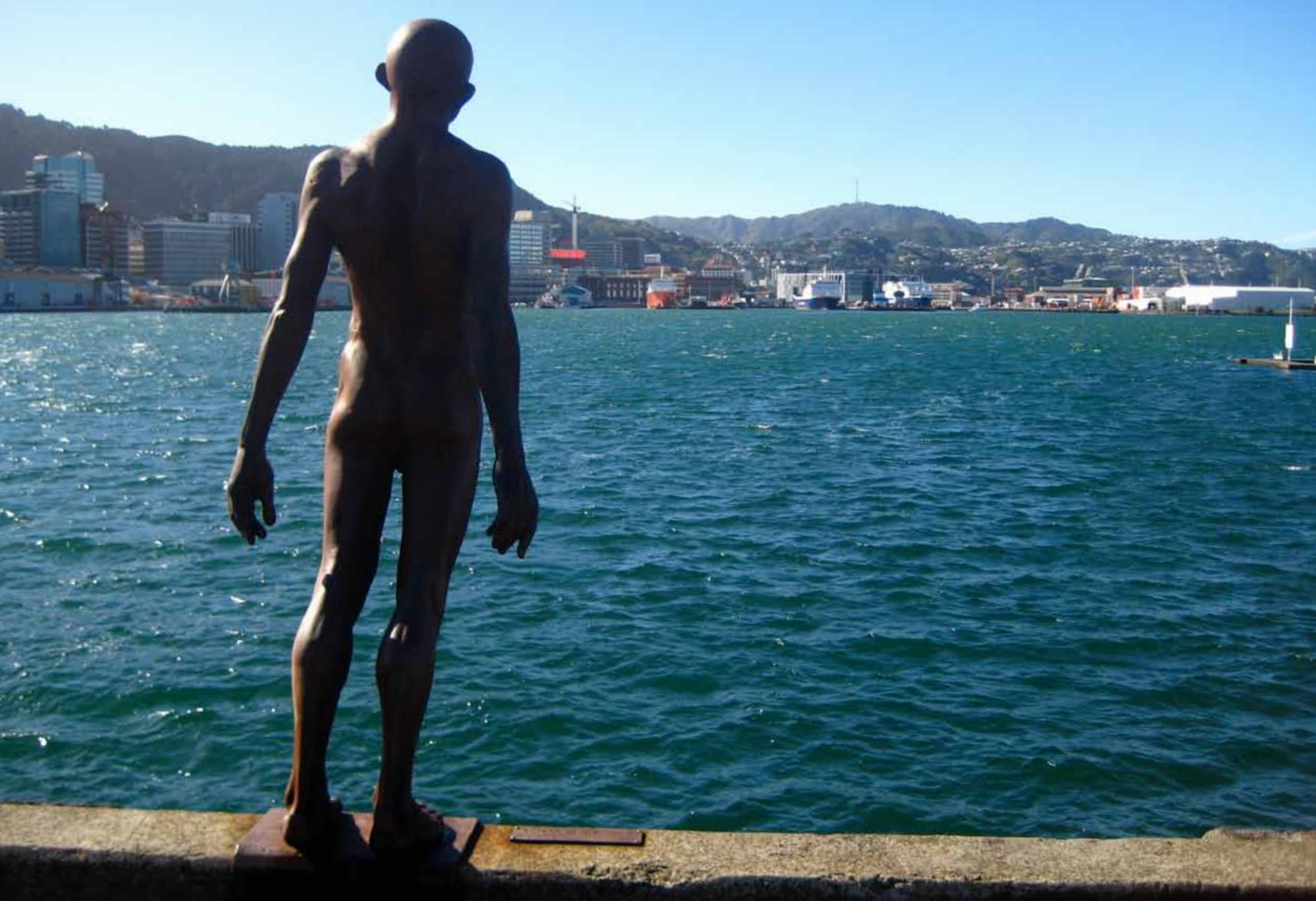




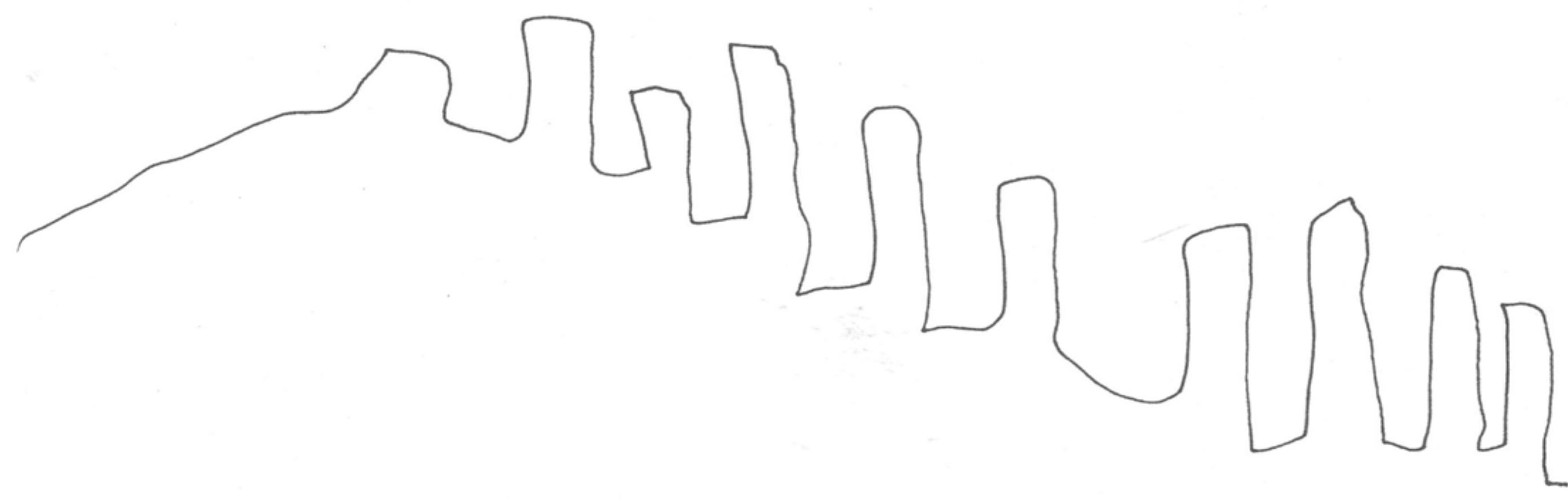




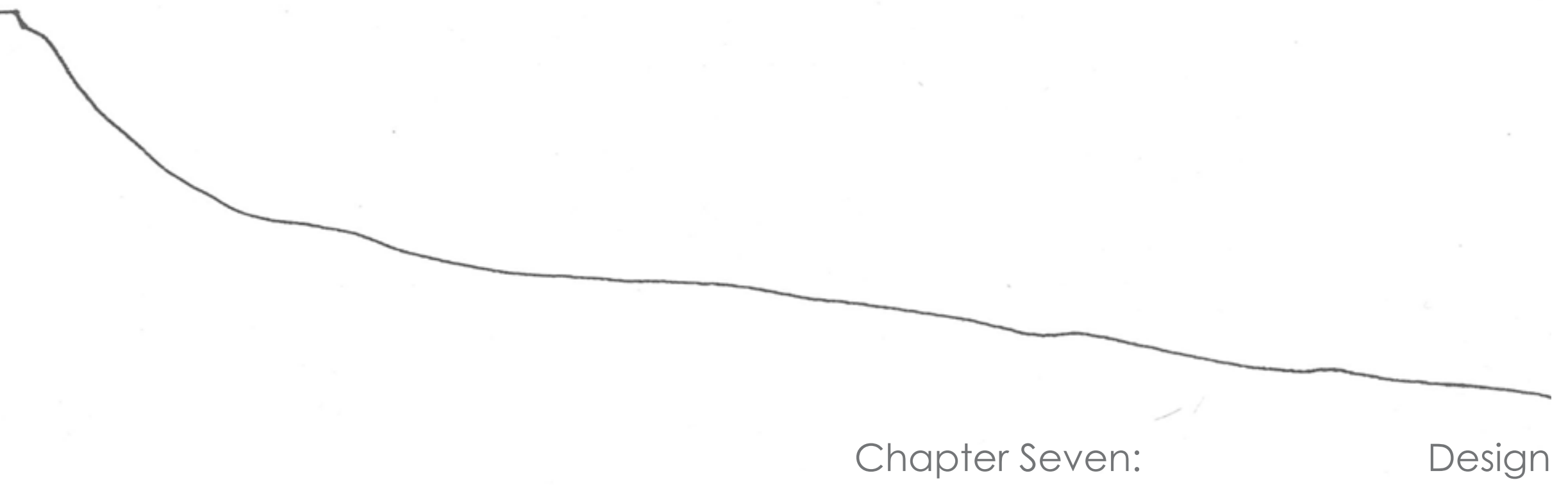


Urban design methodology was used to prepare a response to the scenario of a one-metre rise in sea level in Wellington's harbour by the year 2100.

The purpose of a case study is to test design ideas using a specific scenario. The final design provides an example of how sea level rise may be addressed.

\subsubsection{MAIN OBJECTIVES}

Four main objectives were identified for the design. The proposed response should:

- Increase connections between city and sea;

- Maintain the essential character of Wellington's iconic waterfront;

- Introduce new urban norms that acknowledge rises in sea levels, and;

- Protect the central city from high tides and sea surges. 


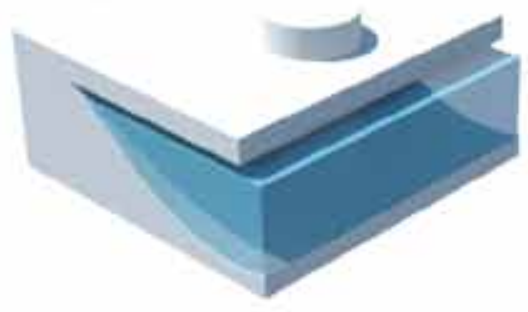

Pier

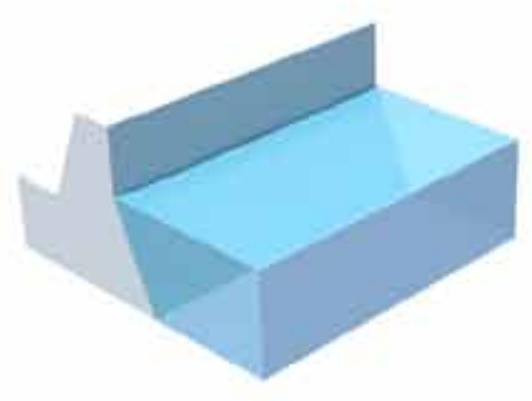

Sea wall

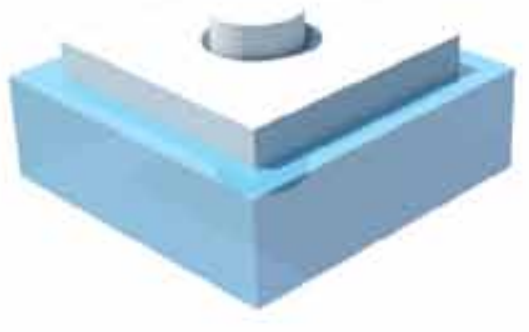

Pontoon

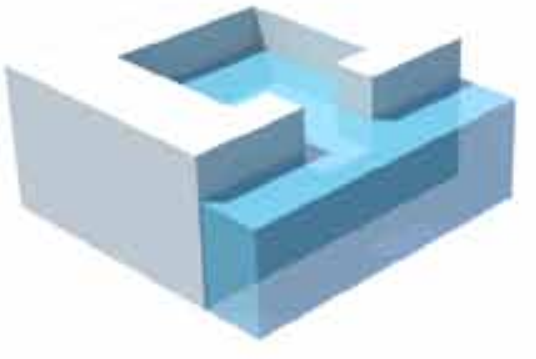

Lagoon

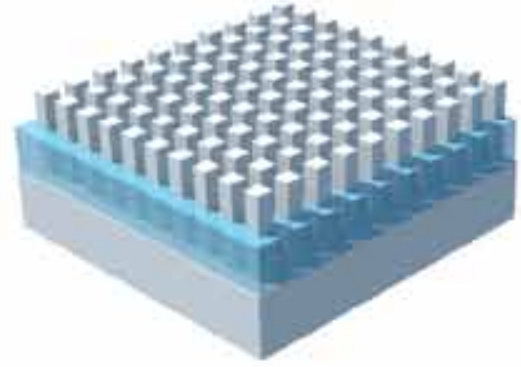

Wetland

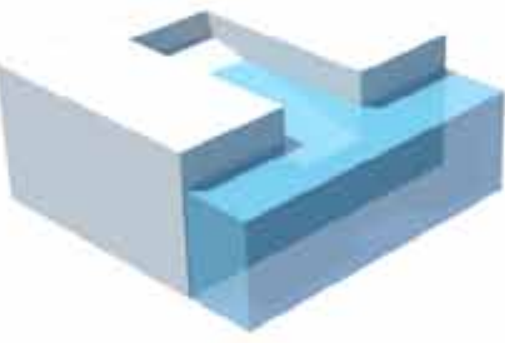

Estuary

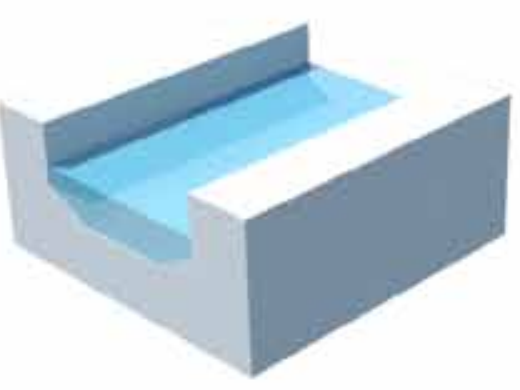

Canal

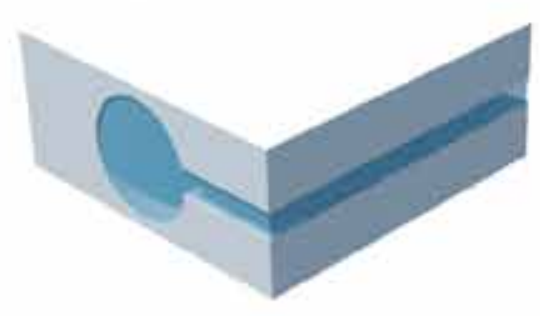

Water storage

Fig 7.1 Design strategies

Catalogue of design strategies for the edges. The edge is

considered to be not just a line dividing water from land

but a zone of altering width. Design process permitted

the experimentation with a mixture of these techniques, in

a number of different forms. 
An early analysis of the site determined how each section of the study site should be treated (Fig 7.2 \& 7.3). Parts of the Wellington City were identified through a typology system according to the level of risk of flooding. Land treatment typologies were created according to the level of risk. Opportunity for further reclamation was also acknowledged.

$\begin{array}{ll}\text { Type A: } & \text { Safety zone: No new response needed } \\ \text { Type B: } & \text { Resiliant area: High risk of flooding } \\ \text { Type C: } & \text { At-most risk area: Floods frequently } \\ \text { Type D: } & \text { Opportunity area: Further reclamation } \\ \text { Type E: } & \text { Sea }\end{array}$

Two contrasting options were considered; to design an incremental response to sea level rise, or an abrupt one. The latter was chosen, because a major response to sea level rise would not be necessary if seas were to only rise by $50 \mathrm{~cm}$. A single defence line could be constructed quickly, as sea level rise predictions become more accurate. The city can continue to operate normally in the mean time.

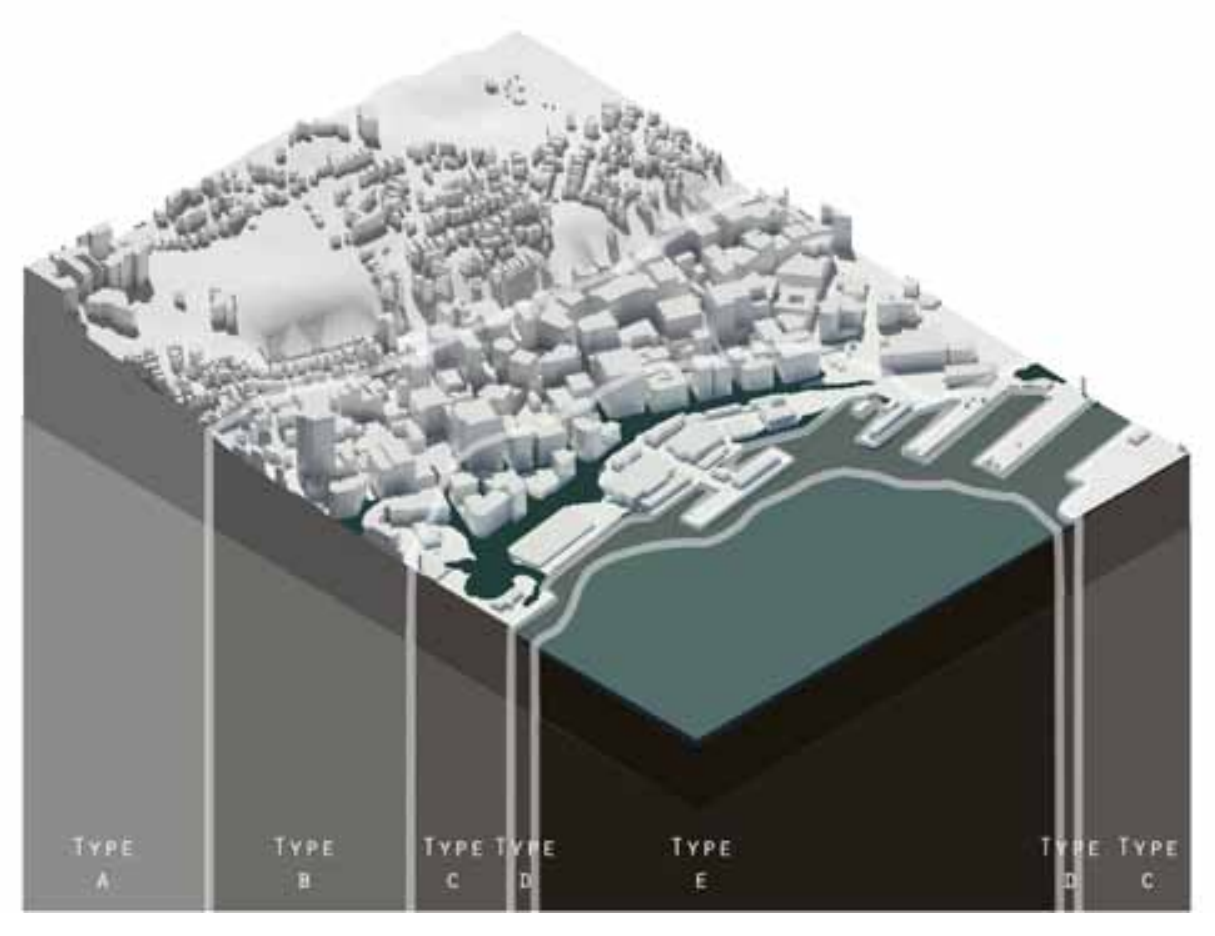

Fig 7.2 Zoning: site analysis

(Left) zoning classification of study site

Fig 7.3 Zoning: one slice

(Right) Futher zoning classification through a sliced section of the site 


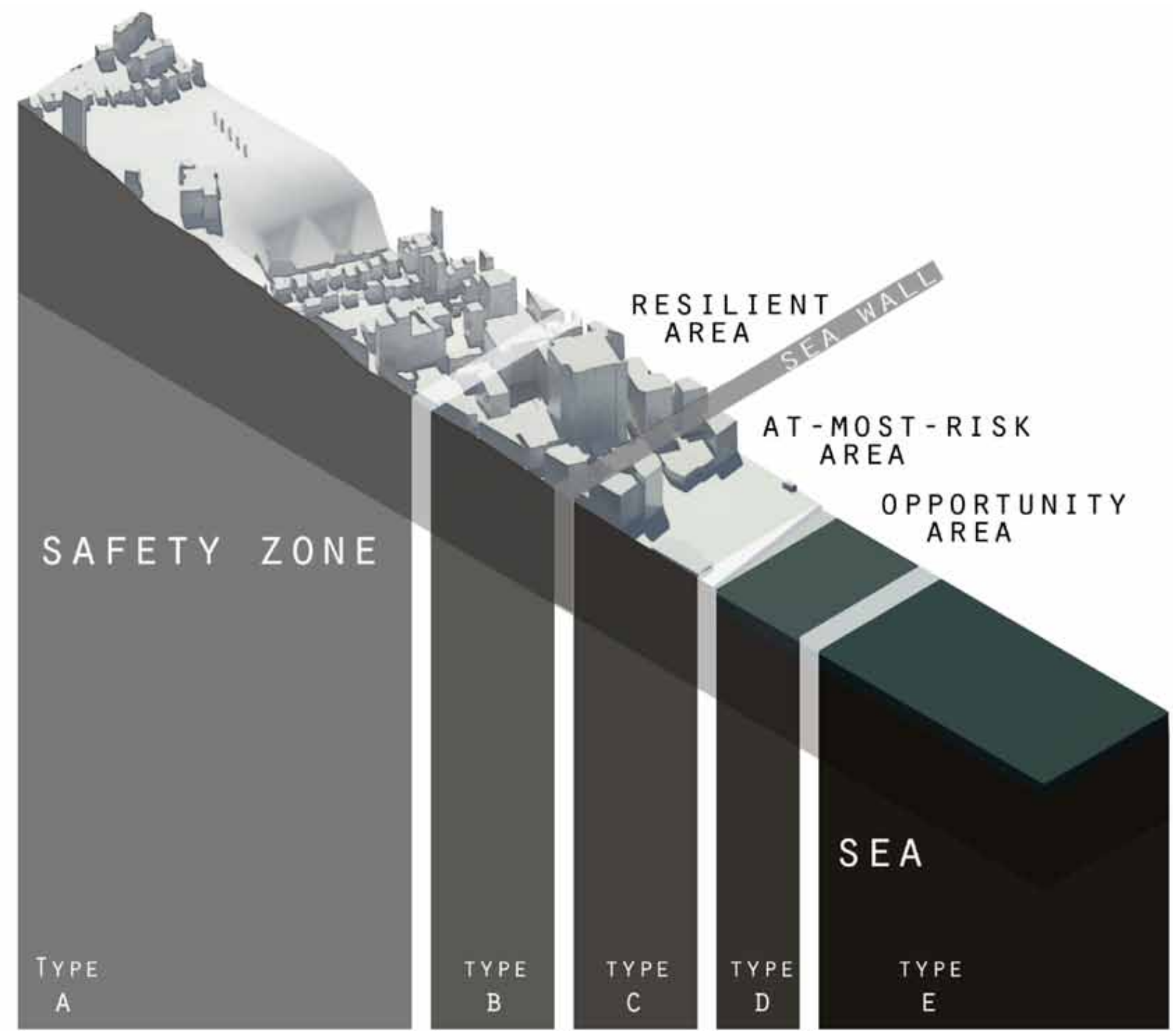


Several alternatives to the traditional form of 'hard' response (i.e. a sea wall) were tested before the decision was made that a sea wall remained the best response for Wellington City. A sea wall was ultimately chosen to be the most effective solution in terms of maintaining Wellington's urban character. It would likely be the preferred option by the general public because a wall can be made to be impermeable. Sea walls have a long track history of success, and can be raised if seas are to rise further than initial predictions.

Key design decisions were made firstly at the master planning level, in response to the design objectives. As the initial objective was to protect the majority of the city, a single sea wall structure was deemed the most feasible and reliable solution for the site. Another objective, being the introduction of new urban norms, allowed for a further accommodation strategy along the harbour's edge. Due to the high social and monetary value of land along the waterfront, no retreat strategy was investigated through the design process.

The placement of a sea wall inside the city, rather than around it, was appealing as it allowed for an unique interpretation of design objective solutions. A new type of sea wall design was tested through the design process. The experimental wall was woven throughout the city, combining artificial and natural urban elements to provide new public space. By using urban design techniques, programs were layered. The structure was tested by computer modeling to combine the notion of 'wall' with 'estuary', 'building', 'park' and 'path'.

The low-lying land in front of the wall was classified as 'amphibious' because of its intertidal nature, and had sufficient space to test new urban design and building typologies. These were similar to the Dutch case studies described in chapter 3. This land would not flood on a daily basis, but was to be designed resilient to sea surges. New roading, public space and building technologies were combined with urban design concepts to create an adaptive landscape along the waterfront. Options for further land reclamation were also investigated.

An initial masterplan design for Wellington City was tested by further developing three small 'slices' of the city (see figures 7.14 \& 7.15). Three public spaces within these slices were then further developed resulting in various amendments to the masterplan design.

The final design result is a large 'indicative' masterplan of Wellington City. Three further-developed sections of the city are designed to act as precedents by which to develop a complete system throughout Wellington City. 


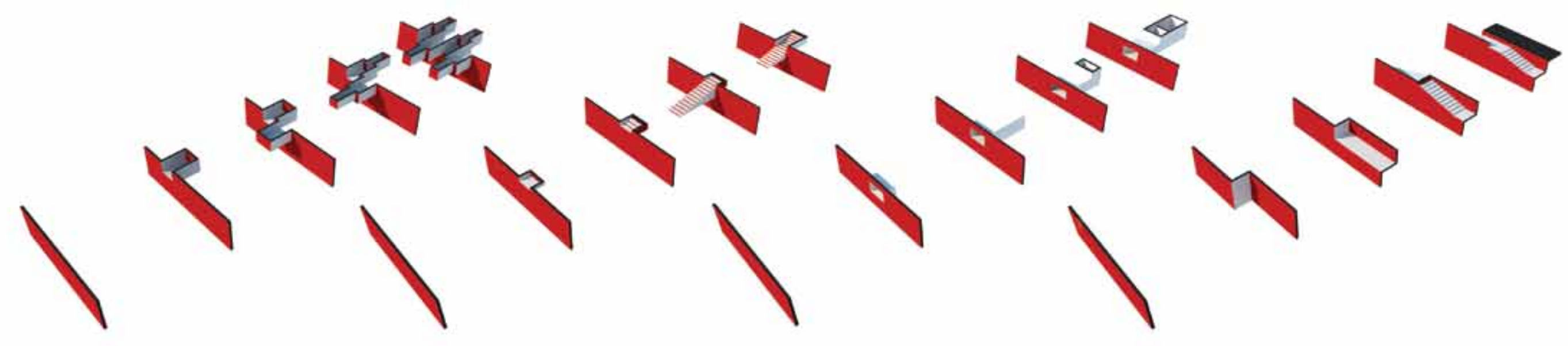

Fig 7.4 Wall studies

Experimentation with the concept of 'wall'. Manipulation of a typical flat wall allows for potentially interesting

spaces. A range of ways of crossing the wall and ways in

which the wall can 'contain' (as well as block)

were investigated. 

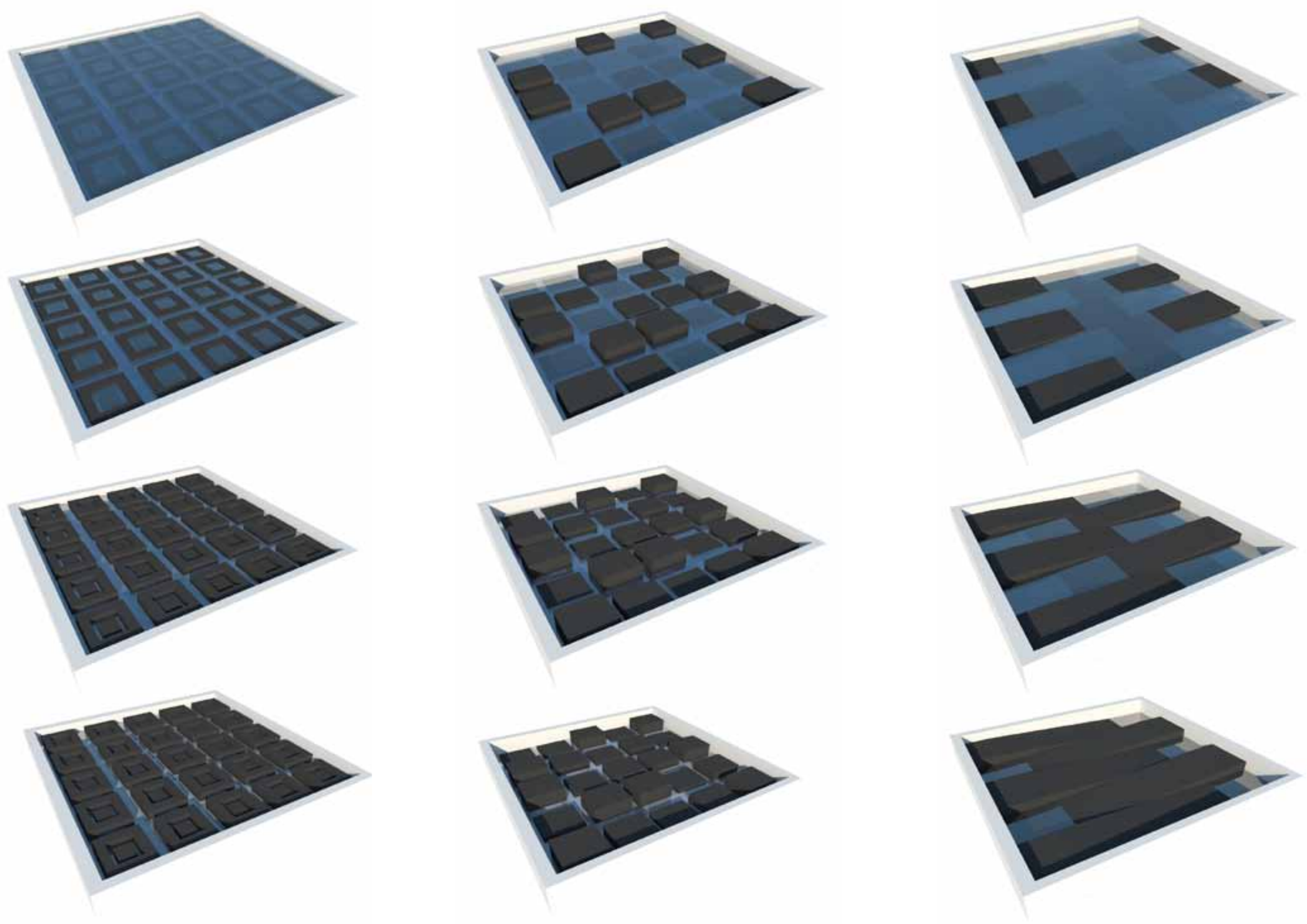
The design responds in two ways to a rise in sea level of one metre by the year 2100 :

- $\quad$ By protecting the existing city

- By introducing an 'amphibious zone'

Protected land is relatively unaffected. Vehicular routes and building processes are similar to the present time. The Amphibious zone is all land the seaward side of the sea wall. With a one-metre rise in sea level this land would not be flooded on a daily basis.

The main infrastructure is a sea wall, which winds itself in and out of the city. As well as forming a boundary impervious to seawater, it is a building, a shelter, a park, and a walkway. It is higher in some places, and wider in others. As a public structure, it promotes visual connections between city and sea and maintains the essential character of the waterfront.

Rather than surrounding the waterfront, the wall sits inside the land. Space has been allowed for eventual flooding in the amphibious zone in front of the wall. This is to direct development towards new buildings processes designed to react to sea level changes. 


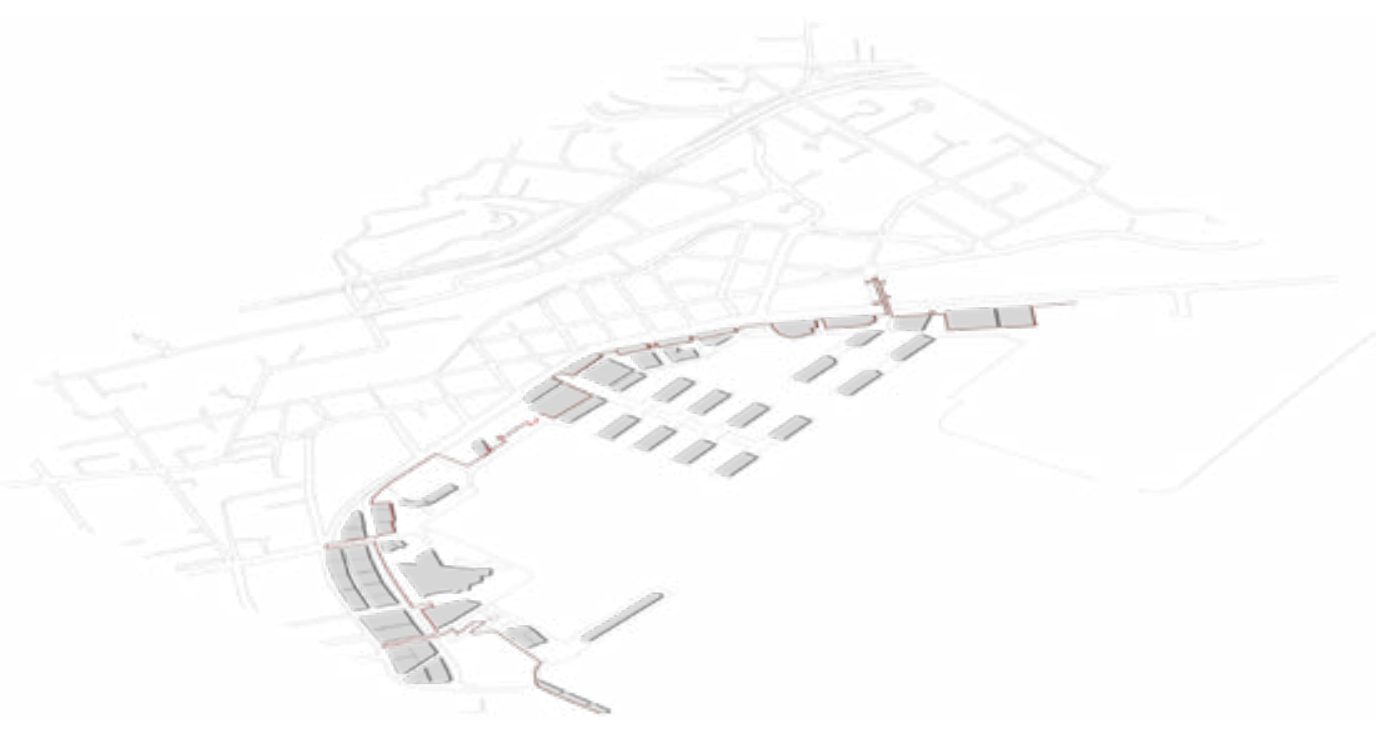

Waterfront buildings

A number of high-quality waterfront buildings remain. New buildings to be built on further reclaimed land, and an increased density of buildings along the wall.

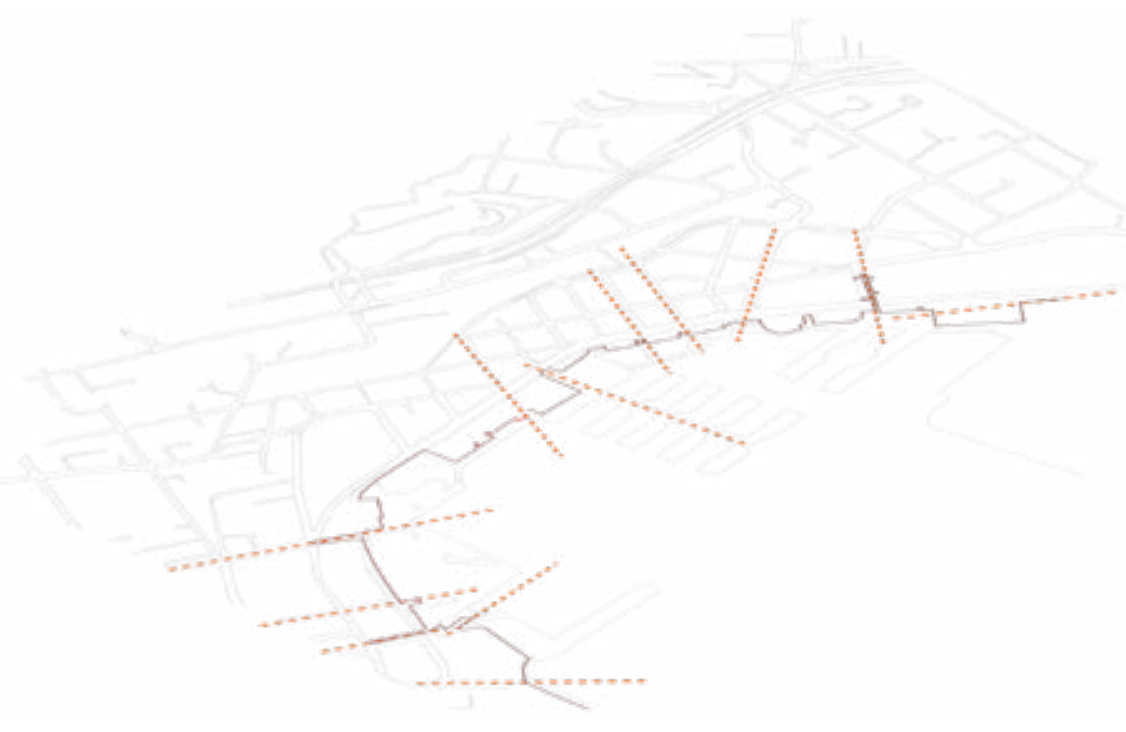

\section{Connections}

Orange lines indicate crossings over the wall. There are numerous crossings for pedestrans and bicycles. There are less crossings for automobiles, which cross primarily at the northern and southern ends of the wall. 


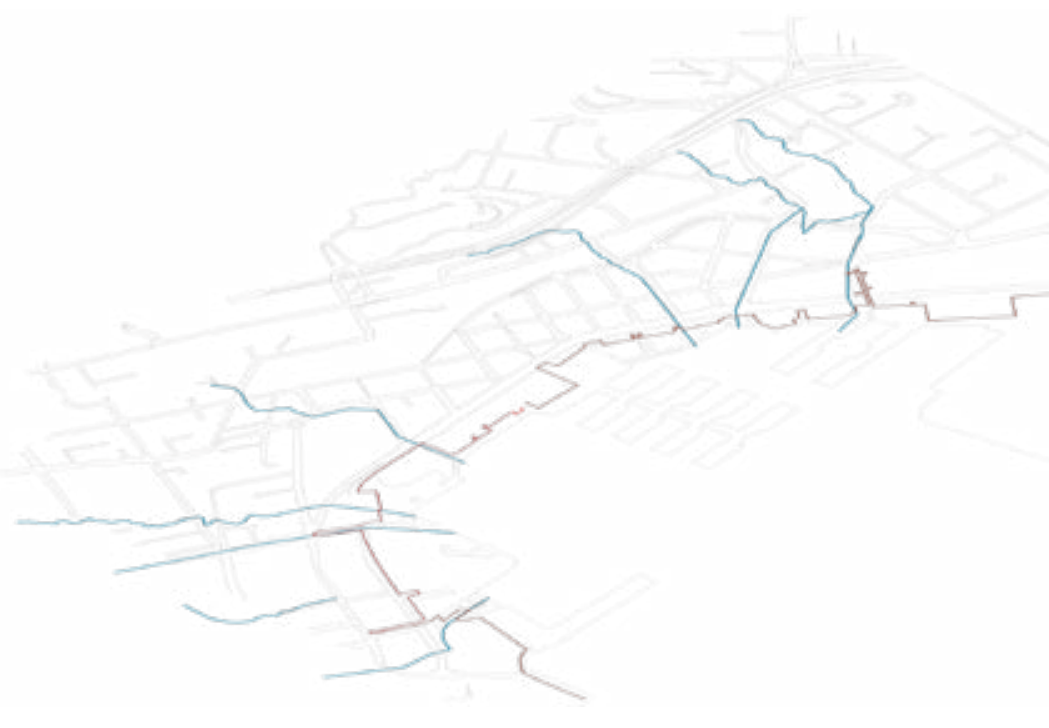

\section{Old streams}

Shape and position of the wall's 'fingers' are influenced by

the location of old stream pathways which now run

underground.

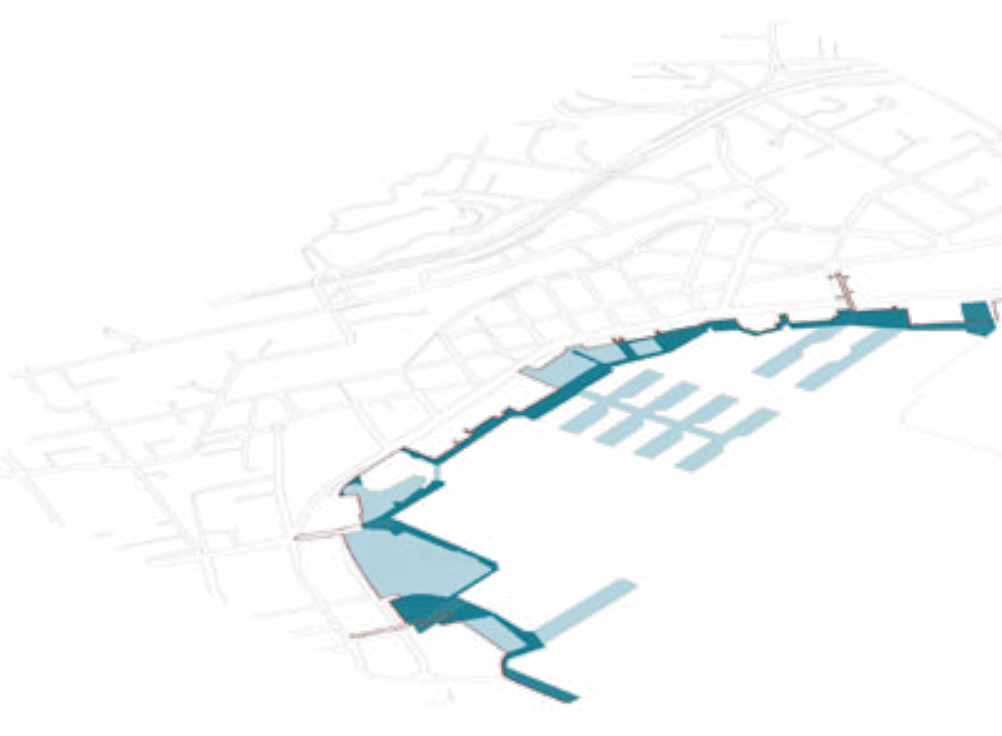

Room to flood

The light blue indicates all seaward exposed land. The dark

blue shows generous areas of space which is set aside for flood drainage. 


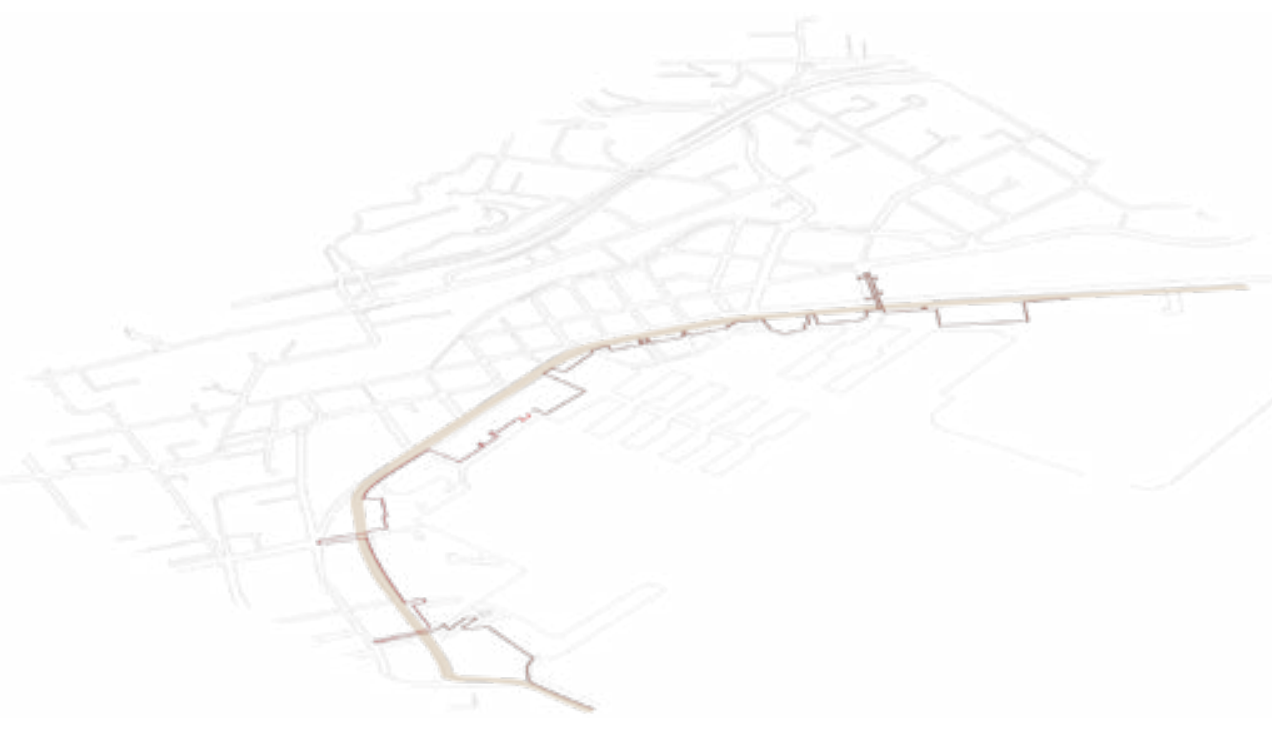

Harbour-front boulevard

Customhouse Quay and Jervios Quay remain in the same

position. However, there are now fewer connections to the

waterfront promenade from this road.

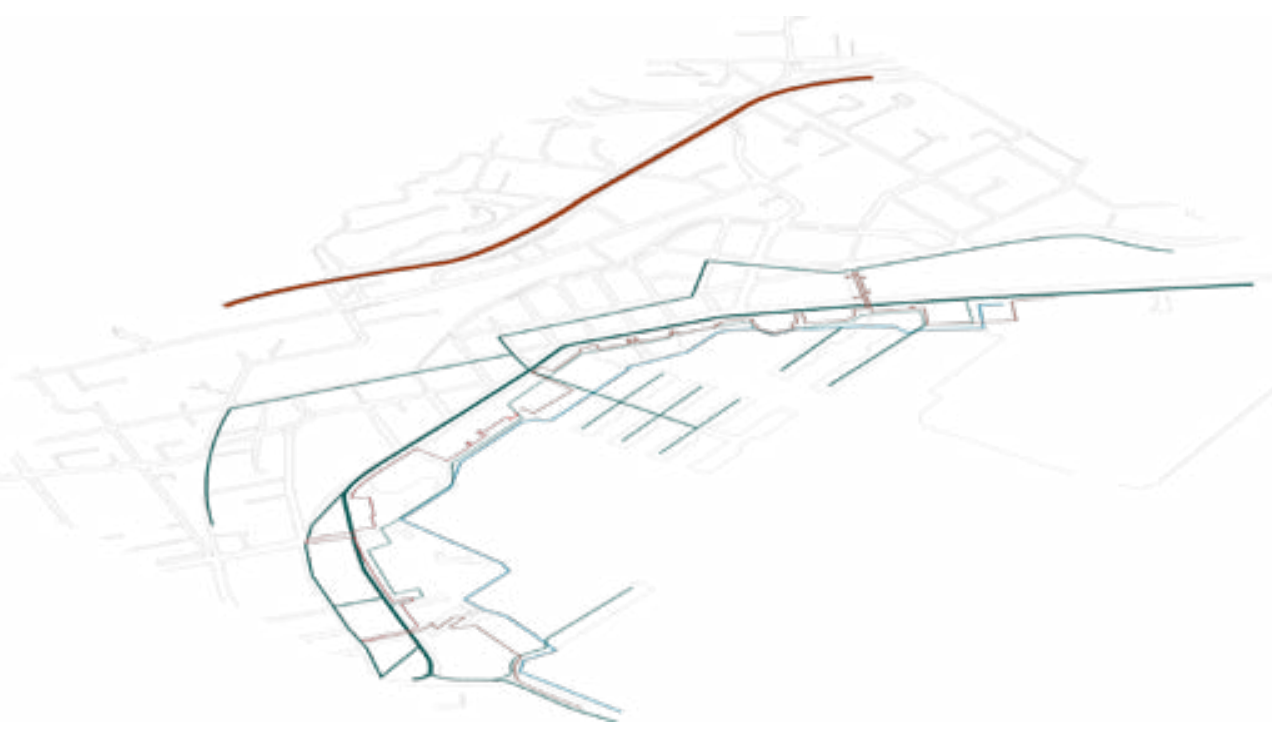

Automobile Circulation

The major-part of Wellington City's transport system is

unaffected by the introduction of a new sea wall. The

mortoway (in red) remains the major link from Petone, and

the major harbour-front road speed is slowed down. New

links are created over/through the wall at Queen's Wharf,

Waitangi Park and northern Kumutoto Precinct.
85 
The sea wall is essentially a standard engineered sheet piling system (see appendix 3). The wall is made of vinyl sheet piling with a membrane liner and drilled down to bedrock up to $15 \mathrm{~m}$ below ground surface. Bentonite will be inserted beneath or around the wall to slow tide changes where needed. The wall will act as a barrier impeding both underground water and surface water from entering the city. Sheet piling has been chosen for the relatively short amount of time needed to construct it, and it can be installed in a small area and drilled down to bedrock without serious damage to surrounding areas.

The wall also uses weathered steel, concrete and weathered timber. These materials are abundant throughout public spaces in Wellington, and help to give a sense of continuity. The wall changes shape, form and function through the city. The following 'slice' designs illustrate how this wall changes throughout the city.

Features of the wall include:

- Encased buildings: The wall is to encase existing buildings, and provide space for new buildings to be built along it. Such buildings will have access points on both sides of the wall. Access points will be safeguarded by floodgates (see appendix 4) that lie flat on the ground, to be raised only if necessary. Where the wall encircles existing building walls, it will mimic their form and composition, with a thin strip of weathered steel (cladding) to indicate its presence (see figure 7.25).

- Estuary fingers: Using the concept of an estuary, ${ }^{1}$ the wall enters the city through a number of 'fingers'. Containing natural flora (see figure 7.44), these would require modest operational attention while filtering polluted runoff. They will provide visual connections from within the city to the sea, public space for leisure and recreation, and act as a public educational tool; recording long-term and daily tidal fluctuations. Allowance should be made for failure of Wellington's stormwater system by providing space for water to be stored and treated in the lateral area before exiting into the harbour.

- Access points: Access points along the wall provide for pedestrians and automobiles to enter and exit the amphibious zone. Floodgates for crossing for disabled persons and automobiles (appendix 4) lie flat on the ground and are to be raised only when necessary. Ramps and stairs cross at regular points along the wall.

- Public infrastructure: At most times the wall is a public element, accessible to everyone. The wall's form changes to provide for public pathways, seating and shelters in different areas. one or more rivers flowing into it and with an open connection to the sea. (Nordenson, 2010) 

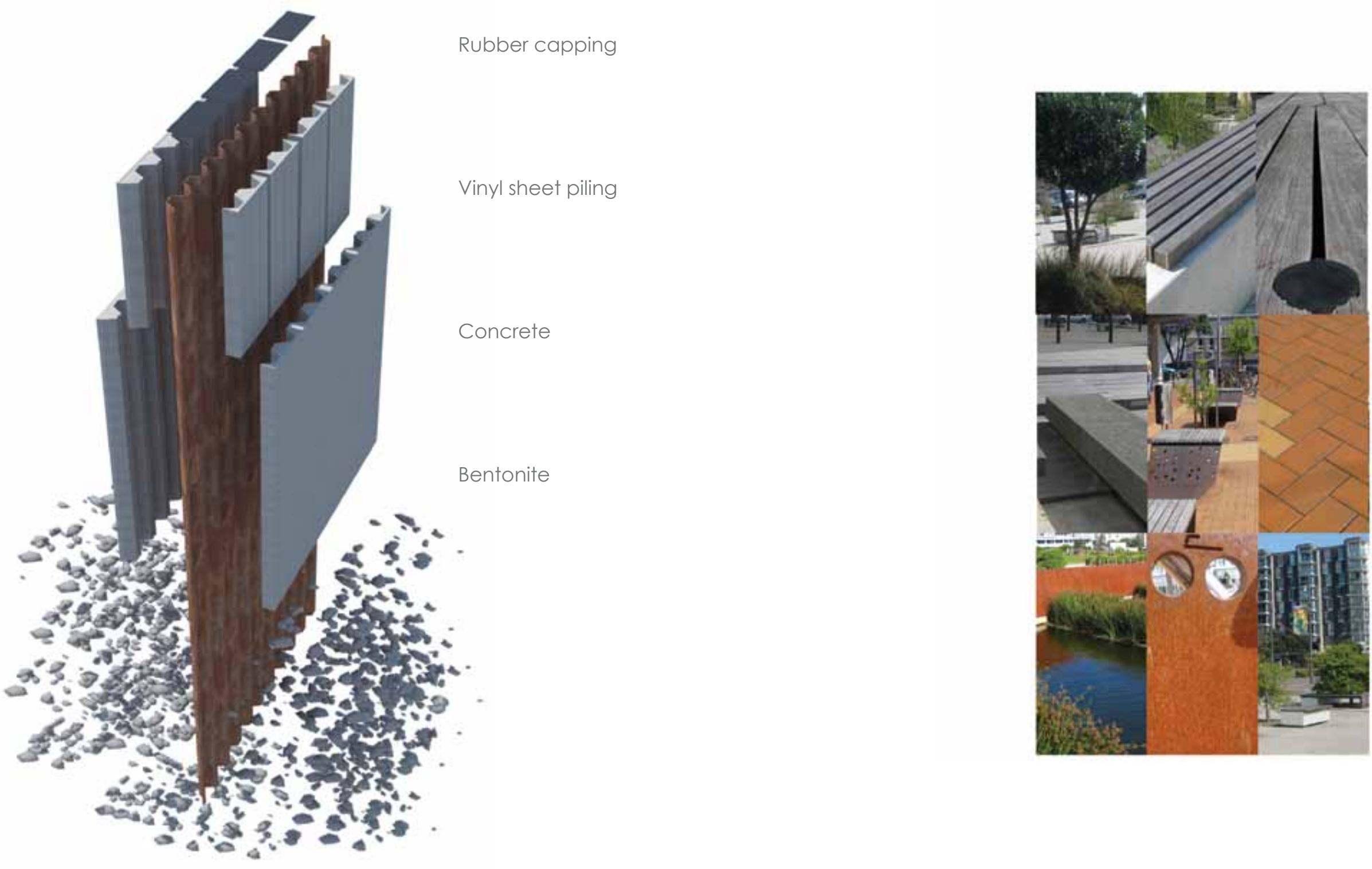

Fig 7.8 Wall construction

Fig 7.9 Wall materials.

(above) Materials similar to current waterfront 'theme': Corten Steel, Weathered timber, white concrete and exposed aggregate concrete. 
The aim of the Amphibious zone is to direct urban design and building process to become more resilient to sea level rise. The aim of this space is to create an area of experimentation where designs can be tested and improved. Due to waterfront development companies and retention of land ownership, this land would be an appropriate place to test novel response strategies.

Development of the amphibious zone will be governed by controls that encourage new urban norms. By allowing valuable waterfront land to become periodically flooded, building processes will evolve to deal with rises in sea level, and Wellington can hope to establish itself as an innovative centre for future building technologies.

A specific building code or framework would be needed for construction development along the amphibious land. Existing exposed buildings must be evaluated to see if they would withstand periodic flooding. Some buildings may need to be retrofitted and others replaced. The council could continue to encourage high quality public spaces, and buildings, and a framework could be created to encourage resilient infrastructure designed to adapt to sea level changes.

Features of the Amphibious zone include:

- $\quad$ Resilient architecture: Medium-rise and mixed-use buildings with strong supporting structure of concrete-encased steel. High ceilings and wide floor spans. Services located in wet-proof areas. Access to second storey in event of flooding. Lower vulnerability uses located on ground floors.

- Intertidal land: Land covered by daily tides set aside for intertidal habitat and grazing marsh such as wetlands, gravel beaches, vegetated rocks and salt marshes. Constructed wetlands designed to work apart from existing drain and sewer networks; they improve water quality by removing pollutants from stormwater runoff and supplying nutrients to surrounding waters. ${ }^{2}$ Saline tolerant plants on amphibious land would include;

- Karaka (as on Taranaki Wharf)

- $\quad$ Pohutakawa (small variety as at Waitangi park)

- $\quad$ Taupata (as at Waitangi park)

- Knobby's club-rush (shrub thriving in gravel)

- Flax (Phormium cookianum)

- Saltwater tolerant freshwater Wetland species sourced from Pencarrow Lakes in the greater Wellington region ${ }^{3}$
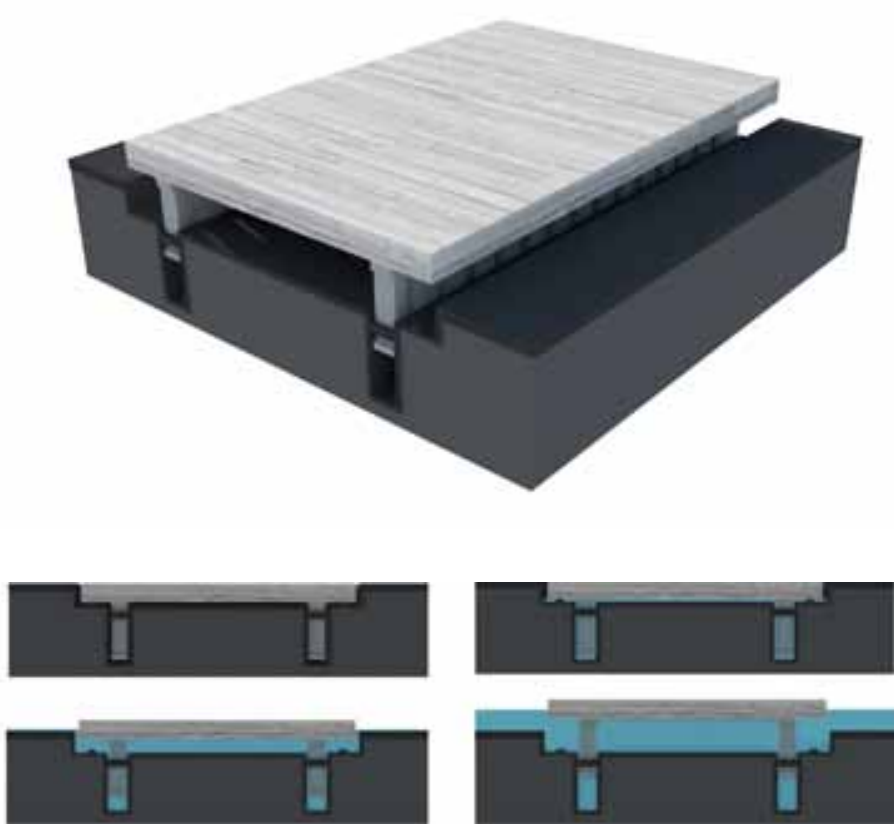

Fig 7.10 Floating road

(above) This road to be constructed along main routes. The platform is designed to float only in times of extreme flooding
Salt marshes and wetlands can produce and fuel both terrestrial and aquatic flood webs. Further, Wetlands are predicted to respond well to rising sea levels (Pilkey, 2009, pp. 101, 102).

The Pencarrow Lakes, in Greater Wellington, used to be salt-water valleys. Around 7000 years ago, barriers formed at the mouths of the valleys, and they were cut off from the sea to become freshwater lakes. The lakes have been brackish/freshwater for about $4300-5000$ years. The two lakes, and their associated swamps contain extensive communities of salt-tolerant wetland plants, among those 16 regionally endangered plant species. (Greater Wellington Regional Council, 2007) 


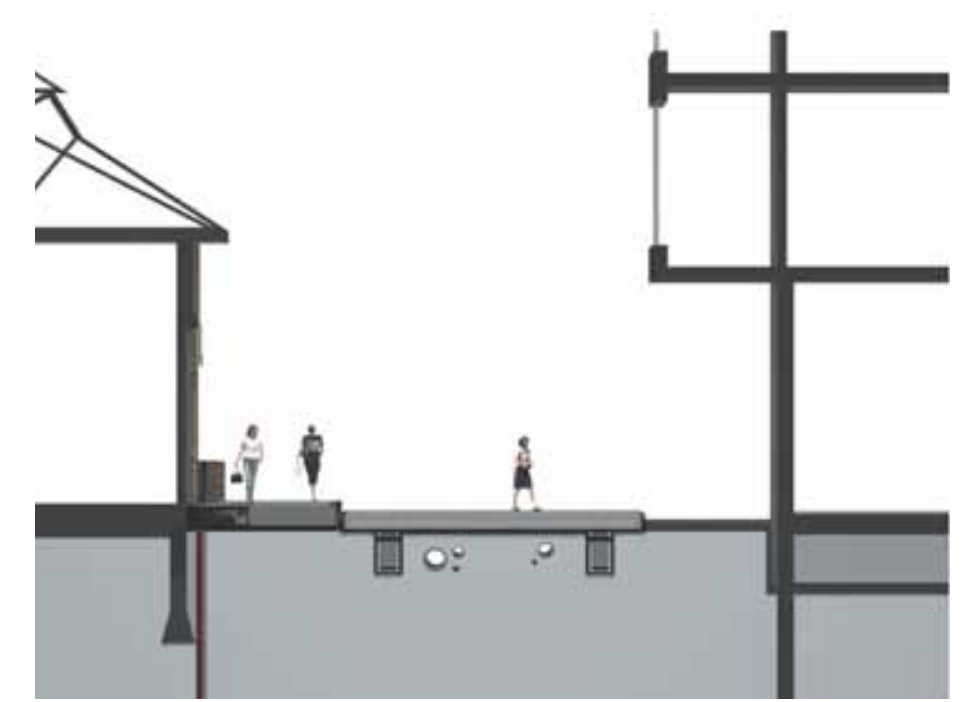

Typical day

No water will enter landscape

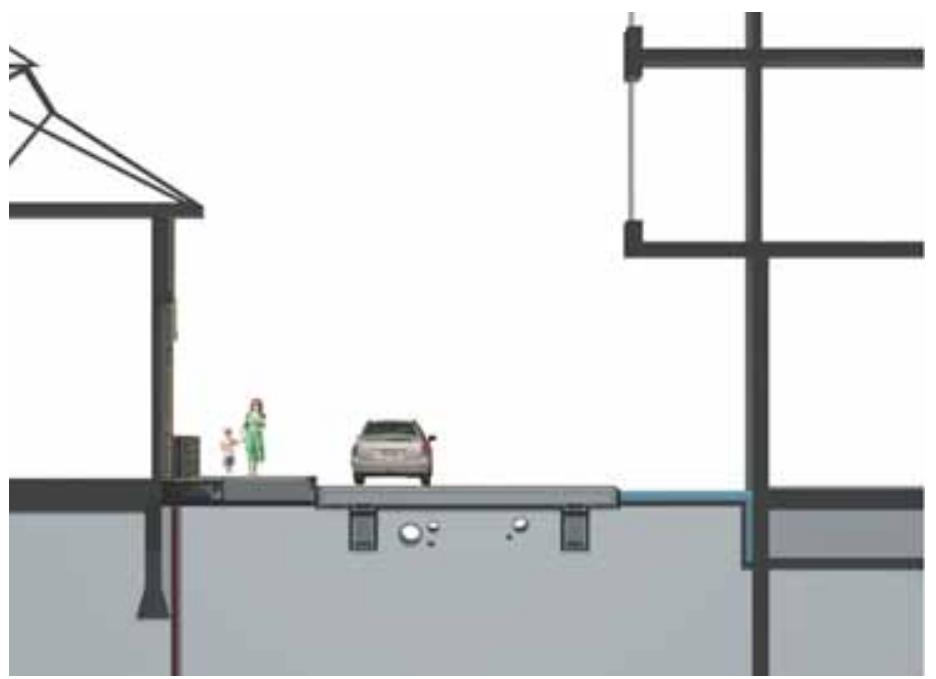

\section{Unusually high tide}

Some tidal water will enter landscape

Terraced street pattern permits quick drainage of sea water Main promenade is raised for safe access

Protection offered to heritage building (left) by high concrete walkway

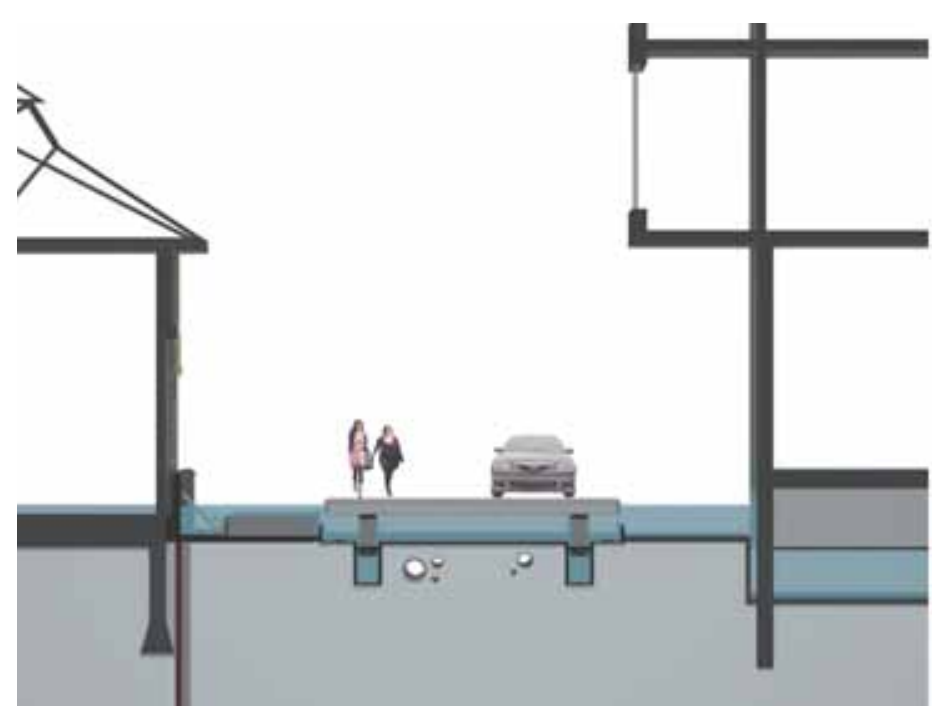

Extreme High storm surge ( 1 -in-100 year storm)

Tidal water will enter landscape

Main promenade raises to float above water

New building (right) raises off foundations to float on water

Flood gates surrounding entrances in heritage building (left)

This series of sections displays an area of the Amphibious zone.

The land will not be flooded on a daily basis, however is designed

to adapt in time of high sea surges and storms.

A heritage building (Shed 11) is shown on the left, and a new

building system is shown on the right. The new building uses floating

foundation technology. 


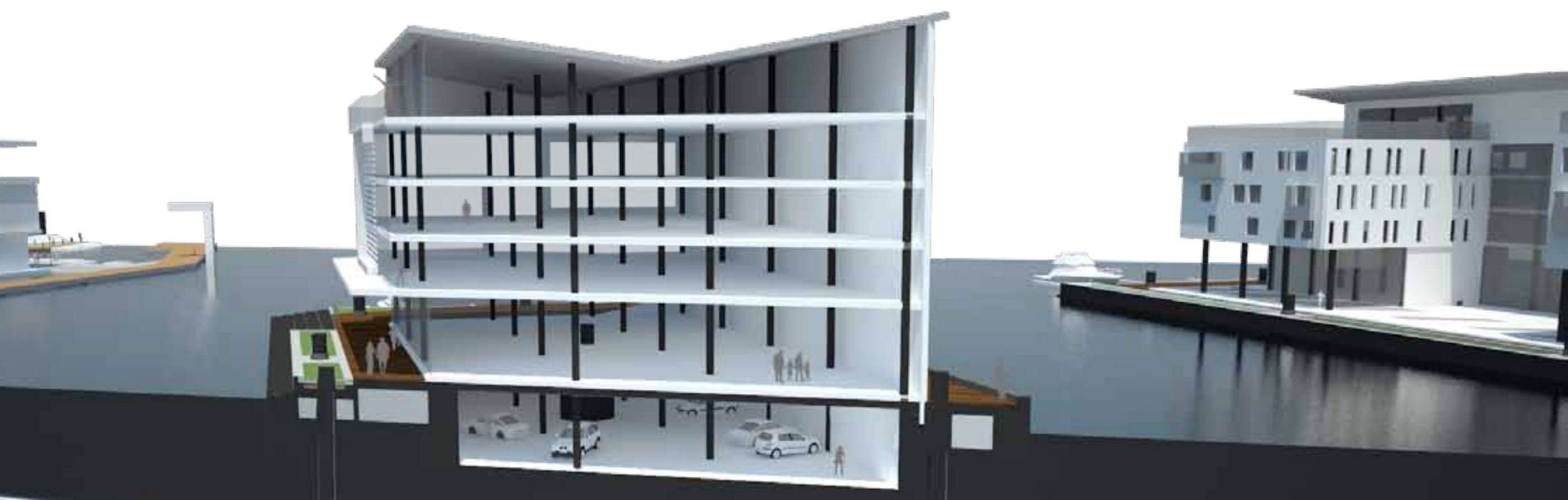


- New circulation patterns: Exposed streets now shared by slow speed automobiles, pedestrians and cyclists. Exposed land terraced to create generous areas for rapid drainage. Main access routes on higher ground perpendicular with harbour containing expanded polystyrene (EPS) blocks ${ }^{4}$, designed to rise in the event of flooding.

- Further reclaimed land: Future reclaimed land to be raised on piers, which float over water supported by widely spread piles. This new structural system is indicative only. Uses expanded polystyrene (EPS) blocks (refer to appendix 2) and underwater basement for buoyancy. Land designed to rise and fall with sea fluctuations, and like a pier, could create effect of breakwater, reducing intensity of wave action (Nordenson, 2010, p. 106). Saltwater impervious wide-span framing. New land funded by private investors, providing revenue for council.

- $\quad$ Risk minimisation strategies: Non-vulnerable items on ground floors (e.g. cafés, car parks and circulation space), with office and living spaces above.

- Floating waterfront promenade: Unbroken promenade along waterfront. Ample space for slowmoving cars, pedestrians, skaters and bicycles. Promenade elevated 0.1-0.3 metres above most amphibious land, creating terraced area for flood drainage. To be made with expanded polystyrene in its centre. Will rise and fall in extreme tides for safe access.

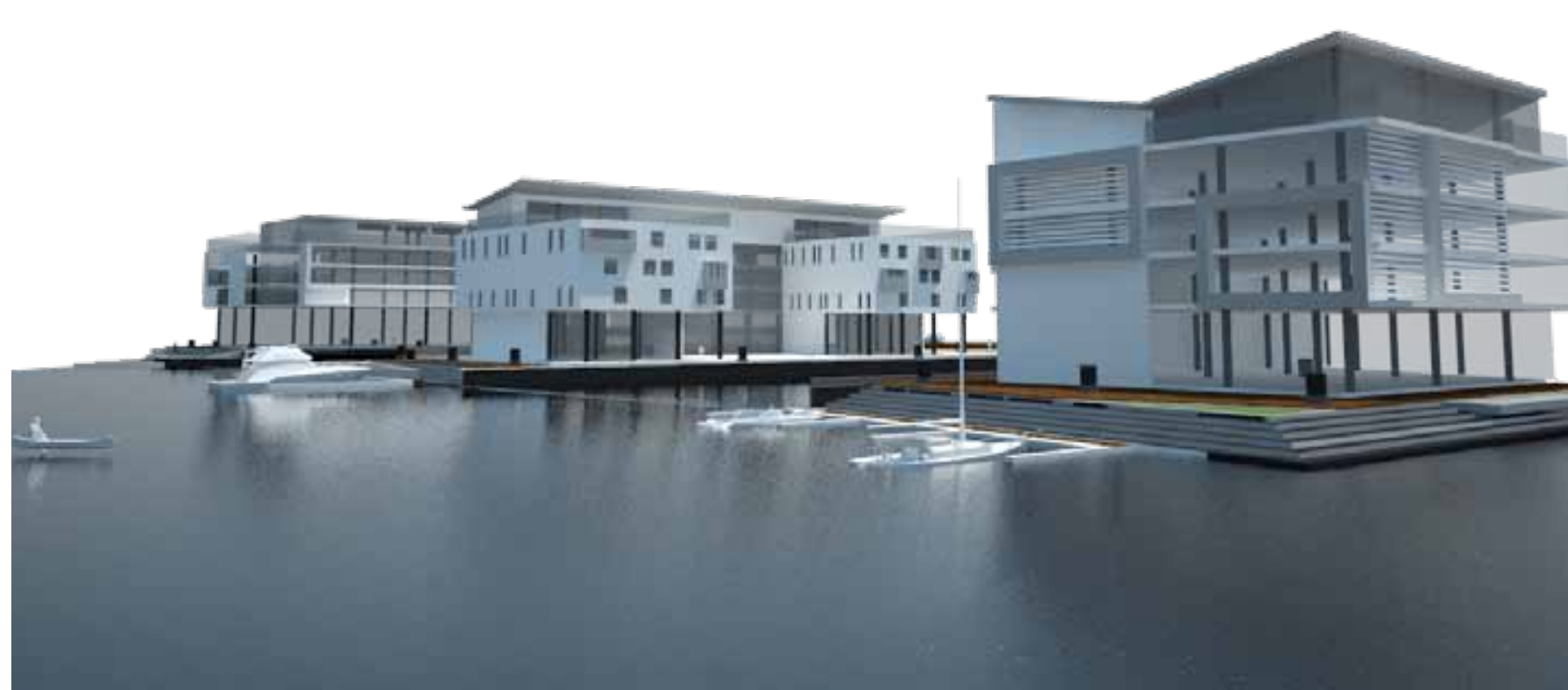




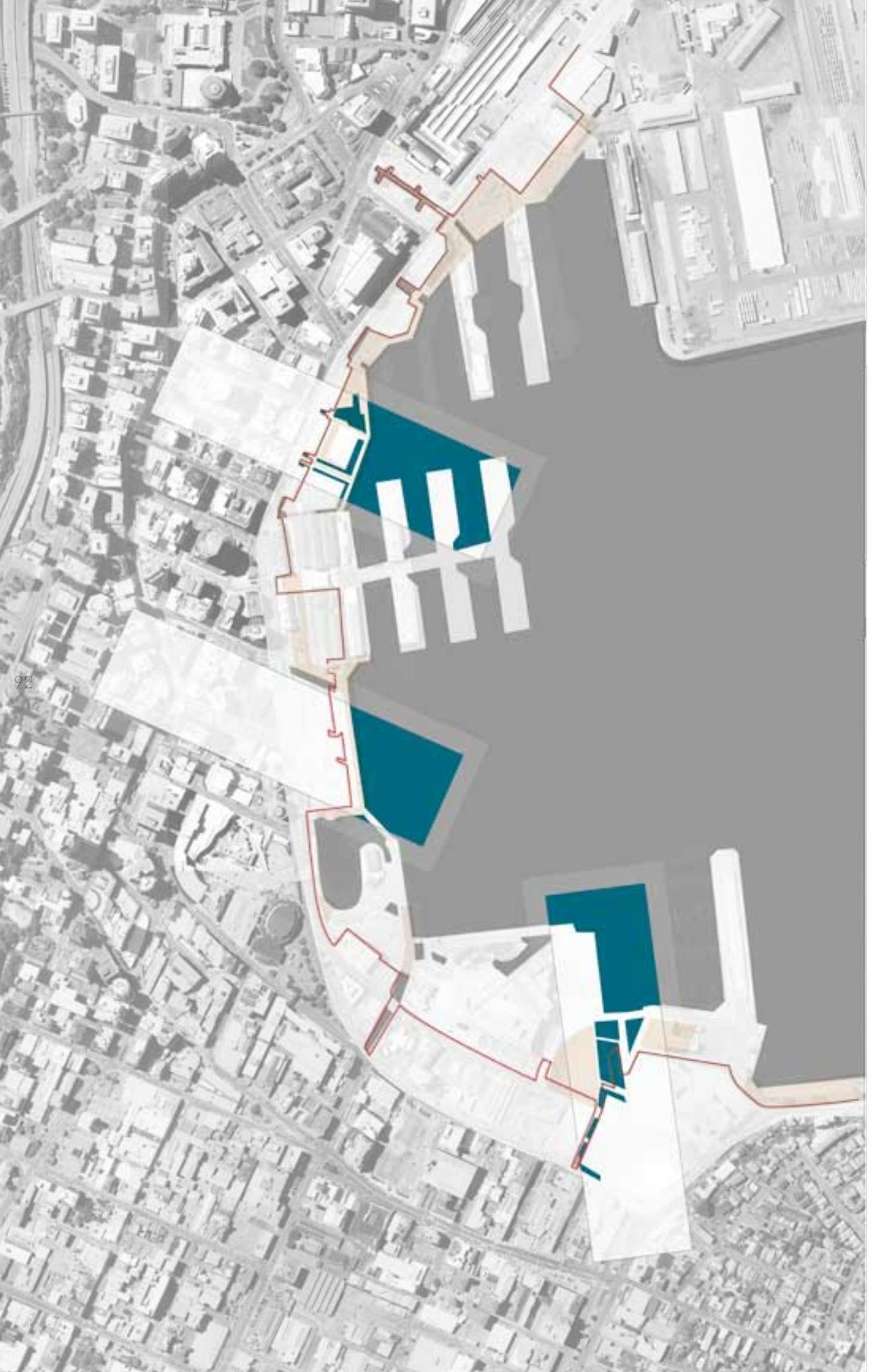

The following designs are three further-developed 'slices' of Wellington City. The slices have been chosen for their vairety in terms of wall and land treatment. They are designed to act as precedents by which to develop a complete system throughout Wellington City as indicated in the masterplan. 


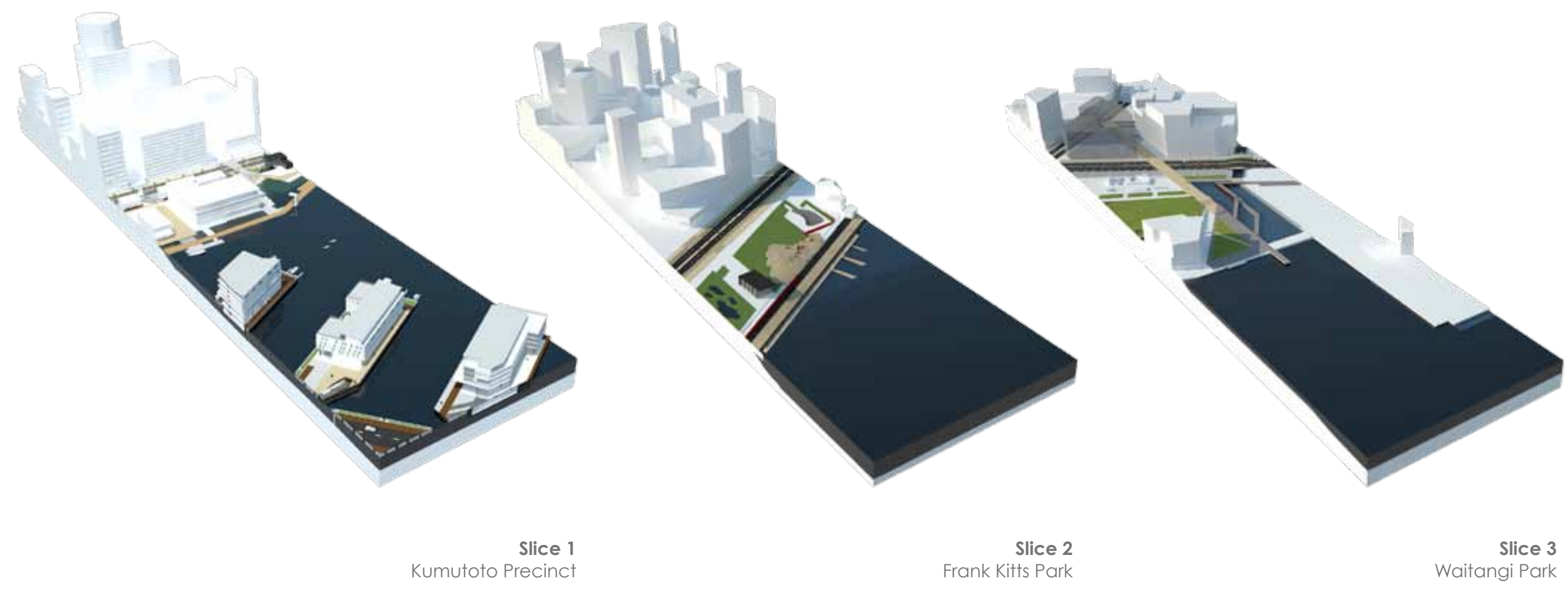

Fig 7.14 Masterplan

(left) Red line= sea wall

Yellow shading= room allowed for flooding

Fig 7.15 Slice overviews 
Kumutoto Precint is the most northern of the slices. It also contains the latest of the Wellington waterfront developments. The waterfront area is adjacent to densely packed high-rise buildings. It contains two buildings constructed in 2006 - an office block with two cafés (north) and a building housing a number of restaurants (south) - as well as two heritage buildings, which are historic sheds used for shipping.

Almost all outside space is public, and has also been constructed recently. This popular space is an award-winning day-time destination. The area has a mix of trees, low level planting, seats, timber walkways, and an iconic bridge. The central city successfully connects with the waterfront.

All land is reclaimed and is relatively porous. Part of this land to the north of the site has recently been declaimed, revealing a portion of the old Kumutoto stream.

The proposed sea wall design seeks to preserve the nature of this newly iconic area, while celebrating the rise in sea level. The wall is set back from the public spaces, and is wrapped around the existing heritage buildings.

At the northern end of the Kumutoto site, a new building is introduced with a similar floor plan to the heritage buildings. All three buildings which the wall wraps around are accessible from either side of the wall, as access points are safeguarded from high waters by a terraced road system. Flood gates lie flat on the ground beneath the doors, to be raised only if necessary.

On the amphibious land, a new building would be made to be resilient to high waters. Where the wall does not touch buildings, it is set aside for pedestrian access over the wall.

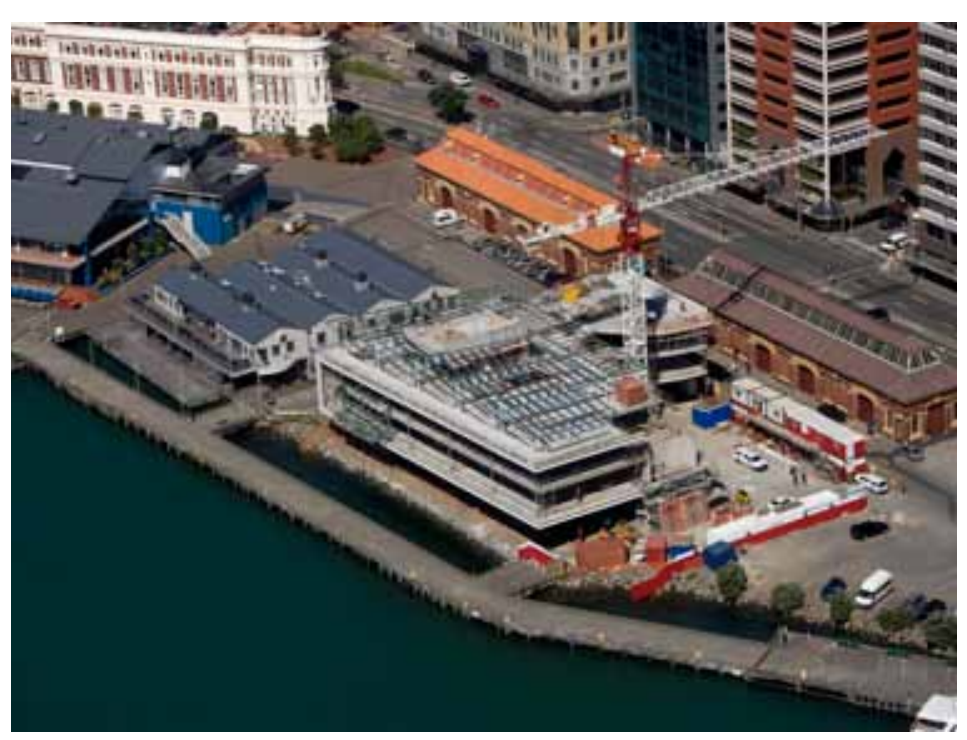

Fig 7.16 Aerial image: Kumutoto Precinct

(above) Image taken during construction of the Meridian

Energy Building and adjacent public spaces (November 2006)

Fig 7.18 Scematic overview (right)
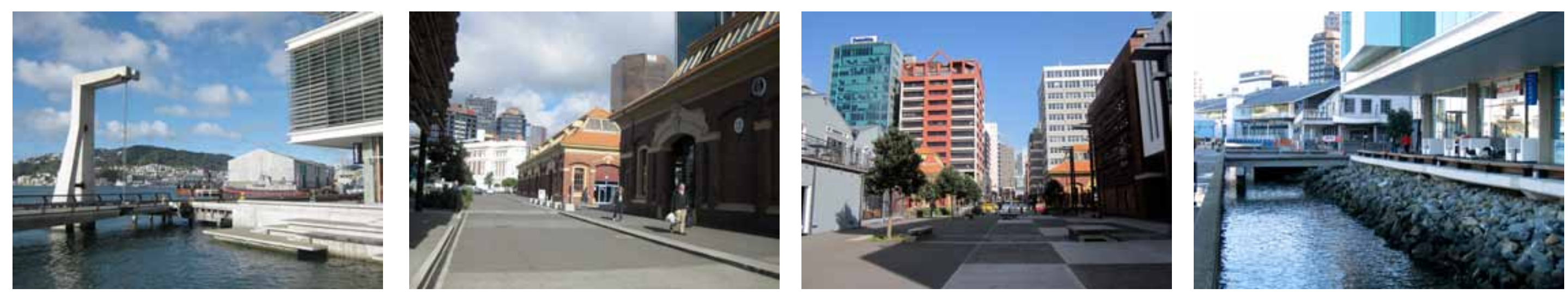


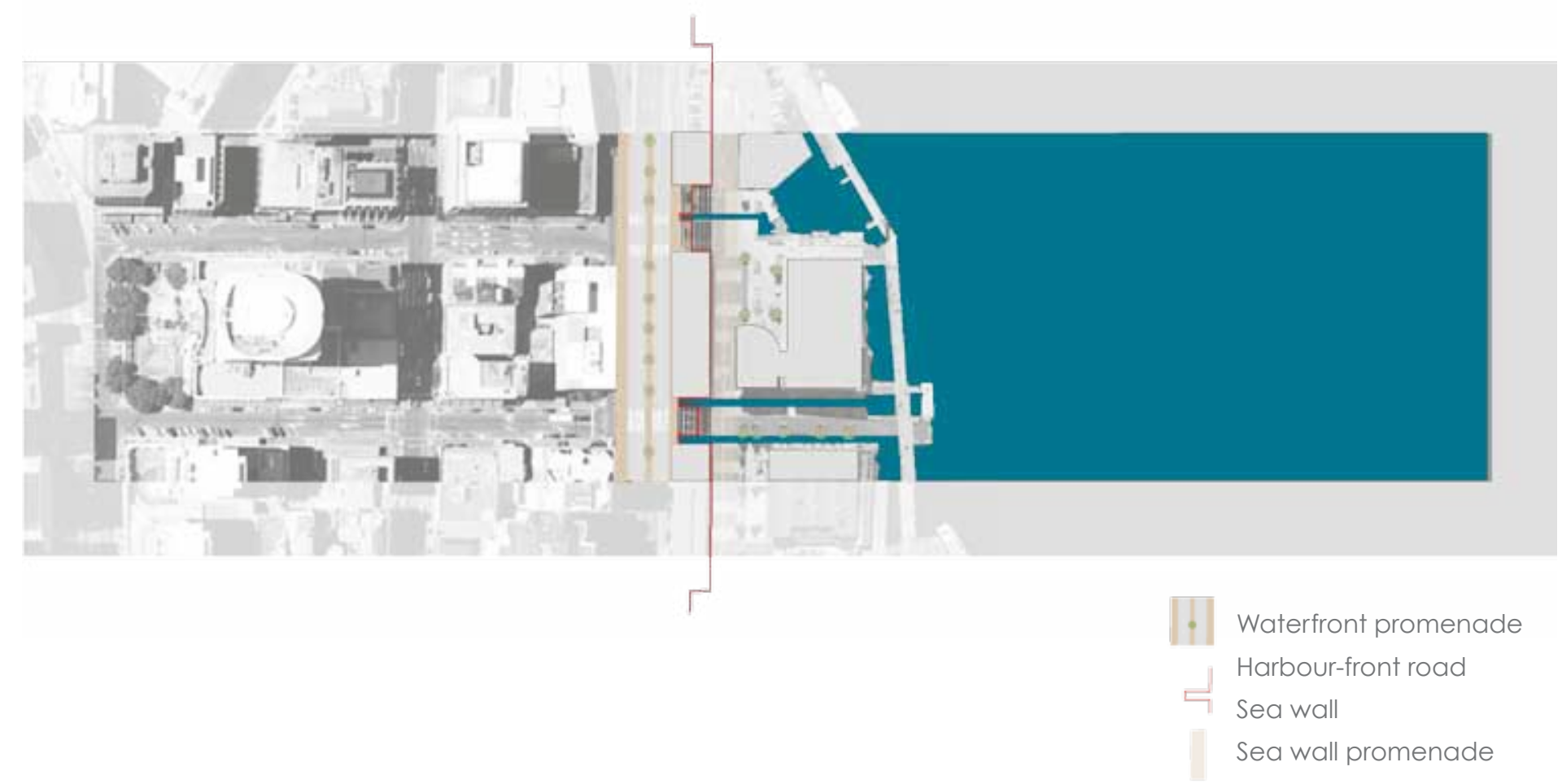

Land type

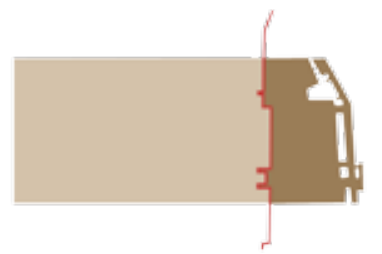

Flood sequence

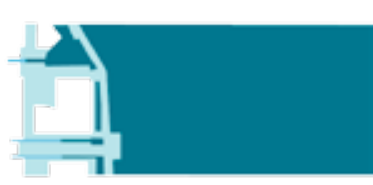

Low tide

High tide

Sea surge
Circulation

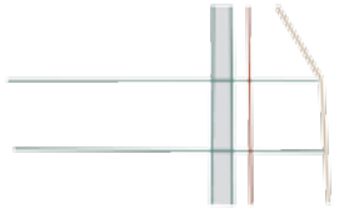

Water treatment

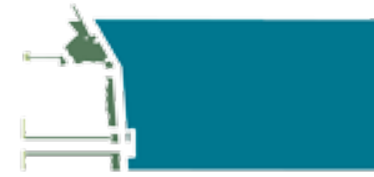

- Waterfront promenade

Harbour-front road

Man pedestiran route
Freshwater

- Saltwater

- sea 

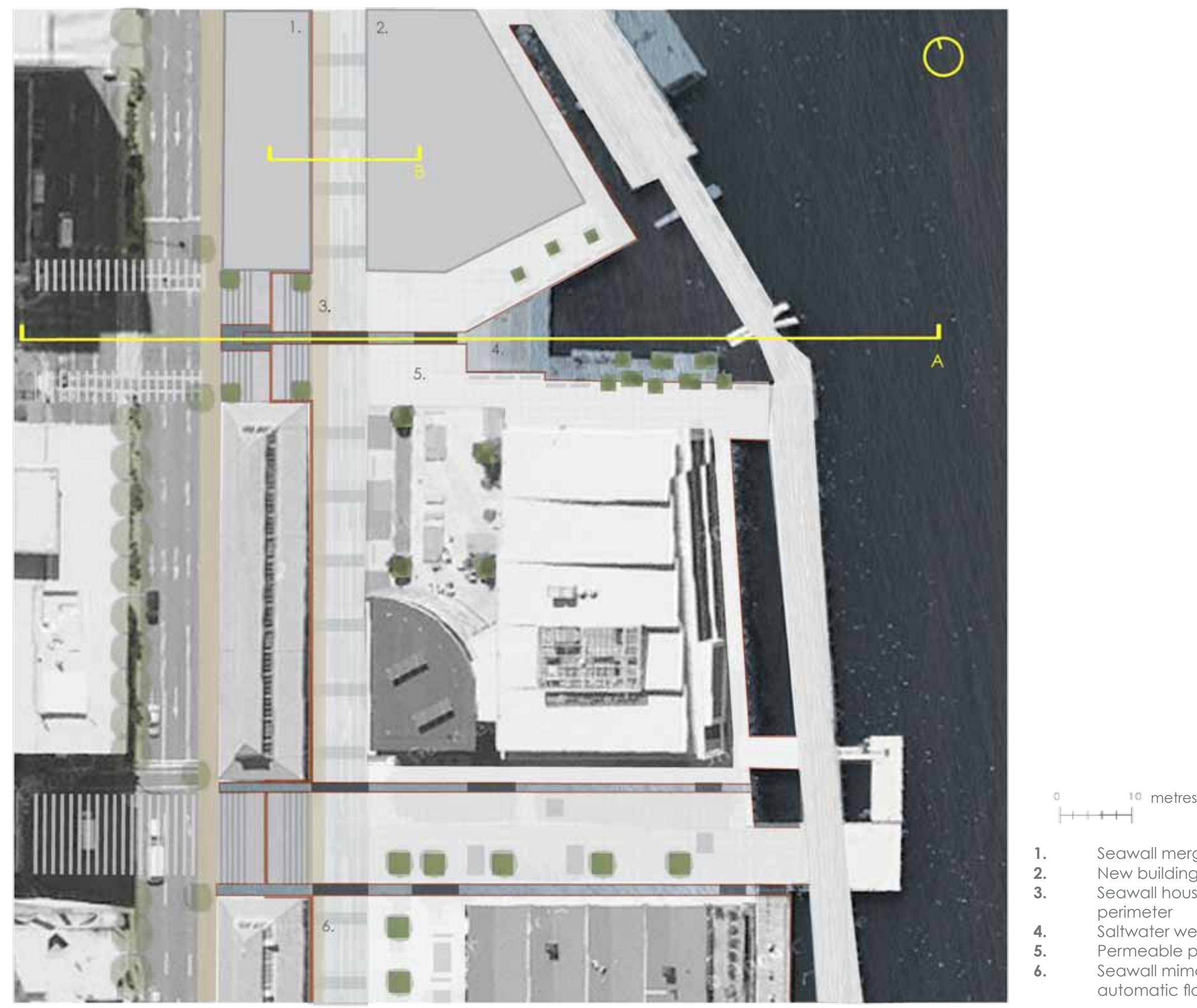

1. Seawall merged with new development

2. New building designed amphibious

Seawall houses stairs: Corten Steel Seawall hous
perimeter

Saltwater wetlands

Permeable paving

Seawall mimcs existing buildings +

automatic floodgate technology 

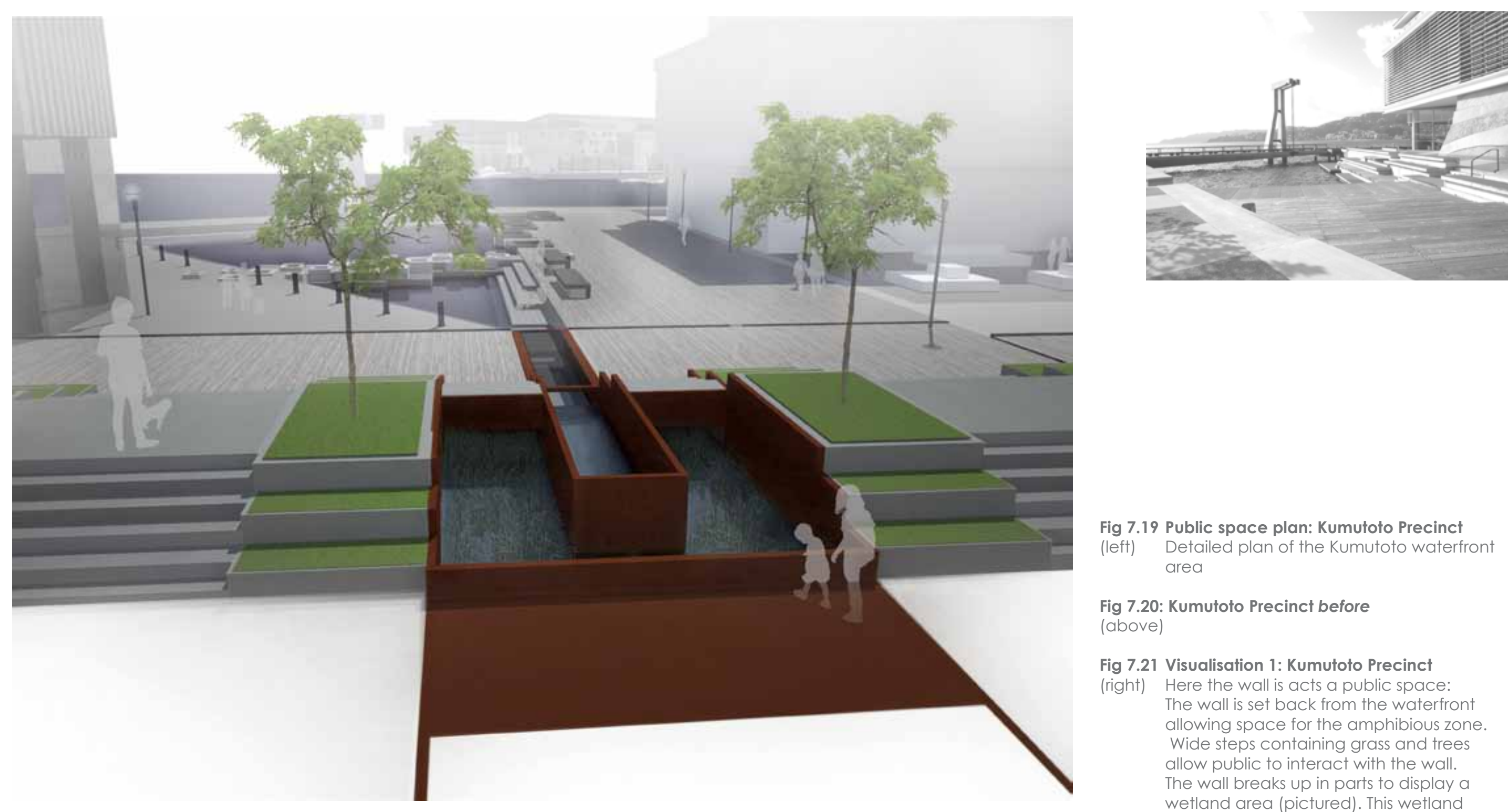

Fig 7.19 Public space plan: Kumutoto Precinct

(left) Detailed plan of the Kumutoto waterfront area

Fig 7.20: Kumutoto Precinct before (above)

Fig 7.21 Visualisation 1: Kumutoto Precinct (right) Here the wall is acts a public space: The wall is set back from the waterfront allowing space for the amphibious zone. Wide steps containing grass and trees allow public to interact with the wall. The wall breaks up in parts to display a wetland area (pictured). This wetland mixes salt and freshwater. It provides an opportunity for the public to note sea evel changes clearly. 


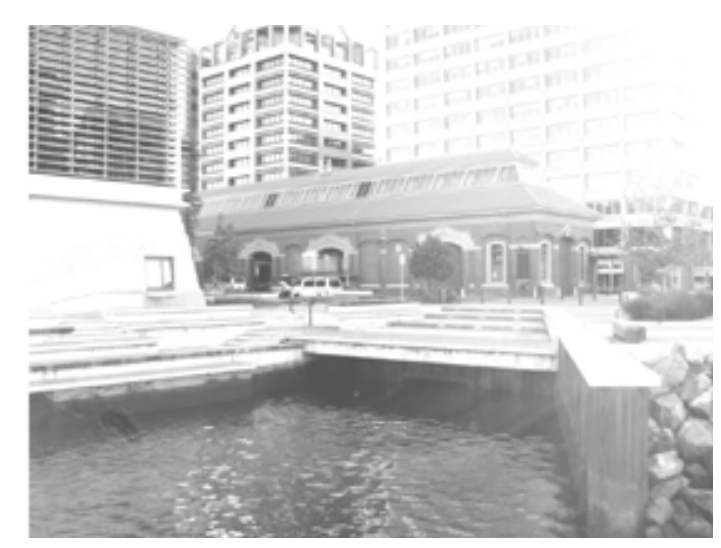

98

Fig 7.22: Kumutoto Precinct before

\section{(above)}

Fig 7.23 Visualisation 2: Kumutoto Precinct

(right) This area will become intertidal land thus has been set aside for wetland planting. The use of constructed wetlands as an ecological infrastructure addresses

several issues. The wetlands can provide

habitat to a diverse range of species. They

can provide visual interest, and act as bio-

filters, removing sediments from stormwater runoff before it enters the harbour.

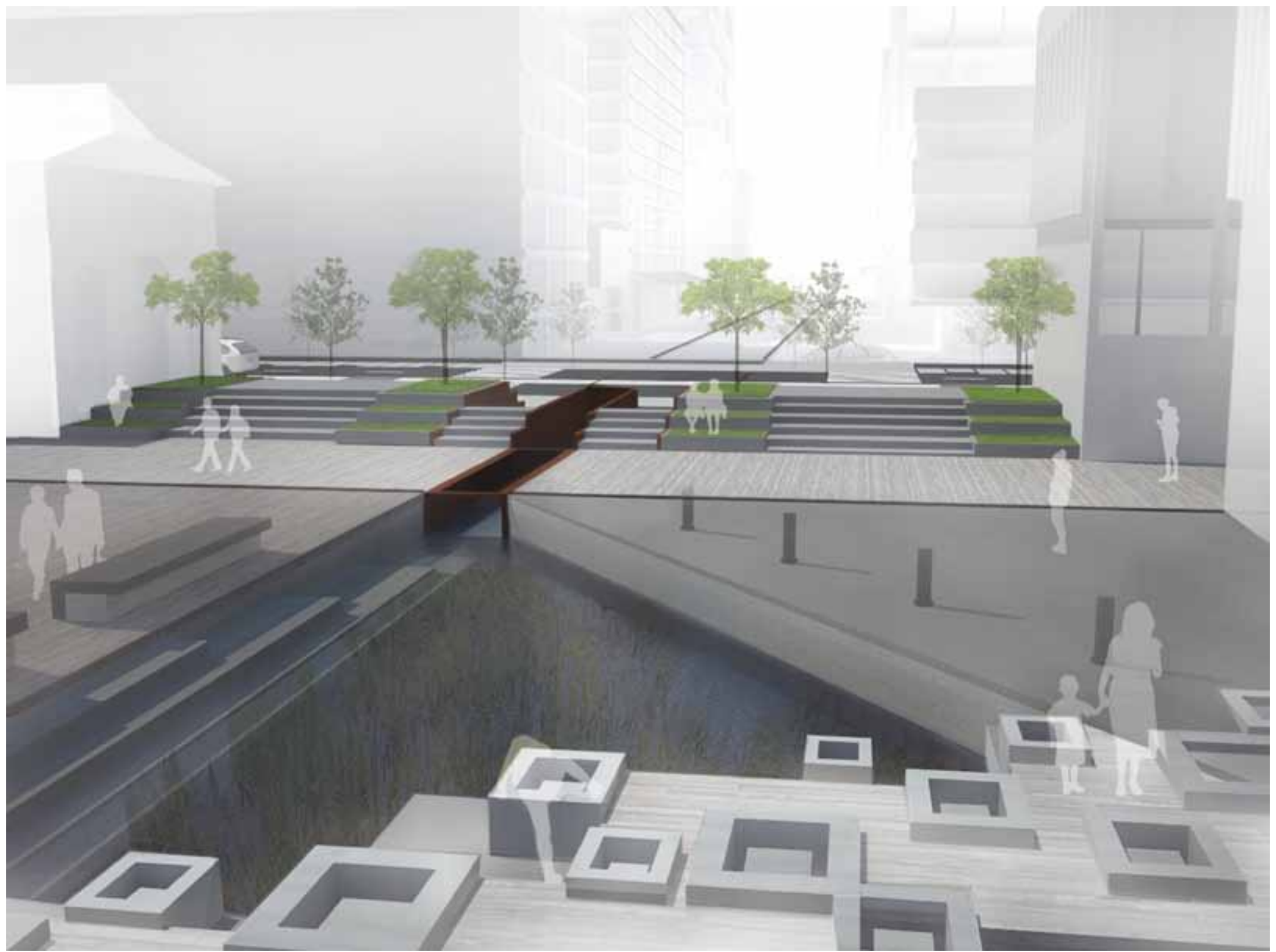



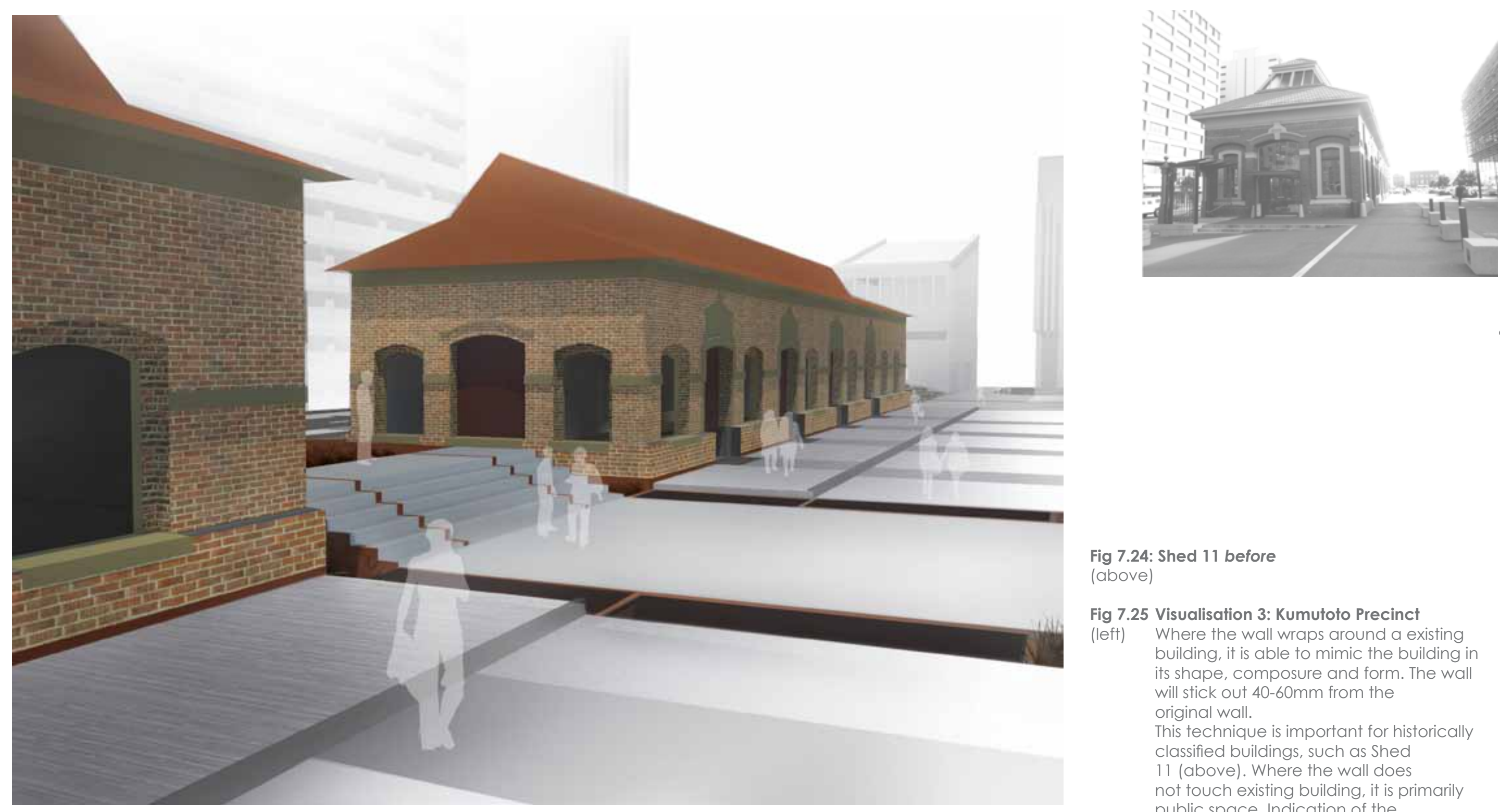

Fig 7.24: Shed 11 before

(above)

fig 7.25 Visualisation 3: Kumutoto Precinct

(left) Where the wall wraps around a existing building, it is able to mimic the building in its shape, composure and form. The wall will stick out 40-60mm from the original wall.

This technique is important for historically

classified buildings, such as Shed

11 (above). Where the wall does not touch existing building, it is primarily public space. Indication of the

wall's presence is made with a continuing line of Coreten steel. 
New building connected to wall Bulling designed alongside sea wall

Shared foundations with wall

Elevated access on seaward side

Floodgate technology on seaward side

Durable construction

Ground floor low vulnerability use

Possible 'amphibious' floating foundations

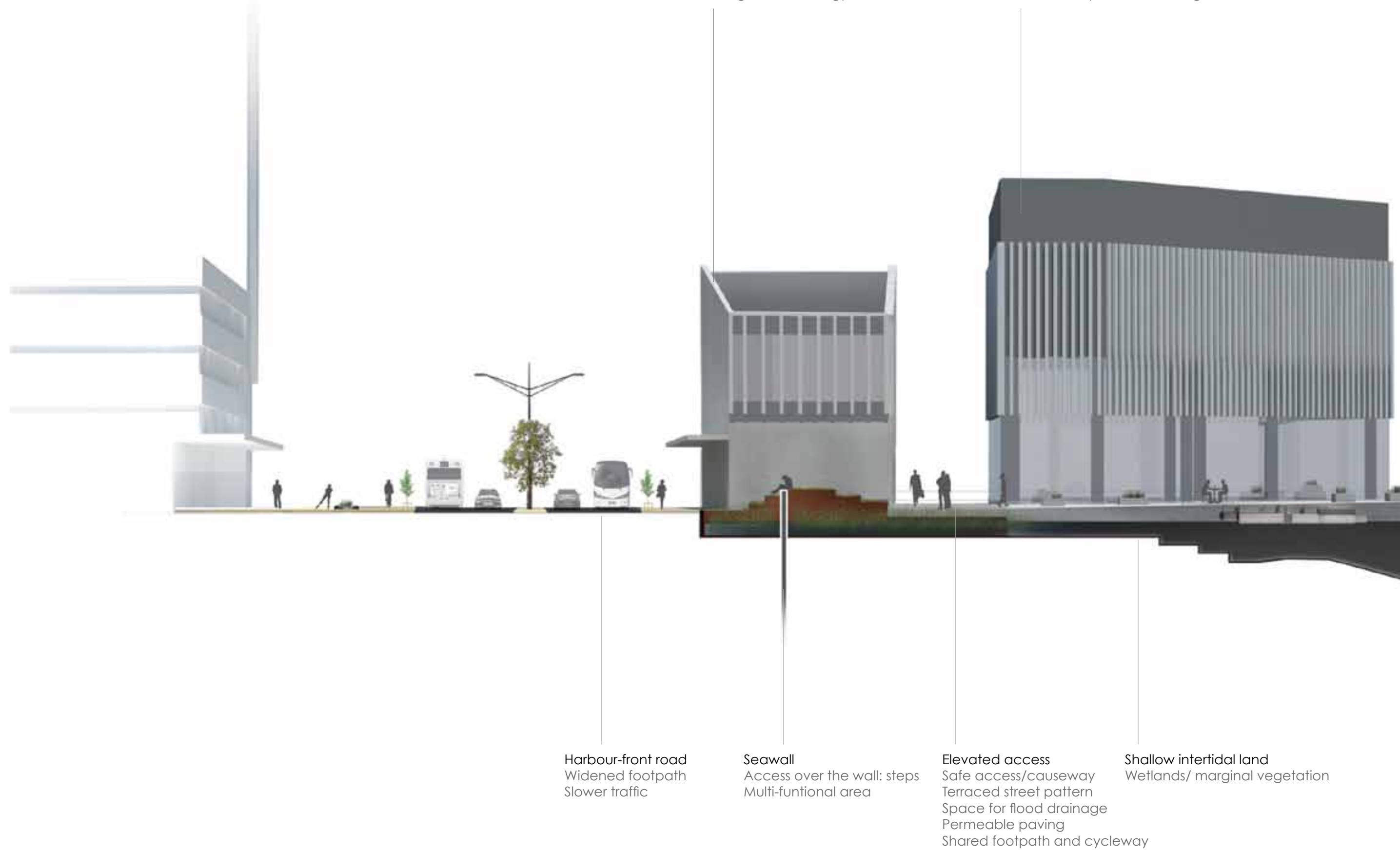




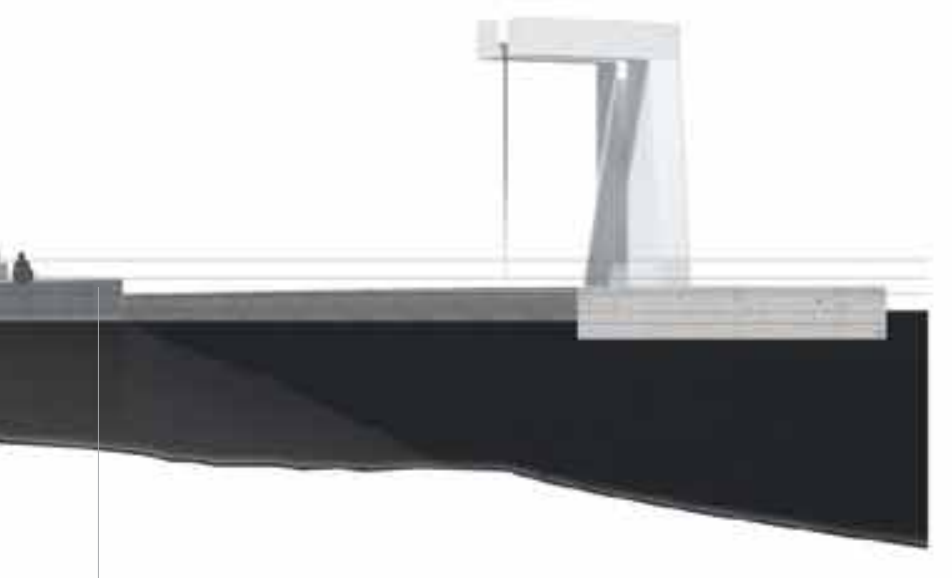

Built for floating foundations

Concrete salt-resistant frame

Durable consturction

Ground floor retail/cafes

Upper floors residential/office

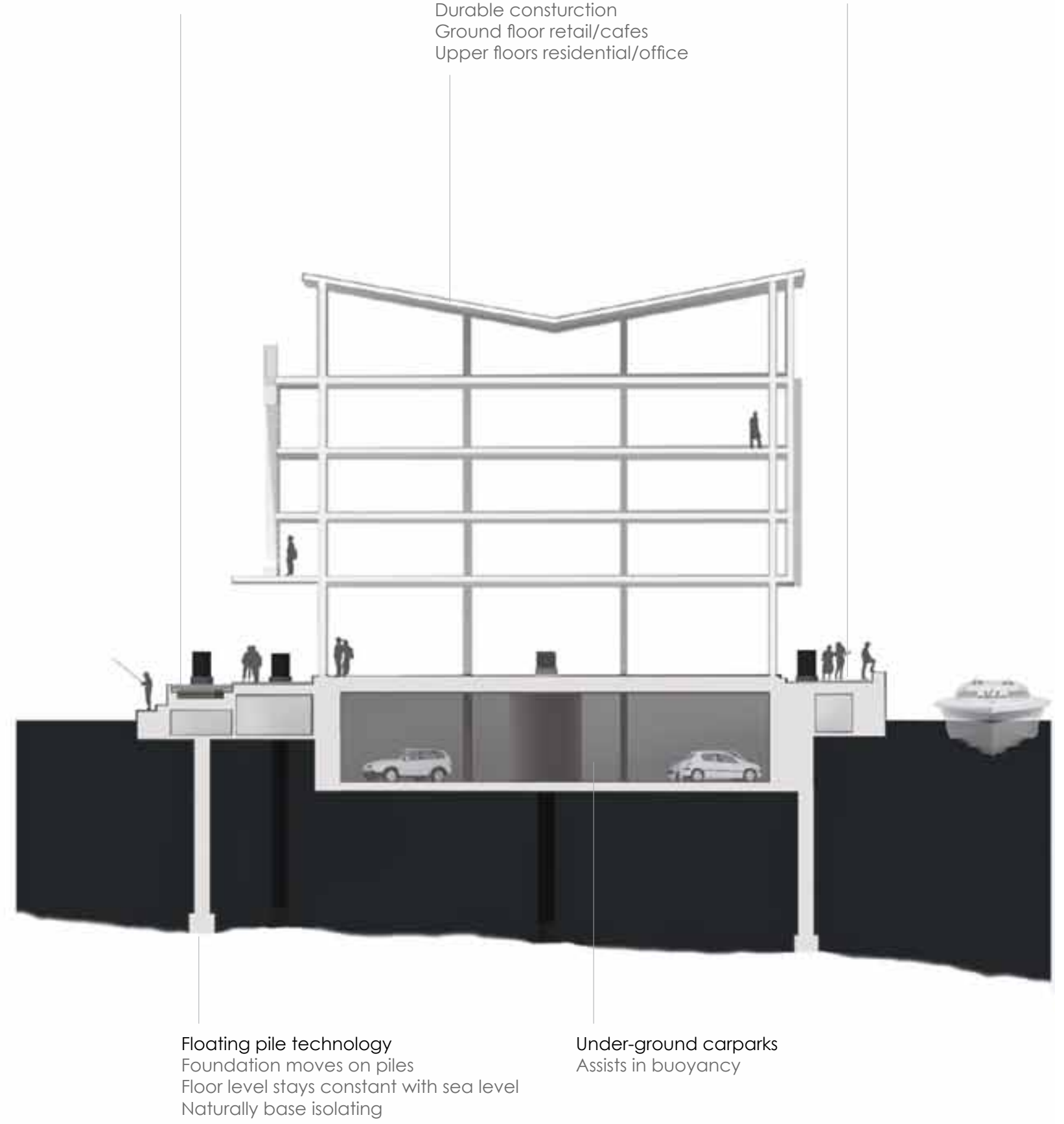

Public space

On all edges of building

Area for fishing, walking or boat access

.

Naturally base isolating 
Frank Kitts Park is the oldest of the three slices and lies on reclaimed land, which was once a wharf. The park was significantly extended in the late 1880s. It has spaces for a variety of recreational uses, and is often used for outdoor concerts and festivals.

Design options for Frank Kitts Park have been influenced by a design made for Wellington Waterfront Ltd. and Wellington Chinese Garden Society by Wraight + Associates with Athfield Architects.' An entire re-structuring of Frank Kitts Park has been proposed, with a new pavilion and Chinese garden. The design will retain space for events and the well-known children's playground. Plans were provided by Wellington Waterfront Ltd.

The proposed sea wall is largely hidden in the landscape of the park, which is already elevated above the wall's required height. Parts of the wall are exposed in a 'wall garden' to provide shelter and interesting scenes.

The waterfront promenade is retained, and a floating road is inserted into it.

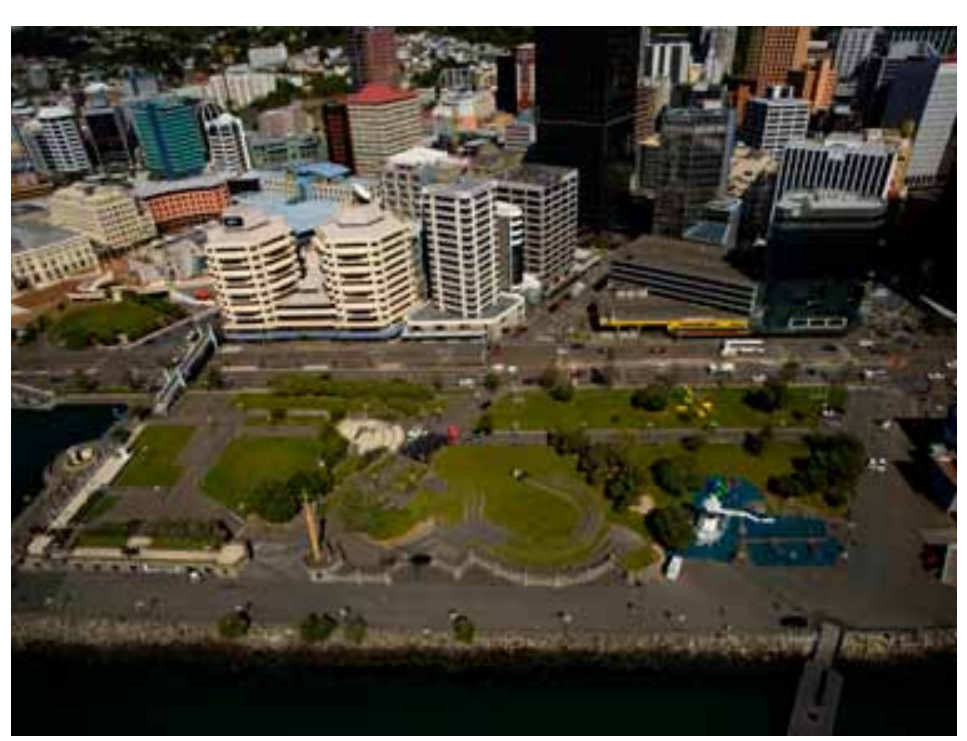

Fig 7.27 Aerial image: Frank Kitts Park

(above) (2006)

This was the winning design of a competition. (2007). Also produced by:

Duncan Campbell (Chinese Garden Consultant), Dunning Thornton (Structural), Connell Wagner (Civil, Services) and SKM (Lighting).

http://www.wellingtonwaterfront.co.nz/media section/ News releases/new releases_bg/frank_kitts_park_design competition.htm

Fig 7.29 Scematic overview (right)
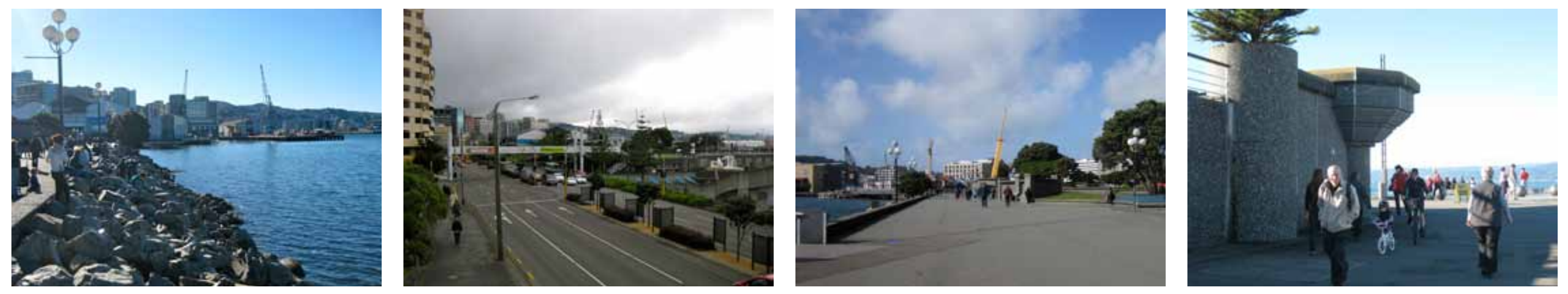

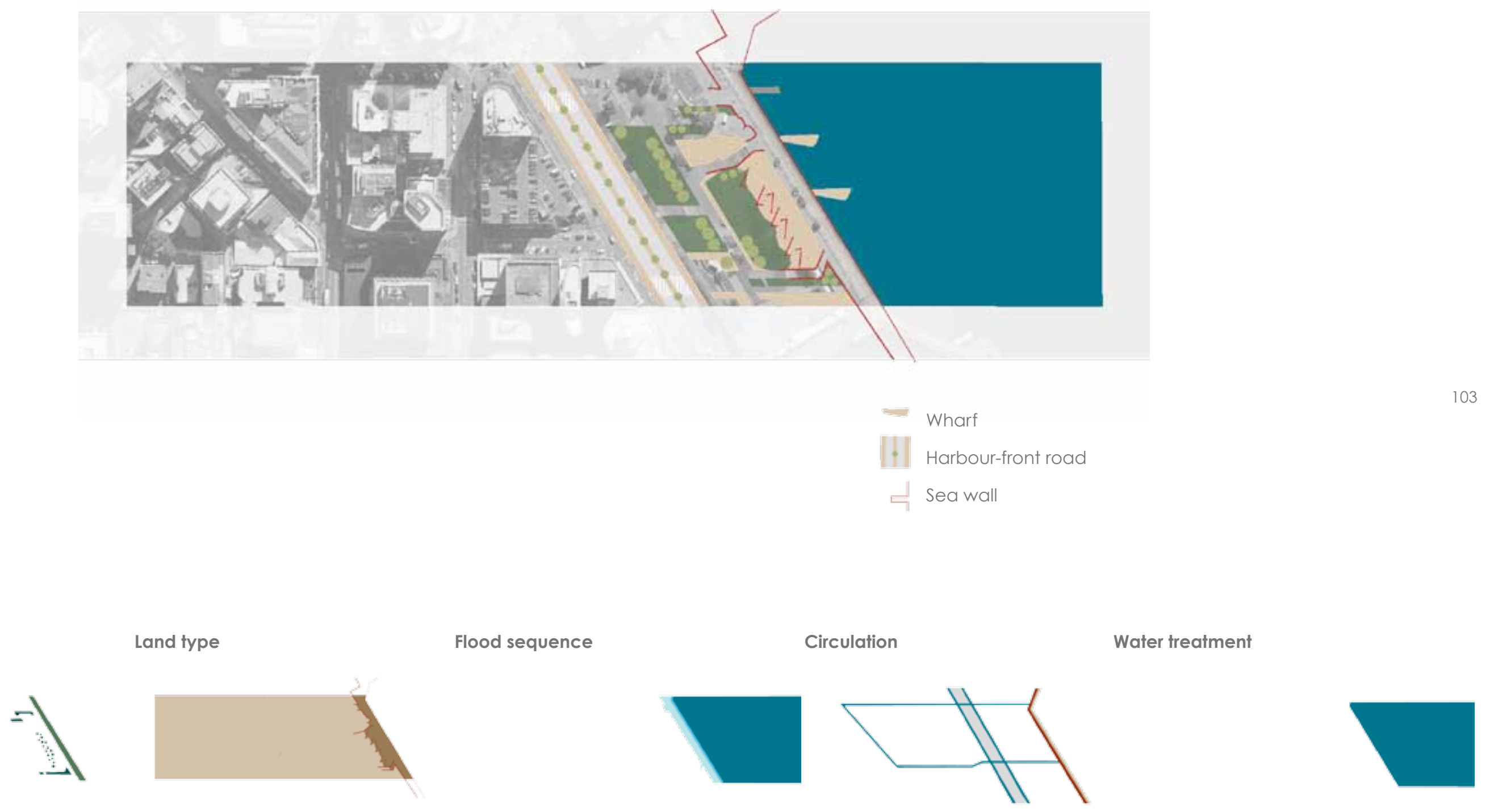

$\begin{array}{ll}\text { Saltwater wetland } & \text { Exposed } \\ \text { Saline tolerant planting } & \text { Protected } \\ & \text { Sea wall }\end{array}$

Low tide

High tide

Sea surge
Waterfront promenade
Harbour-front road
Man pedestiran route
- Sea wall promenade



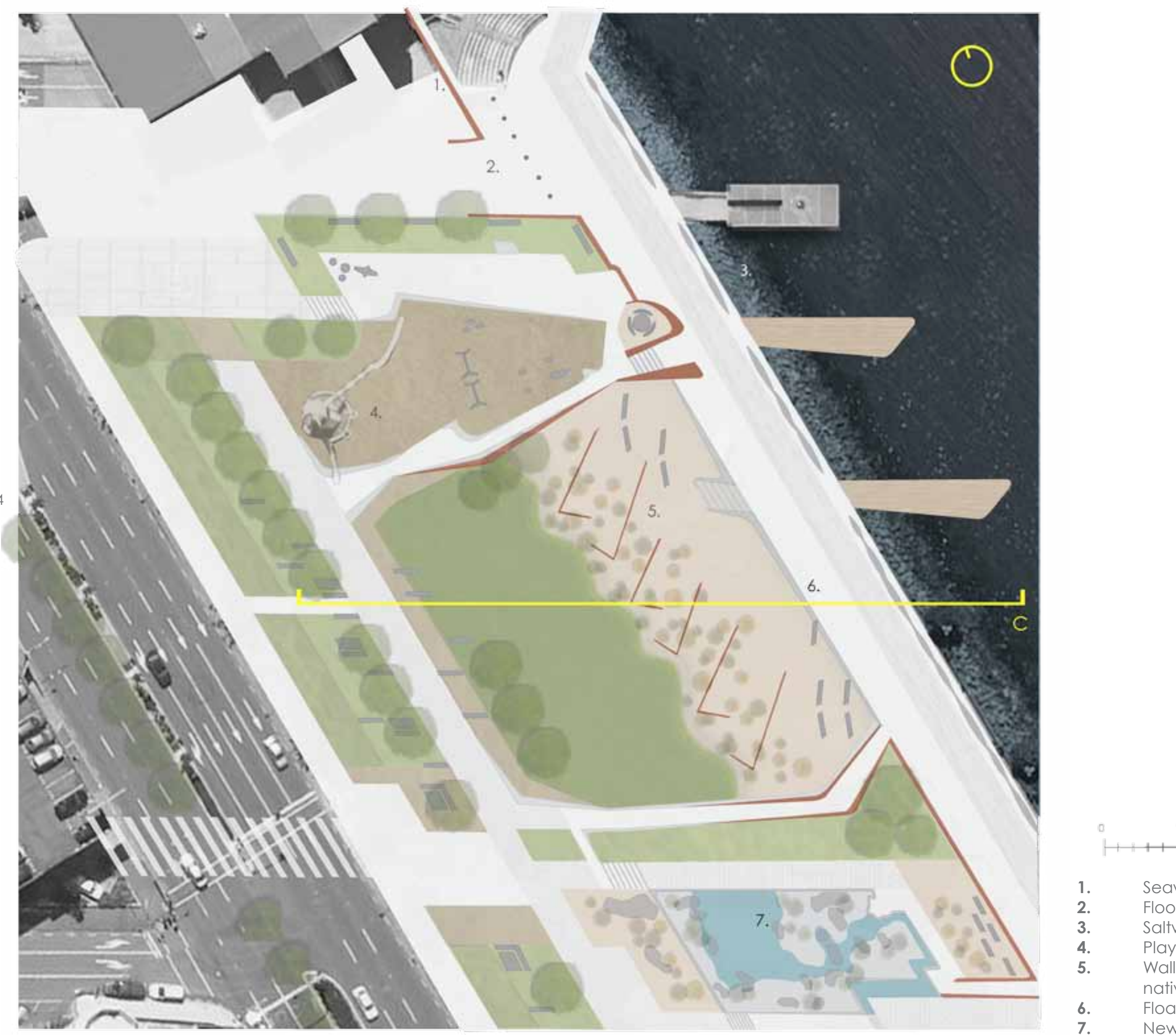

metres

Seawall mimics existing building Floodgate, open at most times Saltwater wetlands

Playground relocated

Wall garden amongst saline-tolerant native plants 

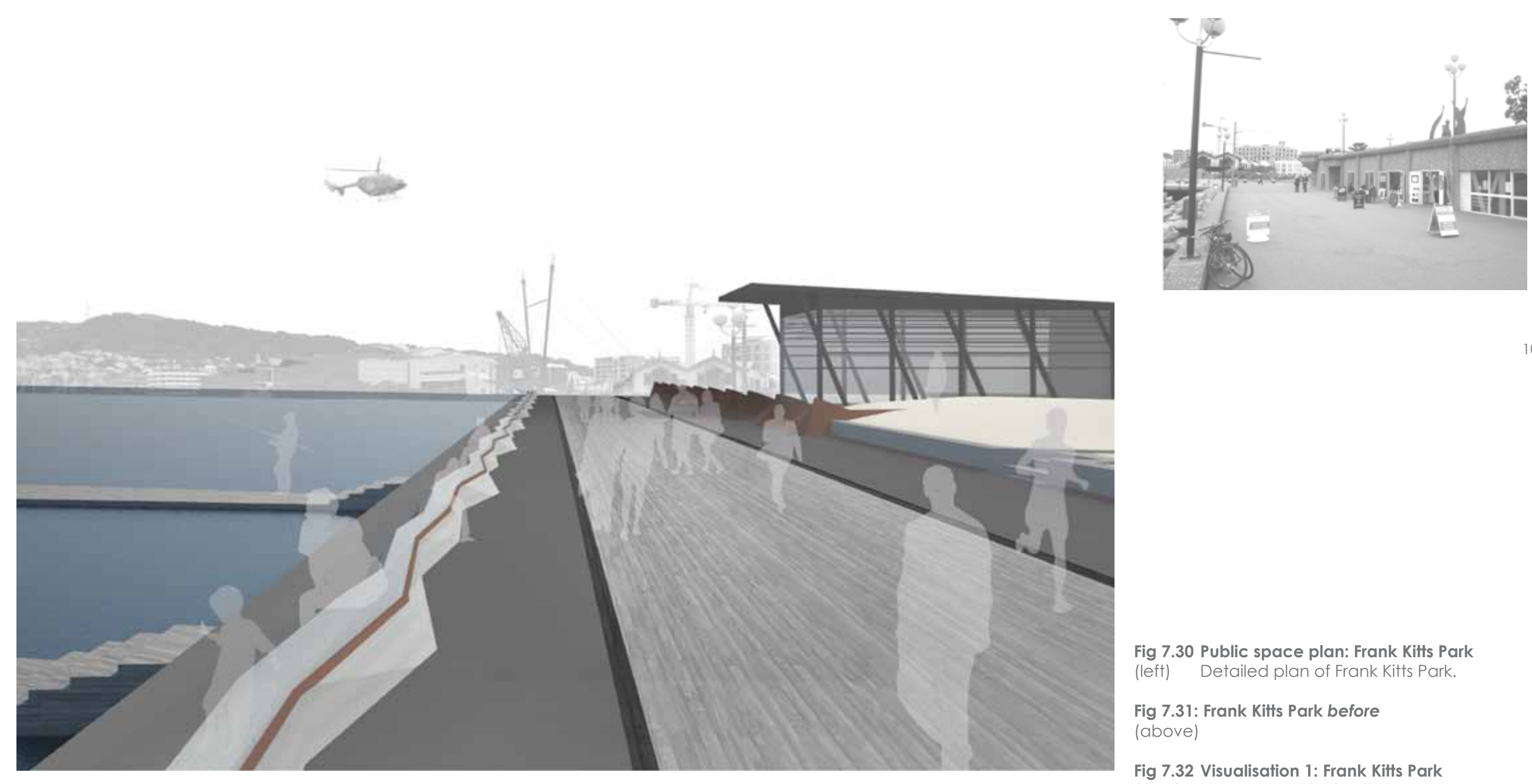

Fig 7.30 Public space plan: Frank Kitts Park (left) Detailed plan of Frank Kitts Park.

Fig 7.31: Frank Kitts Park before (above)

Fig 7.32 Visualisation 1: Frank Kitts Park (right) Here the wall is hidden in the rock garden on the left. A floating walkway has been inserted into the ground. Staged protection is provided for by the smaller sea wall on the left. 
Harbour-front road

Footpath shared by bicycle + pedestrian

Slower traffic

Saline tolerant native planting$$
\text { Pohutakawa }
$$

Karaka

Taupata

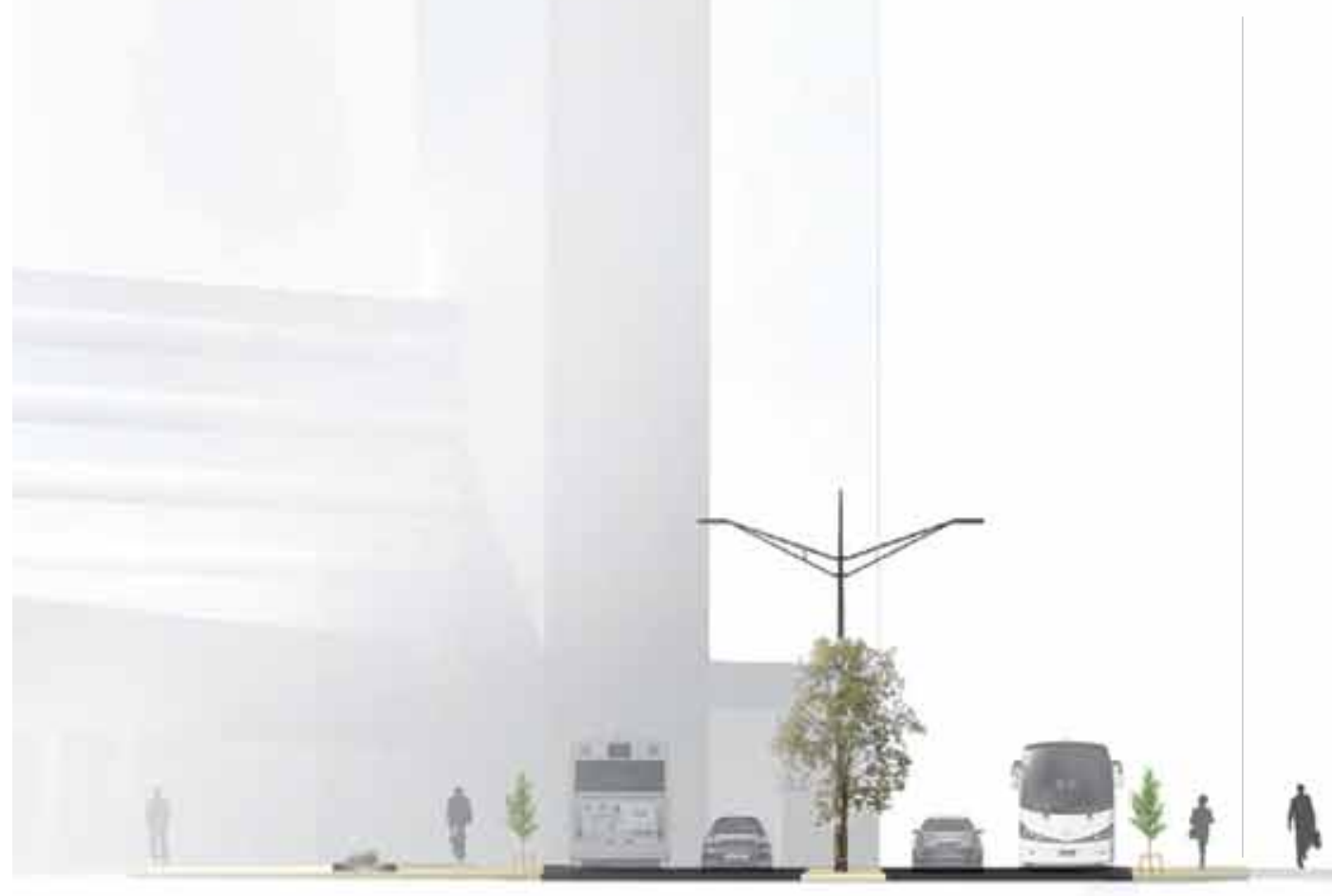




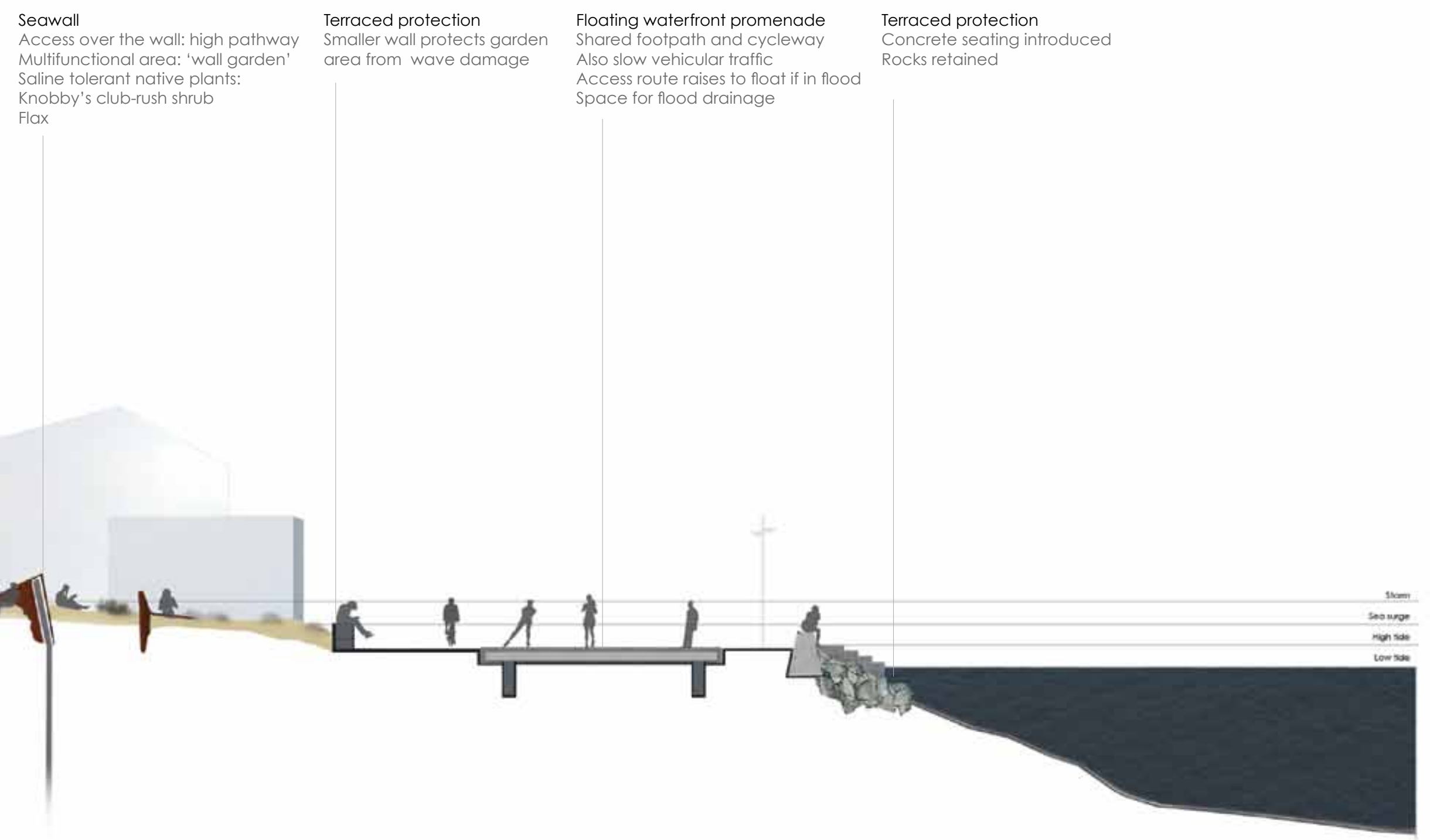




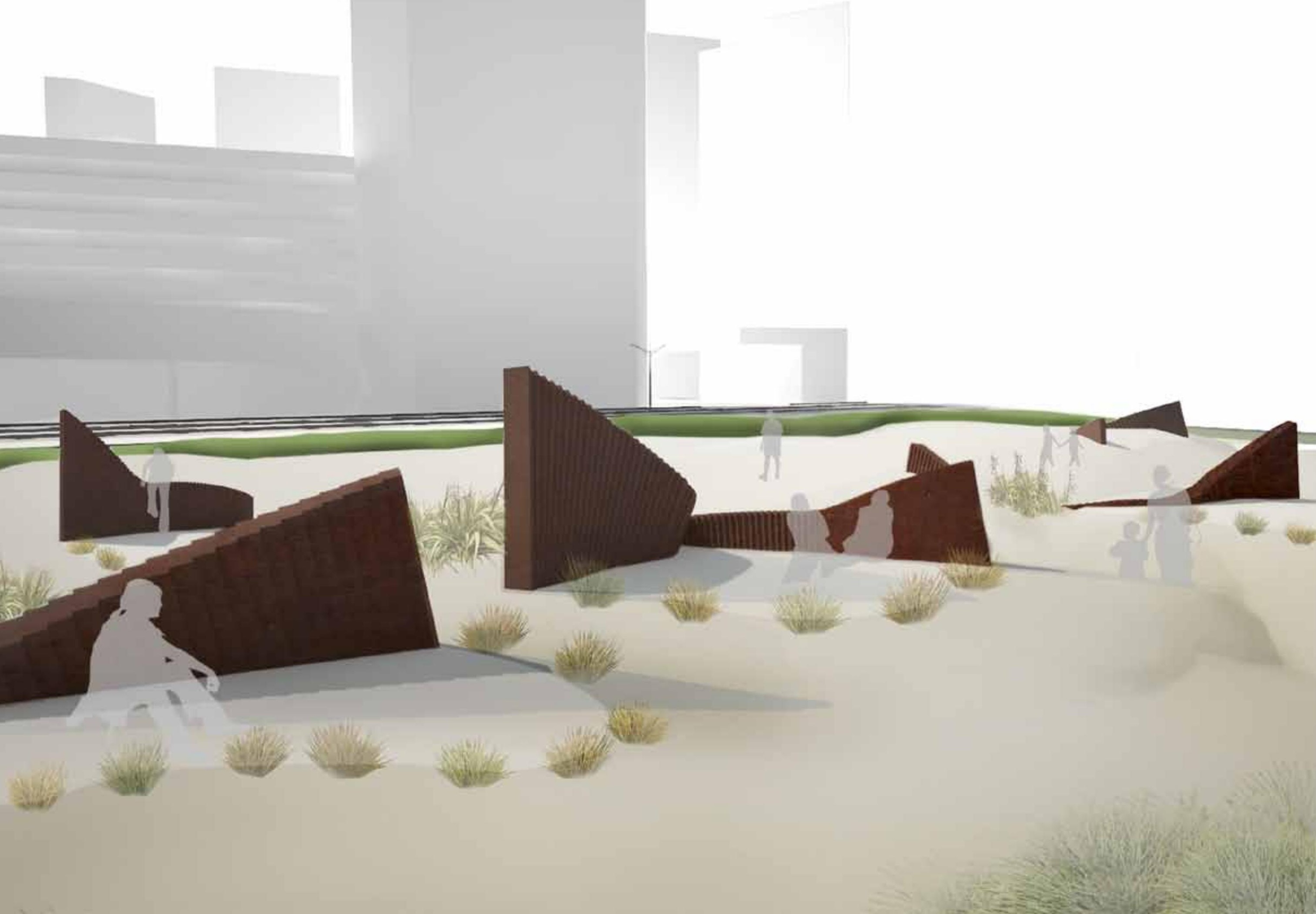




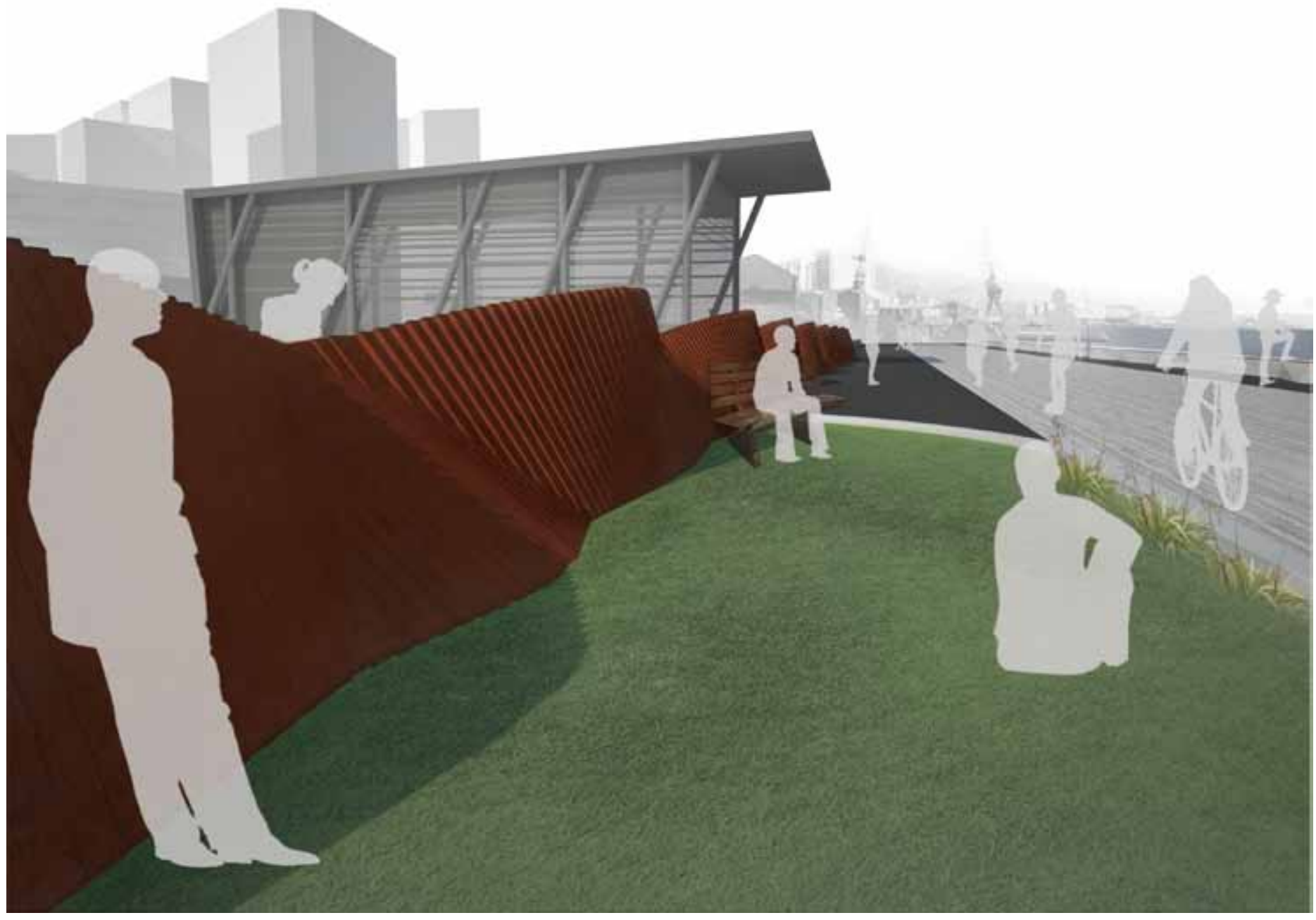

Fig 7.34 Visualisation 2: Frank Kitts Park

(left) 'Wall garden': Wall is exposed only in parts to become part of a garden and provide shelter/ shade
Fig 7.35 Visualisation 2: Frank Kitts Park

above) Wall is exposed and made higher in this area to provide shelter to Chinese Garden on the other side 
Waitangi Park is the largest of Wellington's new waterfront developments. Seventy-five percent of the original design has now been completed.' The design incorporates a new building on the west of the park which has been proposed by Wellington Waterfront Ltd.

Waitangi Park is also entirely reclaimed land. It incorporates the Waitangi Steam, which used to feed into a lagoon. ${ }^{2}$

The concept of estuary has been developed for the proposed design: an estuary being a semienclosed coastal body of water with one or rivers flowing into it. Waitangi Park's original freshwater wetland nature has been preserved; however intertidal salt-water wetlands have also been introduced. The Waitangi Stream is exposed to saltwater wetlands on the landward side of the wall and freshwater wetlands on the seaward side of the wall, before being expelled into the harbour.

In Waitangi Park, the sea wall acts primarily as a public walkway. Land treatment on each side of the wall is entirely different, providing for interesting views.

Amphibious land is primarily public space, and contains native coastal plants and wetland species.

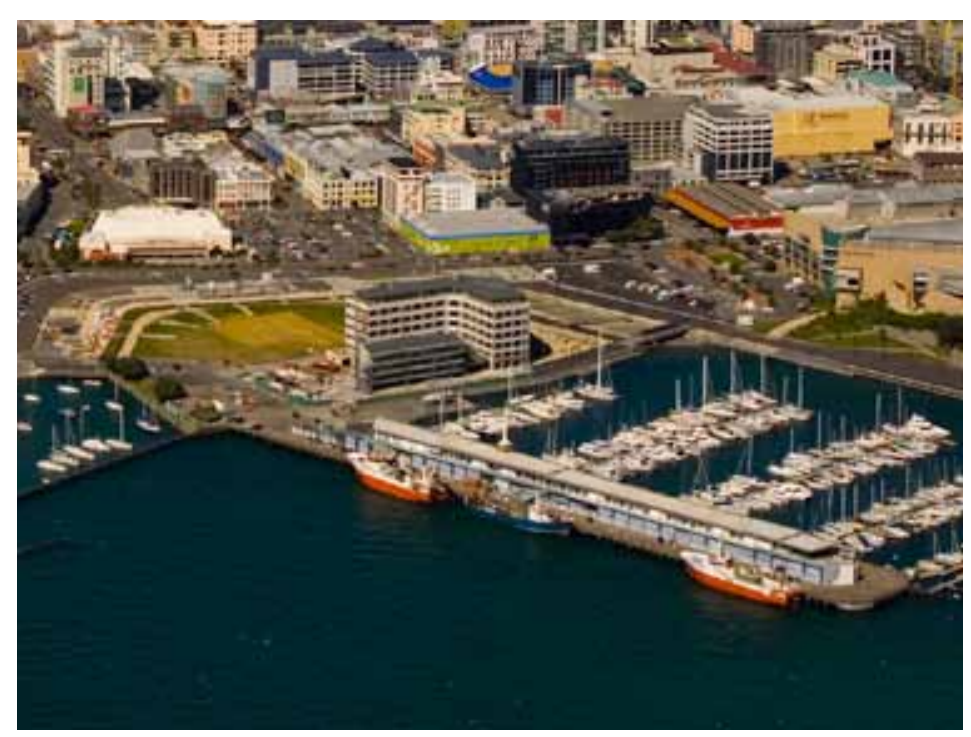

Fig 7.36 Aerial image: Waitangi Park

(above) (2006)

1 http://www.wellingtonwaterfront.co.nz/development/ waitangi/waitangi_park_introduction/

2 http://www.wellingtonwaterfront.co.nz/development/ waitangi/waitangi_park_introduction/brief_history_of_the area/index.htm

Fig 7.38 Scematic overview (right)
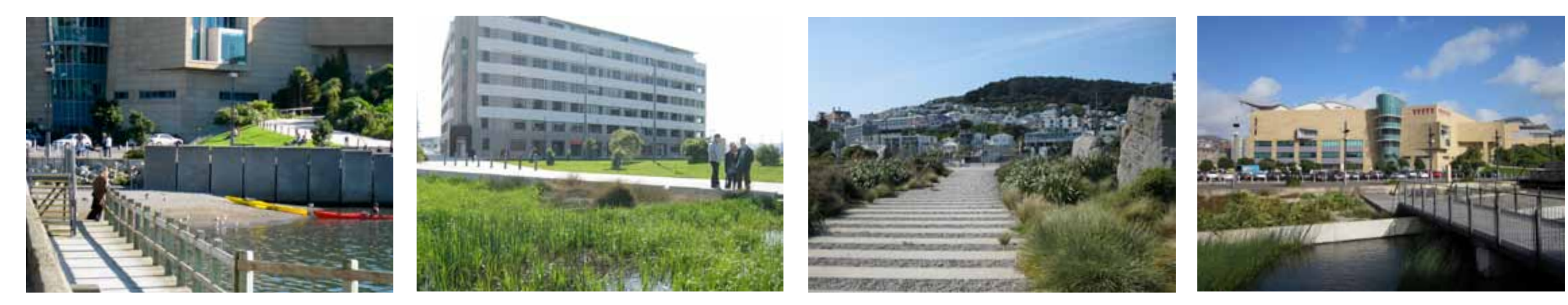


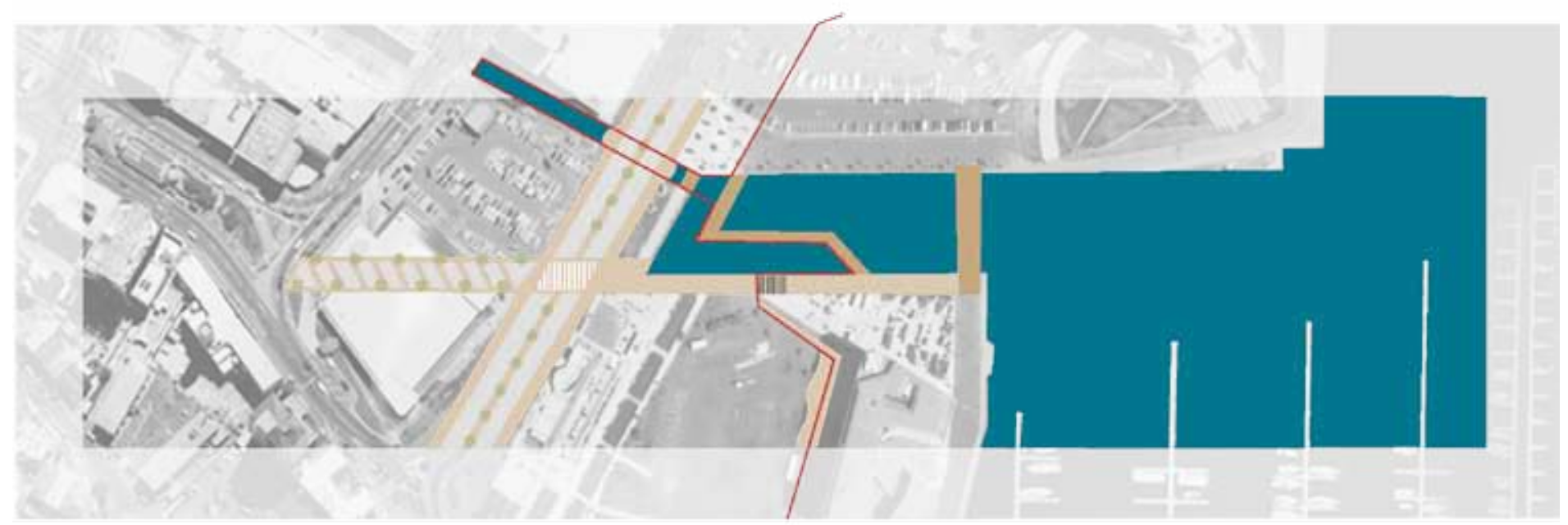

Bridge

[. Harbour-front road

- Seawall
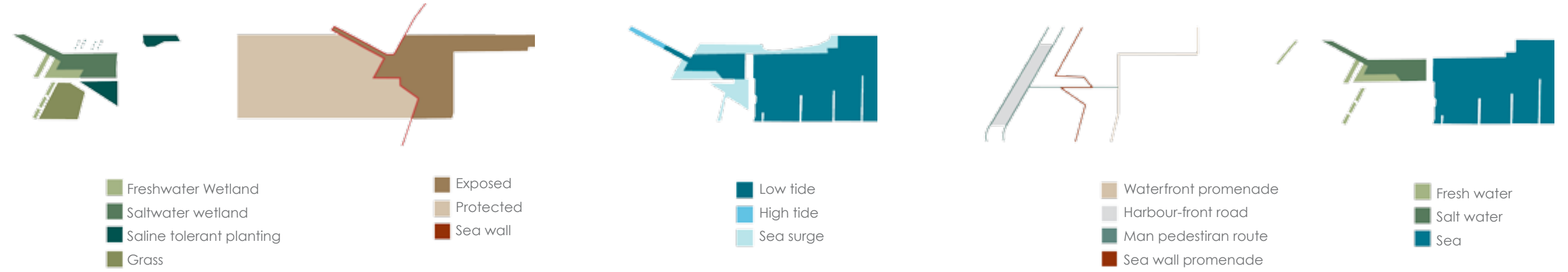
Low tide
High tide
Sea surge
Waterfront promenade
Harbour-front road
- Man pedestiran route
- Sea wall promenade

$\square$ Fresh water
Salt water
Sea 


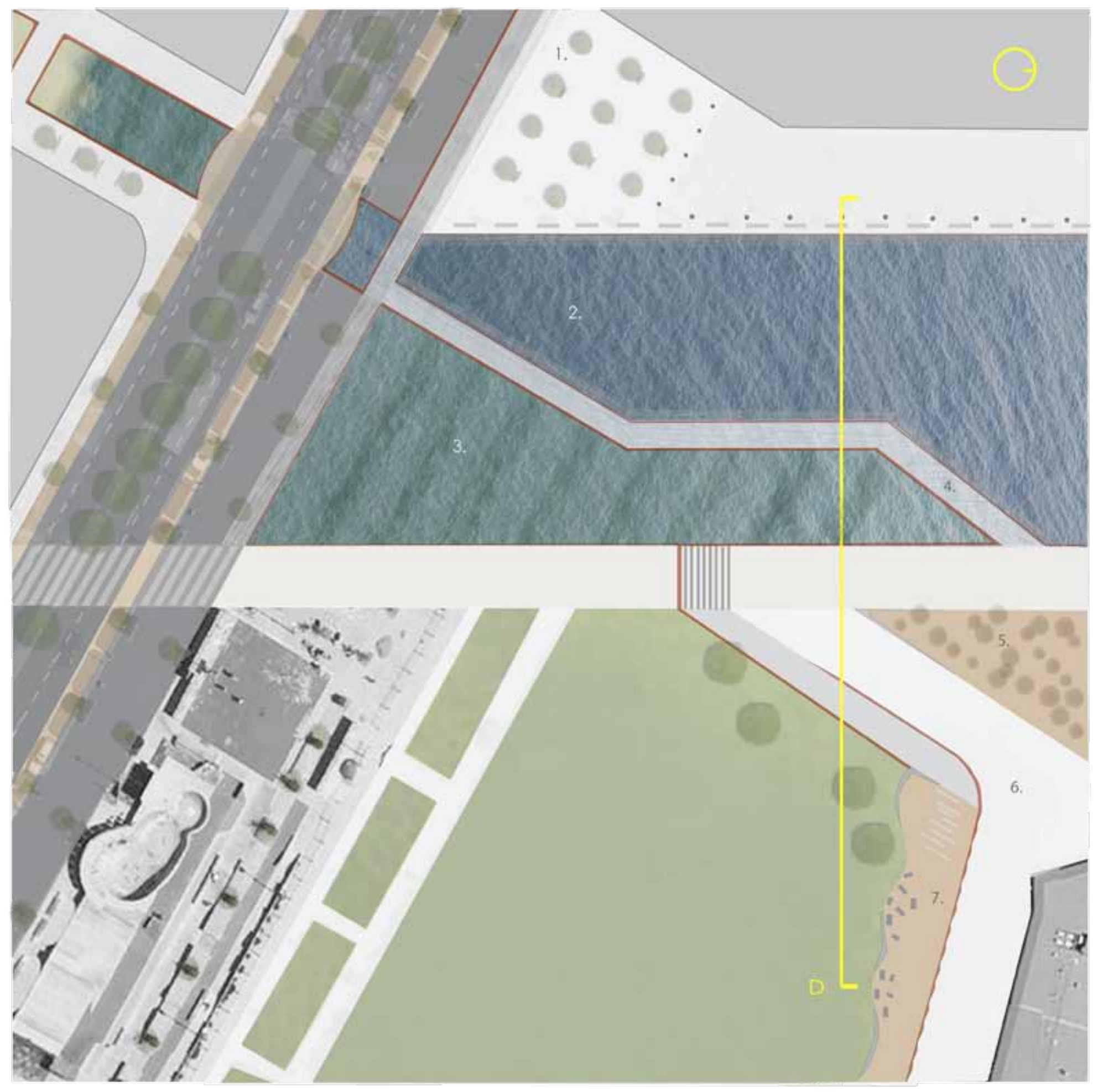

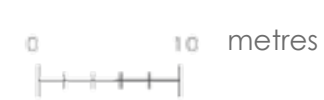

Saline tolerant raingardens

Saltwater wetlands

Freshwater wetlands

Exposed steel sheet piling

Saline-tolerant native planting

Permeable paving

Seawall promenade 

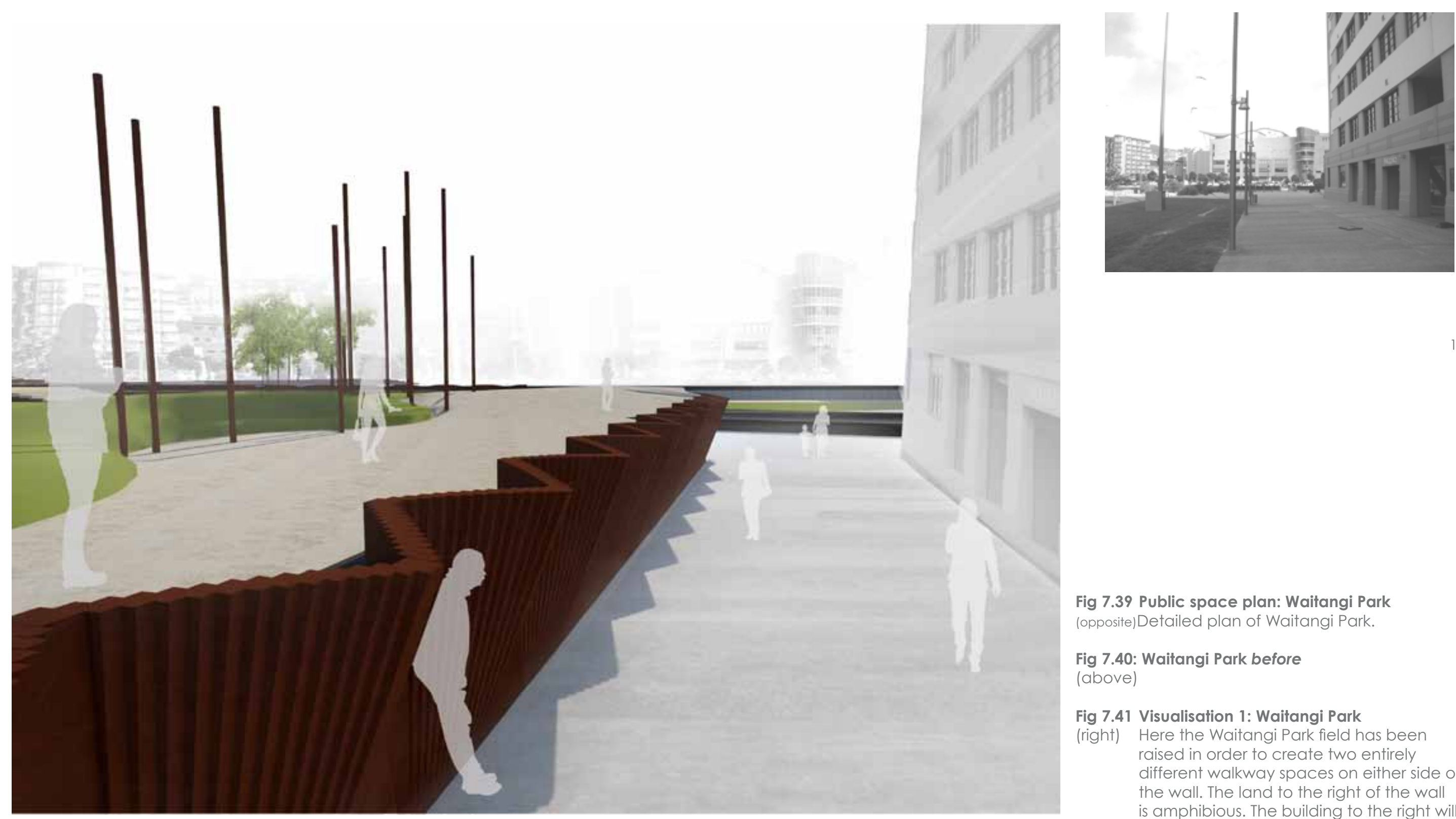

Fig 7.39 Public space plan: Waitangi Park opposite)Detailed plan of Waitangi Park.

Fig 7.40: Waitangi Park before above)

Fig 7.41 Visualisation 1: Waitangi Park

(right) Here the Waitangi Park field has been raised in order to create two entirely different walkway spaces on either side of the wall. The land to the right of the wall is amphibious. The building to the right will have to be retrofitted to adapt to periodic seawater inundation. 
Te Papa

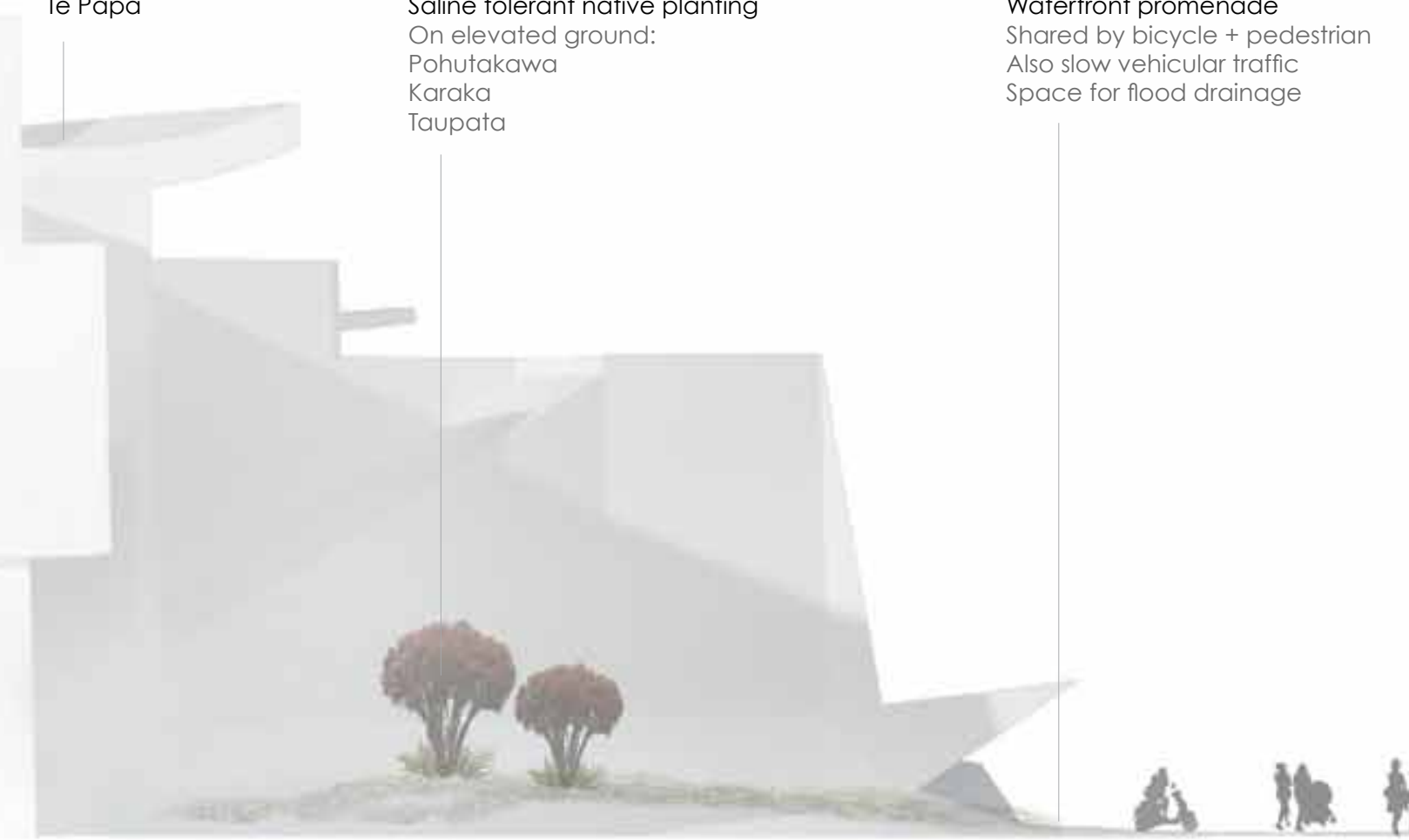

Saltwater wetlands

Inter-tidal habita
Seawall

Wall as walkway 
Freshwater wetlands

Shallow water

Cleanses water from Waitangi Stream

\section{Waterfront promenade}

Shared footpath and cycleway

Also slow vehicular traffic

space for flood drainage
Seawal

Access over the wall: ramp

Wall as walkway

Saline tolerant native planting

Pohutakawa

Karaka

Taupata
Waitangi Field

(

Steel poles added for visual interest

\section{Raingarden}

Saline tolerant native plants:

Knobby's club-rush shrub

Flax 

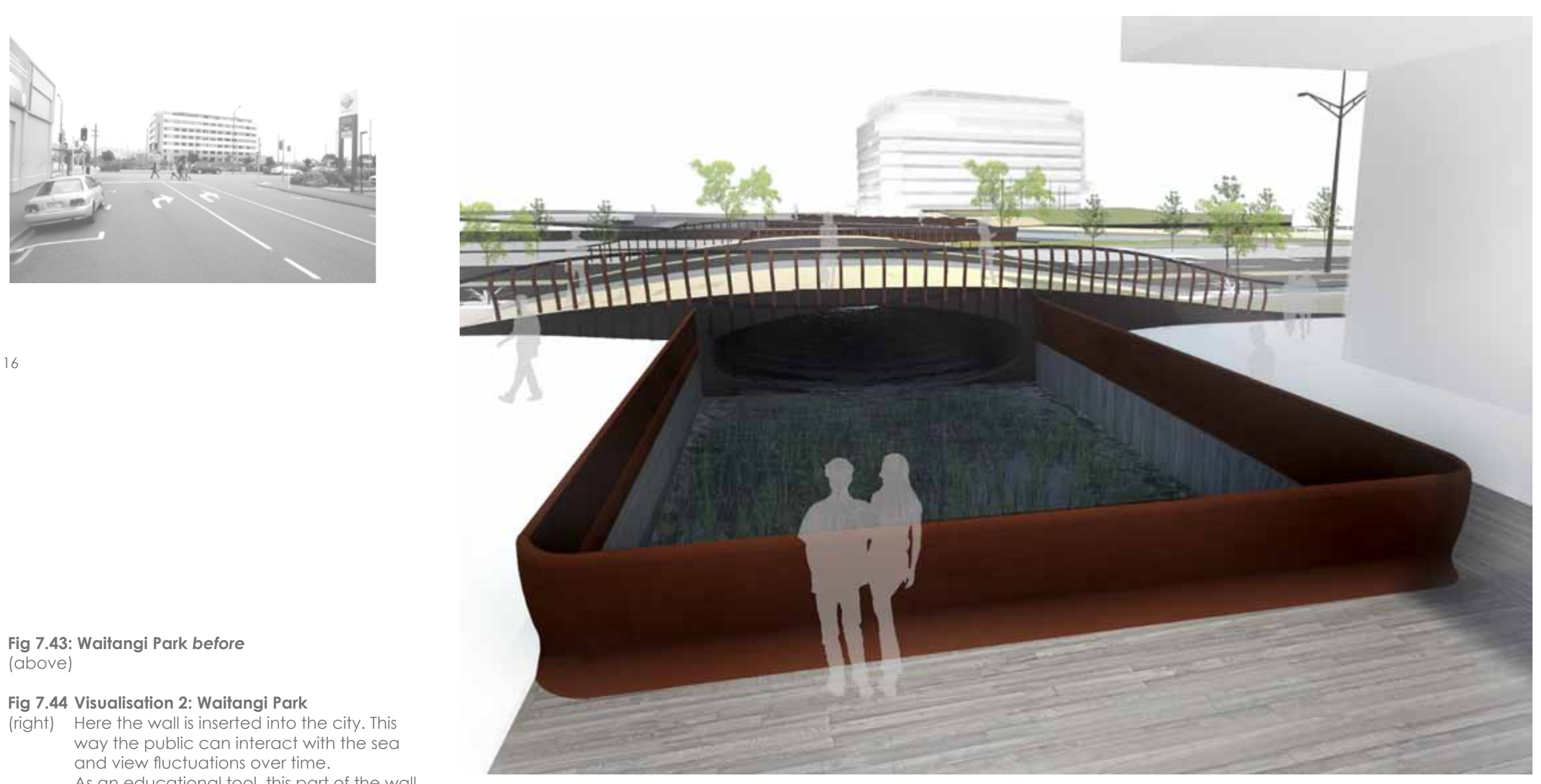

Fig 7.43: Waitangi Park before (above)

Fig 7.44 Visualisation 2: Waitangi Park

(right) Here the wall is inserted into the city. This way the public can interact with the sea and view fluctuations over time.

As an educational tool, this part of the wall

can record rises in sea level over

long stretches of time by the changes in

intertidal habitat which changes as the

average daily level of the sea changes.

This image is of a high sea surge situation. 

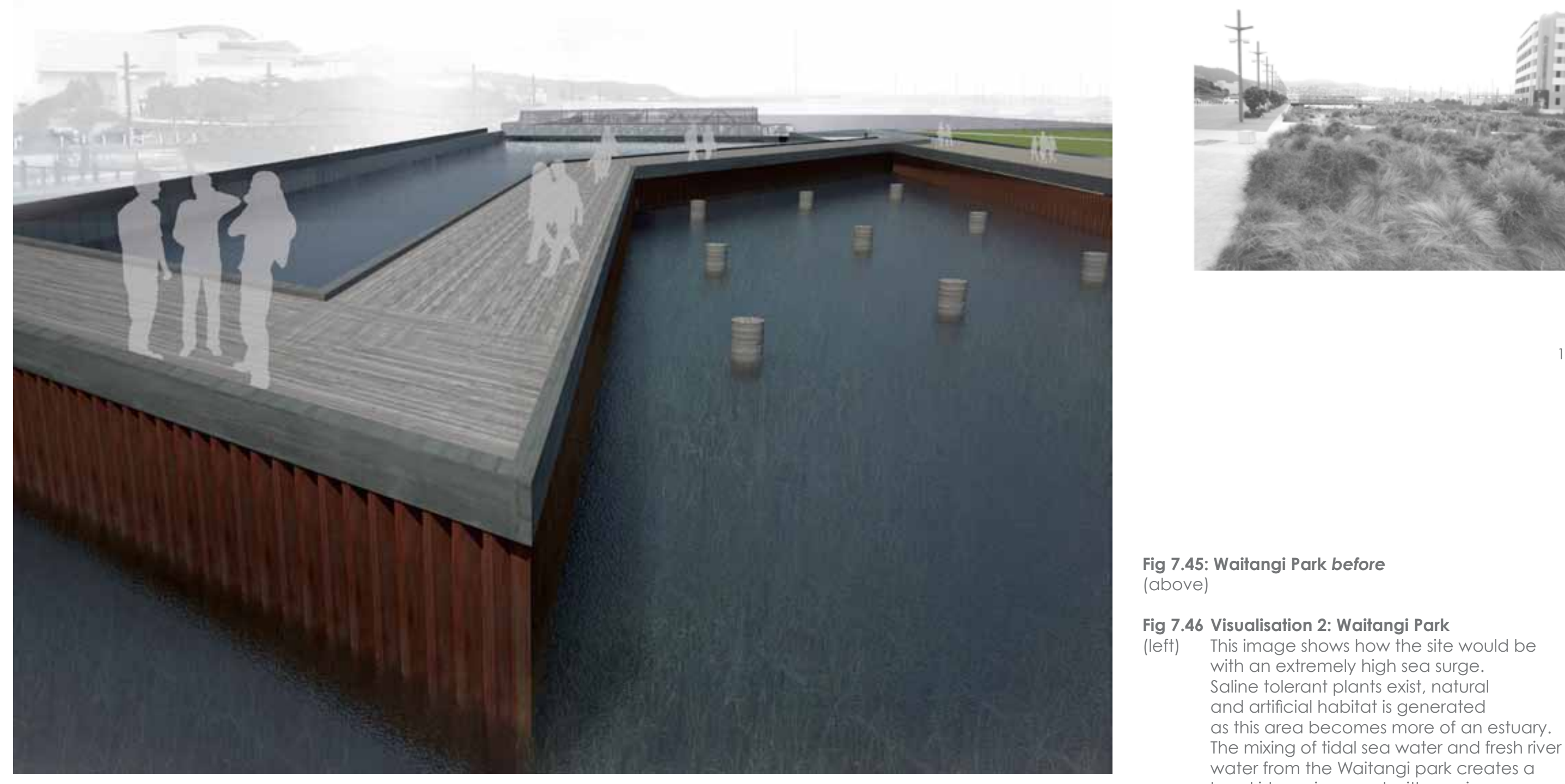

Fig 7.45: Waitangi Park before

(above)

Fig 7.46 Visualisation 2: Waitangi Park

(left) This image shows how the site would be

with an extremely high sea surge.

Saline tolerant plants exist, natura

and artificial habitat is generated

as this area becomes more of an estuary.

The mixing of tidal sea water and fresh river

water from the Waitangi park creates a

brackish environment with varying

levels of salinity. Here the sea wall

is exposed to show the vinyl piling's

structural form. A walkway is created

along the wall making way for a new

seawall promenade. 


$$
\text { mrgar ofors }
$$




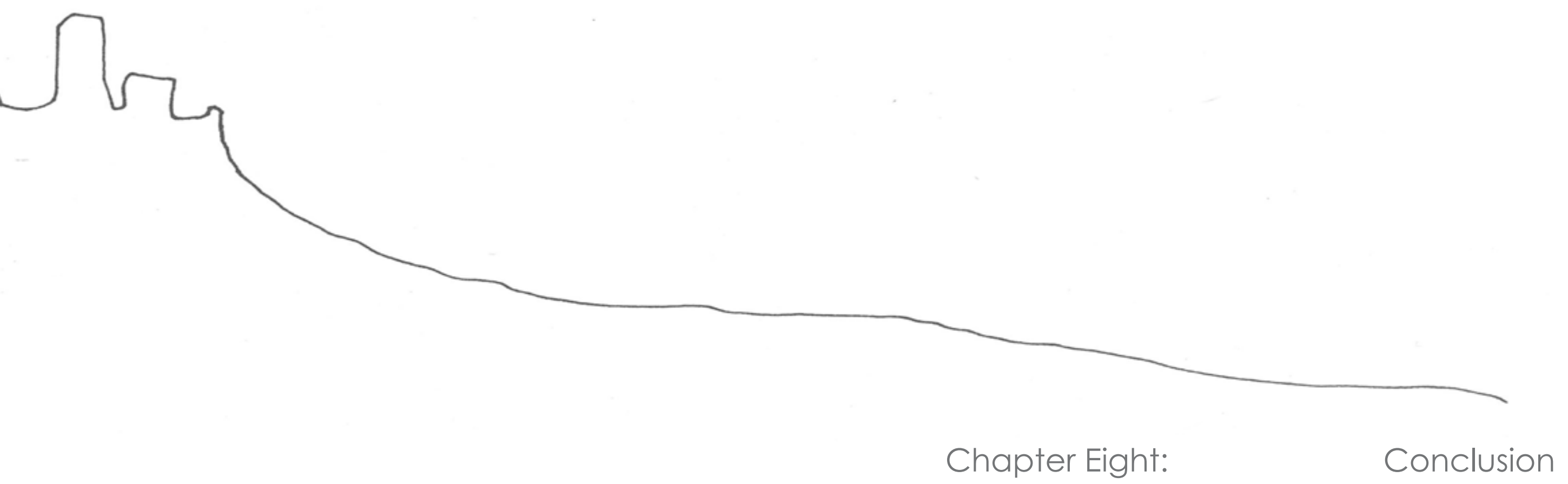


This thesis has thoroughly investigated a viable solution to sea level rise for Wellington City. The final design is an urban design response with two elements: a seawall within the harbour boundaries, and an amphibious landscape on its seaward side.

The design response achieves the main objectives. See table 8.1 for details.

- Increase connections between city and sea;

- Maintain the essential character of Wellington's iconic waterfront;

- Introduce new urban norms that acknowledge rises in sea levels, and;

- Protect the central city from high tides and sea surges.

The sea wall is a varying landscape element, which succeeds in providing users with a range of beneficial functions. The placement of the wall inside the waterfront, rather than around it, has ensured that the fundamental essence of the waterfront promenade has been preserved. The wall is a continuous barrier which protects the central city from high tides and sea surges. It is an iconic structure, while remaining intrinsically Wellingtonian.

Wellington City contains extensive and invaluable infrastructure'. Should sea levels rise significantly, it is highly likely that the choice will be made to protect the city. The wall is designed so it can be implemented relatively quickly, with little damage to surrounding buildings and public spaces. This is an advantage as action need only be taken when threats become certainties.

The sea wall does not impede dramatically on current inner-city circulation systems and public waterfront spaces. Numerous opportunities are provided for the public to interact with the structure and the surrounding waters, observing for themselves how the sea level is changing. The design provides access for cars, bicycles, pedestrians and disabled persons over and through the wall at regular intervals,.

The seawall has the advantage of being placed almost entirely on public land and within council control. If necessary, the council could also acquire the parts in which the sea wall enters private land, to ensure the structure remains entirely in public hands.
Table 8.1 Assessment of design occording to initial objectives (right)

1

A September 2009 valuation of 41,796 gross assessments found Wellington City's total capital value was $\$ 22,617$ million. Total land value was found to be $\$ 10,788$ million. Quotable Value Limited. Urban Property Sales Statistics: Half year ended June 2010. Wellington: Quotable Value Limited. 
Assessment of design according to initial objectives

\begin{tabular}{|l|l|l|l|}
\hline Main objectives: & Kumutoto Precinct & Frank Kitts Park & Waitangi Park \\
\hline $\begin{array}{l}\text { Protect the central city from high } \\
\text { tides and sea surges }\end{array}$ & Sea wall \& floodgates. & $\begin{array}{l}\text { Sea wall \& floodgates. Terraced } \\
\text { protection. }\end{array}$ & Sea wall \& wetlands. \\
\hline $\begin{array}{l}\text { Increase connections between city } \\
\text { and sea }\end{array}$ & $\begin{array}{l}\text { Sea wall is parallel with harbour-front } \\
\text { road with numerous crossing oppor- } \\
\text { tunities. The sea can now be ob- } \\
\text { served from within the city through } \\
\text { wall fingers, which extend to the } \\
\text { harbour-front road. }\end{array}$ & $\begin{array}{l}\text { Frank Kitts Park is redesigned to } \\
\text { improve connections between city } \\
\text { and sea. The sea wall is an integral } \\
\text { landscape element, celebrated in } \\
\text { the park's design. }\end{array}$ & $\begin{array}{l}\text { Sea wall is a landscape element } \\
\text { and harbour-front pathway. The sea } \\
\text { can now be observed from within } \\
\text { the city through the wall finger, } \\
\text { which extends under the harbour- } \\
\text { front road. }\end{array}$ \\
\hline $\begin{array}{l}\text { Maintain the essential character of } \\
\text { Wellington's iconic waterfront }\end{array}$ & $\begin{array}{l}\text { The majority of Kumutoto Precint } \\
\text { urban design is preserved. The am- } \\
\text { phibious zone, when not flooded, is } \\
\text { essentially the same as before. }\end{array}$ & $\begin{array}{l}\text { Frank Kitts Park will continue to } \\
\text { function as a park, and continue to } \\
\text { supply space for events. Children's } \\
\text { playground retained. Wide water- } \\
\text { front promenade retained. }\end{array}$ & $\begin{array}{l}\text { The majority of Waitangi Park urban } \\
\text { design is preserved. Freshwater wet- } \\
\text { lands continue to function. }\end{array}$ \\
\hline $\begin{array}{l}\text { Introduce new urban norms that } \\
\text { acknowledge rises in sea levels }\end{array}$ & $\begin{array}{l}\text { Amphibious zone: } \\
\text { Floating road. Terraced street pat- } \\
\text { tern with elevated causeways. } \\
\text { Wetland species in intertidal land. } \\
\text { New amphibious buildings. Meridian } \\
\text { Energy building needs to be made } \\
\text { more resilient. }\end{array}$ & $\begin{array}{l}\text { Amphibious zone: } \\
\text { Floating road. Terraced protection. } \\
\text { Saline tolerant plant species. }\end{array}$ & $\begin{array}{l}\text { Amphibious zone: } \\
\text { Floating road. Plant species in inter- } \\
\text { tidal land and shallow waters. Saline } \\
\text { tolerant plant species. New amphib- } \\
\text { ious building. Te Papa building and } \\
\text { adjacent Chaffers Dock apartment } \\
\text { building needs to be made more } \\
\text { resilient. }\end{array}$ \\
\hline
\end{tabular}


The amphibious zone allows Wellington City to introduce new urban norms and building processes - an exciting prospective urban landscape that responds seamlessly to an uncertain rise in sea level.

Rather than being a threat to the city's existence, sea level rise offers an opportunity to enhance our environment.

There are many obstacles to initiating a major urban strategy. It is clear that the decision to take this form of action needs to involve community participation throughout all its stages. Uncertainties should be acknowledged, transparent and traceable throughout assessment (Bornman, 2010, p. 12).

The general public may find the prospect of sea level rise hard to visualise, as the event is unlikely in their lifetime. Any changes to urban infrastructure will need to be planned very carefully over several decades. We should also be beginning to save for it; taxpayers will protest fiercely if there is a sudden unexpected demand for payment to protect the next generation. Affected landowners will also expect compensation - and should receive it in some form or other.

Details will include which activities require resource consent, how the activities are carried out, who will own the wall and/or amphibious buildings and for what use, where the buildings are located and their height. Appropriate building technologies could be selected on the basis of flood risk. The designs must be flexible - it will need to evolve as community needs and aspirations change. The introduction of the amphibious zone is likely to be initially met with public disapproval and controversy. Those in control must demonstrate that the development will be safe without increasing risk elsewhere.

Officials must look to successful examples of similar projects for insight into effective ways of engaging with the community, such as the case study Waitakere's Project Twin Streams.

A widely publicised global architectural competition for environmentally sensitive floating housing could prove popular with citizens, if they were given the opportunity to vote for their preferred option. 
Hgh level of municipal control will be needed once this design has been implemented. The sea wall will need continuous maintenance and reinforcement to make sure that it is continuously impermeable. The amphibious development will need to be carefully controlled with a framework to evaluate existing buildings as suitable for retrofit or replacement. The operation must also be relatively flexible to allow for new technologies and building practices.

As a response to one scenario only - one metre rise in sea level by the year 2100 - the design of a combination of sea wall and amphibious zone meets its initial aims.

However, it does not respond fully to the upper bound of projections. If sea levels were to rise further than $1.5 \mathrm{~m}$ by 2100 , this urban design approach may not be applicable. A sea wall could be constructed/made higher, and an amphibious zone is still possible, however, major changes to the urban design approach would be needed.

Many coastal cities are more urgently affected than Wellington and are already facing challenges related to sea level rise. As technology and design models around the world adapt and evolve, so too will the plans put in place to respond to sea level rise for Wellington City.

"The problems that exist in the world today cannot be solved by the level of thinking that created them." 


\section{References}

Anderson, G. (1984). Fresh About Cook Strait: An Appreciation of Wellington Harbour . Auckland: Methuen Publications (NZ) Ltd.

Anderson, W. (2009). Homes for a Changing Climate: Adopting our homes and communities to cope with the climate of the 21 st century. Totnes: Green Books.

Anonymous. (2009, October 27). Calls for drastic action to address rising sea levels. AAP Finance News Wire.

Arnold, M. a. (2003). Building Safer Cities, The future of Disaster Risk. (M. A. Alcira Kreimer, Ed.) Washington: The World Bank Disaster Management Facility.

Atlas Communications and Media. (2010). Prepared for the Ministry for the Environment: Largescale property purchase without recourse to compulsory purchase: A Project Twin Streams Case Study. Ministry for the Environment. Wellington: Ministry for the Environment.

Balmer, R. (2009, May). Briefing Note: Thames Barrier. Retrieved June 2010 from Collaborative Information Xchange (CIX) Online: www.cix.co.uk/ aldes/papers/ALDThamesBarrier509.pdf

Bell, R. a. (2002). Planning on Rising Sea Level? Planning Quarterly , 13-16.

Bentley, lan. (1985). Responsive Environments: A Manual for Designers. London: The Architectural Press.

Bicknell, J. a. (2009). Adapting Cities to Climate Change: Understanding and Addressing the Development Challenges. London: Earthscan.

Bicknell, J. a. (2009). Adapting cities to climate change : understanding and addressing the development challenges. London: Earthscan.

Bornman, J. N. (2010, February). Report: Climate change adaptation in New Zealand:Future scenarios and some sectoral perspectives. Retrieved 20 September, 2010 from New Zealand Climate Change Centre 2010.: http://www.nzclimatechangecentre.org/sites/ nzclimatechangecentre.org/files/images/research/Climate\%20change\%20adaptation\%20in\%20 New\%20Zealand\%20\%28NZCCC\%29\%20\%28A4\%20low\%29.pdf

Burton, I. a. (Ed.). (2009). The Earthscan Reader on Adaptation to Climate Change (1 ed.). London: Earthscan.

CABE. (n.d.). Cleavelys New Wave. Retrieved 10 May, 2010 from Commission for Architecture and the Built Environment: http://www.cabe.org.uk/case-studies/cleveleys-new-wave/description

CABE. (2001). Inquiry into Walking in Towns and Cities, Session 2000/2001. CABE, House of 
Commons Environment, Transport and Regional Affairs Select Committee. London: CABE.

CABE. (2008, September 15). The Thames Gateway design pact . Retrieved May 15, 2010 from

CABE: http://www.cabe.org.uk/publications/the-thames-gateway-design-pact

Carmona, M. a. (2007). Urban Design Reader (Vol. 1). London: Architectural Press.

Chug, K. (2010, June 29). Capital 'needs to set priorities' for protection from sea level rise.

Dominion Post.

Civils, B. (2007, April 25). Birse Coastal \& Wyre Borough Council win prestigious, top safety award. Retrieved May 1 1, 2010 from Birse Civils: http://www.birsecl.co.uk/html/birse-coastal/latest-news/ view/BirseCoastalWyreBoroughCouncilwinprestigioustopsafetyaward.htmle ContentID=9

Cleveleys Sea Defence Works. (2007, April 2010). Scheme Awards. Retrieved May 11, 2010 from Cleveleys Seawall: http://www.cleveleys-seawall.co.uk/Scheme\%20Awards.htm

Cowan, R. (2005). The Dictionary of Urbanism (Vol. 1). Tisbury: Streetwise Press Limited.

C-X Stream. (2010). Albert Einstein Quotes. Retrieved November 29, 2010, from Albert Einstein Site: http://www.alberteinsteinsite.com/quotes/einsteinquotes.html

Department of Conservation. (2010). New Zealand Coastal Policy Statement Review. Retrieved June 2, 2010 from Department of Conservation: http://www.mfe.govt.nz/rma/central/nps/ coastal.html

Department of Conservation. (2008, March). Proposed: New Zealand Coastal Policy Statement 2008. Retrieved August 2010 from Department of Conservation: http://www.doc.govt.nz/ publications/getting-involved/consultations/closed/proposed-new-zealand-coastal-policystatement-2008/

Douglas, B. C. (Ed.). (2001). Sea Level Rise, History and Consequences (Vol. 75). San Diego: Academic Press.

Downing, K. D. (2007). The Atlas of Climate Change, Mapping the World's Greatest Challenge (2 ed.). Hong Kong: University fo California Press.

Edensor, T. (2006). Caudan: Domesticating the Global Waterfront. In D. Bell, Small Cities: Urban Experience Beyond the Metropolis (pp. 205-216). New York: Routledge.

English Partnerships and Housing Corporation. (2007). Urban Design Compendium. London: Llewelyn-Davies.

Evans, I. (2009, July 8). Byron Bay to be abandoned to the waves. Retrieved November 9, 2010, from http://www.crikey.com.au/2009/07/08/byron-bay-to-be-abandoned-to-the-waves/

Fransje Hooimeijer, H. M. (2005). Atlas of Dutch Water Cities. Amsterdam: SUN. 
Fyfe, M. (2009, November 13). Sea level rules need to go further: mayor. The Age .

Gastil, R. W. (2002). Beyond the Edge: New York's New Waterfront. New York: Princeton Architectural Press.

Gehl, J. (2004). City to Waterfront: public spaces and public life study: Wellington, October 2004. Wellington: Wellington City Council.

Greater Wellington Regional Council (GWRC). (2009, October 13). Restrictions on use of the coastal marine area: Section 12 of the Resource Management Act, 1991 Retrieved November 30, 2010 from Greater Wellington Regional Council: http://www.gw.govt.nz/restrictions-on-use-of-thecoastal-marine-area/

Greater Wellington Regional Council (GWRC). (2009, October 10). About GW and the RegionRegional, City or District Council? Retrieved November 27, 2010 from Greater Wellington Regional Council: http://www.gw.govt.nz/Regional-city-or-district-council-/

Greater Wellington Regional Council (GWRC). (2007, September). East Harbour Regional Park Resource Statement. Retrieved November 10, 2010 from Greater Wellington Regional Council: http://www.google.co.nz/url2sa=t\&source=web\&cd=1 \&ved=0CBCQFjAA\&url=http\%3A\%2F\%2Fwww.gw.govt.

nz\%2Fassets\%2Fcouncil-publications\%2FEast\%2520Harbour\%2520RP\%2520resource\%2520doc.pdf\&ei=DBP4TINNZL4swOZrd2 WAQ\&usg=AFQjCNHyyISHGjxLtLVpOMJHVsi7PzbVZQ\&sig2=0vhOK9iJd5uUHMeDnEBdKA

Heckscher, A. (1977). Open Spaces: The Life of American Cities (1 ed.). New York: Harper \& Row, Publishers.

Intergovernmental Panel on Climate Change. (2001). Climate Change 2001: Working Group II: Impacts, Adaptation and Vulnerability. (O. F. James J. McCarthy, Ed.) Retrieved August 2010 from Intergovernmental Panel on Climate Change: http://www.ipcc.ch/ipccreports/tar/wg2/index. htm

Intergovernmental Panel on Climate Change. (2007). Climate Change 2007 Synthesis Report: Contribution of Working Groups I,Il and III to the Fourth Assessment Report of the Intergovernmental Panel on Climate Change. (R. a. Pachuari, Ed.) Retrieved August 2010 from Intergovernmental Panel on Climate Change: http://www.ipcc.ch/publications_and_data/ar4/ syr/en/contents.htm

Johnstone, T. (2010, October 30). Trouble's rising: Buyers feel it in their waters. Retrieved November 2, 2010 from The Canberra Times: smh.domain.com.au/.../troubles-rising--buyers-feel-it-in-theirwaters-20101029-177ig.html

King, J. (2009, July 15). Designers answer call to fight rising seas. Retrieved November 5, 2010 from SF Gate: San Fransisco Chronicle: http://www.sfgate.com/cgi-bin/article.cgi?f=/c/a/2009/07/14/ MNAI18OFT1.DTL 
Lang, J. (2005). Urban Design: A typology of procedures and products. Burlington: Architectural Press.

Local Government New Zealand. (2010, November). Role of Local Government. Retrieved November 27, 2010 from Local Government New Zealand: http://www.lgnz.co.nz/lg-sector/role/ index.html

London Boroughs of Greenwich and Bexley. (2005, March). Exploring London's Working River. Retrieved May 2010, 15 from Visit London: http://static.visitlondon.com/assets/llondons_working_ river.pdf

McCarthy, J. J. (2001). Climate Change 2001: Impacts, Adaptation, and Vulnerability . Cambridge: Intergovernmental Panel on Climate Change.

Maclean, C. (2009, November 24). Wellington region - Arts and culture. Retrieved November 28 , 2010 from Te Ara - the Encyclopedia of New Zealand: http://www.teara.govt.nz/en/wellingtonregion $/ 15$

Maclean, C. (2010, May 30). Wellington Region: Population. Retrieved November 28, 2010 from Te Ara - the Encyclopedia of New Zealand: http://www.teara.govt.nz/en/wellington-region/12

McFadden, L. a.-R. (Ed.). (2007). Managing Coastal Vulnerability. Amsterdam: Elsevier.

McGill, D. (2003). Wellington: A Capital Century. Wellington: Transpress.

Ministry for the Environment. (2001). Climate Change Impacts in New Zealand. Retrieved July 2010 from New Zealand Ministry for the Environment: http://www.mfe.govt.nz/publications/ climate/impacts-report/index.html

MoMa. (2010). Exhibitions: Rising Currents: Projects for New York's Waterfront. Retrieved July 30 , 2010 from MoMa: www.moma.org/visit/calendar/exhibitions/1031

New Zealand Climate Change Programme. (2001, September). Planning for Climate Change Effects on Coastal Margins. (T. H. RG Bell, Ed.) Retrieved August 2010 from Ministry for the Environment: http://www.mfe.govt.nz/publications/climate/effect-coastal-sep01/

New Zealand Government. (1994). New Zealand Coastal Policy Statement. Retrieved August 2010 from New Zealand Government: http://www.doc.govt.nz/upload/documents/ conservation/marine-and-coastal/coastal-management/nz-coastal-policy-statement.pdf

Nordenson, G. A. (2010). On the Water: Palisade Bay. New York: Museum of Modern Art.

Nordenson, G. A. (2008, October 15). On the Water: The New York - New Jersey. Retrieved April 27, 2010 from The Design Observer Group: http://places.designobserver.com/entry. $\mathrm{html}$ ? entry=678 
Ouroussoff, N. (2009, October 22). Future Dangers for a Maritime City. New York Times, p. C3.

Peart, R. (2007). Beyond the Tide, Integrating the Management of New Zealand's Coasts (1 ed.). Auckland, New Zealand: Environmental Defence Society.

Palca, J. (2008, Janurary 28). Dutch Architects Plan for a Floating Future : NPR. Retrieved April 1 2010 from National Public Radio: http://www.npr.org/templates/story/story.php?storyld=18480769

Pilkey, O. H. (2009). The Rising Sea. Washington: Island Press.

Project Twin Streams. (2010). Project Twin Streams: About. Retrieved November 9, 2010, from

Project Twin Streams: http://www.projecttwinstreams.com

Punter, J. (2003). The Vancouver Achievement. Vancouver: University of British Columbia Press.

Quotable Value Limited. Urban Property Sales Statistics: Half year ended June 2010. Wellington: Quotable Value Limited.

Raewyn. (2009). Castles in the Sand: Whats Happening to the New Zealand Coast? Nelson: Craig Potton Publishing.

Ramsay, D. a. (2008, July). Costal Hazards Climate Change Guidance Manual: A guidance manual for local government in New Zealand. (D. a. Ramsay, Ed.) Retrieved August 2010 from http://www.mfe.govt.nz/publications/climate/coastal-hazards-climate-change-guidancemanual/

Recreational Access New Zealand. (2003, February 18). Queen's Chain. Retrieved July 10, 2010 from Access New Zealand: http://www.recreationaccess.org.nz/files/queens_chain.html

RG Bell, T. H. (2001). Planning for Climate Change Effects on Coastal Margins. New Zealand Ministry for the Environment, New Zealand Climate Cange Programme. Wellington: Ministry for the Environment.

Rising Tides Competition. (2009). Rising Tides: About the Competition. Retrieved July 30, 2010 from Rising Tides Competition: http://www.risingtidescompetition.com/risingtides/About.html

Sample, I. (2009, Februrary 16). The Tropics of Fire: Scientist's Grim vision of Global Warming. The Guardian , p. 8.

Sandercock, L. (2006). An Anatomy of Civic Ambition in Vancouver: Toward Human Density. In W. S. Saunders, Urban Planning Today (pp. 48-62). Minneapolis: University of Minnesota Press.

Shaftoe, H. (2008). Convival Urban Spaces: Creating Effective Public Places. Trowbridge, England: Earthscan.

Smulian, M. (2008, October 3). Blackpool doubles up to defend future as Resort . Planning , p. 20. 
State, S. B. (2009, July 3). Rising Oceans of Anger in Byron. The Daily Telegraph , p. 25.

Terradaily. (2007, December 12). After centuries of keeping water out, the Dutch now letting it in. Retrieved May 1 1, 2010 from Terradaily: http://www.terradaily.com/reports/After_centuries_of_ keeping_water_out_the_Dutch_now_letting_it_in_999.html

Statistics New Zealand. (2006). Are New Zealanders living closer to the coast? Retrieved July 11, 2010 from Statistics New Zealand: http://www.stats.govt.nz/browse for stats/population/ migration/internal-migration/are-nzs-living-closer-to-coast.aspx

Storm, L. (2002). Target Taupo: The Queen's Chain. Retrieved July 12, 2010 from Department of Conservation: http://www.doc.govt.nz/publications/parks-and-recreation/activities/fishing/ target-taupo/the-queens-chain/]

The Association of British Insurers (ABI). (2009, July). Risk Management Plan: Environment Agency Consultation. Retrieved September 10, 2010 from The Association of British Insurers : [Pwww.abi. org.uk/Bulletins/Newsletters/2009/09/43797.pdf

The Environment Agency. (2010, April 29). Flood defences. Retrieved May 13, 2010 from The Environment Agency: http://www.environment-agency.gov.uk/homeandleisure/floods/31738. aspx

The International Bank for Reconstruction and Development. (2003). Building Safer Cities, The future of Disaster Risk. (M. A. Alcira Kreimer, Ed.) Washington: The World Bank Disaster Management Facility.

Tor Erik Frydenlund, R. (2001, December). Long Term Performance of EPS as a Lightweight Filling Material. Retrieved September 10, 2010 from Styrotech: www.styrotech.com/downloads/data geofoam_durability.pdf

Trotman, R. (2005, October). Project Twin Streams Cycle and Walkway Programme. Retrieved November 9, 2010, from Waitakere City Council: www.waitakere.govt.nz/abtcit/cp/pdf/ twinstreams.pdf

Turbott, C. (2006). Environment Waikato Technical Report 2006/48: Managed Retreat from Coastal Hazards: Options for Implementation. Environment Waikato Regional Council. Hamilton: Environment Waikato Regional Council.

Urgenda. (2008, October). Prospectus Floating EcoCity. Retrieved November 19, 2010 from Urgenda: $h t t p: / / w w w . g o o g l e . c o . n z / u r l ? s a=t \&$ source=web\&cd=1 \&ved=0CBCQFjAA\&url=http\%3A\%2F\%2Fwww. urgenda.nl\%2Fdocuments\%2FProspectus\%2520Floating\%2520EcoCity\%2520ENG.pdf\&rct=j\&q=Prospectus\%20 Floating\%20EcoCity\%20urgenda\&ei=0hP4TK3vGZCCsQPBZaGBAg\&usg=AFQjCNHvcUNqf79gLAbqTODHqT8AJwTMA\&sig2=vZC8K1EtLLWKXmCoK532Pw

Warren, F. J. (2007). Climate Change Impacts and Adaptation: A Canadian Perspective Adaptation. Ontario: Climate Change Impacts and Adaptation Directorate, Natural Resources Canada. 
Waitakere City Council. (2009, May 5). Twin Streams Project: Common Ground for Environmental Sustainability. Retrieved November 9, 2010, from Cities of Migration: http://citiesofmigration.ca/ twin-streams-project-common-ground-for-environmental-sustainability/lang/en/

Waterfront Leadership Group. (2001). Wellington Waterfront Framework. Waterfront Leadership Group. Wellington: Lithoprint.

Waterstudio. (2010). New Water, Naaldwijk. Retrieved May 15, 2010 from Waterstudio.NL: http:// www.waterstudio.nl/en/projects/47_ps_New\%20Water.html

Waterstudio. (2010). The Citadel. Retrieved May 2010, 13 from Waterstudio.NL: http://www. waterstudio.nl/en/projects/54_pa_The\%20Citadel.html

Wellington City Council. (2010). About Wellington. Retrieved November 17, 2010 from Wellington City Council: http://www.wellington.govt.nz/aboutwgtn/glance/index.html

Wellington City Council. (2010, August 25). Annual Report 2009/10. Retrieved November 4, 2010 from Wellington City Council: http://www.wellington.govt.nz/plans/annualreport/0910/index.html

Wellington City Council. (2010). District Plan: Introduction. Retrieved May 18, 2010 from Wellington City Council: http://www.wellington.govt.nz/plans/district/districtplan.html

Wellington City Council. (2010, April). Draft: Climate Change Action Plan. Retrieved August 2010 from Wellington City Council: http://www.wellington.govt.nz/plans/dap/pdfs/climatechangeplan.pdf

Wellington City Council. (2009). Variation 11: Amendments to Proposed District Plan Change 48 (Central Area Review) - Wellington Waterfront. Retrieved November 24, 2010 from Wellington City Council: http://www.wellington.govt.nz/plans/district/planchanges/variations/variation 1 1.html

Wellington City Council. (2010. August 25). Wellington City Council. Retrieved November 4. 2010 from Annual Report 2009/10: http://www.wellington.govt.nz/plans/annualreport/0910/index.html

Wellington City Council. (2004). Wellington: our sense of place. Retrieved November 5, 2010 from Wellington City Council: www.wellington.govt.nz/aboutwgtn/pdfs/senseofplace.pdf

Wellington City Council. (2000). Wellington City District Plan: Central Area Design Guide.

Retrieved August 2010 from Wellington City Council: http://www.wellington.govt.nz/plans/district/ volume2/pdfs/v2central.pdf

Wellington Regional Strategy. (2010). Wellington Regional Strategy - About Us. Retrieved November 27, 2010 from Wellington Regional Strategy: http://www.wrs.govt.nz/about_us/

Wellington Waterfront Ltd. (WWL). (n.d.). History: Waterfront Reclamation. Retrieved May 17, 2010 from Wellington Waterfront: http://www.wellingtonwaterfront.co.nz/history/

Wellington Waterfront Ltd. (WWL). (n.d.). Waterfront Reclamations. Retrieved May 17, 2010 from 
Wellington Waterfront: http://www.wellingtonwaterfront.co.nz/history/waterfront_reclamation/

Wellington Waterfront Ltd. (WWL). (n.d). Development. Retrieved May 19, 2010 from Wellington Waterfront: http://www.wellingtonwaterfront.co.nz/development

Wellington Waterfront Ltd. (2010). Wellington Waterfront. Retrieved November 10, 2010 from Waitangi Park Introduction: http://www.wellingtonwaterfront.co.nz/development/waitangi/ waitangi_park_introduction/

Willis, C. (Ed.). (2002). The Lower Manhattan Plan: The 1966 Vision for Downtown New York. New York: Princeton Architectural Press.

Wilson, C. A. (1932). Legend and Mysteries of the Maori. London: George G. Harrap \& Co. Ltd.

Zevenbergen, D. C. (n.d.). Amphibious Houses: Dura Vermeer Ruimtelijke Ontwikkelirg

BV. Retrieved April 01, 2010 from duravermeerbusinessdevelopment: http://www.

duravermeerbusinessdevelopment.nl/uk/project_info.asp?id=579 


\section{Appendices}

Appendix One: Existing Sea Walls

Appendix Two: Expanded Polystyrene (EPS)

Appendix Three: Geoflex Vinyl Sheet Pile System

Appendix Four: Floodgates 


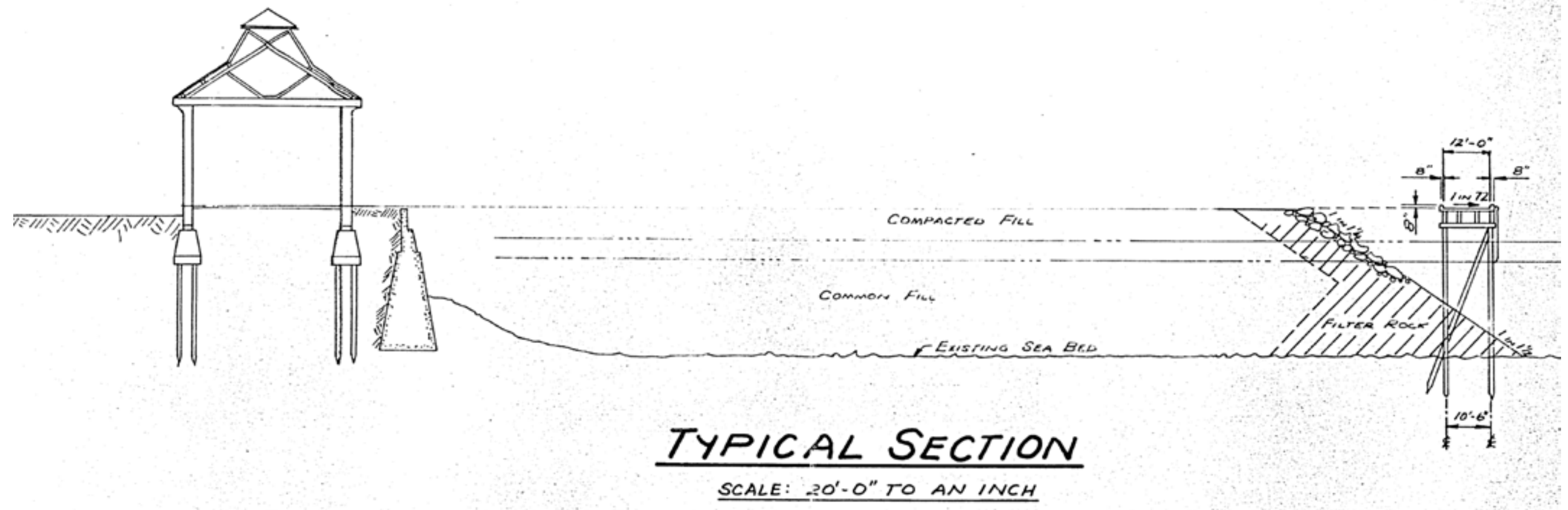




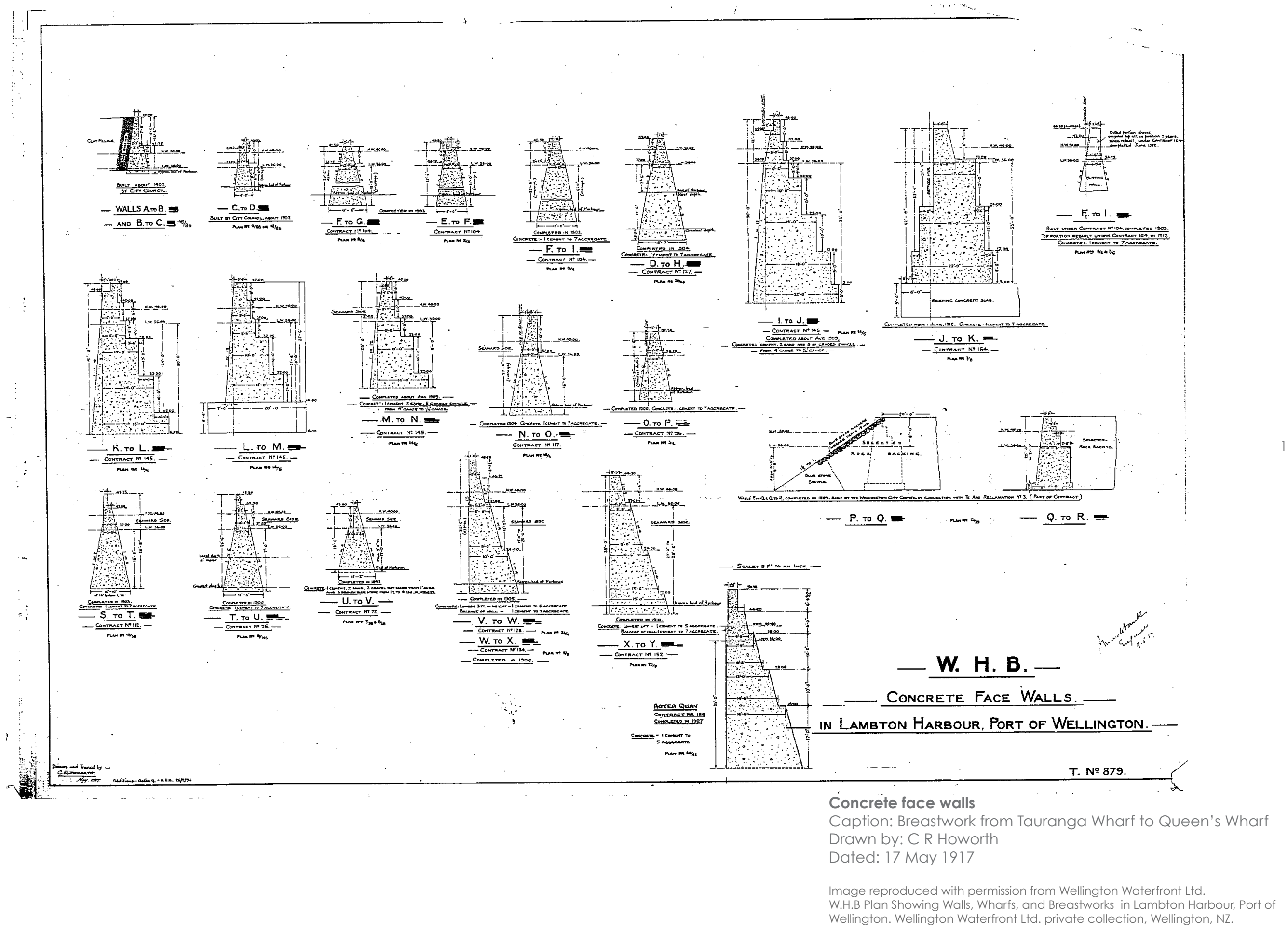


Ultra-Lightweight Fill Material

\section{GEDFOAN}

\section{Geotechnical Applications for Expanded Polystyrene Foam}
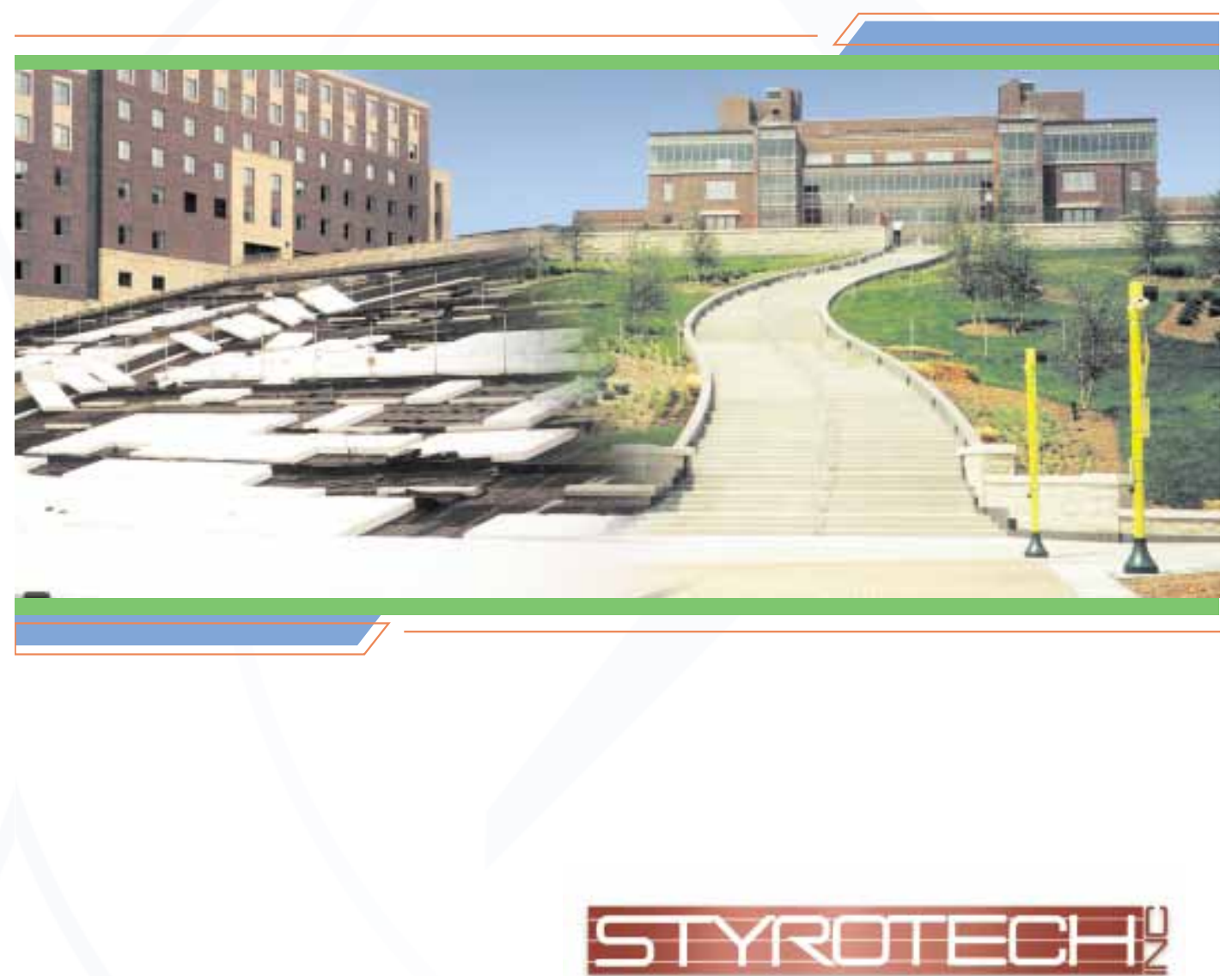

Innovative Foam Solutions

Styrotech Geofoam brochure

[From Styrofoam Website]

Retrieved November 2010 from: www.styrotech.com/products geofoam.html

\section{$G E \square=\square \Delta \mathrm{N}$}

\section{A Modern Solution For Age-Old Problems}

Expanded polystyrene (EPS) geofoam has been used throughout the world for over 30 years in applications where ultra-lightweight fill material has been specified for

STYRO-FLEX EPS Geofoam provides cost-effective solutions where conventional construction methods have failed or shown sub-standard performance. Unlike traditionalengineering and construction practices that work to resist the forces of nature, geofoam is designed to work with em. Geofoam's success derives from the fact that it is often more cost-effective to reduce the forces acting on a tructure or foundation soil than it is to reinforce them to withstand the forces that would exist without geofom?

foundation soils

Reduction of
vertical walls

substitution.

- Stress reduction

- Temperature control and/or frost protection

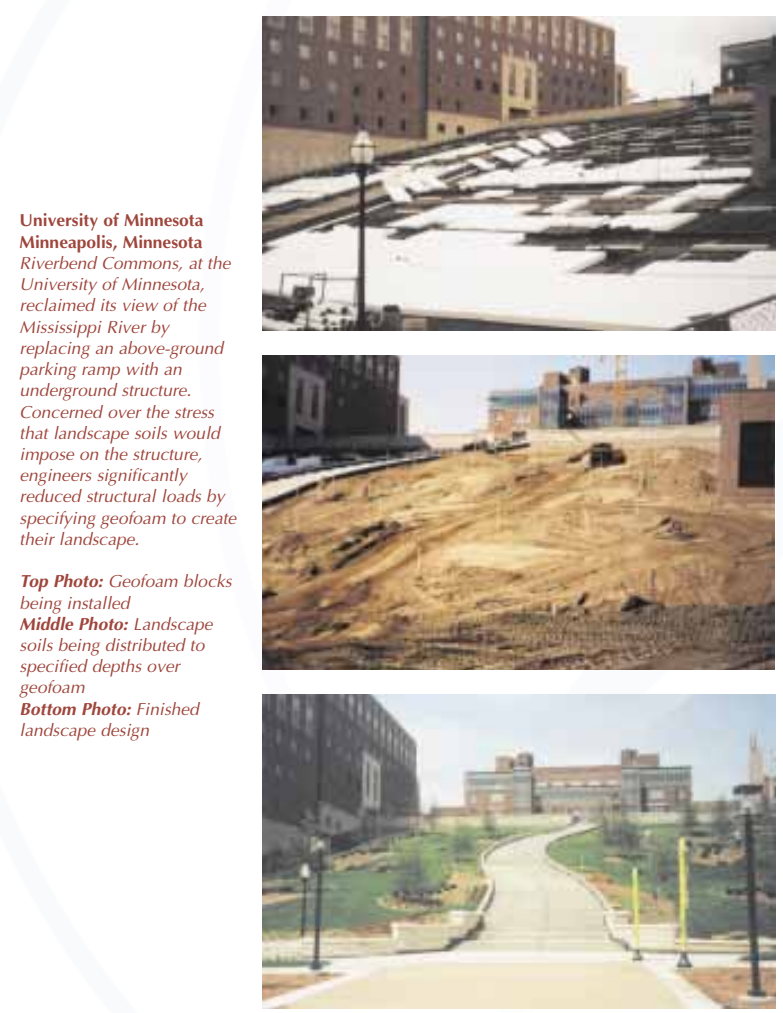

Proven Performance Makes EPS Geofoam the Right Choice

Although relatively new to the U.S. engineering community, EPS geofoam has a long history of success dating back to the 1960s when the Norwegian Road Research Laboratory (NRRL) began using geofoam to constryct road embankmens from these early projects were recently excavated and submitted for testing. These test results indicate that even after 30 plus years of service, EPS geofoam experienced no depreciation of its physical properties.

EPS geofoam is the material of choice for engineers around the world because effectiveness, design flexibility and documented history of performance. 


\section{EPS Geofoam}

Advantages

- Ultra-Lightweight

EPS geofoam weighs only

$1.00-2.00 \mathrm{lb} / \mathrm{tt}^{3}$, approximately $1 \%$

the density of soil or rock.

Reduced Construction Times

EPS geofoam construction is very fast,

particularly beneficial with

- Predictable Material Behavior

EPS geofoam is an engineered

product, unlike other lightweight fill

materials that can be variable in

composition.

EPS geofoam physical properties will

not degrade, assuring long-term

performance in engineered

- Inert

EPS geofoam will not leach into

surrounding soils or groundwater and

provides no nutritive value for plants

\section{Geofoam Applications}

STYRO-FLEX EPS Geofoam is a versatile material that provides innovative

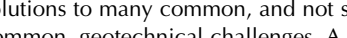
cost-effective alternative to traditional construction practices, EPS geofoam has documented benefits in the following applications:

- Road Embankments

- Bridge Approach Fil

- Slope Stabilization

- Earth Retaining Structure

- Plaza Decks

- Structural Foundations

- Compressible Inclusions

- Dikes/Berms/Levees

- Landscape Fill

- Insulation/Frost Protection

Note: Other engineered applications may also be appropriate for STYRO-FLEX EPS Geofoam.

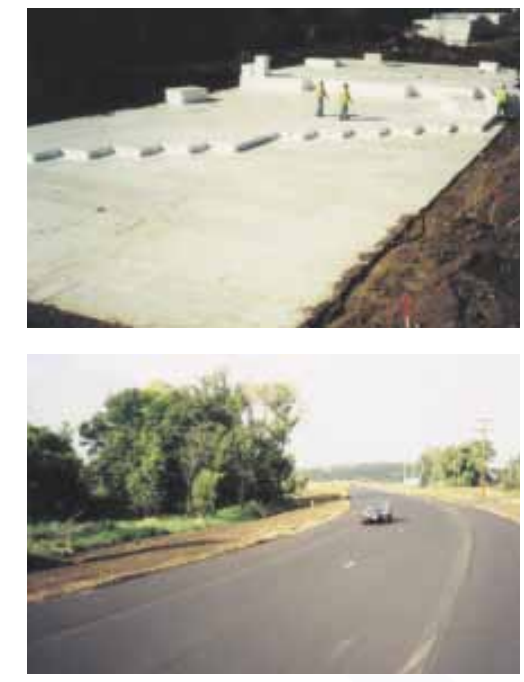

County Highway 12
Elk River, Minnesota

Coposits $22^{\prime}-28^{\prime}$ ' deep
County Highway 12

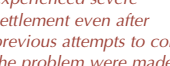

With minimal excavation
geofoam road embankmen
was constructed to reduce

the overburden on the
underlying poor soils

Iop Photo: Construction of
eofoam road embankment

Bottom Photo: eN New $200^{\prime}$

working days
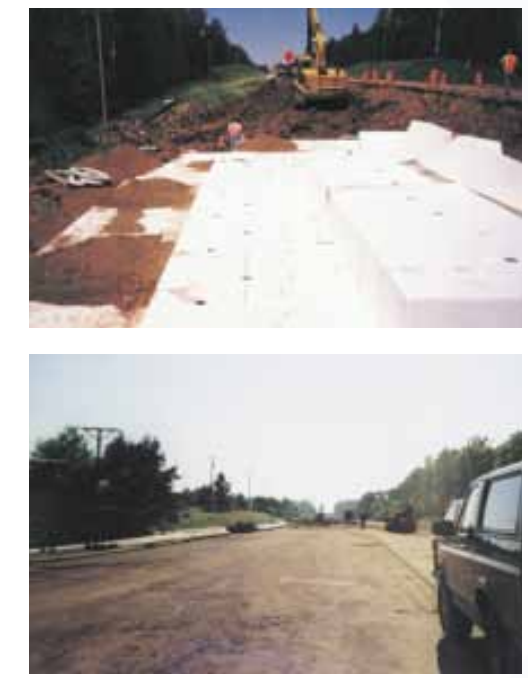

Typical Physical Properties of Styro-Flex EPS Geofoam

\begin{tabular}{|c|c|c|c|c|c|c|}
\hline \multirow{2}{*}{\multicolumn{3}{|c|}{ 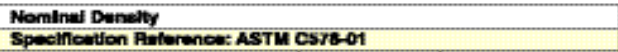 }} & \multirow{3}{*}{$\begin{array}{l}1.00 * \\
\text { Typoel }\end{array}$} & \multirow{3}{*}{$\begin{array}{l}125 \% \\
\text { Typo vili }\end{array}$} & \multirow{3}{*}{$\frac{1.000}{\text { Typo II }}$} & \multirow{2}{*}{$\begin{array}{ll}2000 \\
\text { Type ix }\end{array}$} \\
\hline & & & & & & \\
\hline Poepertity, Mintimum & Unlles & casos or 01602 & & & & 180 \\
\hline 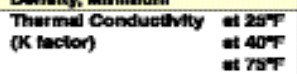 & 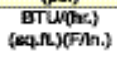 & C17 or Cs18 & $\begin{array}{l}0.23 \\
0.24\end{array}$ & $\begin{array}{l}0.22 \\
0.225 \\
0.2255\end{array}$ & 0.21 & 0.20 \\
\hline 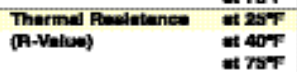 & $\begin{array}{l}\text { per inch } \\
\text { strickneess }\end{array}$ & & $\begin{array}{l}4.35 \\
4.17 \\
3.98\end{array}$ & 4.54 & $\begin{array}{l}4.78 \\
4.5 s\end{array}$ & $\begin{array}{l}8.00 \\
4.78\end{array}$ \\
\hline Strongin Propertio: & & & & & & \\
\hline 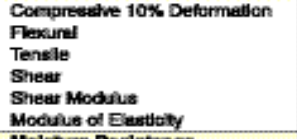 & 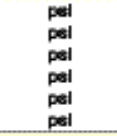 & $\begin{array}{l}\text { D1821 } \\
\text { C2033 } \\
\text { D1623 } \\
\text { Dra2 }\end{array}$ & $\begin{array}{l}10-14 \\
25-30 \\
16-20 \\
16-22 \\
200 \\
100 \\
100\end{array}$ & $\begin{array}{c}13-18 \\
30-16 \\
17-21 \\
22-25 \\
370 \\
250 \\
\end{array}$ & $\begin{array}{l}15-21 \\
20-50 \\
12-22 \\
26-32 \\
480 \\
320 \\
\end{array}$ & $\begin{array}{c}25-39 \\
50-75 \\
23-27 \\
33-37 \\
600 \\
400 \\
400\end{array}$ \\
\hline 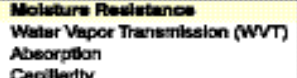 & $\begin{array}{l}\text { pern. in } \\
\mathbf{x}(\text { woul })\end{array}$ & $\cos 2$ & $\begin{array}{l}20.50 \\
\text { eeses then } 4.0\end{array}$ & $\begin{array}{ll}1.5 .3 .5 \\
\text { ieses then } 3.0\end{array}$ & 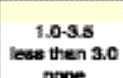 & $\begin{array}{l}0.82 .20 \\
\text { vesut that } 2.0\end{array}$ \\
\hline 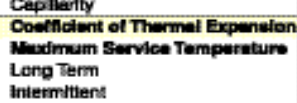 & 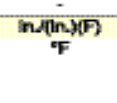 & $D 68$ & 0.000000 & $\begin{array}{l}\text { none } \\
0.000038\end{array}$ & $\begin{array}{l}\text { none } \\
0.000038 \\
165 \\
100\end{array}$ & $\begin{array}{l}\text { nore } \\
0.0000005 \\
167 \\
100\end{array}$ \\
\hline Flime Spreed & & Ear & & Leses tran 28 & all derables & \\
\hline & & & & Coss that & all deraibes & \\
\hline
\end{tabular}

County Highway A

Bayfield, Wisconsin
For over 20 years, County

Highway A had a history of
slope failures, and

Gailed to correct the problem

Iriving force without
bering the grade at the

\section{Why Styrotech}

\section{for your geofoam requirements?}

Whether considering or actively specifying geofoam in your designs, give Styrotech a call and let us go to work for you. For over a decade we have produced geofoam for a variety of geofoam technology has provided us with the background to help your projects proceed efficiently.

Experience - Styrotech has produced numerous geofoam Epets, for bohth the private and public sectors, hroughout the

Knowledge - Styrotech employs people who are experts in the industry, many with over 25 years of experience, ready to work lop Photo: Geotoam blocks
eing installed in the area of
ailure failure
Bottom Photo: Compacted
base course ready for asphalt
application

Capacity - Styrotech has one of the largest, state-of-the-art requirements for even the largest projects.
Service - Styrotech takes a "hands on" approach with geofoam projects from start to finish.

\section{Design Considerations}

Flammability - Like many construction materials, EPS is combustible and should not be exposed to flame or other ignition sources. Current model building code requirements should be

Solvent Exposure - EPS is subject to attack by petroleum-based solvents. Care should be taken to prevent contact between EPS for EPS applications.

Ultraviolet Exposure - Prolonged exposure of EPS to sunlight will cause slight discoloration and surface dusting, howeve outside, EPS insulation should be protected with a light-colored, opaque tarp.

Exposure/Application Temperatures - EPS should not be exposed for prolonged periods to temperatures in excess of $170^{\circ} \mathrm{F}$. insulating properties will not be significantly affected. If stored
137 
Appendix Three: Vinyl Sheet Pile System
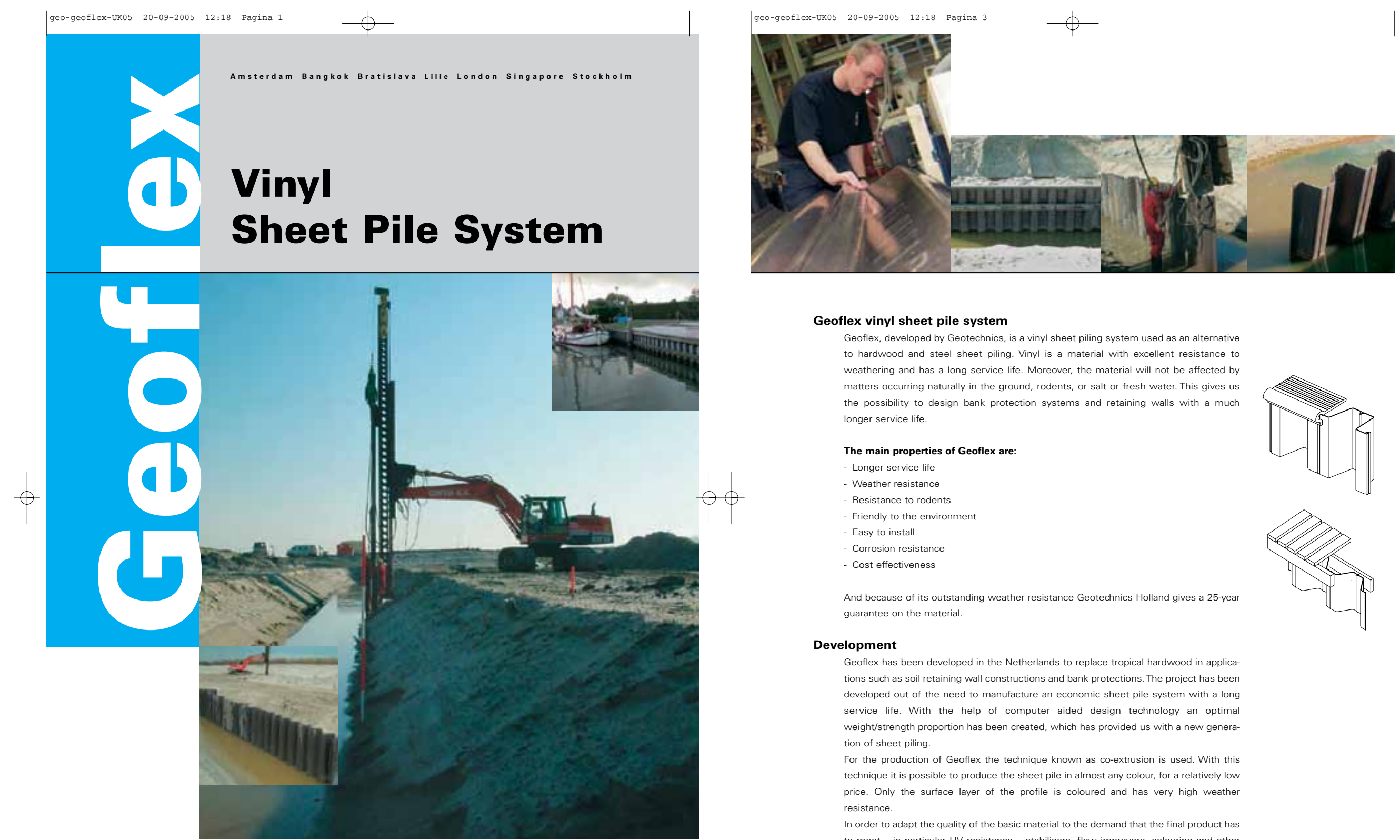

Geoflex, developed by Geotechnics, is a vinyl sheet piling system used as an alternative to hardwood and steel sheet piling. Vinyl is a material with excellent resistance to

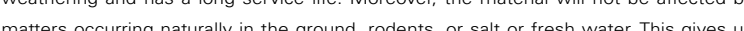
matters occurning naturaly in the ground, rodents, or salt or fresh water. This gives us

The main properties of Geoflex are:

Longer service life

- Weather resistance

- Resistance to rodents

- Easy to install

Corrosion resistance

And because of its outstand guarantee on the material.

velopment

Geoflex has been developed in the Netherlands to replace tropical hardwood in applicetions such as soil retaining wall constructions and bank protections. The project has been developed out of the need to manufacture an economic sheet pile system with a long service life. With the help of computer aided design technology an optima weight/strength proportion has been created, which has provided us with a new generaweight/strength prop
tion of sheet piling.

tion of sheet pling.

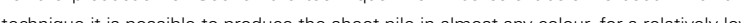

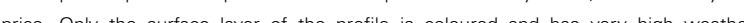
pice. Only pos a resistance.

In order to adapt the quality of the basic material to the demand that the final product has

G GEOTECHNICS BV

Geoflex Vinyl Sheet Pile System brochure

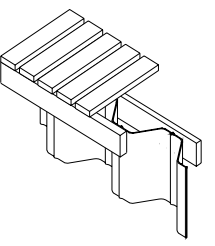


A sterdam Bangkok Bratislava Lille London Singapore Stockholm

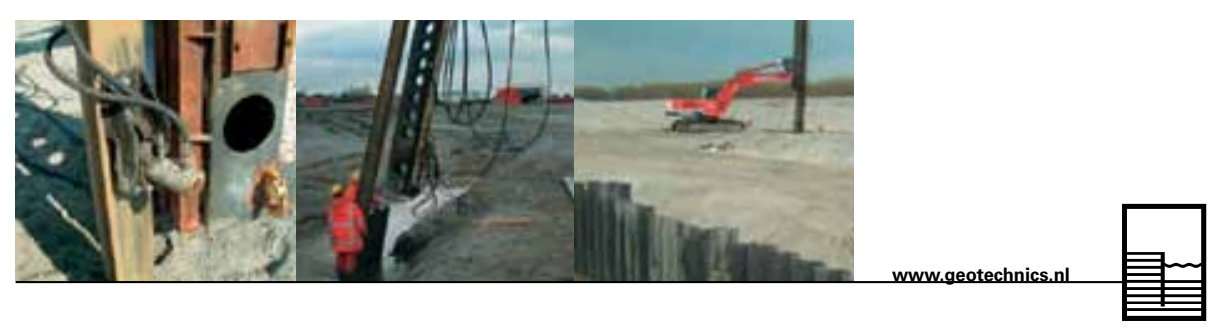

additives are added. By adding what are known as impact resistance improvers, the toughness of the vinyl is improved dramatically. It increases the resistance to mechanical damage and absorbs the impact pressure incurred during the driving of the sheets. Also at those places where, for instance, ships moor alongside the bank, a Geoflex sheet piles will not be damaged.

The great advantage of vinyl sheet piling compared to alternative building materials is the long service life combined with a solution that is friendly to the environment. In addition. vinyl is an inert material, which means that it does not dissolve when it comes into contact with most commonly occurring chemicals, and no polsonous substances are released into the ground or the water.

More and more oppostion has ansen to the application of hardwood in view of the threat to the tropical rain forests. With its harmful preservatives, wood impregnated with creosote or other chemical preservatives puts a burden on the environment, therefore,

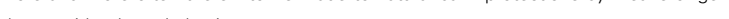

Installation

A Geoflex profile only weighs 3 to $5 \mathrm{~kg} / \mathrm{m}$, thus the weight of the $210 \mathrm{G}$ corrugated sheet amounts to only $11 \mathrm{~kg} / \mathrm{m}^{2}$. It is therefore very easy to handle, even in longer lengths. Sheets may be installed singly or en pairs

This gives the following advantages:

- Low ransport costs

- No heavy equipment required for installation

Geoflex can be installed by means of using a water jet system, free fall hammering, pneumatic hammer, and vibrator, or by pushing in with an excavator. At greater depths or ground with a high resistance, a steel guiding sheet pile is used. Geoflex can easily be combined or connected with other building materials. The sheets can be sawn or bored. Wood, concrete, steel or plastic can be used as cap and wale system. The system may be designed and used with ties and anchors as with tradional sheet piling systems.

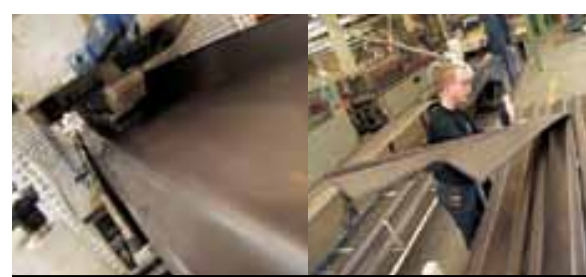

Geoflex

heet pile system

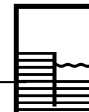

Geoflex technical specifications

Geoflex is a $250 \mathrm{~mm}$ wide vinyl extrusion profile. This means that the basic material is re melted and pressed through a mold. By doing so, a fixed profile is formed, which is cooled down and cut off to length. The process guarantees a consistent quality and

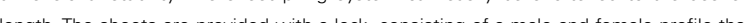
The The sheets a re prowdod

The lock has been designed with the following philosophy:

\section{Soil parts should not pass the lock.}

A certain rotalion or the lock, making curved shapes possible.

The variety of configurations give the designer the possibility to choose between two different sheet piling configurations with a large difference in flexural strength.

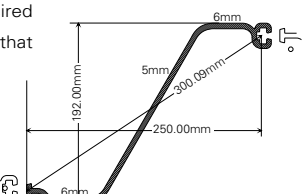

\begin{tabular}{|c|c|c|c|c|}
\hline & Unit & 2106 & 2100 & 420 \\
\hline $\begin{array}{l}\text { Weight } \\
\text { Profile height }\end{array}$ & $\begin{array}{l}\mathrm{kg} / \mathrm{m}^{2} \\
\mathrm{~mm}\end{array}$ & $\begin{array}{l}10,9 \\
95\end{array}$ & $\begin{array}{l}12,8 \\
192\end{array}$ & $\begin{array}{r}21 \\
210\end{array}$ \\
\hline Section modulus & $\mathrm{cm}^{3} / \mathrm{m}$ & 109 & 528 & 1041 \\
\hline Moment 50 year & $\mathrm{kNm} / \mathrm{m}$ & 2,4 & & 23 \\
\hline Max. soil retaining & $\frac{m}{m}$ & 0,7 & 1,5 & 2 \\
\hline
\end{tabular}

G GEOTECHNCS BV

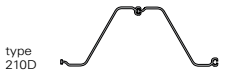

${ }_{2106}^{\text {type }}$

139

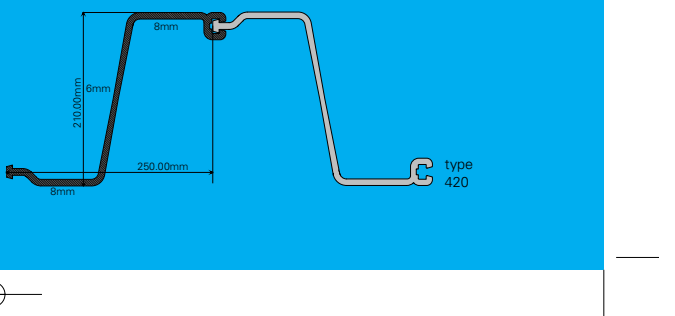




\section{NOTES:}

1. FLOODGATE MATERIAL TO BE ALUMINUM AS FOLLOWS

-GATE 5" X 2 1/2" X 1/8" EXTRUSIONS - GRADE 6005-T5 MIN. F 35 KSI

-GATE 2" X 2" X 1/4" TUBULAR - GRADE 6063 MIN F $=40 \mathrm{KSI}$

-PAN 1/4" SMOOTH PLATE - GRADE 5052 MIN $F_{Y}=30$ KSI

-FLAT BARS, STRUCTURAL ANGLES, HINGES - GRADE 6061-T6 MIN F = 40 KSI 2. HINGE BOLTS TO BE STAINLESS STEEL - GRADE 304, MIN $\mathrm{F}_{\mathrm{Y}}=90 \mathrm{KS}$

3. ALUMINUM TO BE WELDED WITH ALUMINUM WIRE - ER 4043 AWS A5.10 3/32

4. CONCRETE TO BE 4000 PSI MINIMUM 28 DAY STRENGTH.

5. REINFORCING BARS TO BE ASTM - A615 MIN FY $=60 \mathrm{KSI}$

6. ALL WELDS REOUIRED FOR STRUCTURAL STRENGTH OF THE GATE OR PAN ARE CALLED

OUT ON THESE DRAWINGS. ALL OTHER WELDING, NOT SHOWN OR CALLED OUT ON

THESE DRAWINGS, ARE ESSENTIALLY NON-STRUCTURAL WELDS OR WELDS WITH

NEGLIGIBLE LOADS AND RESULTING STRESSES. EXAMPLES OF SUCH WELDS ARE

AT SEAMS, SIDES, STIFFENERS AND TROUGH OF THE PAN, AND TRIM ANGLES

OF THE GATE. THESE WELDS ARE TO BE SELECTED BY THE FABRICATOR,

TAKING INTO CONSIDERATION ASSEMBLY, TRANSPORT AND CONTINUITY REQUIREMENTS, AND MUST BE APPROVED BY FLOODBREAK.

Floodbreak Floodgates

[From Floodbreak Website] Page 1 of 6. Vehicular Sample

Retrieved November 2010 from: http://www.floodbreak.com/?id=239
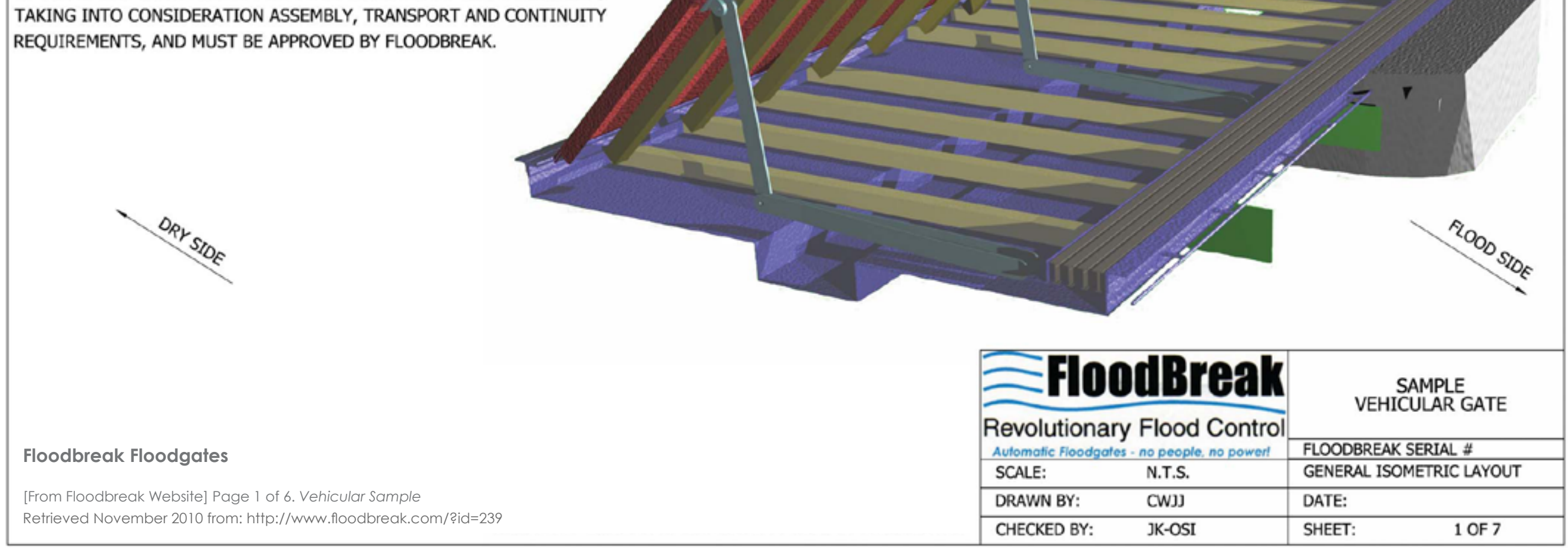

NOTE:

ALUMN. WIPER WALL EACH END NOT SHOWN FOR CLARITY PURPOSES. 


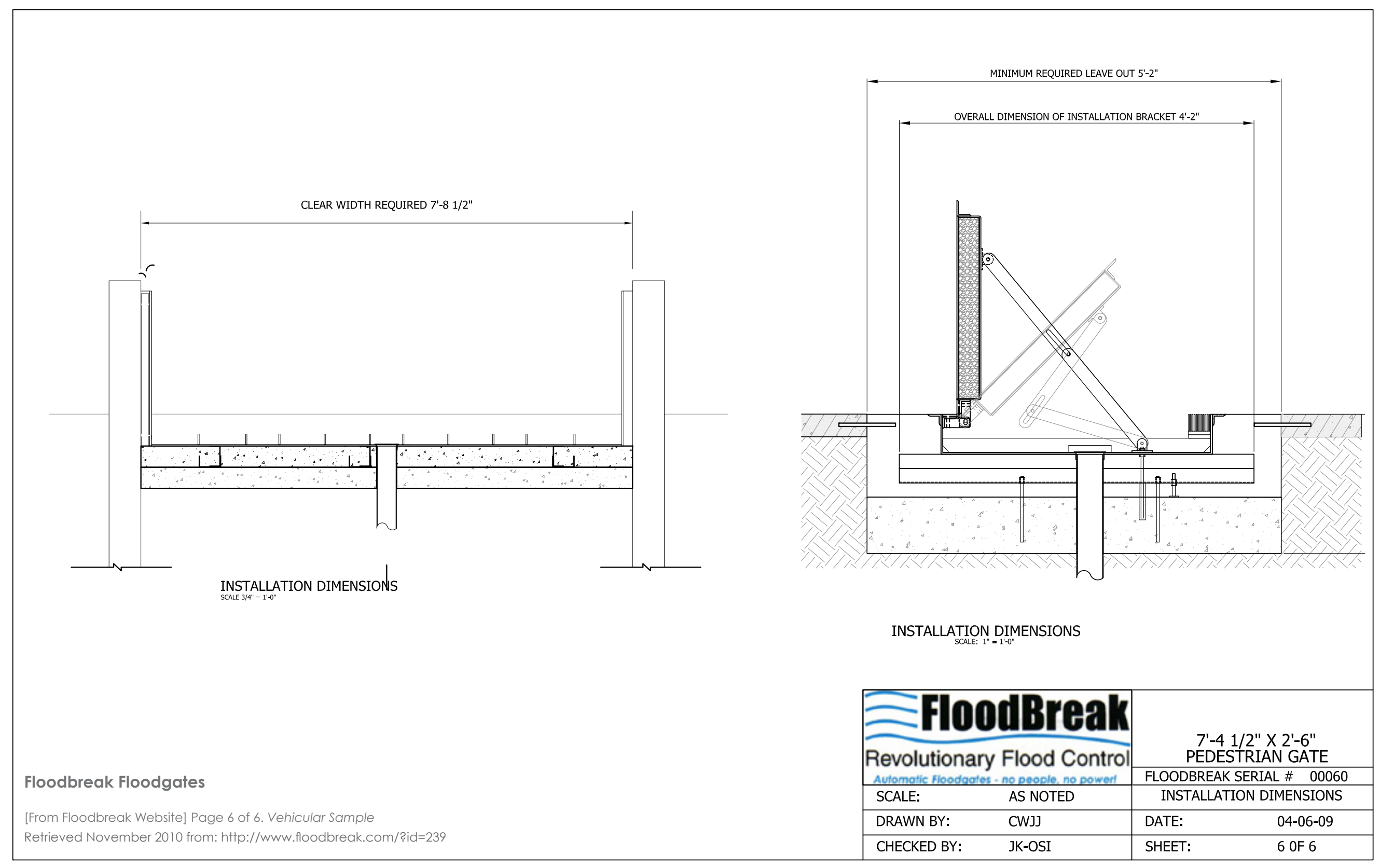

